UNIVERSIDADE DE SÃO PAULO

FACULDADE DE FILOSOFIA, LETRAS E CIÊNCIAS HUMANAS

DEPARTAMENTO DE LETRAS CLÁSSICAS E VERNÁCULAS

PROGRAMA DE PÓS-GRADUAÇÃO EM FILOLOGIA E LÍNGUA PORTUGUESA

A CONFIGURAÇAO DO DATIVO DE TERCEIRA PESSOA NO PORTUGUÊS DO BRASIL E NO PORTUGUÊS EUROPEU COM ENFOQUE NA FALA DO FORTALEZENSE CULTO 
UNIVERSIDADE DE SÃO PAULO

FACULDADE DE FILOSOFIA, LETRAS E CIÊNCIAS HUMANAS

DEPARTAMENTO DE LETRAS CLÁSSICAS E VERNÁCULAS

PROGRAMA DE PÓS-GRADUAÇÃO EM FILOLOGIA E LÍNGUA PORTUGUESA

\title{
A CONFIGURAÇAO DO DATIVO DE TERCEIRA PESSOA NO PORTUGUÊS DO BRASIL E NO PORTUGUÊS EUROPEU COM ENFOQUE NA FALA DO FORTALEZENSE CULTO
}

\author{
Maria Alves Maia Dantas
}

\begin{abstract}
Dissertação apresentada ao Programa de Pós-Graduação em Filologia e Língua Portuguesa, do Departamento de Letras Clássicas e Vernáculas da Faculdade de Filosofia, Letras e Ciências Humanas da Universidade de São Paulo, para obtenção do título de Mestre em Letras.
\end{abstract}

Orientadora: Prof. Dra. Maria Aparecida Correa Ribeiro Torres Morais

São Paulo

2007 


\section{Agradecimentos}

A meu esposo Altevi, que, esquecendo-se de si mesmo, fez-se presença generosa e constante, acompanhando ombro a ombro, passo a passo, as dificuldades e sucessos desta jornada.

À minha orientadora Prof. Dra. Maria Aparecida Correa Ribeiro Torres Morais, por ter acreditado em meu potencial e por sua orientação firme e precisa neste processo de crescimento humano e intelectual.

Aos professores que participaram da minha qualificação, em especial, à Prof. Dra. Márcia Oliveira, que contribuiu com este trabalho de forma significativa, através de suas valiosas sugestões.

À amiga Vera Tremel, que, incansável e generosa, tornou-se indispensável na organização deste trabalho.

Aos colegas de jornada Adilson, Adriana, Benjamim, Cássia, Daday, Érica e Tércio. 


\section{Dedicatória}

À memória da Professora Sula Leite, que entre arubus, sumitero e rescordar da minha infância, vislumbrou algo além, despertando em mim o encanto pela leitura, tornando possível o início desta caminhada.

A meus filhos queridos, Tiago e Aline, meu alento, minha fé, minha vibração mais profunda.

A todos aqueles que acreditam que navegar é preciso, mas sonhar também o é. 


\title{
Epígrafe
}

\author{
...A vida não me chegava pelos jornais nem pelos \\ livros \\ Vinha da boca do povo na língua errada do povo \\ Língua certa do povo \\ Porque ele é que fala gostoso o português do \\ Brasil \\ Ao passo que nós \\ O que fazemos \\ É macaquear \\ A sintaxe lusíada...
}

(Manuel Bandeira, Evocação do Recife, Rio de Janeiro, 1925) 


\section{Resumo}

Baseada em amostras (corpus) de língua oral do português brasileiro e europeu, este trabalho investiga as estratégias de substituição dos clíticos dativos de terceira pessoa no português do Brasil e no português europeu, bem como o uso de preposições introdutórias do dativo representado por sintagmas nominais. O objetivo é verificar as evidências de possível mudança paramétrica na variedade brasileira e evidenciar diferenças entre as alternativas utilizadas pelos falantes dos dois sistemas lingüísticos. Enfoca o uso dos complementos dativos de terceira pessoa em várias formas de representação na fala de nativos com grau superior de escolaridade (falante culto) da cidade de Fortaleza, Ceará (inquéritos do corpus Porcufort) e na fala de portugueses europeus (inquéritos do corpus CRPC), com verbos ditransitivos de transferência material e transferência verbal. Trabalhos científicos recentes indicam modificações no uso dos clíticos dativos de terceira pessoa na variedade do Brasil, distanciando-se do uso no português europeu. Os resultados sinalizam consideráveis diferenças entre as duas variedades: enquanto o português europeu faz largo uso dos clíticos dativo de terceira pessoa, no português do Brasil verifica-se sua substituição por estratégias alternativas como o uso de pronomes tônicos anafóricos, ou mesmo do objeto nulo. Os dados estudados na pesquisa apontam para a confirmação da hipótese de Galves (2001) de que competências gramaticais do PE e do PB são diferentes e tendem a distanciar-se na fala cotidiana. Verificou-se também que o PB não possui as construções de núcleo aplicativo realizadas no PE, conforme demonstrado na proposta de Torres Morais (2007) em que se evidencia que, no PE, o argumento interno dativo de verbos de transferência material e verbal é licenciado por um núcleo aplicativo que se realiza mediante a presença obrigatória da preposição $a$, marcador de Caso dativo. O PB perdeu a capacidade de realizar esse dativo, pois seus complementos verbais são introduzidos por preposições lexicais, o que impossibilita as construções de núcleo aplicativo com a configuração verificada no $\mathrm{PE}$, mas o PB apresenta outra forma de configurá-lo: as construções de objeto duplo.

Palavras-chave: Dativos de terceira pessoa, Português brasileiro, Português europeu, clíticos, núcleo aplicativo 


\begin{abstract}
Based in samples (corpus) of verbal language of the Brazilian and European Portuguese, this work investigates the strategies of substitution of the 3rd. person dative clitics in the Brazilian Portuguese and the European Portuguese, as well as the use of introductory prepositions of the dative represented for lexical DP. The objective is to verify the evidences of possible parametric change in the Brazilian variety and to evidence the differences between the alternatives used for the talkers of the two linguistic systems. It focuses the use of the 3rd. person dative clitics complements in several forms of representation in the speech of natives with superior degree (cult talker) of the city of Fortaleza, Ceará (inquiries of the Porcufort corpus) and in speaks of European Portugueses (inquiries of corpus CRPC), with ditransitive verbs of concrete transference and conceptual transference. Recent scientific trials indicate modifications in the use of the appointed 3rd. person dative clitics in the variety of Brazil, is separating itself from the European one.The results pointed to considerable differences between the two varieties: while the European Portuguese uses of the 3rd. person dative clitics, in the Brazilian Portuguese is possible to verify its substitution for alternative strategies as the use of anaphoric strong pronouns, or the null object. The data studied in this work point out to the confirmation of the hypothesis of Galves (2001) of that grammatical abilities of the European Portuguese and the Brazilian Portuguese are different and tend to become more distant themselves in speak speech. It was also verified that the Brazilian Portuguese does not have constructions of applicative head of the European Portuguese, as demonstrated in the proposal of Torres Morais (2007) which evidences that, in the European Portuguese, the internal appointed argument of concrete and cognitive transference is permitted by a applicative head that carries through by means of the obligator presence of the preposition "a", marking of dative case marker. The Brazilian Portuguese lost the capacity to carry through this dative, therefore its verbal complements are introduced by lexical prepositions, that means they don't realize the applicative head with the configuration verified in the European Portuguese, but they have another form to configure it: double object constructions
\end{abstract}

Keywords: Dative, Brazilian Portuguese, European Portuguese, applicative head, clitics. 



\section{Relação de gráficos}

Página

Gráfico 1 Ocorrências do clítico pronominal e lexias verbais nas duas variedades do português - modalidade oral

Gráfico 2 Distribuição percentual do clítico pronominal e lexias verbais nas duas variedades do português - modalidade oral

Gráfico 3 Ocorrências de dativos com verbos de transferência material e verbal

Gráfico 4 Ocorrências de dativos com verbos de transferência material e verbal, por tipo de dativo

Gráfico 5 Distribuição percentual de dativos com verbos de transferência material e verbal, por tipo de dativo

Gráfico 6 Distribuição percentual de variantes do argumento dativo de terceira pessoa no Português brasileiro dos séc. XVIII e séc. XIX (cf. Berlinck 2001)

Gráfico 7 Ocorrências e Distribuição percentual do dativo nulo, com verbos de transferência material, por tipo de sentença

Gráfico 8 Ocorrências do dativo nulo com verbos de transferência verbal

Gráfico 9 Distribuição do clítico dativo com verbos de transferência material, por tipo de oração

Gráfico 10 Distribuição do clítico dativo com verbos de transferência verbal, por tipo de oração

Gráfico 11 Ocorrências de sintagmas nominais (com para, com a e sem preposição) com verbos de transferência material, segundo tipo de oração

Gráfico 12 Distribuição percentual dos sintagmas nominais com verbos de transferência material, por tipo de oração

Gráfico 13 Distribuição dos sintagmas nominais com verbos de transferência verbal (com para, com a e sem preposição)

Gráfico 14 Distribuição dos sintagmas nominais com verbos de transferência verbal, com a preposição a e sem preposição 
Gráfico 15 Distribuição percentual de dativos com sintagmas nominais, com verbos de transferência verbal, por tipo de oração

Gráfico 16 Preposição de complementos de verbos do tipo dar (PEUL)

Gráfico 170corrências com dativos representados por pronomes anafóricos preposicionados, com verbos de transferência material, realizado com para, com a e sem preposição, por tipo de oração

Gráfico 18 Ocorrências com dativos realizados com pronomes anafóricos, com verbos de transferência material, segundo tipo de oração, usado com para, com a ou sem preposição

Gráfico 19 Distribuição percentual de dativos representados por pronomes anafóricos, com verbos de transferência material, por tipo de preposição, segundo tipo de oração

Gráfico 20 Ocorrências de dativos representados por pronomes anafóricos, com verbos de transferência verbal, realizados com a preposição para e preposição $a$, por tipo de oração

Gráfico 21 Ocorrências de dativos realizados com pronomes anafóricos, com verbos de transferência verbal, por tipo de preposição, segundo tipo de oração

Gráfico 22 Distribuição percentual de dativos realizados por pronomes anafóricos com verbos de transferência verbal, por tipo de preposição e tipo de oração

Gráfico 23 Ocorrências do clítico Ihe em relação às pessoas do discurso, com verbos de transferência material e verbal

Gráfico 24 Distribuição percentual do clitico the em relação às pessoas do discurso, com verbos de transferência material e verbal

Gráfico 25 Objeto indireto anafórico na fala de jovens curitibanos (cf. Berlinck, 1997)

Gráfico 26 Distribuição percentual de dativos nulos, clíticos e anafóricos preposicionados de terceira pessoa

Gráfico 27 Ocorrências de colocação do clítico dativo lhe, com relação ao verbo, no Português do Brasil

Gráfico 28 Ordem do clítico pronominal em lexias verbais simples nas duas variedades do Português (modalidade oral) 
Gráfico 29 Total de ocorrências dos complementos dativos encontrados no CRPC

Gráfico 30 Distribuição percentual dos complementos dativos encontrados no CRPC

Gráfico 31 Ocorrências de dativos encontrados no CRPC com verbos de transferência material e verbal

Gráfico 32 Distribuição percentual de dativos encontrados no CRPC com verbos de transferência material e verbal

Gráfico 33 Ocorrências de dativos nulos encontrados no CRPC, com verbos de transferência material e verbal segundo o tipo de oração

Gráfico 34 Distribuição percentual de dativos nulos encontrados no CRPC, com verbos de transferência material e verbal segundo o tipo de oração

Gráfico 35 Ocorrências de sintagmas nominais encontrados no CRPC com verbos de transferência material, segundo o uso da preposição para e preposição $a$, por tipo de oração

Gráfico 36 Distribuição percentual de de sintagmas nominais encontrados no CRPC com verbos de transferência material, segundo o uso da preposição para e preposição a, por tipo de oração

Gráfico 37 Ocorrências de sintagmas nominais encontrados no CRPC com verbos de transferência verbal, segundo o uso da preposição para e preposição $a$, por tipo de oração

Gráfico 38 Distribuição percentual de sintagmas nominais encontrados no CRPC com verbos de transferência verbal, segundo o uso da preposição para e preposição $a$, por tipo de oração

Gráfico 39 Ocorrência do clítico dativo the em relação às pessoas do discurso com verbos de transferência material e verbal

Gráfico 40 Distribuição percentual do clítico dativo Ihe em relação às pessoas do discurso com verbos de transferência material e verbal

Gráfico 41 Colocação do clítico dativo Ihe com relação ao verbo, no CRPC

Gráfico 42 Distribuição percentual da colocação do clítico dativo the com relação ao verbo, no CRPC 
Tabela 1 Pronomes pessoais retos e oblíquos (Bechara) 17

Tabela 2 Pronomes pessoais retos e oblíquos (cf. Mateus et al., 2003) $\quad \mathbf{3 0}$

Tabela 3 Pronomes pessoais clíticos (cf. Mateus et al., 2003) 30

Tabela 4 Sistema pronominal: realizações de falantes de PB (cf. Torres Morais e Salles, 2007)

Tabela 5 Ocorrências de dativos com verbos de transferência material e verbal, por tipo de dativo

Tabela 6 Ocorrências de dativos nulos com verbos de transferência material, por tipo de oração

Tabela 7 Ocorrências de dativos nulos com verbos de transferência verbal, por tipo de oração

Tabela 8 Ocorrências do clítico dativo com verbos de transferência material, por tipo de oração

Tabela 9 Ocorrências do clítico dativo com verbos de transferência verbal, por tipo de oração

Tabela 10 Ocorrências de sintagmas preposicional e nominal com verbos de transferência material com para, com a e sem preposição, segundo o tipo de oração

Tabela 11 Ocorrências de sintagmas nominais com verbos de transferência verbal, segundo a preposição e tipo de oração

Tabela 12 Ocorrências e distribuição percentual de dativos realizados por pronomes anafóricos tônicos com verbos de transferência material, com a preposição para, com a preposição a e sem preposição, por tipo de oração

Tabela 13 Ocorrências de dativos realizados com pronomes tônicos anafóricos com verbos de transferência verbal, com a preposição para e com a preposição a, por tipo de oração

Tabela 14 Ocorrências do uso do clítico Ihe em relação às pessoas do discurso, com verbos de transferência material e verbal

Tabela 15 Ocorrências da colocação do clítico dativo Ihe, em relação ao verbo, no Português do Brasil 
Tabela 16 Ocorrências de dativos encontrados no CRPC, com verbos de transferência material e verbal, por tipo de dativo

Tabela 17 Distribuição percentual de dativos encontrados no CRPC, com verbos de transferência material e verbal, por tipo de dativo

Tabela 18 Ocorrências de dativos nulos encontrados no CRPC, com verbos de transferência material e verbal, segundo o tipo de oração

Tabela 19 Distribuição percentual de dativos nulos encontrados no CRPC, com verbos de transferência material e verbal, segundo o tipo de oração

Tabela 20 Ocorrências de sintagmas nominais encontrados no CRPC, com verbos de transferência material, com preposição para e preposição $a$, segundo o tipo de oração

153

Tabela 21 Distribuição percentual de sintagmas nominais encontrados no CRPC, com verbos de transferência material, com preposição_para e preposição $a$, segundo o tipo de oração

Tabela 22 Ocorrências de sintagmas nominais encontrados no CRPC, com verbos de transferência verbal, com preposição para e preposição $a$, segundo o tipo de oração

Tabela 23 Distribuição percentual de sintagmas nominais encontrados no CRPC, com verbos de transferência verbal, com preposição para e preposição $a$, segundo o tipo de oração

Tabela 24 Ocorrências do clítico dativo Ihe encontrados no CRPC, em relação às pessoas do discurso, com verbos de transferência material e verbal

163

Tabela 25 Distribuição percentual do clítico dativo the encontrados no CRPC, em relação às pessoas do discurso, com verbos de transferência material e verbal

Tabela 26 Colocação do clítico dativo Ihe, com relação ao verbo, no CRPC

Tabela 27 Distribuição percentual da colocação do clítico dativo Ihe, com relação ao verbo, no CRPC 


\section{SUMÁRIO}

INTRODUÇÃO

1.1 Língua falada e língua escrita: duas dinâmicas

1.2 Posicionamento das gramáticas normativas e prescritivas do PB em relação ao Objeto Indireto e aos pronomes pessoais

1.2.1 O Objeto Indireto e os pronomes pessoais retos e oblíquos em Bechara

1.2.2 O Objeto Indireto e os pronomes pessoais retos e oblíquos em Cunha \& Cintra

1.2.3 O Objeto Indireto os pronomes pessoais retos e oblíquos em Rocha Lima

1.3 Posicionamento das gramáticas descritivas do PB e do PE em relação ao Objeto Indireto e aos pronomes pessoais retos e oblíquos

1.3.1 O Objeto Indireto e os pronomes pessoais retos

e oblíquos em Neves

1.3.2 O Objeto Indireto e os pronomes pessoais retos e oblíquos em Mateus et al.

1.4 Algumas considerações sobre os aspectos gramaticais estudados 33

1.5 A gramática sob novas perspectivas 35

1.5.1 As realizações de complementos com verbos ditransitivos $\quad 36$

1.5.2 Inovações no sistema pronominal do PB 37

1.5.3 Próclise e ênclise no PB e no PE 39 
2.10 enfoque gerativista 45

2.20 enfoque da Sociolingüística variacionista 54

2.3 Esclarecimento sobre as hipóteses 56

2.3.1 A formulação teórica do núcleo aplicativo 56

2.3.2 Hipóteses de trabalho $\quad 65$

2.4 Tratamento metodológico 68

CAPÍTULO 3 - INTERPRETAÇÃO E ANÁLISE DOS INQUÉRITOS DO PORCUFORT 74

3.1 Apresentação e caracterização do Corpus Português Oral Culto de Fortaleza (PORCUFORT)

3.2 Exemplos de Objetos Indiretos realizados por falantes do PB (PORCUFORT)

3.3 Descrição e análise das ocorrências do PORCUFORT referentes aos objetos indiretos em suas várias formas de representação

3.3.1 As várias formas de representação do Objeto Indireto com verbos de transferência material e verbal

3.3.2 Objetos Indiretos nulos com verbos de transferência material

3.3.3 Objetos Indiretos nulos com verbos de transferência verbal

3.3.4 Clítico Objeto Indireto com verbos de transferência material $\quad 88$

3.3.5 Clítico Objeto Indireto com verbos de transferência verbal $\quad 90$

3.3.6 Objetos Indiretos Sintagmas Nominais preposicionados com verbos de transferência material

3.3.7 Objetos Indiretos Sintagmas Nominais preposicionados com verbos de transferência verbal

3.3.8 Objetos Indiretos Pronomes Anafóricos preposicionados com verbos de transferência material 
3.3.9 Objetos Indiretos Pronomes Anafóricos preposicionados com verbos de transferência verbal 110

3.3.10 Uso do Ihe em relação às pessoas do discurso 113

3.3.11 Colocação do clítico Ihe em relação aos verbos 119

3.4 Realizações sintáticas que merecem destaque (PORCUFORT) 124

3.4.1 O pronome ele como acusativo 124

3.4.2 O uso do pronome Ihe como objeto direto: O leísmo brasileiro 127

3.4.3 As construções de objeto duplo (Double Object Constructions) 130

CAPÍTULO 4 - INTERPRETAÇÃO E ANÁLISE DOS INQUÉRITOS DO CRPC

4.1 Apresentação do CORPUS DE REFERÊNCIA DO PORTUGUÊS CONTEMPORÂNEO (CRPC) e justificativa de sua escolha 138

4.2 Complementos dativos no CRPC e construções paralelas 140

4.2.1 Exemplos de complementos dativos no CRPC 141

4.2.2 Realizações de complementos verbais com a preposição para e outras ocorrências do CRPC

4.3 Descrição e análise das ocorrências do CRPC referentes aos complementos dativos em suas várias formas de representação

4.3.1 Complementos dativos em todas as suas formas de representação com verbos de transferência material e de transferência verbal

4.3.2 Complementos dativos nulos com verbos de transferência material e verbal 
4.3.3 Complementos dativos sintagmas nominais com verbos

de transferência material

4.3.4 Complementos dativos sintagmas nominais com verbos de transferência verbal

4.3.5 Complementos dativos com pronomes anafóricos tônicos preposicionados com verbos de transferência material

4.3.6 Clíticos dativos com verbos de transferência material e verbal 163

4.3.7 Ocorrências de colocação do clítico dativo lhe em relação aos verbos 


\section{INTRODUÇÃO}

O universo de trabalho de quem se propõe a estudar lingüística é bombardeado constantemente por expressões como reanálise, mudança paramétrica, afixos, on set, preposição dummy, gramaticalização, lexicalização, argumento, grade temática, papéis temáticos, predicados, núcleos, núcleo aplicativo, etc.etc.etc. Dar conta de toda essa nomenclatura, compreendê-la e tentar aplicá-la (no que couber) ao contexto lingüístico objeto de estudo não é tarefa muito fácil.

$\mathrm{O}$ assunto que pesquisamos - $\mathrm{o}$ dativo de terceira pessoa em todas as suas formas de realização não é algo inédito. É possível que a novidade seja o objeto de nosso estudo: a fala do fortalezense culto, representativa do uso urbano do Português falado no Brasil (PB) em oposição ao Português europeu (PE). Um dos focos desta pesquisa, o PORCUFORT (Português Oral Culto de Fortaleza) não foi contemplado em estudos lingüísticos anteriores, uma vez que as pesquisas em corpus de língua oral culta, até agora, concentraram-se nos dados das cinco capitais incluídas no conhecido projeto norma urbana culta (NURC), a saber: Rio de Janeiro, São Paulo, Salvador, Recife e Porto Alegre).

O que se observa em relação ao dativo de terceira pessoa na fala culta de Fortaleza, representativa de um português brasileiro culto em relação ao português europeu culto é que existe uma grande distância entre as realizações lingüísticas nas duas variedades do Português, distância essa que corrobora a hipótese de Galves (2001, p 13-14) de que a competência gramatical do falante de PE é diferente da competência gramatical do falante de PB.

Este trabalho tem como objetivos:

a) Estudar o uso do objeto indireto de terceira pessoa em verbos ditransitivos no PORCUFORT e na parte de inquéritos orais espontâneos do Corpus de Referência do Português Contemporâneo (CRPC), particularmente nos aspectos abaixo: 
- as preposições que introduzem tais complementos em PB e em PE;

- uso do clítico Ihe(s) nos dois corpora, atentando para a sua colocação;

b) Comparar os aspectos acima mencionados nos dois corpora, no sentido de confrontar os resultados com estudos já realizados sobre o tema;

c) Investigar a ocorrência de algumas peculiaridades relevantes no PB (os pronomes ele e the, na função de objeto direto), e o objeto indireto introduzido sem o auxílio de preposição.

Para alcançar tais objetivos, o desenvolvimento da pesquisa foi integralmente pautado em inquéritos que integram o Português Oral Culto de Fortaleza (PORCUFORT), por nós denominado PBF e a parte oral do Corpus de Referência do Português Contemporâneo (CRPC), descritos e analisados nos capítulos 3 e 4, respectivamente. Neles, foram selecionadas todas as sentenças que contêm objetos indiretos de terceira pessoa com verbos ditransitivos, representados pelas seguintes variáveis: objeto indireto complemento lexical; objeto indireto nulo; objeto indireto anafórico tônico preposicionado e objeto indireto clítico.

Vale esclarecer que os complementos lexicais abordados neste estudo não se referem a estratégias de substituição de clíticos. Como um dos nossos propósitos é investigar o tipo de preposição que introduz tais complementos, não nos limitamos aos que poderiam ser usados como as estratégias referidas.

Esta dissertação está estruturada de forma assimétrica, assim é que alguns capítulos apresentam-se muito longos e outros bastante breves. Tal disparidade justifica-se por conta de os capítulos com apresentação e descrição dos corpora conter muitas tabela e gráficos que ocasionam essas desproporções. 
Vale ressaltar que, antes de cada capítulo, apresentamos uma breve introdução, que deverá servir como fio condutor do capítulo e ao final, fechamos o capítulo com uma ligeira conclusão.

O primeiro capítulo versa sobre fala, mudança e norma; são considerados neste capítulo, alguns fatos relativos não só à fala em oposição à norma, mas também a alguns textos escritos; evidencia-se também, o tratamento que algumas gramáticas normativas tradicionais, dão ao assunto, com comentários e exemplos retirados dessas gramáticas. Também são mencionados autores que não tiveram a preocupação de descrever normas para a língua, mas ativeram-se à descrição das realizações, ou seja, basearam-se no uso efetivo da língua, tanto no PB como no PE.

Como contraponto, ainda no primeiro capítulo, apresentam-se observações sobre o trabalho de estudiosos que se detiveram nos aspectos do uso da língua através das realizações da fala, tanto em PB como em PE, enfocando o dativo em todas as suas formas de realização, com base em estudo de corpora específicos. Apresentam-se, em seguida, considerações sobre as diferentes posições dos lingüistas mencionados.

O segundo capítulo, que se intitula Fundamentação teórica e descrição metodológica, trata das teorias que dão suporte à pesquisa. Nele são referidos alguns fundamentos do gerativismo e algumas observações sobre a sociolingüística variacionista. Apresenta-se também a proposta formulada por Torres Morais (2006) a respeito da realização do núcleo aplicativo no PE, na qual se fundamentam as nossas hipóteses de estudo em relação às construções com dativos tanto no PE como no PB. Para maior clareza, introduzimos ligeiro histórico sobre o núcleo aplicativo, com o objetivo de situar o leitor, uma vez que tal proposta é nova, tendo sido referida pela primeira vez em relação ao $\mathrm{PE}$.

O segundo capítulo apresenta ainda as hipóteses que levantamos em relação ao estudo comparativo entre o PE e o PB, tendo como base os objetivos propostos. 
Inicia-se o terceiro capítulo com a descrição do PORCUFORT. Neste capítulo, apresentamos a interpretação e análise dos gráficos desse corpus, considerando as variáveis e os contextos lingüísticos das suas ocorrências, situações ilustradas por tabelas e gráficos, com a finalidade de conferir maior clareza ao assunto.

Um dos principais focos da nossa pesquisa para esta dissertação foi verificar, por meio de 'sentenças' realizadas por falantes da capital cearense, considerados como falantes de uma variante culta, se é possível confirmar de forma categórica, a idéia de que o Português Oral Culto de Fortaleza está consolidando um processo de mudança, no que se refere ao uso do clítico dativo de terceira pessoa. Para isso, utilizamos a transcrição de um número considerável de sentenças, não só em relação ao clítico, mas também a outros fenômenos lingüísticos objeto deste estudo, a fim de garantir maior precisão na análise.

Além disso, buscou-se também averiguar como é a ocorrência da preposição que introduz o objeto indireto no PBF considerando o que acontece no PB, de maneira geral, em que a variante para está em competição com a variante a na introdução de tal objeto, sinalizando para uma possível extinção dos complementos dativos no PB, conforme referido por Torres Morais e Berlinck (2004).

Outro fato estudado no capítulo 3 , no que tange à realização dos complementos verbais, refere-se à investigação de inovações, já detectadas e estudadas em outras regiões do Brasil: ele e the na função de objeto direto, bem como as construções de objeto duplo (DOC) ${ }^{1}$ já detectadas por Scher (1996) em estudos realizados com falantes da Zona da Mata Mineira e referidas por Torres Morais e Salles (2007).

O quarto capítulo trata do estudo do Corpus de Referência do Português Contemporâneo (CRPC), modalidade oral, com o mesmo enfoque do PBF, considerando as mesmas variáveis lingüísticas, culminando com a interpretação e análise dos gráficos. Ainda no quarto capítulo, são confrontados os dados dos dois corpora, com vistas a confirmar as hipóteses levantadas.

\footnotetext{
${ }^{1}$ Double Object Constructions.
} 
Esse capítulo, assim como o anterior, apresenta muitas sentenças realizadas pelos falantes do PE. O grande número de sentenças apresentadas, da mesma forma que no capítulo anterior, justifica-se pela necessidade de verificar com maior exatidão os fenômenos a que nos propusemos estudar. Atentamos, então, para as realizações dos clíticos, acentuando aquelas realizadas por falantes sem nenhuma escolaridade, cujo propósito é verificar se tais clíticos fazem parte da competência lingüística de tais falantes.

Verificamos também algumas realizações do PE que apresentam a ocorrência do núcleo aplicativo, um dos embasamentos teóricos da nossa pesquisa, conforme já referido. Nesse aspecto nos voltamos para o estudo da preposição introdutora dos complementos dativos, atentando para algumas realizações de preposições lexicais que acenariam para a alternância dativa do PE, com a realização das ditransitivas preposicionadas. Observamos ainda a realização do núcleo aplicativo no PE com o redobro do clítico.

Tanto no terceiro como no quarto capítulo verificamos a colocação pronominal dos clíticos, realizando algumas comparações entre os dois corpora em relação ao assunto.

$\mathrm{Na}$ conclusão final, voltamos às nossas hipóteses, apresentando, a partir dos resultados verificados, a confirmação daquilo que esperávamos em relação aos assuntos estudados. 


\section{CAPÍTULO 1 - A FALA, A MUDANÇA E A NORMA}

Neste capítulo, tecemos algumas considerações sobre a importância da fala no fenômeno da mudança lingüística, enfatizando o distanciamento entre as prescrições da norma a as realizações da fala; destacam-se as dinâmicas que se evidenciam na fala e na escrita, bem como a postura dos gramáticos do PB e do PE sobre os assuntos discutidos neste trabalho.

Traçamos um paralelo entre o que preconiza a gramática normativa e as realizações de falas, tomando por base as modificações evidenciadas no sistema pronominal do PB. Realizamos também algumas comparações entre o PB de Fortaleza, principalmente no que se refere ao uso dos clíticos dativos de terceira pessoa e à sua colocação em relação ao verbo, tendo em vista que tais realizações evidenciam o distanciamento entre a fala e o que preconizam os nossos gramáticos, centrados na norma culta lusitana, pouco considerando as inovações brasileiras, mesmos as mais aceitas e realizadas por falantes de todos os níveis. A colocação dos clíticos, além disso, é uma das principais diferenças observadas nas realizações do PE e do PB.

O surgimento de várias propostas de estudo da Lingüística e o aprofundamento no estudo dessa ciência ensejaram a que se considerasse a fala como elemento crucial no processo da variação e da mudança lingüística. Para alguns autores, o fenômeno da variação traz contribuição essencial para se compreender a inovação lingüística. O que se pode perceber, desta forma, é que estudiosos das diversas correntes de estudos da linguagem - sociolingüistas variacionistas, psicolingüistas, funcionalistas, gerativistas, entre outros - aceitam a mudança lingüística, divergindo apenas na forma de encarar e explicar tal fenômeno, como se pode verificar pelos comentários de Mollica \& Roncarati (2001, p.45-55):

"Vale esclarecer que, ao localizar a variação e a mudança no indivíduo, alguns paradigmas teóricos partem de pressupostos diferentes. De um lado, acredita-se que os falantes e seus perfis sociolingüísticos reais ou desejados reforçam e/ou são responsáveis por inovações. De outro, certos modelos formais 
costumam responsabilizar as crianças como agentes propulsores de inovações, ao fazerem suas escolhas ao longo do processo de construção de suas gramáticas. De uma ótica mais propriamente gerativista, oferece-se uma contribuição à construção de paradigma de mudança sob perspectiva diferenciada".

\subsection{Língua falada e língua escrita: duas dinâmicas}

Não foi em vão que estudos lingüísticos anteriores do Português brasileiro, centrados (até por questões de ordem prática) exclusivamente na língua escrita, foram aos poucos cedendo espaço para estudos da fala ${ }^{2}$. Esse tipo de enfoque, valorizado hoje, teve lugar, entre nós, desde o início do século passado. Entre seus estudiosos, destaca-se a figura de Mario Marroquim que, em seu livro "Língua do Nordeste" (1945, p.15), demonstra uma posição inovadora sobre o assunto ao afirmar:

Contra a opinião dos que negam o dialeto brasileiro, opinião que vai de encontro a tudo que está estabelecido em relação à evolução das línguas, se.opõe a realidade que não exige demonstração. (...) É um fenômeno cuja espontaneidade não podemos deter nem governar, é uma força viva que surge das massas populares ao impulso das tendências lógicas e naturais e cuja expansão devemos estudar, mas não está em nós orientar, porque ela se dirige de acordo com leis glóticas certas e imutáveis.

Ao prefaciar o referido livro de Marroquim, Gilberto Freire afirma:

[...] trata-se antes de tudo, de uma autêntica pesquisa de campo; de um livro de quem estudou a língua portuguesa, não apenas nas páginas dos livros eruditos e dos tratados acadêmicos, mas entre os homens.

Com base ainda na obra do autor, é de se notar que a mudança lingüística é deveras demorada, tanto na sua realização propriamente dita, como no seu reconhecimento oficial. No livro $A$ Língua do Nordeste, escrito há mais de 70 anos,

\footnotetext{
${ }^{2}$ É certo que ainda existem muitos estudos embasados na escrita, sobretudo em cartas pessoais, anúncios de jornais e peças de teatro e até em livros da atualidade, que visam, sobretudo, ao acompanhamento das variações através dos tempos ou da forma como tais variações estão sendo encaradas no texto escrito..
} 
Marroquim (1945) defende o uso da forma verbal ter em substituição a haver ${ }^{3}$, mas tal uso continua sendo uma forma marginal em textos escritos, especialmente os mais formais, mesmo após ter sido empregada por poetas de peso como Carlos Drummond de Andrade e Manuel Bandeira.

Em (1), no poema intitulado "No meio do caminho", Drummond (1974, p.12) faz uso de ter por haver

(1) "No meio do caminho tinha uma pedra/ tinha uma pedra no meio do caminho tinha uma pedra no meio do caminho tinha uma pedra" .

Em (2), Bandeira (1970, p.331) alterna o uso de ter e haver em seu poema "Oração a Santa Teresa":

(2) "Na estação tinha uma casa de frutas

Onde o chefe da família

Podia comprar a quarta de manteiga de sal

A lata de biscoito aimoré

A língua do rio grande

O homem das balas recebia recados, guardava embrulhos

De vez em quando havia um desastre na manobra do reboque

Bom tempo em que havia desastre na manobra do reboque!"

Gramáticos normativos, de reconhecida contribuição, como Bechara e Cunha, fazem referência a tal uso, citando também Drummond e Bandeira. Bechara (2003) menciona a questão do uso de verbo ter por haver sob o título "Erro no emprego do verbo TER por HAVER":

"Constitui incorreção, na língua culta, o emprego do verbo ter em lugar de haver em orações como:

Tem livros na mesa por Há livros na mesa.

\footnotetext{
${ }^{3} \mathrm{O}$ verbo haver no sentido de existir, é impessoal, ou seja, é usado na terceira pessoa do singular nas chamadas orações sem sujeito, segundo a gramática tradicional (G.T.) No PB, o verbo ter passou a ser usado com a mesma acepção. Para Mateus et al. (2003, p.302), tal verbo "constitui um caso excepcional transligüisticamente, uma vez que seleciona uma argumento interno objecto directo, marcado com o Caso acusativo, sem selecionar uma argumento externo. Ou seja, nem é um verbo de zero lugares ( sic) nem um verbo inacusativo".
} 
Este emprego corre vitorioso na conversação de todos os momentos e já vai ganhando aceitação nos escritores modernos brasileiros que procuram aproximar a língua escrita da espontaneidade do falar coloquial:

Na Rua Toneleros tem um bosque, que se chama, que se chama solidão". (Bandeira, M. Poesia e prosa, II, p.419, citado por Bechara, 2005, p.39)

Por sua vez, Cunha e Cintra (2001) também aludem ao assunto, destacando o uso coloquial da variante:

"Na linguagem coloquial do Brasil é corrente o emprego do verbo ter como impessoal, à semelhança de haver. Escritores modernos - e alguns dos maiores - não têm dúvida em alçar a construção à língua literária.

Comparem-se estes passos:

Hoje tem festa no brejo! (Drummond de Andrade, C., citado por Cunha, 2001, p.131-2).

Em Pasárgada tem tudo,

É outra civilização... (Bandeira, M. p.222, citado por Cunha, 2001, p.131-2).

Em relação à colocação pronominal, um dos focos do nosso trabalho, Bandeira (1970, p.114) e Drummond (1974, p.21) revelam-se também inovadores, até porque a corrente modernista, de que esses poetas participaram, fazia a apologia da brasilidade, defendendo a incorporação da fala brasileira à literatura, fazendo um rechaço ao emprego das formas lusitanas, como se observa nos versos de Bandeira em Evocação do Recife, transcritos abaixo:

(3) Me lembro de todos os pregões:

Ovos frescos e baratos

Dez ovos por uma pataca

Foi há muito tempo...

A vida não me chegava pelos jornais nem pelos livros

Vinha da boca do povo na língua errada do povo

Língua certa do povo

Porque ele é que fala gostoso o português do Brasil

Ao passo que nós

O que fazemos

É macaquear

A sintaxe lusíada

Drummond também usa essa colocação pronominal bem brasileira: 
(4)

Uma coisa triste no fundo da sala

Me disseram que era Chopin.

Em Considerações do Poema, Drummond (1974, p.75) também usa a próclise em início de oração:

(5) As palavras não nascem amarradas, elas saltam, se beijam, se dissolvem, no céu livre por vezes um desenho, são puras, largas, autênticas, indevassáveis.

O uso do verbo ter com sentido de haver, bem como o uso dos pronomes oblíquos átonos em início de oração são variantes que já se expandiram por vários segmentos sociais e podem ser observadas na fala cotidiana, tanto de gente simples quanto no discurso oral de pessoas com alto grau de escolaridade.

É de se notar, portanto, que a alta produtividade de uma variante não significa necessariamente mudança, pelo menos em termos oficiais. Assim, a língua falada corre célere com suas inovações por um lado, enquanto, por sua vez, a aceitação oficial das variantes anda a "passo de tartaruga".

Vemos, portanto, que a gramática da língua escrita, apresenta uma dinâmica um pouco diferente da gramática da língua falada, embora tal modalidade apresente também inovações e mudanças. Torres Morais e Ribeiro tecem as seguintes considerações a respeito de tal binômio:

A gramática da língua escrita apresenta, no entanto, uma dinâmica um pouco diferente da gramática da língua falada, embora tal modalidade apresente também inovações e mudanças. Torres Morais e Ribeiro (2005, p.31-32). tecem as seguintes considerações a respeito de tal binômio:

É um fato lingüístico comum, observado em maior ou menor grau nas diversas línguas particulares, o distanciamento entre a forma da gramática da língua falada e a forma da gramática da língua escrita, principalmente a dos textos mais formais, que revelam influência marcante dos padrões normativos, comumente assimilados durante anos de ensino escolar sistemático. Além disso, a escrita é mais conservadora e tem objetivos específicos que a particularizam em relação à fala. Um desses objetivos, que sem dúvida usufrui de reconhecimento consensual, é o de que o 
patrimônio escrito que a história vai acumulando seja construído no quadro de uma variante que, embora apresente uma margem de variação e inovação, tem contornos precisos, incorporados ao longo do tempo. Ora, tal variante privilegiada é a chamada variante culta ou norma culta, assim definida por ser moldada e expandida pelos segmentos socialmente mais prestigiados, ou mais escolarizados, de uma comunidade lingüística.

Vale destacar que a repressão às variantes que fogem aos padrões da norma considerada culta não é uma exclusividade do PB. Na língua espanhola falada na Argentina e em outras regiões da América do Sul, o vos, o conhecido voseo ${ }^{4}$, ou seja, o uso da forma arcaica vos do espanhol peninsular ao invés do tu para a segunda pessoa do singular, embora seja de uso corrente dos falantes da região, ainda sofre pressões do sistema escolar e de outros segmentos conservadores da sociedade. Portanto, o processo de incorporação de uma variante de menor prestígio sempre encontra sérios obstáculos por parte de grupos que se consideram guardiões da integridade da língua.

A fala passou a ser objeto de muitas investigações e tal fato pode trazer novo enfoque ao problema da variação e da mudança lingüística, sobretudo no que se refere ao ensino de língua portuguesa, que poderá adquirir uma forma mais amena de construção da norma padrão, numa perspectiva de maior aceitação da variante do aluno, sem execrar a sua forma de expressão original.

O interesse científico pela fala aumentou consideravelmente, não só em termos de Brasil, mas também em termos mundiais, o que se constata pelo grande número de pesquisas envolvendo a fala como objeto de estudo, tanto aqui, como nos Estados Unidos, França, Itália, Espanha, Portugal e vários outros países.

Esse interesse científico foi destacado por Castilho (2005), em entrevista à Revista ReVEL, quando lhe perguntaram de onde surgiu a necessidade científica de transformar a fala em um problema empírico, em uma época em que predominavam os estudos formais da linguagem e quais foram os pioneiros nesse estudo:

\footnotetext{
${ }^{4}$ Alarco Llorach explica o voseo dizendo: "como en otras lenguas, el español medieval utilizó vos en lugar de tú. Este uso ha persistido en zonas de América Central y del Río de la Plata, originando el conocido voseo.”
} 
.. pelos anos 60, a lingüística sofre modificações, entre essas a adoção do gravador portátil em substituição aos estudos de orelhada. Tal uso revelou a forma com as pessoas conversam. Nesse ínterim, a lingüística brasileira adere ao "Proyecto para el estudio de la norma linguística culta", elaborado por Juan M. Lope Blanch em 1967, adesão essa através do relatório de Nelson Rossi da UFBa [Universidade Federal da Bahia], em 1968, envolvendo equipes de Recife, Salvador, Rio de Janeiro, São Paulo e Porto Alegre.

Desta forma, foram surgindo muitas pesquisas sobre a fala e projetos para 0 seu registro, dentre os quais podemos citar o Projeto NURC (Norma Urbana Lingüística Culta do Brasil), que compreende o registro da fala de cinco capitais brasileiras (São Paulo, Rio de Janeiro, Salvador, Recife e Porto Alegre). Existem, ainda, outros projetos envolvendo a fala. Um desses projetos é o Programa da Gramática do Português Falado (PGPF), envolvendo pesquisadores de várias universidades brasileiras, que teve início em 1988, com o objetivo de produzir coletivamente uma gramática de referência com base nos dados do Projeto NURC (Castilho, 2002, p. 9).

No Brasil, há outros projetos isolados, organizados, geralmente, por professores de universidades públicas estaduais e federais, entre os quais se destacam:

Variação Lingüística no Estado da Paraíba; (VALPB) projeto iniciado em 1995, sob a coordenação do professor Dermeval Hora, contando com a colaboração de alunos Universidade Federal da Paraíba (UFPB).Tal projeto visa ao estudo sociolingüístico da comunidade de fala paraibana.

- Projeto Dialetos Sociais Cearense: a linguagem falada em Fortaleza, organizado pelas professoras Maria do Socorro Silva Aragão e Maria Elias Soares da Universidade Federal do Ceará (UFC).

- Português Oral Culto da Cidade de Fortaleza (PORCUFORT): Projeto realizado com usuários da modalidade culta de Fortaleza sob a coordenação do professor José Lemos Monteiro, um dos corpus estudado nesta pesquisa, que será detalhado e analisado no capítulo 3 . 
- Projeto VARSUL (Variação Lingüística Urbana da Região Sul); constituído oficialmente em 1990, visando à instalação de um banco de dados lingüísticos, a partir da documentação do português falado nas áreas urbanas lingüisticamente representativas dos estados do Paraná, Santa Catarina e Rio Grande do Sul. Sua realização fica a cargo de uma equipe de várias instituições, entre elas a: Pontifícia Universidade Católica do Rio Grande do Sul (PUCRS) e as universidades federais do Rio Grande do Sul, (UFRGS), de Santa Catarina (UFSC) e do Paraná (UFPR).

- Projeto Censo Lingüístico do Rio de Janeiro, atual Projeto de Estudos de Usos Lingüísticos (PEUL), iniciado em 1983, de que fazem parte, entre outros, os seguintes professores universitários: Maria Eugênia Lamoglia Duarte, Maria Cecília Mollica, Luís Fernando Roncaratti, Marta Maria Pereira Scherre, esta última da UNB.

No âmbito internacional, destacam-se os seguintes projetos envolvendo a fala:

- Panorama do Português Oral de Maputo, sob a coordenação de Christopher Stroud e Perpétua Gonçalves (1976/1977).

- "Proyecto de Estúdio de la Norma Urbana Língüística Culta" iniciado em 1967 na América Espanhola, chegando posteriormente à Espanha, cuja figura central foi Juan M. Lope Blanch do Colégio de México.

- Projeto "Conversational Analysis", iniciado em 1974, sob a coordenação de Sacks, Jefferson e Schegloff.

- "Group Aixois de Recherches en Syntaxe", projeto desenvolvido na França a partir de 1979, cuja figura central foi Claire Blanche-Benveniste, que publicou a revista Le Français Parlé.

- "Il corpus del Léssico de frequenza del Italiano parlato" (Corpus LIP), constituído na Itália entre 1990-1992, por um grupo de lingüistas liderados por Túlio de Mauro. 
O português d'além-mar também tem sido alvo de investigações sobre a fala, haja vista as iniciativas do Centro de Lingüística da Universidade de Lisboa (CLUL), que conta com dois corpora mais conhecidos pelos estudiosos brasileiros: (i) o Corpus de Referência do Português Contemporâneo (CRPC), no qual está incluso o material objeto deste estudo, cuja coordenação está a cargo de Maria Fernanda Barcelar do Nascimento, professora do CLUL; (ii) o Corpus Dialectal com Anotações Sintácticas para o Estudo da Sintaxe CORDIAL-SIN, sob a responsabilidade da professora Ana Maria Martins, também do CLUL.Portanto, há algumas décadas, a fala espontânea dos falantes da língua portuguesa passou a ser objeto de estudo, não só no Português do Brasil, neste estudo PBF (português brasileiro de Fortaleza), como do Português europeu, doravante PE. Tais estudos evidenciam diferenças significativas entre o PE e o PB, no que se refere ao sistema pronominal, à colocação dos clíticos, à concordância verbal, à não-realização dos clíticos acusativo e dativo de terceira pessoa, ao uso do ele e do the como objetos diretos, bem como às preposições que introduzem os objetos indiretos. Algumas dessas ocorrências são estudadas no presente trabalho, mediante a utilização de material dos projetos CRPC e PORCUFORT.

\subsection{Posicionamento das gramáticas normativas e prescritivas do PB em relação ao objeto indireto e aos pronomes pessoais}

As gramáticas normativas são aquelas que prescrevem as formas como se deve falar e escrever. Tais gramáticas enfatizam os conceitos de certo e errado, ou seja, o que deve ser usado, bem como o que deve ser evitado, obedecendo a determinados cânones lingüísticos. Bechara (2003), Cunha \& Cintra (2001) e Rocha Lima (1978) apresentam essas gramáticas. 


\subsubsection{Objeto indireto e os pronomes pessoais retos e oblíquos em Bechara} (2003)

Segundo Bechara (2003, p.422)

(...) os estudiosos têm encontrado dificuldades em estabelecer um rigoroso critério de identificação do complemento indireto, preferindo servir-se concomitantemente de critérios léxicos, formais e sintáticos.

Em relação à preposição que introduz o objeto indireto, Bechara (2003, p. 421) tem um posicionamento diferente, em relação a alguns gramáticos brasileiros, pois considera como objetos indiretos somente os complementos verbais introduzidos pela preposição a e, muito raramente, pela preposição para. Os complementos verbais introduzidos pelas preposições de, com e em, como nas sentenças (6a, 6b e 6c) são considerados por Bechara como complementos relativos.

(6) a) Todos nós gostamos de cinema.

b) O marido não concorda com a mulher.

c) O comerciante não confia no empregado. (Bechara, 2003, p.419)

Para Bechara (2003, p.421), um objeto indireto é um termo que apresenta as seguintes características formais e semânticas:

a) é introduzido pela preposição a (raramente para);

b) o signo léxico denota um ser animado ou concebido como tal;

c) expressa o significado gramatical de "beneficiário", "destinatário";

d) é comutável pelo pronome pessoal objetivo the ou Ihes, 
Bechara (2003, p.422) tece, ainda, as seguintes considerações sobre objeto indireto:

a) é um elemento que tem a possibilidade de ser duplicado na mesma oração, sem usar da topicalização, conforme exemplo em (7):

(7) Sempre Ihe dei ao aluno a mesma atenção.( Bechara, 2003, p.422)

b) tem uma relação mediata com o verbo, pois a relação imediata deste seria com o objeto direto,como em (8a) ou com o complemento relativo, como em (8b)

(8) a) O diretor escreveu cartas aos pais.

b) Os vizinhos se queixaram do barulho à polícia. (Bechara, 2003, p.422).

A idéia de Bechara (2003, p.419) de que os estudiosos do assunto ainda não têm uma definição precisa do que seja um objeto indireto é confirmada pelas contradições existentes entre os próprios gramáticos brasileiros a respeito de tal termo.

Ao defender a quase exclusividade da preposição a como introdutória do objeto indireto, Bechara lança mão dos exemplos (9a), (9b) e (9c), para comprovar que para a professora em (9a) não pode ser objeto indireto, uma vez que se pode compor a sentença como em (9b), em que se percebe que ao florista é realmente o objeto indireto, pois pode ser comutada com Ihe, conforme se observa em (9c).

(9) a) "Alguns alunos compraram flores para a professora" (Bechara, 2003, p. 423).

b) "Alguns alunos compraram flores ao florista para a professora."

c) "Alguns alunos compraram-Ihe flores para a professora."

A sentença compraram-Ihe ao florista seria agramatical, pois para a professora não pode comutar com lhe. 
Bechara (2006, p.41) afirma que o registro formal, especialmente o escrito, difere do registro informal em relação ao uso das formas oblíquas átonas the e Ihes. Enquanto estes preferem as formas tônicas, aqueles preferem as formas átonas, conforme se verifica em (10a) e (10b).

(10) a) Eu disse a verdade a ela ( registro informal)

b) Eu the disse a verdade (registro formal)

Em relação aos pronomes, Bechara (2003, p.164) define-os, de maneira geral, como a classe que reúne unidades em número limitado e que se refere a um significado léxico pela situação ou por outras palavras do contexto. Os pronomes pessoais, por sua vez, são definidos como designadores das duas pessoas do discurso (eu e tu) e a não pessoa, considerada terceira pessoa., pela tradição.

Embora, no que se refere aos pronomes, nossa pesquisa se restrinja ao uso dos oblíquos átonos the e Ihes com função dativa e acusativa, aos pronomes anafóricos tônicos preposicionados (a ele, a ela, a eles, a elas), e ao uso de ele com função acusativa, estamos apresentando um quadro geral dos pronomes pessoais do caso reto e do caso oblíquos, conforme se apresentam em Bechara (2003, p.164) e em outras gramáticas.

Tabela 1 - Pronomes pessoais retos e oblíquos (cf. Bechara, 2003, p.164)

\begin{tabular}{|c|c|c|c|c|}
\hline \multicolumn{5}{|c|}{ Pronomes pessoais } \\
\hline & \multirow{2}{*}{ Pessoa } & \multirow{2}{*}{ Retos } & \multicolumn{2}{|c|}{ Oblíquos } \\
\hline & & & Átonos (s/prep) & Tônicos (c/prep) \\
\hline \multirow{3}{*}{ Singular } & $1^{a}$ & $\mathrm{eu}$ & me & $\operatorname{mim}$ \\
\hline & $2^{\underline{a}}$ & tu & te & ti \\
\hline & $3^{\mathrm{a}}$ & ele, ela & Ihe,o, a, se & ele, ela, si \\
\hline \multirow{3}{*}{ Plural } & 1 & nós & nos & nós \\
\hline & $2^{\mathrm{a}}$ & vós & vos & vós \\
\hline & $3^{\mathrm{a}}$ & eles, elas & Ihes,os, as,se & eles,elas,si \\
\hline
\end{tabular}

Bechara (2003. P. 179) apresenta os pronomes ele(s) ela(s), nós como pronomes oblíquos tônicos e coloca o vós no quadro dos pronomes retos; ademais, faz referência às combinações de pronomes átonos: mo, to, Iho, no-lo, vo-lo etc. 
Sobre o uso do pronome ele como objeto direto, Bechara (2003, p. 175) afirma:

O pronome ele, no português moderno, só aparece como objeto direto quando precedido de todo ou só (adjetivo) ou se acentuado de forma enfática, em prosa e verso".

Bechara (2003, p.175) exemplifica a citação acima com as sentenças abaixo, numeradas neste trabalho como (11a) e (11b).

(11) a) "No latim eram quatro os pronomes demonstrativos. Todos eles conserva o português" [PL.1,398] (Bechara, 2003,p.175)

b) "Olha ele!" [EQ apud SS]. (Bechara, 2003, p. 175)

A respeito da colocação pronominal, (Bechara, 2003, p. 587) alude a três tipos: próclise, ênclise e mesóclise. Sobre esse assunto, o autor afirma que

\begin{abstract}
A gramática, alicerçada na tradição literária, ainda não se dispõe a fazer concessões a algumas tendências do falar de brasileiros cultos, e não leva em conta as possibilidades estilísticas que os escritores conseguem extrair da colocação de pronomes átonos.
\end{abstract}

Nas locuções verbais, Bechara (2003, p. 590) indica diferentes tipos de colocação pronominal: próclise ao auxiliar, ênclise ao auxiliar (ligado por hífen) e ênclise ao verbo principal (ligado por hífen). Ressalta, no entanto, a preferência do brasileiro pelo pronome átono proclítico ao verbo principal, fato, segundo ele, não admitido pela gramática clássica.

\title{
1.2.2 O objeto indireto e os pronomes pessoais retos e oblíquos em Cunha \&Cintra (2001)
}

Cunha \& Cintra (2001, p.137), também como Bechara (2003), afirmam não ser pacífica, ainda hoje, a conceituação de objeto indireto, definindo o mesmo como: "complemento que se liga ao verbo por meio de uma preposição" (Cunha e Cintra, 2001, p.143). Assim, os complementos dos verbos duvidar e necessitar das sentenças aqui numeradas como (12a) e (12b) são, para eles, objetos indiretos:

(12) a) Duvidava da riqueza da terra. (Cunha \& Cintra, 2001, p.143) 
b) Necessitamos de uma cabeça bem firme na terra, bem fincada na terra! (Cunha \& Cintra, 2001, p.143)

Cunha \& Cintra (2001, p.137) denominam de simultaneamente transitivos diretos e indiretos os verbos com que estamos trabalhando sob a denominação de ditransitivos. Os exemplos dos autores que ilustram a definição de tais verbos (conforme se observa em (13a) e (13b) se encaixam perfeitamente na acepção dos ditransitivos: ocorre um predicado de três lugares, com o argumento externo mais humano e dois argumentos internos, sendo o segundo, um PP semanticamente [+animado] e introduzido pela preposição $a$.

Em (13a), embora a grelha temática do verbo esteja completa, a idéia de transferência material não se evidencia, porque o verbo dar tem uma conotação semântica de verbo leve ${ }^{5}$, podendo ser substituído, juntamente com o sintagma nominal paz, pelo verbo apaziguar.

Em (13b) ocorre um verbo ditransitivo de transferência verbal, cuja grelha argumental é constituída de um argumento externo (agente), um argumento interno (tema) e um argumento interno (recipiente da ação) ou, tradicionalmente: sujeito, objeto direto e objeto indireto

a) O sucesso do seu gesto não deu paz ao Lomba. (renumerado de Cunha \& Cintra, 2001, p.13)

b) Apenas the aconselhou prudência. (renumerado de Cunha e Cintra, 2001, p.137)

Assim como Bechara (2003), Cunha \& Cintra (2003, p. 277) apresentam as formas pronominais preposicionadas ele(s), ela(s) como pronomes oblíquos tônicos e acrescentam ao quadro dos pronomes pessoais proposto por Bechara os pronomes oblíquos tônicos: comigo, contigo, conosco e convosco.

\footnotetext{
${ }^{5}$ Segundo Mateus ET al (2003, p. 312) verbos leves são aqueles que sofrem um esvaziamento lexical, que permite que o centro semântico da frase se desloque para a expressão nominal, sendo preservada, contudo, a grelha argumental, que tais verbos exibem como plenos. Neves (2000, p. 53) denomina tais verbos de verbo-suporte.
} 
Cunha \& Cintra (2001, p.277) apresentam um quadro pronominal bem próximo ao proposto por Bechara (2003), em que colocam as formas pronominais preposicionadas ele(s), ela(s) como pronomes oblíquos tônicos. Acrescentam ainda as formas pronominais: comigo, contigo, conosco e convosco, aos pronomes oblíquos tônicos.

Em relação ao uso dos pronomes do caso reto ele(s) ela(s) na função acusativa, Cunha \& Cintra (2001, p. 288) observam que:

Na fala vulgar e familiar do Brasil é muito freqüente o uso do pronome ele (s), ela(s) como objeto direto em frases do tipo: vi ele, encontrei ela. Embora esta construção tenha raízes antigas no idioma, pois se documenta em escritores portugueses dos séculos XIII e XIV, deve ser hoje evitada.

Sobre a colocação dos pronomes oblíquos átonos, Cunha \& Cintra (2001) ressaltam, como Bechara (2003), as três formas de colocação pronominais: próclise, ênclise e mesóclise. Enfatizam que a posição lógica e normal desses pronomes, quando objetos diretos ou indiretos, é a ênclise, ressaltando, no entanto, que: "Há, porém, casos em que, na língua culta, se evita ou se pode evitar essa colocação, sendo por vezes conflitante, no particular, a norma portuguesa e a brasileira". (Cunha \& Cintra, 2001, p. 309).

Em relação à próclise, consideram como uso permitido dessa colocação, entre outros, na ocorrência dos seguintes fatos:

- pronomes pessoais retos

- palavras negativas

- pronomes e advérbios interrogativos

- orações optativas

- orações subordinadas desenvolvidas

- gerúndio regido por preposição 
Cunha \& Cintra (2001, p. 316) tecem as seguintes considerações sobre a colocação dos pronomes pessoais no Brasil, explicitando-as com exemplos de autores consagrados da nossa literatura como: Érico Veríssimo, José Lins do Rego, Josué Montello e Autran Dourado, entre outros:

A colocação dos pronomes átonos no Brasil, principalmente no colóquio normal, difere da atual colocação portuguesa e encontra, em alguns casos, similar na língua medieval ou clássica.

Podem-se considerar como características do Português do Brasil e, também, do português falado nas Repúblicas africanas:

a) a possibilidade de se iniciarem frases com tais pronomes, especialmente com a forma me:

-Me desculpe se falei demais . (E. Veríssimo)

b) a preferência pela próclise nas orações absolutas, principais e coordenadas não iniciadas por palavra que exija ou aconselha tal colocação:

- Se Vossa Reverendíssima me permite, eu me sento na rede (Josué Montello)

c) a próclise ao verbo principal nas locuções verbais:

Tudo ia se escurecendo (J. Lins do Rego)

Será que o pai não ia se dar ao respeito? (Autran Dourado)

\subsubsection{O objeto indireto e os pronomes pessoais retos e oblíquos em Rocha Lima (1978)}

Rocha Lima (1978, p.219) define o objeto indireto como "o complemento que representa a pessoa ou coisa a que se destina a ação, ou em cujo proveito ou prejuízo ela se realiza". Aponta como características típicas do objeto indireto:

a) ser encabeçado pela preposição a (às vezes para); 
b) corresponder, na $3^{\underline{a}}$ pessoa, às formas pronominais átonas Ihe, Ihes;

c) não admitir - salvo raríssimas exceções - passagem para a voz passiva.

No exemplo de Rocha Lima (1978), aqui renumerado como (14), temos um verbo ditransitivo de transferência material, denominado pelo autor como bitransitivo. Ele considera a expressão aos chefes, em tal exemplo, como um caso inconteste de objeto indireto, pois é complemento de um verbo que possui um objeto direto e representa o elemento onde termina a ação. É o caso de verbos como dar, oferecer, entregar, doar, dedicar, negar, recusar, dizer, perguntar, contar, narrar, pedir, rogar, pagar, dever etc. Em suma, segundo ele, os verbos dandi ${ }^{6}$, dicendi, rogandi e seus correlatos e reversos

(14) Iracema, depois de oferecer aos chefes o licor de Tupã, saiu do bosque.( José de Alencar, citado por Rocha Lima, 1978, p.219)

Embora a edição da gramática de Rocha Lima (1978) seja bem anterior à das outras gramáticas dos autores mencionados, notam-se pontos de convergência entre a sua postura e a de Bechara (2003), em especial no que se refere à preposição que introduz o objeto indireto e na referência aos chamados complementos relativos.

No que tange aos pronomes pessoais, Rocha Lima (1978, p.283) faz algumas modificações no quadro tradicional desses pronomes pessoais, pois dá um tratamento diferenciado aos pronomes pessoais átonos e oblíquos, ao incluir entre eles, os clíticos the, Ihes, referindo-se à segunda pessoa e os pronomes de tratamento você(s), como objeto direto ou indireto. Como Bechara (2003) e Cunha \& Cintra (2001), Rocha Lima (1978) inclui as formas pronominais tônicas preposicionadas ele(s), ela(s) no quadro dos pronomes oblíquos tônicos.

\footnotetext{
${ }^{6}$ São verbos que possuem três argumentos em sua grelha argumental e semanticamente encerram a idéia de doar, dizer ou pedir algo a alguém, ou seja, são verbos de transferência material ou verbal
} 
Ao referir-se aos pronomes tônicos na função de objeto direto, Rocha Lima (1978) afirma: "Na evolução da língua foi-se abandonando o emprego das formas tônicas como objeto direto, a não ser quando regidas da preposição a

Rocha Lima (1978) exemplifica tal assertiva com a sentença de Camões, renumerada abaixo como (15):

(15) Nem ele entende a nós nem nós a ele.

Rocha Lima (1978, p. 416) destaca também a ênclise como a colocação normal dos pronomes pessoais átonos, citando os casos em que, para ele, a próclise é a colocação obrigatória e não fazendo menção à mesóclise. Esclarece, no entanto, que: nunca se pospõe pronome átono às formas do futuro do presente, nem às do futuro do pretérito.

Em relação à colocação pronominal nas locuções verbais, Rocha Lima (1978, p.421) afirma que: a interposição do pronome átono nas locuções verbais, sem se ligar ao verbo auxiliar, é sintaxe brasileira que se consagrou na língua literária a partir (ao que parece) do Romantismo.

\subsection{Posicionamento das gramáticas descritivas do PB e do PE em relação ao objeto indireto e aos pronomes pessoais}

As gramáticas descritivas oferecem um enfoque diferente das normativas, pois procuram registrar realmente as ocorrências da língua, ou seja, a forma usual de as pessoas se comunicarem, sem usar da filtragem do bom e ideal a ser praticado e do deselegante e errado a ser evitado, que permeia a gramática normativa. Portanto, a gramática descritiva não usa juízo de valor, ela simplesmente registra as ocorrências encontradas na língua.

Neves (2000, p.p. 13/14), afirma, na apresentação de sua gramática, que: 
A Gramática de usos do português constitui uma obra de referência que mostra como está sendo usada a língua portuguesa atualmente no Brasil. [...] "A Gramática de usos do português tem como objetivo promover uma descrição do uso efetivo dos itens da língua, compondo uma gramática referencial do português."

Por sua vez, Mateus et al (2003, p.17) no prefácio da Gramática da Língua Portuguesa deixam bem claro que a variedade contemplada em sua obra é a normapadrão do português europeu, esclarecendo, no entanto, que não se trata de uma gramática normativa, pois tem como objetivo a descrição e a análise de um largo conjunto de aspectos da língua portuguesa. Trata-se, portanto, de uma gramática descritiva e não, normativa ou prescritiva.

\subsubsection{O Objeto Indireto e os pronomes pessoais retos e oblíquos em Neves (2000)}

Diferentemente de Bechara (2003), Cunha \& Cintra (2001) e Rocha Lima (1978), Neves (2000) apresenta uma gramática que não tem a intenção de prescrever normas, mas de mostrar a realização da língua como de fato ocorre. Portanto, a sua Gramática de Uso baseia-se em textos escritos de vários gêneros literários, inclusive científicos, como se vê nos exemplos retirados das páginas 693 / 694 , aqui renumerado como (16 a) e (16b)

a) Ele disse isso para a senhora? (ID) ${ }^{7}$

b) A Secretaria manda regularmente materiais de construção para a Sociedade de Amigos do Bairro e Morros do Jabaquara. (CS) ${ }^{8}$

Neves (2000) tem postura semelhante à de Cunha \& Cintra (2001) acerca dos complementos objetos indiretos, no que tange à preposição que os introduz, ao considerar como objetos indiretos as palavras destacadas das sentenças extraídas da página 381, aqui renumeradas como (17a) e (17b)

\footnotetext{
${ }^{7}$ ID - abreviatura usada por Neves para indicar a obra Ídolo de Cedro

${ }^{8} \mathrm{CS}$ - abreviatura usada por Neves para indicar o jornal Cidade de Santos
} 
(17) a) Sorri e fiquei me perguntando, curiosa, se se tratava daquele mesmo reitor a que padre Luís tantas vezes se referia diante de mim.

b) Meu maior medo é perder as pessoas de que gosto.

Ao se referir aos verbos que possuem um complemento não-preposicionado (objeto direto) e um complemento preposicionado beneficiário ${ }^{9}$, Neves (2000, p.610) afirma que em tais complementos: o sujeito mais comum é um agente. $O$ objeto indireto mais ocorrente é um dativo humano representando aquele que se beneficia da transação. Nessa definição, Neves está aludindo aos verbos ditransitivos ${ }^{10}$, objeto do nosso estudo, conforme se evidencia nas sentenças extraída de Neves à página 610 e aqui renumeradas como (18a) e (18b)

(18) a) Deu ao genro um engenho com setenta escravos.

b) Punha-me a oferecer flores ao viajante.

Ao posicionar-se dessa forma sobre o complemento verbal interpretado semanticamente como beneficiário, Neves (2000) se aproxima de Bechara (2003) e Rocha Lima (1978), embora deles se distancie, como já referido, ao dar os exemplos vistos em (17a-b), em que considera os argumentos introduzidos pela preposição de como objetos indiretos. Tais exemplos seriam considerados por Bechara (2003) e Rocha Lima (1978) como complementos relativos.

Segundo Neves (2000) que há predicações com verbos de dois complementos, em que o objeto indireto tem interpretação semântica de beneficiário, que são semanticamente mais complexas, com a ocorrência de um outro predicado dentro do complemento. Exemplo encontrado em Neves 2000, p. 31) renumerado

\footnotetext{
${ }^{9}$ Atribuem-se aos complementos verbais introduzidos por preposição, tanto os objetos indiretos como os complementos relativos, determinados papéis temáticos, dependendo da idéia que encerram: fonte, locativo, benefativo, etc. Assim sendo, Neves (2000) chama de beneficiário aquele complemento cujo papel temático enfatiza a idéia de que tal complemento recebe o benefício da ação verbal.

${ }^{10}$ Neves (2000) não usa a nomenclatura ditransitivo e sim, bitransitivo.
} 
aqui como (19) em que se introduz um $\mathrm{CP}^{11}$ como o argumento interno (objeto direto) do verbo prometer e um complemento verbal com a interpretação semântica de beneficiário.

(19) O governador Ari Valadão prometeu todo apoio aos empresários (= prometeu dar todo apoio aos empresários). (p.31)

No quadro dos pronomes pessoais retos e oblíquos, Neves (2000, p.451) apresenta apenas as formas tradicionais de representação desses pronomes, sem incluir os anafóricos tônicos na categoria de oblíquos, como o fizeram Bechara (2003) fizeram Bechara e outros. A autora oferece ainda alguns exemplos do uso de pronomes, que fogem à classificação tradicional por ela apresentada no quadro pronominal e tece algumas informações sobre esses usos.

Sobre o pronome the como objeto direto, Neves (2000, p. 454) afirma: Construções com o pronome Ihe funcionando como complementos de verbos que se constroem com objeto direto não são aceitas como de norma culta. A autora (op.cit.) exemplifica essa afirmação com as sentenças aqui transcritas sob o número (20).

(20) Nunca lhe vi desse jeito. Que foi afinal?

A respeito da forma pronominal tônica ele e suas flexões, Neves (2000, p. 457) afirma:

A gramática normativa só admite que essas formas ocorram como complemento, se preposicionadas. Entretanto, especialmente na linguagem falada, mas também na escrita, ocorrem enunciados como: Benê levou ele. Levou quase à força.

Neves (2000, p. 467) fala sobre o fenômeno do redobro do clítico, fazendo as seguintes observações: [grifo da autora]

O pronome oblíquo átono pode aparecer reforçado pelo pronome oblíquo tônico da mesma pessoa (anteposto ou posposto), precedido de preposição. Esse caso vem tradicionalmente tratado como pleonasmo do objeto (direto ou indireto):

A ELE LHE repetiram aquilo de que já era sabedor.

${ }^{11}$ CP do Inglês “ Complementizer Phrase” significa um complemento que é representado por uma oração. 


\begin{abstract}
A MIM nunca ninguém ME proibiu de roubar. (CCl)
Também a ELE LHE faltava o apoio.

No caso do pronome oblíquo átono de terceira pessoa LHE, o reforço também pode ser dado por um sintagma nominal preposicionado, colocado antes ou depois do pronome pessoal:

Mas também a João LHE faltava alguma coisa para fundamentar sua proposta.

Contanto que não prejudicasse os colegas, a estes pouco se LHES dava o que Aparício fizesse.
\end{abstract}

Neves (2000), refere-se também às combinações ocorridas com os pronomes átonos: $m o$,to, Iho, esclarecendo que tais formas se restringem ao uso literário ou ao registro mais formal.

\title{
1.3.2 0 objeto indireto e os pronomes pessoais retos e oblíquos em Mateus et al.(2003)
}

Mateus et al. (2003) têm um posicionamento bem próximo ao de Bechara (2003) sobre o objeto indireto, pois consideram a relação gramatical de objeto indireto como central, sendo o seu constituinte um argumento interno de verbo de dois ou três lugares com o papel semântico de alvo ${ }^{12}$ ou fonte ${ }^{13}$, conforme se observa nos exemplos das referidas autoras à página 289 e aqui renumerados como (21a) e (21b).

a) O João ofereceu um CD [ao Pedro] .

b) O João comprou este livro raro [a um alfarrabista do Porto].

Mateus et al (2003, p.289) consideram que as propriedades típicas do objeto indireto são:

a) o constituinte com a relação gramatical de objeto indireto é, tipicamente, um argumento [+animado], mas podem ocorrer argumentos [-animado]. Nos seguintes casos: com certos predicadores de dois lugares, como os exemplos aqui

\footnotetext{
${ }^{12}$ Papel semântico de alvo - quando o argumento designa a entidade para a qual algo foi transferido.

${ }^{13}$ Papel semântico de fonte - quando o argumento está na origem de uma determinada situação, embora não tenha o seu controle.
} 
renumerados como (22a) e (22b) e com os verbos dar ou fazer, seguido de um objeto direto cujo núcleo seja um deverbal, como os exemplos de Mateus at al renumerados em (23a) e (23b).

(22) a) Obedecer ao regulamento.

b) Sobreviver ao massacre);

a) A Maria deu [uma pintura] od [às estantes] oi

b) Eles fizeram uma enorme [limpeza] od [ à casa] oi

As construções com dar e fazer admitem também a realização com oblíquo conforme os exemplos aqui renumerados como (24a) e (24b):

a) A Maria deu [uma pintura] od [nas estantes] obl.

b) Eles fizeram [uma enorme limpeza] od [na casa] obl. (Mateus et alii, 2003, p. 289).

b) Outra propriedade típica do objeto indireto, referida pelas autoras, é que esse complemento apresenta a forma dativa da flexão casual, quando representado por um pronome pessoal, conforme o exemplo de Mateus et al renumerado em (25).

(25) O miúdo deu-[lhe] o brinquedo.

c) Nas frases básicas, o constituinte com a relação gramatical de objeto indireto ocorre imediatamente à direita do objeto direto; adjacente ao verbo, se for um pronome clítico e imediatamente à direita do verbo, se o objeto direto for um SN pesado ou uma frase. As sentenças extraídas de Mateus et al e aqui renumeradas como (26a) e (26b) representam respectivamente exemplos de objetos indiretos localizados adjacentes aos verbos,uma vez que os objetos diretos são representados por um SN pesado em (26a) e uma oração em (26b). 
(26) a) Mônica deu ao namorado um lindo relógio de ouro branco.

b) A mãe pediu ao filho que não faltasse à aula

Quanto ao emprego de ele e the como objetos diretos, Mateus et al (2003, p.47) enfatizam tais usos como diferenças morfossintáticas entre o PE e o PB, conforme demonstrado nos exemplos extraídos de das autoras à página 47 e aqui renumerados como (27a) e (27b); (28a) e (28b):

(27) a) Eu vi ele na rua (PB)

b) Eu vi-o na rua (PE)

(28) a) Quero Ihe conhecer (PB)

b).Quero conhecê-lo.(PE)

O quadro dos pronomes pessoais do PE apresentado por Mateus et al (2003) traz algumas informações que os nossos gramáticos normativos do PB discutidos neste trabalho não ressaltaram: referência ao valor dêitico e o valor referencial dos pronomes retos. As autoras, como os nossos gramáticos normativos, colocam as formas pronominais preposicionadas ele(s), ela(s) na categoria dos pronomes oblíquos tônicos. 
Tabela 2 - Pronomes pessoais retos e oblíquos do PE (cf. Mateus et al., 2003, p.819)

\begin{tabular}{|c|c|c|c|}
\hline \multirow{3}{*}{$\begin{array}{l}\text { Pessoas } \\
\text { gramaticais }\end{array}$} & \multicolumn{3}{|c|}{ Casos } \\
\hline & \multicolumn{2}{|c|}{ Nominativo } & Oblíquos \\
\hline & Apenas valor dêictico ${ }^{14}$ & $\begin{array}{l}\text { Valor dêictico e } \\
\text { Valor co- } \\
\text { referencial }^{15}\end{array}$ & \\
\hline $1^{\frac{\mathrm{a}}{\mathrm{a}}}$ singular & $\mathrm{eu}$ & - & (prep.) mim, (co)migo \\
\hline \multirow{2}{*}{$2^{\underline{a}}$ singular } & tu & - & (prep) ti, (com)tigo \\
\hline & você & & (prep) si \\
\hline $3^{\mathrm{a}}$ singular & & ele, ela & (prep) ele,ela,si \\
\hline $1^{\underline{a}}$ plural & nós & & (prep) nós,con(nosco) \\
\hline \multirow[t]{2}{*}{$2^{\underline{a}}$ plural } & vós & & (prep) vós,con(vosco) \\
\hline & vocês & & \\
\hline $3^{\underline{a}}$ plural & & eles, elas & (prep) eles,elas,si \\
\hline
\end{tabular}

As autoras apresentam, ainda, quadro de pronomes pessoais clíticos do PE no qual não se observa nenhuma das inovações que ocorrem no PB.

Tabela 3 - Pronomes pessoais clíticos do PE (cf. Mateus et al, 2003, p.827)

\begin{tabular}{|c|c|c|c|}
\hline \multirow{2}{*}{ Pessoas gramaticais } & \multicolumn{3}{|c|}{ Casos } \\
\cline { 2 - 4 } & Acusativo & Dativo & Acusativo/Dativo \\
\hline $1^{\text {a }}$ singular & me & me & me \\
\hline $2^{\text {a }}$ singular & te & te & te \\
\hline $3^{\text {a }}$ singular & o/a & Ihe & se \\
\hline $1^{\text {a }}$ plural & nos & nos & vos \\
\hline $2^{\text {a }}$ plural & vos & vos & se \\
\hline $3^{\text {a }}$ plural & Os/as & lhes & \\
\hline
\end{tabular}

De acordo com Mateus et al (2003, p.849) sentenças iniciadas por pronomes clíticos são agramaticais; segundo elas, o PE moderno respeita a Lei de ToblerMoussafia $^{16}$, assim sendo:

As formas clíticas não podem ocupar a posição inicial absoluta da frase". [...]Esta generalização não é válida para as outras línguas românicas nem para o português brasileiro.

\footnotetext{
${ }^{14}$ Valor dêitico- remete para qualquer indivíduo no contexto situacional.

${ }^{15}$ Valor co-referencial é o mesmo que valor anafórico. Anáfora para a autora é o processo que consiste em utilizar uma forma lingüística ou um vazio para remeter para algo que foi dito anteriormente (o antecedente); nesta visão alargada, a anáfora distingue-se de catáfora, que consiste em remeter para algo que foi ditos no discurso posterior.

${ }^{16}$ A Lei de Tobler-Moussafia é uma lei fonética referente à colocação dos clíticos, segundo a qual um elemento sem acento próprio não deve ocupar a primeira posição absoluta da sentença.
} 
Mateus et al. (2003) apóiam pontos de vista, já defendidos por outros estudiosos, de que a ênclise ${ }^{17}$ (colocação do clítico após o verbo) é a colocação padrão básica do PE, sendo a próclise realizada somente na presença de fatores de natureza sintático-semântica ou prosódica.

Ainda segundo Mateus et al (2003.) dados de aquisição confirmam essa preferência, pois as primeiras produções de crianças portuguesas, contendo clíticos, ocorrem com o uso da ênclise. Também as gerações mais jovens tendem a realizar a ênclise, mesmo em contextos em que seria obrigatória a realização da próclise.

Os contextos de obrigatoriedade da próclise de acordo com Mateus et al. (2003, p.854) distribuem-se por diferentes classes sintático-semânticas:

- operadores de negação frásicos;

(29) João nunca me telefonou

- sintagmas nominais negativos;

(30) Nada o demoveu

- sintagmas que interrogativos, relativos e exclamativos;

(31) Quem te disse que eu ia hoje jantar contigo? (que - interrogativo)

(32) A pessoa a quem me apresentaste na conferência é interessante. (que relativo)

- complementadores simples e complexos, isto é, selecionados por uma preposição ou advérbio ou que resultam de reanálise;

(33) Perguntaram ao Zé se o Pedro Ihe entregou o livro.

- advérbios focalizadores de referência predicativa, confirmativos de atitude proposicionais aspectuais;

\footnotetext{
${ }^{17}$ As autoras esclarecem que, de acordo com o corpus estudado por Martins (1994), no século XVI e até meados do século XVII, o PE apresentava predominantemente o padrão proclítico.
} 
(34) A Maria também nos viu.

- alguns quantificadores como ambos, todos e qualquer, alguém, algo, bastantes, poucos, qualquer;

(35) Qualquer colega te empresta o livro.

- um conjunto de conjunções coordenativas (correlativas e disjuntivas);

(36) Não só a Maria o insultou como (também) o Pedro the bateu (correlativas)

(37) Ou a Maria Ihe faz todas as vontades ou o Pedro se zanga. (disjuntivas)

- construções apresentativas iniciadas por constituinte ligado discursivamente e em que o sujeito tem o estatuto de foco informacional.

(38) Aquise assinou a paz.

A colocação dos clíticos nas locuções verbais no PE apresenta o fenômeno denominado por Mateus et al. (2003), como subida do clítico, que consiste na seleção de um verbo para hospedeiro, do qual o pronome clítico não é dependente, como nos exemplos abaixo retirados de Mateus et al e aqui renumerados como (39a) e (39b),

(39) a) O convite foi-lhe finalmente enviado.

b) O João ia-se esquecendo do convite.

Sobre o redobro dos clíticos ${ }^{18}$, Mateus et al. (2003, p.883) esclarecem que, embora no PE esses clíticos exerçam funções argumentais, não ocupam a posição canônica de argumento, podendo nesse caso tal posição ser preenchida por material lexical. No PE tal preenchimento não pode ocorrer com sintagmas nominais plenos, como ocorre no espanhol, sob pena de a sentença ser considerada agramatical. $O$ clítico dativo de terceira pessoa discutido neste trabalho só pode, portanto, co-

${ }^{18}$ Voltaremos falar do redobro dos clíticos ao discutir o núcleo aplicativo. 
ocorrer com a forma pronominal forte ele/ela (s) ou com um quantificador como todos, conforme se observa no exemplo extraído de Mateus et al. e aqui renumerado como 40.

(40) Os professores ofereceram-Ihes gelado a todos eles no dia da criança.

Se a sentença em (40) fosse construída como em (41), seria considerada agramatical porque o clítico dativo estaria redobrando um sintagma nominal pleno.

(41) Os professores ofereceram-Ihe gelado ao João.

\subsection{Algumas considerações sobre os aspectos gramaticais estudados}

Considerando o exemplo de Bechara (2003) citado em (9a) à página 11 deste trabalho "Alguns alunos compraram flores para a professora", é de se questionar se não haveria aí também uma predicação mais complexa, nos termos de Neves (2000), como se verifica no exemplo (19) à página 21. Note-se que a predicação mais complexa consistiria numa construção em que seria introduzido um CP indicativo de fim,com o verbo dar como predicador. Então, para a professora seria beneficiário da ação do verbo dar e não do verbo comprar, fato contestado por Bechara (2003, p. 423) A sentença apresentaria a seguinte configuração sintática: Alguns alunos compraram flores ao florista para dar à professora.

O próprio Bechara (2003) admite o uso de para no objeto indireto (de forma esporádica), embora não seja dessa forma que se observa o uso dessa preposição na linguagem coloquial culta do brasileiro.

Mateus et al. (2003) não admitem, mesmo esporadicamente como Rocha Lima (1978) e Bechara (2003), o uso da preposição para nos contextos de complementos verbais objetos indiretos (dativos). Segundo essas autoras, o que caracteriza a realização de um objeto indireto é a presença da preposição a. Se houver a substituição da preposição a por para ou qualquer outra preposição, o complemento passa a ser oblíquo e não objeto indireto, conforme se observa nos 
exemplos retirados de Mateus et al (2003, p. 289) aqui renumerado como (42a) e (42b). Vemos que Mateus et al (2003) até admitem um objeto indireto com uma conotação [-animada], entretanto o que não admitem mesmo é a mudança da preposição $a$, até porque, pelo visto, não existe no $\mathrm{PE}$ a realização de dativo introduzido por outra preposição que não seja $a$.

(42) a) Ele deu uma pintura às estantes (objeto indireto)

b) Ele deu uma pintura nas estantes (complemento oblíquo)

O certo é que, de acordo com Mateus et al. (2003), uma relação oblíqua não se confunde com um objeto indireto, pois um objeto indireto sempre pode ser substituído pelo clítico lhe, ao passo que o complemento oblíquo (32a) não pode ser substituído por Ihe, sob pena de haver uma sentença agramatical, como em (32b). 0 complemento oblíquo pode, no entanto, ser substituído por ele(s), ela(s), antecedidos da preposição adequada, como abaixo em (43c). Os exemplos (43a),(43b) e (32c) foram retirados de Mateus et al. (2003) e aqui renumerados. As relações oblíquas podem ser estabelecidas tanto por complementos como por adjuntos, a partir da natureza do predicador verbal e expressam um leque de relações semânticas. As relações oblíquas representadas pelos adjuntos, não são complementos verbais, ou seja, não fazem parte, segundo Mateus et a., da grelha temática dos verbos.

a) Ele partilhou o almoço com o amigo.

* b) Ele partilhou-Ihe o almoço.

c) Ele partilhou o almoço com ele.

O exemplo abaixo, retirado de Mateus at al (2003, p 414), renumerado aqui como (44), representa, segundo as autoras, um adjunto oblíquo, pois por causa do calor embora participe do SV, não é irmão de V e ocupa uma posição de adjunção.

(44) A Maria saiu de casa por causa do calor. 


\subsection{A gramática sob novas perspectivas}

Ao lado dos gramáticos que apontam as normas que devem ser seguidas para a boa expressão da língua portuguesa, como Bechara (2003), Cunha \& Cintra (2001) e Rocha Lima (1978) e daqueles que descrevem a norma-padrão do português europeu, conforme informam Mateus et al. (2003), ou a norma usada em textos escritos, mais ou menos formais, conforme Neves (2000), existem aqueles lingüistas que se preocupam com as realizações da fala, ou seja, com o vernáculo. Nesse enfoque, os lingüistas tentam explicar por que determinados fatos ocorrem e que contextos os viabilizam, sem acentuar os conceitos de certo e errado da gramática normativa. É o caso, por exemplo, da proposta da Gramática do Português Falado, realizado por um grupo de professores de várias universidades brasileiras, que tem como objetivo a preparação de uma gramática referencial da variedade culta do português falado no Brasil.

Um dos enfoques que dão sustentação teórica ao presente estudo a realização do núcleo aplicativo no $P E$ e a impossibilidade de sua realização no $P B$ (pelo menos aos moldes do PE) fazem parte desse tipo de pesquisa. Torres Morais (2006) e Torres Morais \& Salles (2007), embasadas nas idéias de Pilkkänen (2002) e no modelo de Cuervo (2003), formalizado para o núcleo aplicativo no espanhol, explicam o licenciamento dos argumentos dativos nos verbos ditransitivos de transferência, através de núcleos especiais que se denominam universalmente de núcleos aplicativos.

Portanto, o estudo das realizações de fala dos falantes do português europeu e do português oral culto de Fortaleza apresenta essa idéia de conformidade entre o que se observou nessas realizações e as pesquisas com enfoque semelhante realizadas em termos de Brasil. Portanto, para estudar o complemento dativo em suas várias forma de representação, bebemos em muitas fontes, inclusive na daqueles que representam a normatização, como elemento comparativo. 


\subsubsection{As realizações de complementos com verbos ditransitivos}

O termo ditransitivo ${ }^{19}$ em relação aos verbos de três argumentos é usado por Mateus et al.(2003) e por Torres Morais e Berlinck(2004), Torres Morais(2006) Torres Morais e Salles(2007). Embora nem os autores das gramáticas normativas abordados neste estudo, como Bechara (2003), Rocha Lima(1978), Cunha \& Cintra(2001), nem Neves(2001), autora de uma Gramática de Usos do Português, tenham feito referência à denominação ditransitivos para esse tipo de verbo, todos fazem referência aos verbos cuja grelha temática é constituída por três argumentos e que se enquadram na definição de ditransitivo. Esses autores esclarecem ainda que o argumento dativo é introduzido pela preposição a e raramente, pela preposição para.

Estudos recentes, com base em dados da fala, registram que a ocorrência da preposição a nos complementos dativos, em contextos com verbos ditransitivos, vem decrescendo gradativamente ao longo dos anos, havendo, inclusive, regiões do Brasil em que tais realizações são pouco expressivas como reportam Torres Morais e Salles (2007), com base nos estudos realizados por Iseke Bispo (2004), em sua Dissertação de Mestrado (apud Torres Morais e Salles (2007)).

A perda da preposição a e a sua substituição pela proposição para nos complementos verbais dos verbos ditransitivos de transferência material e verbal sinalizam, segundo o enfoque do núcleo aplicativo proposto por Torres Morais(2007), que o PBF está perdendo a capacidade de realizar a função dativa, uma vez que a preposição para alterna em todos os contextos do PBF com a preposição a. Os complementos introduzidos pela preposição para/a são considerados como PPs e não a-DPs, como ocorre no português europeu em que a preposição a tem somente a função de marcar o caso dativo, ou seja, é uma preposição dummy ${ }^{20}$.

\footnotetext{
${ }^{19}$ Segundo Mateus et al (2003,p.296), verbos ditransitivos são verbos de três lugares [...] que selecionam um argumento externo, um argumento interno com a relação gramatical objeto directo e um argumento interno com a relação gramatical de objeto indirecto.

${ }^{20}$ É uma preposição funcional, cujo objetivo é marcar, neste estudo, Caso dativo. Não apresenta interpretação semântica.
} 
Esse fenômeno lingüístico traz conseqüências para o sistema pronominal do PB, entre elas, a perda da capacidade de realização do clítico the(s) em relação à terceira pessoa, advindo daí também a impossibilidade da realização do complemento verbal licenciado por um núcleo aplicativo, conforme ocorre no PE (Torres Morais, 2007). Essa perda dos clíticos favoreceu a que se lançasse mão de estratégias para sua substituição, incluindo-se entre essas a realização dos pronomes tônicos anafóricos preposicionados e os complementos nulos, entre outros.

A colocação dos pronomes tônicos anafóricos preposicionados ele(s),ela(s) dentro da categoria dos pronomes oblíquos é uma inovação em termos das gramáticas normativas do PB, especialmente por poderem tais formas ser introduzidas tanto pela preposição a como pela preposição para. No PE, esses anafóricos só podem ocorrer no redobro do clítico ou sem redobro, em construções de tópico ou na presença de focalizadores contrastivos como só, até, mesmo. Nesses casos, a única preposição que pode ser empregada é a preposição a, pois a presença da preposição para caracterizaria a sentença como agramatical.

\subsubsection{Inovações no sistema pronominal do PB}

O sistema pronominal brasileiro sofreu uma redução significativa, fato observado em vários estudos: Galves (1996), Freire (2005), Torres Morais \& Salles (2007), entre outros. Isto fica bastante evidenciado, quando se compara o quadro do sistema pronominal oferecido pelos gramáticos normativos brasileiros (cf. item 1.2.2, p.16 )), com o quadro do sistema pronominal desenvolvido por Torres Morais e Salles (2007), a partir das realizações de falantes do PB. Destacam-se diferenças significativas, que podem ser compreendidas levando-se em conta, de um lado, o caráter normativo e prescritivo que permeia as gramáticas tradicionais, baseadas em textos da literatura clássica, e, de outro, o registro dos fatos da língua como efetivamente ocorrem. 
Tabela 4 - Sistema pronominal: realizações de falantes do PB (cf Torres Morais (2007, p.6))

\begin{tabular}{|c|c|c|c|c|c|c|}
\hline & \multicolumn{2}{|l|}{$1^{\mathrm{a}}$ pessoa } & \multicolumn{2}{|l|}{$2^{\mathrm{a}}$ pessoa } & \multicolumn{2}{|l|}{$3^{a}$ pessoa } \\
\hline & fortes & clíticos & fortes & clíticos & fortes & clíticos \\
\hline sujeito & $\begin{array}{c}\text { eu; } \\
\text { a gente (pl) } \\
\text { nós (pl) }\end{array}$ & & $\begin{array}{c}\text { (tu) } \\
\text { você(s) }\end{array}$ & & ele (a) (s) & - \\
\hline objeto direto & $\begin{array}{l}\text { a gente (pl) } \\
\text { nós }\end{array}$ & $\begin{array}{l}\text { me; } \\
\text { nos }\end{array}$ & você (s) & $\begin{array}{l}\text { te } \\
\text { Ihe }\end{array}$ & ele (a) (s) & - \\
\hline $\begin{array}{l}\text { objeto indireto } \\
\text { complemento dativo }\end{array}$ & $\begin{array}{c}\text { para/a mim } \\
\text { a gente }(\mathrm{pl}) \\
\mathrm{ou}^{21} \\
\text { a gente } \\
\left(\mathrm{DOC}^{22}=(\mathrm{COD})\right.\end{array}$ & $\begin{array}{l}\text { me; } \\
\text { nos }\end{array}$ & $\begin{array}{c}\text { a você (s) } \\
\text { para você (s) } \\
\text { OU } \\
\text { vocês } \\
\text { (DOC) }\end{array}$ & $\begin{array}{l}\text { te } \\
\text { Ihe }\end{array}$ & $\begin{array}{c}\text { a ele(a) (s) } \\
\text { para ele(a) (s) } \\
\text { ou } \\
\text { ele (a) (s) } \\
\text { DOC }\end{array}$ & - \\
\hline
\end{tabular}

No quadro pronominal acima, percebem-se todas as inovações que permeiam as realizações dos falantes do PB no que tange às formas de expressão dos pronomes pessoais. Vale ressaltar que os falantes aqui referidos são aqueles considerados de fala culta, uma vez que as pesquisas se orientaram mais em falas do projeto NURC, que analisa as elocuções de variante culta de cinco capitais brasileiras: São Paulo, Rio de Janeiro, Porto Alegre, Salvador e Recife.

Não podemos deixar de frisar que as construções de $\mathrm{DOC}^{23}$ explícitas no quadro parecem não fazer parte das ocorrências do NURC, uma vez que Torres Morais e Salles (2007) citam estudos, em outras regiões do Brasil, como a Zona da Mata Mineira e algumas localidades de Goiás onde ocorrem essas construções.

\footnotetext{
${ }^{22}$ DOC Doble construccion object ou COD -construções de objeto duplo- construções de objetos indiretos sem auxílio de preposição, aos moldes do inglês (uso em alguns dialetos brasileiros).

${ }^{23}$ Refere-se a construções de objeto duplo, em que o argumento interno objeto indireto é introduzido sem preposição, como ocorre na língua inglesa e em alguns dialetos brasileiros.
} 
O quadro pronominal apresentado pelas gramáticas normativas do português brasileiro revela uma considerável distância entre o que tais gramáticas postulam e a realização dos falantes. Por outro lado, é perceptível que o quadro pronominal tradicional do PB coincide, em muitos pontos, com o quadro do sistema pronominal do português europeu, apresentado por Mateus et al. (2003, item 1.3.2. p. 27).

É preciso considerar, no entanto, que alguns gramáticos já apresentam esboços de uma nova postura. Bechara (2003), Cunha \& Cintra (2001) e Rocha Lima (1978) incluem os anafóricos tônicos preposicionados ele(a)(s) na categoria de clíticos oblíquos no sistema pronominal do PB. Rocha Lima (1978, p.283) considera os oblíquos Ihe(s) como pertencentes à segunda pessoa e inclui você(s) e a você(s) na categoria dos oblíquos.

A despeito de Neves (2000) ter como objetivo elaborar uma gramática referencial do português (PB), o quadro pronominal apresentado por ela não traz qualquer referência às modificações relativas aos pronomes pessoais relacionadas em Bechara (2003) e outros. É possível que tal omissão decorra do fato de Neves ter como foco as construções da língua em textos escritos de diferentes tipos, não tendo observado neles nenhuma ocorrência pronominal que merecesse destaque ou acenasse para mudanças. Vale destacar que esta

observação constitui uma suposição, pois não tivemos acesso aos textos selecionados pela autora.

\subsubsection{A colocação pronominal proclítica e enclítica no PE e no PB}

É possível que as inovações nas formas utilizadas na colocação pronominal constituam um dos aspectos em que mais se distanciam as variedades do PB e do PE.

A ênclise é a colocação ideal segundo os autores das gramáticas normativas, tanto do PE como do PE, embora ressaltem também os casos de próclise obrigatória prevista nas gramáticas dessas variedades. Embora esses autores façam referência à colocação pronominal enclítica como a mais adequada, Cunha \& Cintra (2001) 
consideram como característica do português falado no Brasil, o uso dos clíticos em início de sentença, especialmente o clítico me, como se vê no exemplo transcrito de Cunha e Cintra ( 2001, p.317) e aqui renumerado como (33).

(33) Me arrepio todo... (Luandino Vieira)

A despeito do que preconizam nossos gramáticos normativos sobre a ênclise como a colocação pronominal padrão, o que se verifica nos estudos envolvendo falantes do PB é que a próclise é a colocação preferencial. Tal fato se verifica nos Gráficos (1) e (2), em levantamento realizado por Vieira (2004), no Rio de Janeiro, com corpora ${ }^{24}$ do PB e do PE.

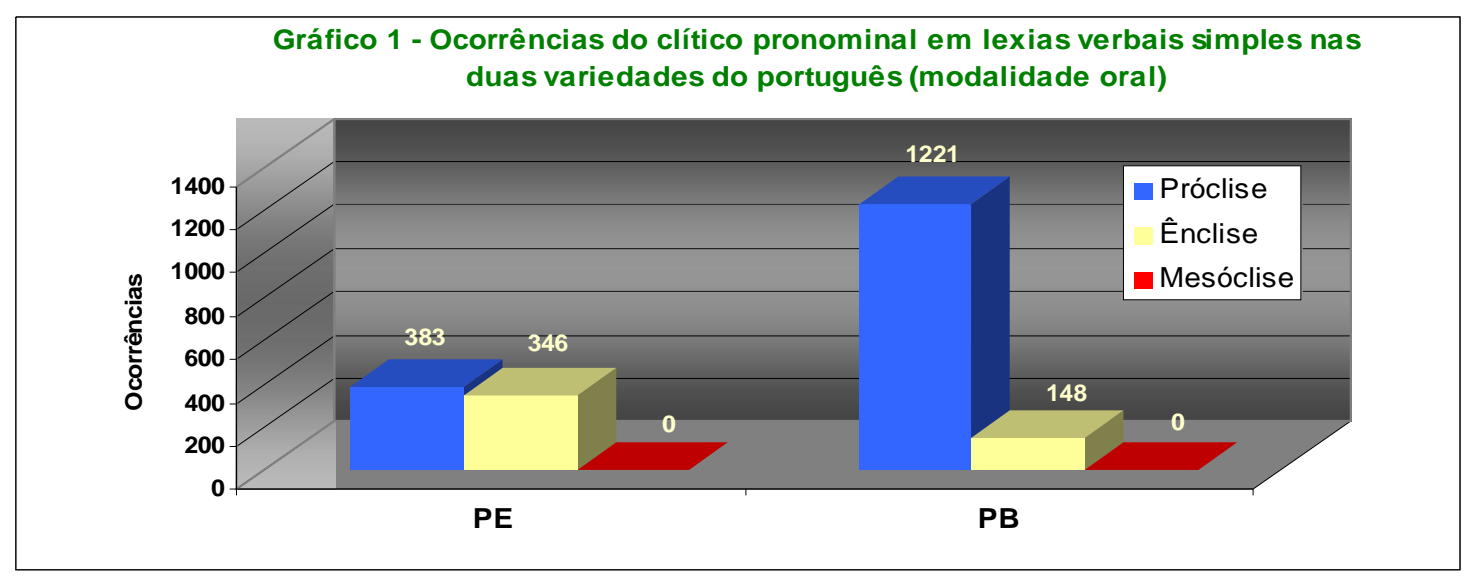

Fonte: Vieira (2004, p.189).

\footnotetext{
${ }^{24}$ A pesquisadora trabalhou com os seguintes corpora: para o PB, Norma Urbana Culta Carioca, do NURC, Programa de Estudo do Uso da Língua - PEUL e Atlas Etnolingüístico dos Pescadores do Estado do Rio de Janeiro. Para o PE utilizou o Corpus de Referência do Português Contemporâneo -(CRPC).
} 


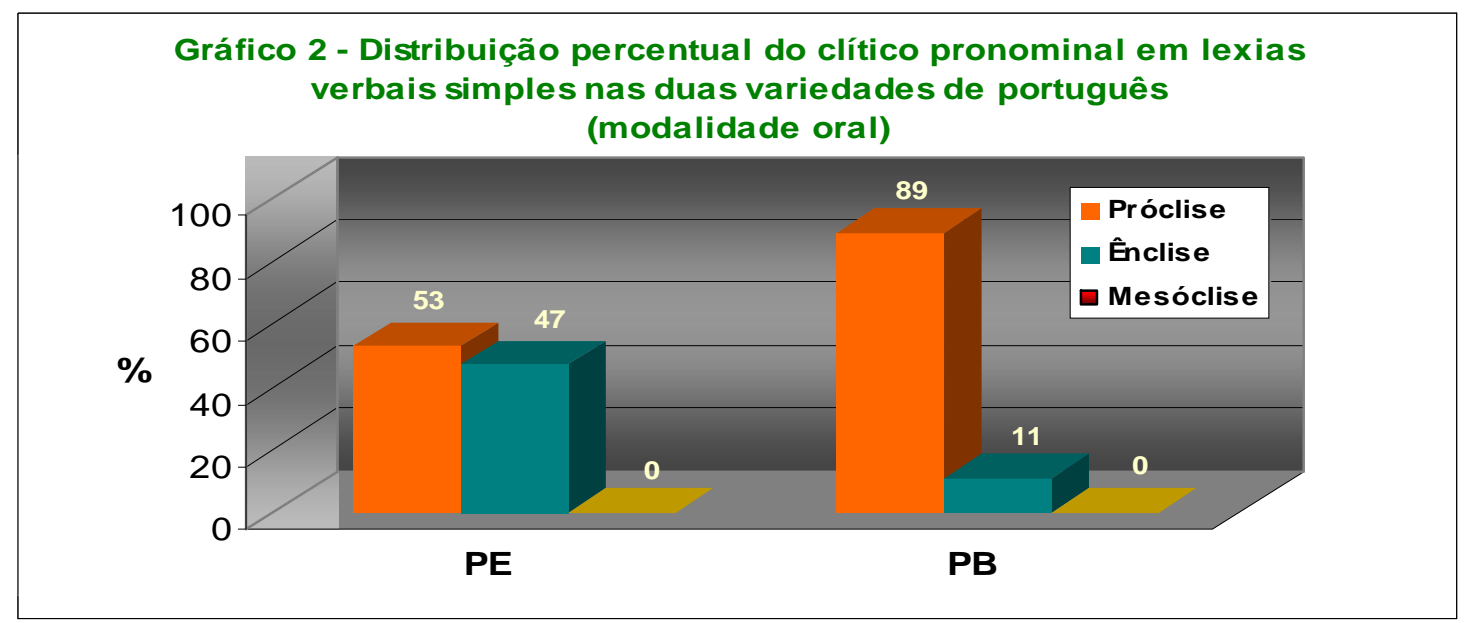

Fonte: Vieira (2004, p.189).

Observa-se nos Gráficos 1 e 2 que, no PB, houve $89 \%$ de uso da próclise (1221 ocorrências em 1369) e 11\% de ênclise (148 em 1369 ocorrências); no PE, em contrapartida, verifica-se um equilíbrio entre o uso de próclise e de ênclise. Isso indica que nossas gramáticas normativas projetam o modelo europeu para o português do Brasil.

Segundo Mateus et al. (2003), a colocação pronominal padrão básica do PE é a ênclise. Esse equilíbrio entre as realizações de próclise e de ênclise no PE, demonstrado nos Gráficos 1 e 2, sugere a presença de elementos atratores que justificam o uso da próclise, uma vez que, segundo a autora, os erros cometidos por crianças e por jovens em relação à colocação pronominal ocorrem sempre por opção da ênclise, quando deveria haver próclise (cf. item 1.3.2, p. 29).

Algo digno de nota é o fato de todos os gramáticos brasileiros referirem-se à mesóclise com uma alternativa de colocação pronominal; nos Gráficos 1 e 2, percebe-se que esta colocação não foi contemplada nem no PB nem no PE, confirmando talvez a assertiva de Mateus et al. (2003) de que essa colocação resulta da sobrevivência de uma gramática muito antiga.

Embora as formas pronominais ele(s), ela(s) sejam consideradas como objetos diretos, no quadro do sistema pronominal apresentado por Torres Morais e 
Salles (2007), as gramáticas tradicionais fazem sérias restrições a tal uso, pelo que vimos em Bechara (2003) , Cunha \& Cintra (2001),Rocha Lima (1978) inclusive em Neves (2000), que faz uma proposta diferenciada da dos gramáticos normativos.

Mais uma vez observa-se o distanciamento entre o que preconiza a gramática tradicional do PB e o que realizam os falantes dessa língua, pois sabemos que o ele acusativo é uma realização comum na linguagem falada informal do brasileiro de todos os extratos sociais. Na escrita e em contextos mais formais da oralidade, contudo, costuma-se evitar esse uso.

Desde o primeiro item desse capítulo, enfatizamos as dificuldades na aceitação oficial das mudanças, mesmo as consideradas paramétricas e que nascem por força de determinadas formas não fazerem parte do nosso vernáculo. Quando fazemos o percurso das posturas de nossos gramáticos tradicionais até chegarmos à gramática dos falantes da modalidade culta do PB, percebemos diferenças significativas entre a norma e a fala. Essas divergências dificultam a aquisição da língua considerada padrão, bem como o acesso a instâncias que exigem uma gramática em consonância com os padrões lingüísticos do português europeu, que conforme se demonstra neste trabalho estão mais e mais distantes das realizações do português brasileiro.

A respeito do PE e do PB Tarallo (1996, p.61) na conclusão de seu trabalho sobre mudanças sintáticas, afirma:

[...] a presença contínua e duradoura da tradição portuguesa no Brasil e a rigidez da língua escrita padrão têm mantido os dois dialetos muito próximos por todos esses séculos. As gramáticas faladas de cada dialeto, contudo, tomaram rumos diferentes. [...]

Vimos que a abordagem feita pelos nossos gramáticos de temas aqui enfocados como: uso da preposição introdutora do objeto indireto, uso do clítico the e a colocação pronominal está em perfeita consonância com a gramática do PE. Com certeza, tais usos não oferecem grandes dificuldades aos estudantes portugueses, uma vez que fazem parte do seu vernáculo, conforme demonstraremos no capítulo 4 ao estudarmos o corpus do CRPC. Mateus et al esclarecem que suas 
gramáticas não são normativas, mas que descrevem a língua da modalidade padrão do PE.

Com base nos estudos e comparações deste capítulo, podemos afirmar então que à proporção que os nossos gramáticos se aproximam do $\mathrm{PE}$, mais se distanciam das realizações dos falantes do PB, mesmo das realizações daqueles pertencentes a segmentos da sociedade considerados cultos.

A respeito das divergências de uso entre o PB e o PE, Bagno (2004, p.173174) relata o depoimento de um amigo português, que interessado em estudar no Brasil, matriculou-se num cursinho, ficando perplexo mediante o ensino de "português" realizado aqui:

É espantoso que todos os brasileiros falem uma língua e que, na escola, sejam obrigados a estudar outra! A gramática que a escola tenta ensinar aos brasileiros corresponde à língua que nós, portugueses, falamos em Portugal, mas não à língua do Brasil! Agora começo a entender por que os brasileiros todos dizem que português é muito difícil! Só pode ser! Afinal, eles têm de estudar uma língua que não é a deles! O português que se ensina na escola para os brasileiros é uma língua tão estrangeira quanto o espanhol ou o italiano para um português em Portugal! 


\section{CAPÍTULO 2}

\section{FUNDAMENTAÇÃO TEÓRICA E METODOLÓGICA}

$\mathrm{Na}$ introdução deste trabalho, já esclarecemos que o objetivo desta pesquisa é investigar as várias formas de realização do dativo no português oral culto de Fortaleza, contrapondo tais realizações com as realizações orais do Corpus de referência do português contemporâneo (CRPC). Portanto, neste capítulo, apresentaremos, entre outros temas, os pressupostos teóricos norteadores da pesquisa, quais sejam: a teoria gerativista e a sociolingüística variacionista.

Tais teorias, a princípio, pareciam bem antagônicas; contudo, estudos lingüísticos demonstraram que sua reunião - em alguns aspectos - viria a ser bastante produtiva.

Comentam-se também, neste capítulo, alguns trabalhos considerados relevantes para os estudos em questão e citam-se algumas pesquisas realizadas baseadas em dados provindos da Sociolingüística, com fundamentação gerativista. São referidos, entre outros, os seguintes autores: Paredes da Silva (2003), que justifica a prioridade dos aspectos sociais da sociolingüística variacionista; Miotto, Figueiredo e Lopes (2005) e Raposo (1978), que discutem a teoria dos Princípios e Parâmetros; Galves (2001), com os conceitos gerativistas de competência gramatical e competência lingüística.

A alternância dativa no PE e a perda dessa capacidade no PB ensejaram a que se trouxesse para a discussão o novo enfoque investigado por Torres Morais (2007): as realizações com núcleo aplicativo, uma escolha paramétrica, uma das propostas em que ancoramos a nossa pesquisa e que será sumarizada no item (2.3.2 p. 50). 


\subsection{O enfoque gerativista}

A Teoria dos Princípios e Parâmetros (Chomsky, 1981) tem sido a base para os estudos de variação e mudança dentro da visão gerativista de que a gramática das línguas humanas, entendida como Língua-Interna, é o sistema de conhecimentos que o falante tem representado em sua mente, o qual the permite entender e produzir um número infinito de sentenças, em sua língua materna.

A Teoria da Gramática Gerativa se ancora em dois elementos fundamentais: os princípios e os parâmetros.

Com o manifesto "Harmonia trans-sistêmica: variação inter- e intra-lingüística", Kato e Tarallo (1987) introduziram, nos estudos lingüísticos no Brasil, a conciliação entre os conceitos de encaixamento estrutural e parâmetro entendendo-se como encaixamento estrutural a idéia de que as mudanças acontecem em teia e ecoam umas nas outras

O conceito de gramática, para os gerativistas, tem a ver como conhecimento que o falante tem de sua língua materna, não havendo aí espaço para as noções de certo e errado, como vimos no capítulo anterior, ao estudarmos alguns aspectos da gramática normativa. Existe, ao contrário, a idéia de gramaticalidade ou agramaticalidade de uma sentença, que possibilita afirmar se uma dada sentença pertence ou não a uma determinada língua

Em relação aos Princípios e Parâmetros, Figueiredo Silva, Lopes e Mioto (2005, p. 24) postulam que:

A faculdade da linguagem é composta por princípios que são leis gerais válidas para todas as línguas naturais; e por parâmetros que são propriedades que uma línguas pode ou não exibir e que são responsáveis pelas diferenças entre as línguas. Uma sentença que viola um princípio não é tolerada em nenhuma língua natural provavelmente porque tem a ver com a forma como o cérebro/mente da espécie funciona, uma sentença que não atende a uma propriedade paramétrica pode ser agramatical em uma língua e gramatical em outra. 
Ainda segundo os autores (2005, p.36), no processo de aquisição da linguagem é que se efetiva a mudança lingüística, uma vez que o processo de mudança tem a ver com o acionamento paramétrico, ou seja, o valor que é atribuído ao parâmetro. Se o input (os dados lingüísticos de uma determinada língua) se torna ambíguo, a criança pode atribuir ao parâmetro um valor diferente daquele da gramática dos a

Por sua vez, Raposo (1999, p.54-55) afirma que a Gramática Universal (que reflete de maneira universal a estrutura e a organização da mente humana) regulase por dois tipos de princípios: um tipo invariável, rígido, que todas as línguas respeitam, e um outro tipo, os parâmetros, que são flexíveis, havendo possibilidade de se fixar, durante a aquisição da linguagem, uma das duas posições oferecidas, com base na informação obtida no meio lingüístico compartilhado pela criança. (Raposo, 1999, p.54-55).

Raposo oferece, como exemplo de princípio da Teoria Gerativa, o Princípio da Dependência Estrutural, que determina: as regras de movimento apenas podem mover constituintes sintáticos. Clarifica tal princípio com os seguintes exemplos (3a) e (3b) (1999, p.67), aqui renumerados como (1a) e (1b).

(1) a) O Luís comprou o carro do João.

b) O Luís comprou o carro ao João.

Embora as sentenças sejam bem parecidas, seus constituintes não são os mesmos, (pelo menos na sintaxe lusitana), pois a expressão o carro do João em (1a) forma um constituinte sintático, ao passo que na expressão o carro ao João há dois constituintes: o sintagma nominal o carro (objeto direto) e o sintagma preposicional ao João ${ }^{25}$ (objeto indireto), que apresenta a interpretação semântica de fonte/origem.

$\mathrm{Na}$ sentença (1a) no PB, haveria dois constituintes o complemento verbal objeto direto: o carro e o complemento verbal objeto indireto: do João, com

\footnotetext{
${ }^{25}$ De acordo com a proposta do núcleo aplicativo adaptado ao $\mathrm{PE}$, o constituinte ao João seria um a-DP, pois a preposição a seria apenas marcador de Caso dativo.
} 
interpretação semântica de fonte /origem. Essa diferença não inviabiliza o Princípio da Dependência Estrutural, de movimento dos constituintes, pois entende-se que o princípio não diz exatamente que expressões devem conter os constituintes. As diferenças constatadas entre o PE e o PB, em relação à preposição introdutora dos complementos verbais com interpretação semântica de origem/fonte, ocorrem por conta de opções paramétricas, pois, enquanto no PE a preposição usada nos complementos com tal interpretação é a preposição $a$, no PB usa-se, para complementos com a mesma interpretação semântica, a preposição de.

Vale ressaltar que, no Português brasileiro de Fortaleza (PBF), embora o ocorra um número considerável de uso da preposição $a$, encontramos também o uso da preposição de em complementos com interpretação semântica de fonte, conforme se observa nos exemplos do item 3.3.6 do capítulo 3 .

A teoria dos Princípios e Parâmetros é uma das vertentes que dá sustentação teórica a este trabalho, uma vez que consideramos que o clítico dativo de terceira pessoa e a preposição que introduz o objeto indireto são aquisições paramétricas. Assim é que a criança falante do PE encontra um ambiente lingüístico que oferece a possibilidade de fixação desse parâmetro afirmativo, por este constar dos dados lingüísticos primários, ou seja, estar presente naquilo que ela ouve durante a aquisição da linguagem. $O$ falante do PBF, bem ao contrário, em criança, não encontra tais realizações nos seus dados lingüísticos primários, mas, sim, outras alternativas, então, opta por elas. Duarte $(1999$, p. 19) dá suporte a esse último ponto de vista ao afirmar que:

Os clíticos dativos de terceira pessoa, bem como outras ocorrências, frutos da escolaridade, como o emprego da preposição a para introduzir objeto indireto, não fazem parte do vernáculo dos falantes do PB.

Ou seja, se o falante do PB (e, particularmente do PBF - português oral culto de Fortaleza - objeto deste trabalho) nunca escuta, em seus primeiros anos de vida (período de aquisição da linguagem), o clítico the em referência à terceira pessoa, não poderá fixar tal uso. Para confirmar o fato de que os falantes do PB de Fortaleza não têm acesso, no período de aquisição, ao uso do clítico Ihe (dativo) em referência à terceira pessoa, lançamos mão de dados de outro corpus Fortalezense de Aragão 
e Soares (1996, p. 55 /108), através dos exemplos (2a) e (2b) em que duas crianças da periferia de Fortaleza participam de uma entrevista para esse projeto:

a) Inf: não, porque quando ela tem morre' a minha mãe não tem sorte com cachorro' nem assim' com gato não, quando tem morre, o amigo de meu pai que trabalhava na SUMOV também' deu um cachorrozinho de raça a ele' sabe aí (+) os outros era' foi CINco cachorro' só cachorro, aí os outros que ele deu pros outros amigos dele tudinho' morreram, aí só quem ficou foi o nosso, aí quando o nosso tinha um ano' quando completou um ano' ele morreu, quando já tava deste tamanho aqui...(entrevista oㅡ 02, p. 55)

b) Inf: é, esse viúvo é o pai deles (+) a/perguntou à governanta' a Renata' qual era a lição que ele dava pra eles' aí ela disse (+) se eu fosse você' se Marco/ num tem aquela grande que é namorada do homem do rádio... (entrevista $n^{\circ}$ 4)

Na perspectiva do núcleo aplicativo (ver seção 2.3.2), conforme Torres Morais (2006), a não-realização do the como argumento dativo relaciona-se com o fato de no PB não existir mais a realização do a-DP, ou seja, um complemento licenciado por um núcleo aplicativo e que se realiza na presença da preposição dummy $a$. Tal perda impossibilita a realização do Ihe dativo, que em tais contextos apresenta-se também como argumento, estando em distribuição complementar com os a-DPs. Portanto, a realização dos pronomes tônicos ele(s), ela(s) apresenta-se como um alternativa de substituição desse clítico no PB, fato verificado também no PBF, conforme se observa em (2a) e (2b).

Nestes termos, o parâmetro em jogo pode ser reformulado na base de pergunta sim/não.

Há expressão morfológica de dativo de terceira pessoa?

$$
\begin{aligned}
& \text { PE - Sim } \\
& \text { PBF - Não }
\end{aligned}
$$


Os outros fatores que se seguem da resposta negativa dada ao parâmetro da variedade brasileira manifestam-se também em um conjunto de fatos "encaixados", nos termos da visão laboviana ou, em cachos, como se supõe que seja uma mudança de natureza paramétrica. Entre esses efeitos colaterais da perda do núcleo aplicativo que introduz os argumentos dativos, está o aumento do uso da preposição para e o desaparecimento da forma clítica Ihe(s) em seu uso de terceira pessoa.

Em (2a), percebemos o uso do verbo dar, de transferência material em que ocorre um argumento interno sujeito (agente) " um amigo de meu pai que trabalhava na SUMOV". O argumento interno tema - o complemento verbal objeto direto: um cachorrinho de raça e o argumento interno objeto indireto, com interpretação semântica de recipiente da ação, representado pelo anafórico tônico preposicionado a ele, substituindo meu pai. No mesmo período ocorre um objeto indireto, também com o verbo dar, mas com o argumento interno objeto indireto representado por um sintagma nominal, introduzido pela preposição para pros outros amigos. Este exemplo demonstra alguns aspectos interessantes da fala desta criança em relação ao uso do complemento verbal objeto indireto: primeiro, ela não usa o clítico lhe em referência à terceira pessoa, o que não é de se estranhar, dado que tal forma não faz parte do vernáculo dos falantes nem do PB, nem do PBF; outro fato digno de nota é que ela substitui a preposição a pela preposição para, demonstrando que conhece as duas realizações e que as considera como formas intercambiáveis de igual valor.

O exemplo em (2b) evidencia também o uso das preposições a e para na introdução do objeto indireto, mas agora o informante usa dois verbos ditransitivos de transferência com conotações semânticas diferentes: O verbo perguntar, que é semanticamente interpretado como de transferência verbal, cujo argumento interno dativo (objeto indireto) à governanta é introduzido pela preposição a e o verbo dar, com interpretação semântica de transferência material, cujo argumento interno (objeto indireto) para eles é introduzido pela preposição para. O informante do exemplo em (2b) também não realizou o clítico Ihe na terceira pessoa, como o faria 
um falante do PE, usando, ao invés do clítico, o pronome tônico anafórico ele, antecedido da preposição a.

As realizações explicitadas em (1) e (2), demonstram o intercâmbio entre as preposições a e para, numa evidência de que a preposição a perdeu a capacidade de marcar Caso dativo, tendo aí um conteúdo semântico, ou seja, é uma preposição lexical numa realização de construção ditransitiva preposicionada. No PE as construções ditransitivas representam a contraface das realizações com os a-DPs.

O uso do pronome tônico preposicionado ao invés do clítico Ihe em relação à terceira pessoa constitui uma diferença significativa entre o PE e o PB ou o PBF. Tal uso é genuíno do PB, se comparado com o PE. Nessa variedade, tal uso se restringe às sentenças com redobro do clítico ou a sentenças em contextos especiais, que apresentam elementos focalizadores como: só, também (como em "Falei só a ele sobre aquele assunto").

Retomando a questão da competência gramatical apontada por Galves (2001), podemos deduzir que o Ihe, em referência à terceira pessoa, nunca será ouvido por essas crianças de Fortaleza, conforme se observa em (2a) e (2b), logo não poderá fazer parte da competência gramatical dessas crianças; poderá, outrossim, fazer parte da sua competência lingüística, mas advindo por outras instâncias, portanto, é possível que não faça parte da sua fala espontânea, conforme mostram todos os inquéritos realizados com fortalezenses cultos, que ora analisamos. Em contrapartida, a preposição a introduzindo complementos verbais faz parte da competência gramatical dessas crianças fortalezenses, mas tal preposição perde o seu caráter de marcador de Caso dativo, conforme já referido, sendo utilizada como uma preposição lexical nas construções ditransitivas preposicionadas, fato confirmado pelo uso aleatório de a/para nos mesmos contextos.

As sentenças (3), (4), (5), (6) e (7) retiradas do CRPC (Corpus de Referência do Português Contemporâneo) demonstram um comportamento diferente do PE em 
relação ao PBF no que tange ao uso do clítico the e da preposição introdutora do complemento dativo de terceira pessoa.

(3) E eu disse-Ihes assim: «então como é? domingo é que eu vou ter folga, vós ides cozinhar... ( inq. 75 do CRPC- falante sem escolaridade).

(4) Contava-Ihes, por exemplo, os evangelhos ...(Inq. 31do CRPC -falante de baixa escolaridade)

(5) Preparam-se, vão os dois dar de comer aos bichos, vêm para baixo, vão ao futebol ver os júniores,.. (inq, 22 do CRPC - falante de baixa escolaridade)

(6) ...] «anda cá p «anda cá para dizer os pecados ao senhor abade... (inq. 31 do CRPC - falante de baixa escolaridade)

As sentenças (3) e (4), retiradas de inquéritos do CRPC, proferidas por falantes do PE sem nenhuma escolaridade e de baixa escolaridade respectivamente, apresentam o uso do clítico lhe referente à terceira pessoa, numa posição argumental, (complemento verbal: objeto indireto), já as sentença (5) e (6) realizadas também por falantes do PE sem escolaridade ou de baixa escolaridade apresentam o uso da preposição a como marcador de Caso dativo, ou seja, introduzindo um complemento verbal dativo.

A realização do clítico dativo de terceira pessoa bem como o uso da preposição funcional a como introdutora do argumento dativo por falantes do PE sem nenhuma escolaridade ou de baixa escolaridade ratifica a proposta de Galves (2001) a respeito da diferença de competência gramatical dos falantes das duas variedades. 
(7) e ao depois ele dizia sempre que eu que nunca era mulher para ganhar um tostão. e eu dizia-lhe a ele: «não tenhas medo que eu também não...( inq. 839 do CRPC falante sem escolaridade)

Outro fato a considerar é que na sentença em (7), proferida por um falante do PE sem escolaridade, ocorre o redobro do clítico. Nas realizações com redobro do clítico, o lhe não apresenta o estatuto de argumento, pois que o argumento do verbo ditransitivo de transferência verbal dizer é o pronome tônico anafórico a ele. $\mathrm{O}$ Ihe apresenta em (7), o estatuto de morfema de concordância à maneira do espanhol, ou seja, é a realização lexical do núcleo aplicativo no PE, segundo Torres Morais (2007).

As divergências lingüísticas entre 0 PE e o PBF no que tange aos complementos verbais objetos indiretos, quer seja em se tratando da preposição que os introduz, quer seja em se tratando da escolha lexical de sua realização: clítico ou anafórico preposicionado, evidenciam que a competência gramatical entre os falantes do PE e do PB é diferente. Galves (2001) distingue competência gramatical de competência lingüística; para ela, a primeira é o processo natural de aquisição da linguagem na primeira infância, que ocorre na interação lingüística (fixação dos parâmetros da gramática universal) e a segunda (a competência lingüística) é constituída por muitos outros saberes lingüísticos, adquiridos, geralmente, com a participação da escola.

Outra divergência acentuada entre PE e PB, discutida por muitos estudiosos, entre eles, Monteiro (1994) Galves (2001),Vieira (2004), Torres Morais e Ribeiro (2005) e que será abordada também neste trabalho é a colocação dos clíticos em relação ao verbo. Em PB, tal colocação segue regras próprias que estão bem distantes das que se observam em PE e das que são propostas por nossas gramáticas normativas. Observaremos essas divergências à luz da hipótese de Galves, explicitada no item 2.3.1. 
Em PE, a ênclise é a forma privilegiada de colocação, até por ser essa língua de concordância forte, ou seja, não houve a perda da distinção entre as desinências de segunda e terceira pessoas, portanto, não houve o empobrecimento do sistema pronominal, o que orienta o clítico para uma posição diferente daquela que ocupa em $\mathrm{PB}$, que privilegia a colocação do pronomes antes do verbo - próclise. A próclise, em $\mathrm{PE}$, ocorre em casos específicos, com a presença de elementos atratores dos clíticos. Em PB, a próclise é a colocação usada por excelência, pelo menos na fala, inclusive de pessoas cultas. Em uma situação de escrita mais formal, foge-se um pouco a essa regra, talvez em função das sanções das gramáticas normativas.

A Gramática Universal (UG), que constitui a previsão daquilo que é comum a todas as possíveis línguas naturais, além da variação que pode ser encontrada entre elas, inclui os princípios e os parâmetros. O fato de o espanhol optar pela próclise nas orações finitas, o português europeu privilegiar ênclise, usando próclise em contextos específicos e o português brasileiro optar pela próclise em qualquer contexto deve evidenciar uma escolha paramétrica. Assim, a sentença Me llamo Maria, se fosse realizada em espanhol, como Llamome Maria, seria algo estranho à língua, portanto agramatical. A rigor, esta forma não poderia ser produzida por um falante nativo, porque não faz parte da gramática da língua. Mas, um estudante estrangeiro poderia formulá-la, especialmente se, em sua língua-mãe, fosse proibido iniciar uma sentença com um pronome oblíquo átono.

Conforme já esclarecemos, neste trabalho, além do suporte teórico gerativista, através da Teoria dos Princípios e Parâmetros, adotamos alguns aspectos da Sociolingüística variacionista, associação já realizada em outros trabalhos acadêmicos.

Em sua tese de doutorado "Realização do acusativo e do dativo anafóricos de terceira pessoa na escrita brasileira e lusitana", Freire (2005, p.56) defende também o uso da junção da Sociolingüista com o Gerativismo, nos seguintes termos:

Em linhas gerais, serão apresentados o conceitos teóricos de dois modelos teórico-metodológicos tidos no passado como incompatíveis e 
irreconciliáveis, mas que atualmente são empregados numa colaboração amistosa na análise da variação e da mudança lingüística: a Teoria Gerativa e a Teoria da Variação. Tal incompatibilidade era sustentada pelo fato de o primeiro modelo preocupar-se com a competência do falante (a língua -l), enquanto o segundo se interessava pela língua em uso (a língua-E). No entanto, a partir da teoria de Princípios e Parâmetros de Chomsky (1981) e das decorrentes preocupações com a aquisição e a mudança lingüística, bem como do interesse pela análise diacrônica, que exige trabalho quantitativo com dados reais, percebeu-se quanto seria profícua a associação entre os modelos até então conflitantes.

Logo, o "casamento" da Sociolingüística com o Gerativismo, assumido nesta pesquisa, está avalizado por outros trabalhos da literatura acadêmica.

\subsection{O enfoque da Sociolingüística variacionista}

Como já apontado anteriormente, faz-se uso, neste trabalho, de alguns pressupostos da Sociolingüística Variacionista, especialmente de alguns aspectos metodológicos, embora não se tenha usado o VARBRUL ${ }^{26}$.

Foram usados corpora com registro de falas de informantes, dos quais foram retiradas sentenças com as várias formas de realização dos dativos no PB e no PE, as quais representariam as variáveis dependentes, que foram codificadas, tendo em vista fatores intralingüísticos, tanto morfológicos como sintáticos e semânticos. Não demos prioridade aos contextos sociais, que foram as fontes mais exploradas no início dos trabalhos com a Sociolingüística.

Os primeiros trabalhos de pesquisa dos seguidores da Sociolingüística Variacionista, centrados em diferenças fonológicas, tinham como foco prioritário os contextos sociais, considerados como o elemento principal que promove as variações. Além disso, segundo Paredes da Silva (2003, p. 67), esses trabalhos também se dedicavam a estudar a influência de fatores de natureza lingüística:

26 Segundo Scherre (1993, p. 1) os programas VARBRUL foram desenvolvidos com o objetivo de implementar modelos matemáticos que procuram dar um tratamento estatístico adequado a dados lingüísticos variáveis, analisados sob a perspectiva da teoria da variação lingüística laboviana. 
fonológica, morfofonológica, sintática, semântica etc., como elementos determinantes da variação.

Segundo Paredes da Silva (2003, p.67)

[...] a primazia dos fatores sociais tinha uma justificativa adicional: assinalava uma postura teórica oposta à idealização gerativista e mostrava o comportamento de um falante/ouvinte real, numa comunidade lingüística longe de ser homogênea. Desenvolvia-se, assim, uma sociolingüística precisa, rigorosa: em síntese, científica, apoiada nos métodos de análise quantitativa introduzidos por Labov. (1969).

De acordo com Luchesi e Araújo (2007) Um estudo sociolingüístico objetiva a descrição de um determinado fenômeno, com fundamento em dados estatísticos, a fim de analisar, captar e sistematizar variantes lingüísticas observadas em determinada comunidade de fala.

Metodologicamente, calcula-se a influência que cada fator, interno (intralingüístico) ou externo (social) ao sistema lingüístico, possui na realização de uma ou de outra variante. Com tal procedimento, a análise sociolingüística busca estabelecer a relação sincrônica e diacrônica do processo de variação que se observa na língua.

Para a Sociolingüística, que visa ao estudo dos padrões de comportamento lingüístico dentro de uma comunidade, se essa comunidade é heterogênea e plural, o seu sistema lingüístico também deve sê-lo, rompendo-se assim a identificação entre funcionalidade e homogeneidade. O outro princípio teórico da mudança lingüística tem a ver com a atualização dos processos de mudança que se realizam na variação que se dá a cada momento no comportamento lingüístico da comunidade. Deve-se levar em conta também que a mudança implica necessariamente variação, mas a variação não significa necessariamente mudança. 


\subsection{Esclarecimento sobre as hipóteses}

Considerando-se que o núcleo aplicativo, embasamento do nosso estudo, é uma proposta nova no que se refere à sua aplicação no $\mathrm{PE}$ e no $\mathrm{PB}$, tendo sido objeto de estudo nesses idiomas, em primeira mão, por Torres Morais (2006), achamos conveniente dividir esta seção em dois itens: (i) retrospectiva do estudo do núcleo aplicativo e (ii) nossas propostas com o embasamento teórico.

\subsubsection{A formulação teórica do núcleo aplicativo}

As hipóteses que permeiam o estudo sobre as várias formas de representação do dativo no PE e no PBF (realizados em contextos com verbos ditransitivos com conotação semântica de transferência material e transferência verbal) centram-se nos fundamentos teóricos do núcleo aplicativo, cuja aplicação no PE advém de estudos de Torres Morais (2006).

O núcleo aplicativo proposto por Torres Morais (2006) para o PE apresenta-se com as seguintes características: os clíticos dativos de terceira pessoa (Ihe, Ihes) comportam-se como morfemas de concordância, nos redobros obrigatórios com as formas pronominais fortes ou são argumentos DPs. Isso explica a distribuição complementar na estruturas com objeto duplo entre as formas clíticas Ihe/lhes e a forma plena a-DP do argumento dativo. Nos contextos sem o redobro, o núcleo aplicativo não se realiza lexicalmente.

(8) e ao depois ele dizia sempre que eu que nunca era mulher para ganhar um tostão. e eu dizia-Ihe a ele: «não tenhas medo que eu também não...( inq. 839 do CRPC falante sem escolaridade)

Em (8) ocorre um exemplo do clítico the como morfema de concordância, apresentando, neste contexto, a realização fonológica do núcleo aplicativo. Percebese que na sentença em (8), o clítico está redobrado com o anafórico tônico 
preposicionado a ele, que é, no caso, o argumento dativo. Vale ressaltar que único caso em que o núcleo aplicativo do PE apresenta realização fonológica é no redobro do clítico.

(9) Contava-/hes, por exemplo, os evangelhos... (Inq. 31do CRPC -falante de baixa escolaridade)

Em (9), o clítico Ihe apresenta a configuração sintática de argumento dativo, tendo sido licenciado por um núcleo aplicativo, que, como o inglês, não apresenta realização fonológica.

(10) Preparam-se, vão os dois dar de comer aos bichos, vêm para baixo, vão ao futebol ver os juniores,.. (inq, 22 do CRPC - falante de baixa escolaridade)

Em (10), ocorre um argumento dativo representado por um a-DP, ou seja, um sintagma nominal introduzido por uma preposição funcional, ou seja, uma preposição que apenas serve para marcar o Caso dativo. Esse argumento dativo é também, segundo a proposta de Torres Morais (2006), licenciado por um núcleo aplicativo sem realização fonológica.

Segundo Torres Morais (2007), a formulação teórica do núcleo aplicativo foi construída com base nas idéias de Marantz (1999) e desenvolvida no modelo de Pylkkännen (2002), que formulou a proposta do núcleo aplicativo alto e núcleo aplicativo baixo. Posteriormente, Cuervo (2003) aplicou esse modelo de Pylkkannen à língua espanhola, considerando a estrutura de objeto duplo e a estrutura preposicionada de alternância dativa, fato que comprovou a possibilidade de aplicação dessa abordagem teórica também ao PE. Apoiada nesse instrumental teórico, Torres Morais (2006) propôs aplicar a teoria do núcleo aplicativo aos fatos do PE. 
Considerando a possibilidade de que a proposta do núcleo aplicativo seja desconhecida por muitos, faremos um breve histórico, tendo como base estudos de Torres Morais (2006) sobre o assunto, para maior clareza da abordagem teórica.

A autora em seu artigo "Argumentos dativos: um cenário para o núcleo aplicativo no português europeu", faz uma retrospectiva sobre o núcleo aplicativo, enfocando-o desde a sua formulação no estudo nas línguas bantas até o estágio atual, em que aplica a teoria aos seus estudos sobre a alternância dativa no PE.

O estudo de algumas línguas bantas (chaga e chechewa) demonstrou que havia elementos (realizados foneticamente) que licenciavam o objeto indireto ou 0 oblíquo, sem os quais seria impossível considerar os objetos indiretos e os oblíquos como constituintes da estrutura argumental dos verbos. Tais licenciadores passaram a ser vistos como possível explicação para a realização de construções com objeto duplo em outras línguas,

Segundo Torres Morais (2006), Marantz(1999) reconheceu que havia identidade entre as línguas bantas e o inglês, e propôs, então, tratar as construções de objeto duplo da língua inglesa como construções aplicativas, (em que o DP-dat é interpretado semanticamente como recipiente ou beneficiário), mesmo sem a realização fonética desses núcleos como ocorria com as línguas bantas.

Representação arbórea do núcleo aplicativo no inglês, extraída de Torres Morais (2006, p. 247)

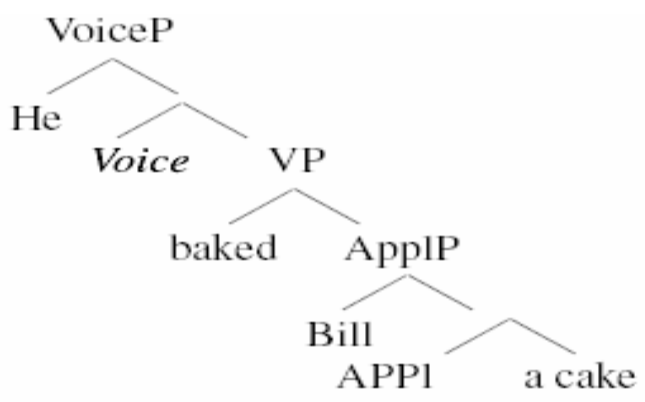

Na representação arbórea: He baked Bill a cake estamos diante de uma sentença com objeto duplo, que viabiliza a alternância dativa do inglês, cuja outra 
face, seria a ditransitiva preposicionada: He baked a cake to Bill. Na sentença da representação arbórea o DP-Dat Bill c-comanda ${ }^{27}$ assimetricamente o Dp-tema a cake. O DP-Dat foi licenciado por um núcleo aplicativo, que não apresenta realização fonológica.

Embora as descobertas de Marantz (1999) tenham sido interessantes, elas não sistematizavam a sua aplicação. Tal fato foi observado por outros estudiosos, mas é Pilkkännen (2002), segundo Torres Morais, (2006) que vai construir um modelo teórico aplicável a outras línguas. Observando as divergências entre o inglês e a língua banta Chaga, essa pesquisadora propôs a formulação de dois núcleos aplicativos: o núcleo aplicativo alto e o núcleo aplicativo baixo.

O núcleo aplicativo alto daria conta dos fatos apresentados nas línguas bantas Chaga e Chichewa, em que ocorre um relacionamento entre um evento e um indivíduo, por exemplo, em Chaga é possível a realização de uma sentença em que o argumento aplicado é interpretado como beneficiário e, em Chichewa, pode ocorrer um argumento aplicado com interpretação semântica instrumental, conforme se observa nos exemplos aqui renumerados como (11) e (12) (apud Torres Morais, 2006).

Chaga: beneficiário-Ele está comendo comida para sua esposa

(11) N -ã - i -lyì à 'm - kàk-élyà (Pylkkännen,2002)

Chichewa: instrumental - Mavuto moldou o pote de água com a faca. (Baker, 1998)

(12) Mavuto a -na -umb ir -a mpeni matsuko

O núcleo aplicativo baixo, por sua vez, em que ocorre o relacionamento entre dois indivíduos, garantiria sua aplicação ao inglês e a outras línguas. Pylkkänen

27 Sobre c-comando consultar, Mioto, Figueiredo Silva e Vasconcelos Lopes, 2003. 
(2002) observa que entre o inglês e as línguas bantas ocorrem divergências sintáticas e semânticas, embora os dois grupos apresentem construção de objeto duplo com um argumento aplicado. Uma das divergências observadas por Pylkkänen (2002), diz respeito ao fato de que apenas em chaga um participante beneficiário pode ocorrer com um verbo inergativo, como no exemplo em (11). Outra divergência entre os dois grupos é que não seria possível, no inglês, um núcleo aplicativo relacionar um argumento aplicado a um evento como nas línguas bantas chaga e chichewa, conforme se observa em (11) e (12). Em outras palavras, nas construções de objeto duplo do inglês, o núcleo aplicativo baixo denota uma relação dinâmica de transferência de posse, em que o DP mais alto se relaciona ao DPtema mais baixo.

Torres Morais (2007) informa que Cuervo, (2003) tendo por base as conclusões de Pilkkänen, (2002) formulou a hipótese da existência do núcleo aplicativo no espanhol, através das construções de redobro do clítico, em que o Ihe seria o indicador morfológico desses núcleos. Além da presença desse marcador, o núcleo aplicativo do espanhol se realiza em construções em que necessariamente ocorre um dativo com a presença da preposição a, que tem a função de marcar o Caso dativo. Se tal preposição for substituída pela preposição para, não haverá uma construção de objeto duplo, mas, sim, uma construção ditransitiva preposicionada, em que não poderá ocorrer o redobro do clítico, elemento primordial na configuração do núcleo aplicativo no espanhol. A preposição para apresenta conteúdo semântico, sendo uma preposição lexical, uma sentença como o redobro do clítico na presença de tal preposição, é considerada agramatical em espanhol. Nos exemplos (13) e (14) ocorrem estruturas de objeto duplo e da construção ditransitiva preposicionada no espanhol. 
Estrutura de objeto duplo -(Núcleo aplicativo na língua espanhola) - Exemplo extraído de Torres Morais, (2006, p.250) e aqui renumerado como (13)

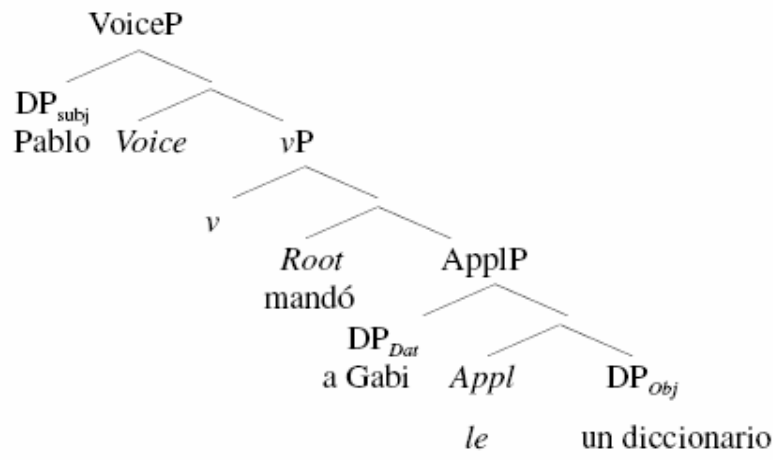

(13) Pablo Le mandó a Gabi um dicionario

Na representação em (13), o núcleo aplicativo Ihe estabelece uma relação de posse entre o Ol a Gabi e o OD Um dicionario. Note-se que o Ol realiza-se com a preposição a, marcador de Caso dativo (condição sine qua non para a ocorrência do núcleo aplicativo no espanhol.)

Estrutura ditransitiva preposicionada no espanhol (extraído de Torres Morais, 2006, p. 250, exemplo aqui renumerado como 14)

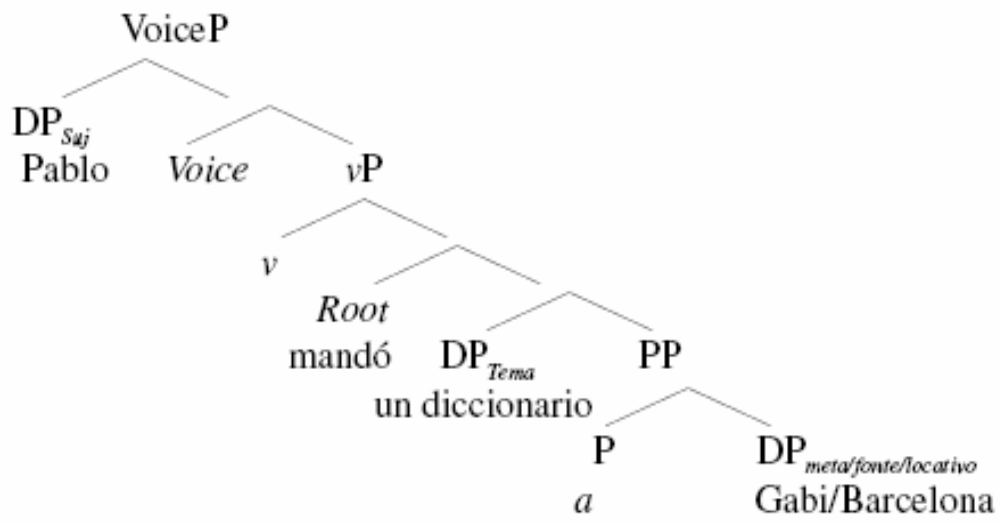

(14) Pablo mandó um diccionario para Gabi 
Na representação em (14), há um PP introduzido pela preposição lexical para. Essa preposição apresenta conteúdo semântico, portanto não pode ser usada nos argumentos aplicados, que só admitem o uso da preposição dummy

Comparando-se o núcleo aplicativo do espanhol com o do inglês, ambos com configuração de aplicativo baixo, percebem-se assimetrias entre eles: no espanhol, o núcleo aplicativo é realizado fonologicamente, através do clítico the, que apresenta nessa língua uma configuração de núcleo de concordância. No inglês, tal núcleo não apresenta realização fonológica; por outro lado, há também diferenças semânticas entre o espanhol e o inglês, tendo em vista que, no inglês, o argumento aplicado apresenta exclusivamente a interpretação semântica de recipiente ou beneficiário, enquanto no espanhol pode haver também a interpretação semântica de fonte. Além disso, o núcleo aplicativo do espanhol se configura com a presença obrigatória da preposição a no argumento aplicado, enquanto nas construções de objeto duplo do inglês isso não acontece.

Tendo por base o estudo do núcleo aplicativo nas diversas línguas, especialmente as propostas de Pilkkänen (2002) e Cuervo (2003), Torres Morais (2007) propõe a possibilidade de aplicação desse núcleo ao português europeu, tendo como inspiração as construções de objeto duplo, uma das faces da alternância dativa verificada nessa língua.

A alternância dativa do $\mathrm{PE}$, base para a hipótese da existência do núcleo aplicativo nessa língua, configura-se da seguinte forma: $\mathrm{Na}$ variante com objeto duplo, o argumento dativo se realiza como item lexical (a-DP) ou como clítico dativo de terceira pessoa (Ihe, Ihes), que estão em distribuição complementar. Na variante ditransitiva preposicionada, o Ol é um sintagma preposicionado introduzido por uma preposição lexical (a, de, para), que contribui com o sentido direcional ou locativo. Os exemplos em (8) e (9) apresentam a configuração do núcleo aplicativo e da construção ditransitiva no PE. 
Construção de núcleo aplicativo no PE (variante com objeto duplo) Exemplo extraído de Torres Morais (2006, p. 256) e aqui renumerado como (15).

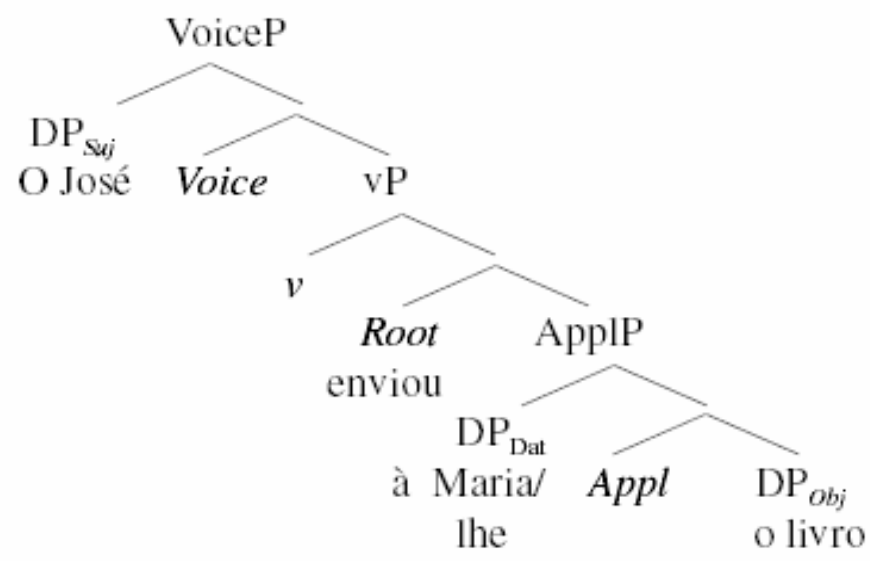

(15) José enviou a Maria o livro ou José enviou-Ihe o livro.

Em (15) o argumento dativo (à Maria ou lhe), que se acham em distribuição complementar é licenciado por um núcleo aplicativo, não realizado fonologicamente, que estabelece a relação entre o OI e o OD.

Construção ditransitiva preposicionada no PE. Extraída de Torres Morais (2006, p.257) e aqui renumerado como (16).

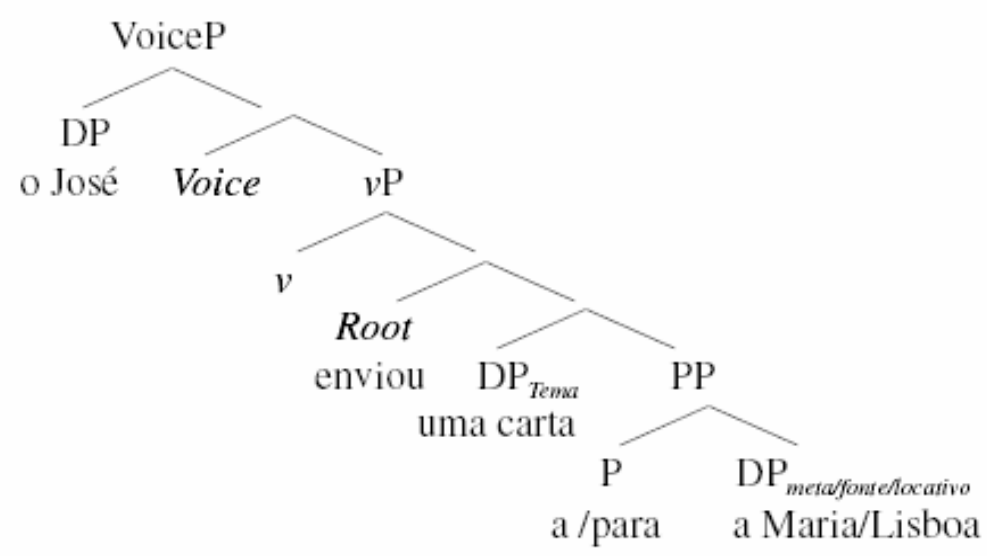

(16) O José enviou uma carta para Maria. 
$\mathrm{Na}$ estrutura ditransitiva preposicionada acima, o argumento para Maria é introduzido por uma preposição lexical, ou seja, uma preposição que apresenta conteúdo semântico, portanto tal argumento é um PP.

A alternância alternância dativa verificada em (8) e (9) é que concretiza a realização do núcleo aplicativo no PE, pois é na construção de objeto duplo que se configura a construção de aplicativo baixo, em que o argumento dativo representado por um a-DP ou pelo clítico é licenciado por um núcleo aplicativo.

O redobro do clítico em PE, obrigatório quando ocorre uma forma pronominal como ele, ela, eles, elas, como complemento de um verbo ditransitivo, confirma a idéia de que o argumento dativo é um a-DP e não um PP, pois em tais contextos a preposição a é um marcador de caso dativo, sendo impossível realizar tais redobros na presença de um PP, ou seja, com a presença da preposição para.

Existem algumas diferenças entre o núcleo aplicativo do espanhol e do PE: no espanhol, tal núcleo se realiza obrigatoriamente com uma representação fonológica, enquanto no PE tal representação pode ocorrer (nos redobros do clítico), mas não obrigatoriamente; no espanhol, o Ihe do redobro do clítico, elemento fundamental na realização do núcleo aplicativo, não tem o estatuto de argumento, é considerado morfema de concordância. No PE, o clítico tem um estatuto ambíguo: argumento nas construções em que o clítico ocorre em distribuição complementar com o a-DP, e morfema de concordância, nas construções de redobro obrigatório.

No PBF, o núcleo aplicativo não pode ser realizado, pelos menos, nos termos propostos por Torres Morais (2006) para o PE, uma vez que o PBF perdeu a capacidade de expressão do dativo, pois a realização da preposição $a$, condição sine qua non para concretização do dativo não ocorre mais, na condição de marcador de Caso dativo.

No PBF, em todos os contextos, especialmente de fala, a preposição a é substituída pela preposição para, sem que haja nenhuma modificação semântica. Em decorrência, perdeu-se também a realização do clítico dativo de terceira pessoa, tendo surgido alternativas para sua substituição. 
Portanto, a realização de núcleo aplicativo no PE, na hipótese de Torres Morais (2006), com base nos estudos acima referidos, é o terreno ideal para lançarmos as nossas bases de estudo, tanto para o PE, em que ocorre a aplicação de tal núcleo, como para o PB, cuja impossibilidade de sua realização propicia a que se verifique tal fato, no corpus que estudamos.

Como a realização do núcleo aplicativo parece ser uma opção paramétrica, estamos diante de duas variedades que, embora originariamente irmãs, comportamse diferentemente no acionamento desses parâmetros, pois permitem escolhas diferentes em suas realizações.

Vale ressaltar que no corpus analisado do PBF, encontramos aproximadamente $10 \%$ de realizações de DOC, ou seja, construções em que o objeto indireto é introduzido sem auxílio de preposição e c-comanda assimetricamente o DP-tema. Tal fato, possivelmente, oportuniza a inserção do Português Oral Culto de Fortaleza entre os dialetos brasileiros que apresentam a realização do núcleo aplicativo, como o dialeto da Zona da Mata Mineira, pesquisado por Scher (1996) e o dialeto de Goiás pesquisado por Iseke Bispo, (apud Torres Morais e Salles, 2007).

\subsubsection{Hipóteses de trabalho}

Na presente pesquisa, estamos assumindo para os clíticos dativos de terceira pessoa encontrados no CRPC a abordagem teórica do núcleo aplicativo, levantada por Torres Morais em relação ao PE de que os clíticos dativos de terceira pessoa comportam-se de duas formas: podem assumir um caráter de núcleo de concordância à semelhança do espanhol, nas construções de redobro do clítico com as formas pronominais fortes( nesse caso, como no espanhol o clítico é um núcleo aplicativo) ou são argumentos DPs, estando em distribuição complementar com a forma plena do argumento dativo. Nos contextos sem o redobro do clítico o núcleo aplicativo não se realiza lexicalmente. 
A mesma hipótese que instancia os estudos do PE serve de fundamento para os estudos do $\mathrm{PB}$, pois à proporção que se apresentam as possibilidades de realização desse núcleo no $\mathrm{PE}$, vão-se evidenciando as causas por que o $\mathrm{PB}$ não admite tal realização, pelo menos nos mesmos termos do PE.

Vale ressaltar que Torres Morais (2006) e Torres Morais e Salles (2007) fazem referência à possibilidade de ocorrer um núcleo ao núcleo aplicativo do PB, que se configuraria de forma diferente do que se observa no PE, estando mais em harmonia com o núcleo aplicativo do inglês, uma vez que se realiza nas construções de objeto duplo em que o DPdat c-comanda assimetricamente o DP tema, sem a realização lexical do núcleo aplicativo e sem a presença da preposição no argumento aplicado.

Alguns dialetos brasileiros apresentam a realização do núcleo aplicativo nos termos referidos acima, como o da Zona da Mata Mineira, pesquisado por Scher(1996). No Português Oral Culto de Fortaleza, corpus analisado do PB, encontramos aproximadamente $10 \%$ dessas realizações, o que acena para a possibilidade de inclusão do dialeto cearense entre os que apresentam a realização do núcleo aplicativo.

Outra hipótese a ser considerada neste trabalho é a de Galves,(2001) em referência à colocação dos clíticos, em que ela credita a não-realização da ênclise no PB em oposição ao PE, aos problemas de concordância, que fazem com que os clíticos do PB não alcancem COMP (sobre COMP, consultar Raposo 1998), pois detêm-se em T (tempo), não chegando sequer a AGR (concordância), o que inviabiliza a ênclise.

Neste estudo, assumindo a formulação de Torres Morais (2006) sobre núcleo aplicativo, estamos defendendo as seguintes hipóteses:

a) o PE (analisado através do CRPC) apresenta a alternância dativa que instancia a realização do núcleo aplicativo, através das construções de objeto duplo em que existe uma relação de posse entre $O \mathrm{OD}$ e o a-DP; a outra face da alternância 
dativas são as construções ditransitivas preposicionadas em que preposição apresenta carga semântica, PPs;

b) o PE (analisado através do CRPC) apresenta a realização do argumento dativo, com a realização do a-DP, ou seja, a preposição a apresenta-se como marcador de Caso dativo;

c) também no PE (analisado através do CRPC) clítico the assume um estatuto ambíguo: núcleo aplicativo nos redobros do clítico, ou seja, um núcleo de concordância e argumento a-DP licenciado por um núcleo aplicativo não realizado lexicalmente, estando em distribuição complementar com os a-DPs representado por um item lexical pleno.

Em relação ao PBF, com base em Torres Morais (2006) e Galves (2001) (essa última com o enfoque na colocação pronominal dos clíticos), assumimos que:

a) o PBF perdeu a capacidade de realizar as construções de alternância dativa, por conta da impossibilidade de realização do a-DP, ou seja, a preposição a não se apresenta mais como marcador de Caso dativo e alterna com a preposição para em todos os contextos em que se apresentam verbos ditransitivos de transferência material e verbal, sendo, portanto, uma preposição lexical;

b) a perda da realização dos a-DPs apresenta como conseqüência a incapacidade de o PB realizar o clítico dativo de terceira pessoa, que se encontra em distribuição complementar com os a-DPS ${ }^{28}$, tendo que recorrer a algumas estratégias de substituição desses clíticos, entre estas: a realização dos nulos e dos pronomes tônicos anafóricos preposicionados;

c) a concordância fraca, proposta de Galves, inviabiliza a subida do clítico no PBF, o que favorece o uso da próclise;

d) os falantes do PE (CRPC) e do PBF, assumindo também Galves, apresentam competências gramaticais distintas;

\footnotetext{
${ }^{28}$ Ocorre essa distribuição complementar no PE evidenciada pela impossibilidade de realização das duas formas simultaneamente.
} 
e) O PBF apresenta o núcleo aplicativo aos moldes do inglês com as realizações de DOC (double object construction).

\subsection{Tratamento metodológico}

O tratamento metodológico da pesquisa está sendo apresentado neste capítulo porque trabalhamos com dois corpor,a sob o mesmo enfoque teórico e metodológico. Como os corpora estão sendo descritos em capítulos diferentes (3 e 4), consideramos que seria não só repetitivo, como pouco econômico, fazer as mesmas apresentações antes de cada análise. Assim é que, antes de cada capítulo, tecemos, à guisa de orientação para o leitor, alguns comentários, que irão situá-lo quanto aos aspectos abordados no capítulo 3.

A presente pesquisa, conforme mencionado na introdução, foi integralmente pautada no Português Oral Culto de Fortaleza (PBF), em que as realizações encontradas para os diferentes usos do complemento verbais objeto indireto foram objeto de comparação com as realizações de falantes do PE, com base no corpus CRPC. Cada um desses corpora foi detalhadamente examinado, selecionando-se todas as sentenças que contêm objetos indiretos de terceira pessoa com verbos ditransitivos, representados pelas seguintes variáveis ${ }^{29}$,

-objeto indireto sintagma preposicional

- objeto indireto nulo;

- objeto indireto anafórico preposicionado;

- objeto indireto clítico.

As variáveis acima receberam uma codificação, que permitiu sua programação e o cruzamento de informações.

I = sintagma preposicionado;

\footnotetext{
${ }^{29}$ Variável lingüística é o conjunto de duas ou mais variantes, essas variantes são formas lingüísticas diferentes que veiculam um mesmo sentido.
} 


$$
\begin{aligned}
& \mathbf{a}=\text { anafórico preposicionado; } \\
& \mathbf{n}=\text { complemento nulo; } \\
& \mathbf{C}=\text { clítico. } \\
& \mathbf{t}=\text { verbo de transferência material; } \\
& \mathbf{T}=\text { verbo de transferência verbal. }
\end{aligned}
$$

Os outros fatores considerados foram:

r - o papel temático dos complementos (meta/ recipiente),

b - o papel temático dos complementos (origem/fonte);

P - uso da preposição para;

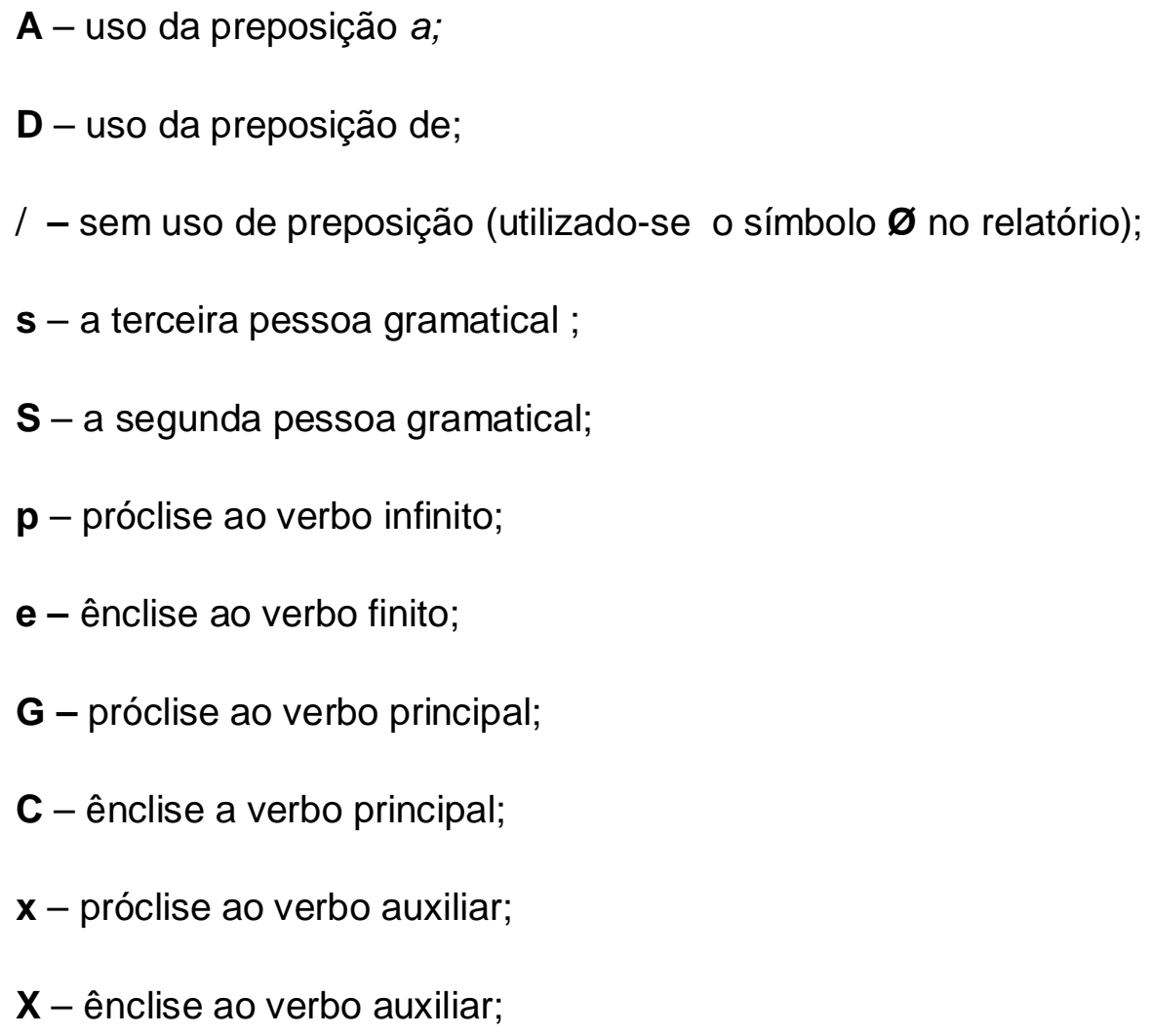


O último fator considerado na codificação foi o tipo de oração em que ocorrem os dativos ${ }^{30}$ estudados:

$\mathbf{Z}$ - sentença raiz

O - primeira coordenada

$\mathbf{N}$ - oração principal

$\mathbf{R}$ - segunda coordenada

B - oração subordinada

Como um dos suportes teóricos para o estudo do dativo de terceira pessoa em suas várias formas de realização em $\mathrm{PB}$ e PE, a sociolingüística variacionista evidencia-se no uso de corpus em $\mathrm{PB}$, com o registro da fala de fortalezenses de nível superior pertencentes a um segmento social considerado de fala culta, bem como o corpus do PE, com registro de falantes com nível de instrução diversificado.

Como variáveis, foram selecionadas somente aquelas consideradas intralingüísticas, tendo em vista que a pesquisa não estava direcionada para aspectos sociais, até porque, no PBF, todos os falantes possuem o mesmo nível de escolaridade, e pertencem à mesma comunidade regional.

Os verbos de tipologia semântica de movimento material e movimento psicológico, embora selecionados, identificados e comentados, não fizeram parte das planilhas e dos gráficos estudados, por conta de sua realização pouco significativa.

\footnotetext{
${ }^{30}$ Embora estejamos postulando neste trabalho a inexistência do dativo no PBF, continuamos com a nomenclatura, especialmente porque estamos trabalhando com dois corpora e o PE apresenta a realização de dativos.
} 
Do total de 1592 realizações selecionadas do PBF, somente foram encontradas quatro realizações com complementos introduzidos por preposições diferentes de a ou para; desta forma, desconsideraram-se estes exemplos nas planilhas e gráficos, embora tenham sido analisados e comentados à parte.

Analisamos as pessoas do discurso nos contextos em que ocorreram os complementos dativos, bem como o tipo de colocação pronominal realizada, tendo sido consideradas sentenças com próclise ou ênclise em relação ao verbo finito, ao verbo principal ou verbo auxiliar. Não consideramos realizações com mesóclise, uma vez que o estudo é sincrônico e já não ocorre tal forma, tanto no PB como no PE. Aliás, no PE ocorreu apenas uma sentença com mesóclise, para ser precisa.

Após a codificação das sentenças, procedeu-se ao cruzamento dos dados e à elaboração de planilhas que deram origem às Tabelas e aos Gráficos. O cruzamento dos dados foi realizado através de um software desenvolvido por Tiago Maia Dantas, especialmente para o conjunto.

A abordagem metodológica baseada na realização de varáveis com comparação de dados quantificados, bem como a comparação desses dados com outros resultantes algumas pesquisas sociolingüísticas evidenciam a cooperação da Sociolingüística Variacionista com a Teoria dos Princípios e Parâmetros, de orientação gerativista que, conforme já referido, está na base da interpretação das situações encontradas na pesquisa.

Com o PE (CRPC), que serviu de elemento de comparação com PBF, tivemos o mesmo procedimento, com o uso de dados coletados do CRPC (de uso oral), que incorpora as realizações de falantes com diferenças não só em relação ao grau de instrução, mas também no que diz respeito ao nível sócio-econômico. Essa heterogeneidade ocorreu também com relação ao local de origem dos falantes.

As semelhanças (em PBF) e diferenças (em PE), contudo, não foram levadas em consideração como algo capaz de trazer diferenças significativas neste estudo. Além disso, essas diferenças corroboram a hipótese de que esses fatores extralingüísticos, ou seja, sociais, não determinaram as variações nos aspectos 
estudados, o que sinaliza para uma adoção mais significativa da teoria dos princípios e parâmetros de orientação gerativista, conforme já referido, portanto, a Sociolingüística está mais relacionada com o campo metodológico da pesquisa, em que se realiza a comparação com outros trabalhos, em que se verificaram variação dos referidos aspectos no decorrer de épocas pré-determinadas, ou seja, a sincronia na diacronia.

Portanto, não se consideraram na pesquisa fatores extralingüísticos, especialmente porque no PBF, os falantes pertencem ao mesmo grupo social, detêm o mesmo nível de instrução e nasceram e moram na mesma cidade. A única diferença que, eventualmente poderia ter sido incluída, seria o fator idade; que, embora possa ser algo significativo para indicar variações, (sobretudo lexicais), não foi objeto de análise. Mesmo no corpus do PE, onde se verifica acentuada heterogeneidade entre os falantes, não se levou em conta os aspectos extralingüísticos, até por uma questão de paridade entre os dois estudos. Também vale ressaltar que, nos aspectos abordados, os falantes do PE têm o mesmo comportamento lingüístico independente do seu nível de instrução, uma vez que os clíticos dativos da terceira pessoa e a preposição que introduz o complemento dativo fazem parte, como já enfatizamos, da competência gramatical desses falantes.

Nas descrições e análise dos resultados, enfocamos todos os casos de complementos verbais realizados com verbos de transferência material e verbal, detendo-nos, no entanto, naqueles casos que representam algo mais curioso em tais realizações.

Nas descrições, utilizamos sempre a estratégia de apresentar a tabela e o gráfico e depois falar sobre o evento. Às vezes, uma mesma tabela pode dar origem a mais de um gráfico, mas como abaixo de cada gráfico consta a sua fonte, é fácil fazer a sua identificação. No decorrer das análises, trabalhamos com gráficos referentes a outros estudos, os quais foram adequadamente identificados. 
Antes de cada análise, colocamos, conforme referido algumas observações para situar o leitor, uma vez que estamos colocando a metodologia utilizada no trabalho no capítulo neste capítulo, por motivos já esclarecidos.

A descrição e a caracterização dos corpora PORCUFORT e CRPC foram colocadas nos capítulos que tratam da descrição e análise de cada corpus, ou seja, nos capítulo três e quatro respectivamente. 


\section{CAPÍTULO 3}

\section{INTERPRETAÇÃO E ANÁLISE DOS INQUÉRITOS DO PORCUFORT}

Esta parte do trabalho é dedicada à apresentação e à descrição do corpus PORCUFORT, bem como à análise dos resultados da codificação de dados desse corpus, observando os pontos em que essa pesquisa converge com alguns estudos já realizados no português do Brasil, com o mesmo enfoque. Enfatizamos os objetos indiretos nulos, não só os nulos que encontram uma co-referência no contexto, mais também aqueles que nascem por força de verbos considerados lexicalizados, que, de acordo com Dellinger et al. (2002, p. 288-289), são aqueles que poderiam admitir um complemento, mas na sentença, apresenta um caráter de intransitividade.

Apresenta-se a análise dos sintagmas nominais objetos indiretos introduzidos pelos vários tipos de preposição, inclusive aqueles que ocorrem em realizações de DOC, ou seja, sem auxílio de preposição. Todos os sintagmas nominais foram codificados, não importando se eram estratégias de substituição dos clíticos ou não. Como um dos objetivos do estudo, referidos na introdução, é observar o tipo de preposição introdutora dos argumentos internos objetos indiretos, fez-se necessário esse tipo de recorte no corpus. São analisados também os anafóricos preposicionados, uma espécie de fuga ao uso do clítico de terceira pessoa ${ }^{31}$. Analisa-se ainda o comportamento dos clíticos dativos.

Apresenta-se a análise dos sintagmas nominais objetos indiretos introduzidos pelos vários tipos de preposição, inclusive aqueles que ocorrem em realizações de DOC. Todos os sintagmas nominais foram codificados, não importando se eram estratégias de substituição dos clíticos ou não. Como um dos propósitos do estudo é observar o tipo de preposição introdutora dos argumentos internos objetos indiretos, fez-se necessário esse tipo de recorte no corpus. São analisados também os

\footnotetext{
${ }^{31}$ No corpus, os clíticos lhe (s) realizam-se quase exclusivamente em referência à segunda pessoa, mesmos assim, foram codificados, comparados e discutidos.
} 
anafóricos preposicionados, uma espécie de fuga ao uso do clítico de terceira pessoa, analisa-se também o comportamento dos clíticos dativos ${ }^{32}$.

São contempladas também neste capítulo construções do PB, como ele e the como objetos diretos, que embora rejeitadas pelas gramáticas normativas, tiveram uma realização significativa no corpus.

Os resultados são analisados sob a perspectiva da tipologia semântica dos verbos: transferência material e transferência verbal, levando-se em consideração o tipo de oração em que tais fatos lingüísticos ocorrem, bem como a preposição que introduz os sintagmas nominais e os anafóricos tônicos preposicionados.

\subsection{Apresentação e caracterização do corpus Português Oral Culto de Fortaleza (PORCUFORT)}

O corpus identificado como PORCUFORT (Português Oral Culto de Fortaleza) resulta de uma pesquisa realizada na Universidade Estadual do Ceará, sob a orientação do professor José Lemos Monteiro, com o auxílio das bolsistas do CNPq Aluísa Alves de Araújo e Kátia Oliveira.

O coordenador do projeto segue a metodologia do NURC, objetivando o registro da linguagem oral culta do fortalezense, tendo por base a realização de inquéritos orais de que participam pessoas naturais de Fortaleza de ambos os sexos, com formação superior, cujos pais são cearenses e, em sua maioria, fortalezenses. Os participantes são distribuídos em três grupos, de acordo com a faixa etária:

- primeira faixa: de 25 a 39 anos;

- segunda faixa: de 40 a 50 anos;

- terceira faixa: de 50 a 70 anos ou mais.

\footnotetext{
${ }^{32}$ No corpus, os clíticos lhe $(s)$ realizam-se quase exclusivamente em referência à segunda pessoa, mas foram codificados, comparados e discutidos.
} 
Os inquéritos foram realizados de forma a contemplar uma linguagem mais coloquial, através de gravações com dois informantes que falam sobre assuntos do dia-a-dia (D2), uma linguagem menos informal (DID), de que participam dois documentadores e um informante; nesses inquéritos, discutem-se determinados temas, como por exemplo, "As doenças e a profissão de médico", "A família", "A alimentação", com a interferência dos documentadores.

Há também inquéritos que contemplam uma linguagem mais elaborada - as denominadas elocuções formais (EF) - de que fazem parte aulas, conferências, palestras.

O corpus é constituído por 62 inquéritos, sendo 13 diálogos informais (D2), 30 inquéritos com explanação de temas mais formais (DID), com a participação de dois documentadores, e 19 inquéritos com elocuções formais (EF)

Tais inquéritos se realizaram entre 1993 e 1994.

Em cada inquérito, consta uma série de dados relevantes para a pesquisa. Primeiro, são apresentadas informações sobre o inquérito: data, local, tipo de inquérito, tema, documentador; em seguida, apresentam-se informações sobre o locutor: nome, sexo, idade, naturalidade, domicílio, zona de residência (bairro), viagens (para onde e por quanto tempo), formação universitária (graduação e outros cursos); conhecimento de línguas estrangeiras; profissão e outras atividades. Por último registram-se informações como: estado civil; naturalidade do pai, da mãe e do cônjuge; ocupação do pai, da mãe e do cônjuge.

Selecionamos 39 inquéritos do Porcufort, dentre os quais, 13 fazem parte dos diálogos entre dois informantes (D2), 13 pertencem a diálogos menos informais (DID) e 13 fazem parte das elocuções formais, havendo nos inquéritos estudados um total de 348.049 palavras. 


\subsection{Exemplos de complementos dativos realizados por falantes do PBF}

Relacionamos abaixo alguns exemplos de falantes do PB, envolvendo verbos ditransitivos, que, segundo Mateus et al (2003, pág.296), são verbos de três lugares, que selecionam um argumento externo com a relação gramatical de sujeito, um argumento interno com a relação gramatical de objeto direto e um argumento interno preposicionado com a relação gramatical de objeto indireto.

Outro fato a ser destacado é que todas as sentenças se realizam com verbos com interpretação semântica de transferência material ou verbal e movimento material ou psicológico e com um argumento externo semanticamente interpretado como agente, um argumento interno interpretado como tema e um argumento interno preposicionado com interpretação semântica de recipiente, /meta, destinatário, fonte. (Berlinck 1996),

As sentenças selecionadas do PB (PORCUFORT) abrangem todas as formas de realização do dativo, conforme se observa nos exemplos abaixo: dativos nulos, dativos realizados com os clíticos Ihe(s), dativos realizados com sintagmas nominais e com anafóricos preposicionados introduzidos pelas preposições a e para e por sintagmas nominais introduzidos sem auxílio de preposição

\section{Dativos nulos}

a) Inf. 1 - aí bem aí ele pegou e falou com o Paulo né?... disse [] que queria ir emBOra (inq 02) (a Paulo, nulo recuperado no contexto da sentença)

b) Inf. 1 ... mas a condição de ficar era só se:: ele passasse e ninguém pode ficar nessa... ne? nesse PROpósito né?... de deixar matricular:: e dar uma:.... promoção [ ] quando a criança (Inq.07) (nulo recuperado no texto $=$ a criança) 


\section{Dativos realizados com o clítico Ihe (Segunda pessoa)}

a) Inf. 1 exatamente... agora eu não sei você já deve ter visto... um trabalho MEU... aliás até um projeto de monografia sobre Renovação Carismática Católica... num sei se eu... Ihe Ihe emprestei (Inq 33)

b) Inf. 2 - então mas eu aí aí é onde eu lhe pergunto a Justiça ... a ustiça não a LEi ... é para ...o pobre ou para o rico? ... a lei (Inq11).I

\section{Dativos realizados com sintagmas nominais introduzidos pelas preposições} a/para

a) Inf. 2- porém um grande mestre nunca ensina aos seus alunos todos os truques. Inq 45

(b)Inf. 2- é como eu dizia eu estava dizendo pra minha cunhada que é professora de Letras... que no tempo que estudei no Hilza Diogo (Inq.48)

Dativos realizados com sintagmas nominais com construções de objeto duplo (DOC)

a) Inf. ela ... eu tinha pedido [ ] o rapaz ... nove mil mas deixa e cheque pra segunda-feira ... NÃO o Moacir ... 1 cabe-ça" (inq 11)

b) Inf. 2 - ah agora eu vou te perguntar tu que é... que ensina literatura... que literatura vai dar [ ] esses aluno da quinta série? que tipo de literatura? (Inq.116)

\section{Dativos representados por pronomes tônicos preposicionados}

DÊ terra pro nordestino... dê... dê condição pra ele... tire os juros bancários... ajude a econo-mia nordestina a crescer (Inq. 17) 


\subsection{Descrição e análise das ocorrências do PBF referentes aos complementos dativos em suas várias formas de representação.}

A descrição e análise das tabelas e dos gráficos a seguir visam a uma maior clareza dos fenômenos lingüísticos observados nesta pesquisa. Portanto, alguns foram analisados sob diferentes perspectivas, por exemplo: tipo de verbo quanto à tipologia semântica, tipo de oração em que se deu o evento, tipo de preposição que introduziu o complemento, gerando assim mais de uma forma de representação. A respeito de cada caso foi elaborado um gráfico e uma tabela, às vezes, dois gráficos um com a quantificação dos dados e outro com a sua distribuição percentual. Uma mesma tabela dá, às vezes, origem a mais de um gráfico, mas isso é facilmente perceptível por conta de que sob cada gráfico consta a fonte que lhe deu origem.

Vimos a necessidade de dar esses esclarecimentos porque a metodologia da pesquisa foi apresentada no capítulo 2. O fato de estarmos trabalhando com dois corpora, dificultou a sua colocação antes de cada capítulo da análise, pois tal procedimento seria, não só, repetitivo, como pouco econômico.

\subsubsection{Ocorrências das várias formas de representação do dativo com verbos de transferência material e de transferência verbal no PBF}

A codificação dos dados nesta parte da pesquisa levou em conta os verbos da seguinte tipologia: transferência material e transferência verbal (Berlinck, 1996, p.128-133). 
Tabela 5 - Ocorrências de dativos com verbos de transferência material e verbal, por tipo de dativo

\begin{tabular}{|c|c|c|c|c|c|c|}
\hline \multirow[t]{2}{*}{ Tipo de dativo } & \multicolumn{2}{|c|}{$\begin{array}{c}\text { Verbos de } \\
\text { transferência material }\end{array}$} & \multicolumn{2}{|c|}{$\begin{array}{c}\text { Verbos de } \\
\text { transferência verbal }\end{array}$} & \multicolumn{2}{|l|}{ Total } \\
\hline & $\begin{array}{c}\mathbf{N}^{\circ} \text {. de } \\
\text { ocorrências }\end{array}$ & $\%$ & $\begin{array}{c}\mathbf{N}^{\circ} \text {. de } \\
\text { ocorrências }\end{array}$ & $\%$ & \begin{tabular}{c|}
$\mathbf{N}^{\circ}$. de \\
ocorrências
\end{tabular} & $\%$ \\
\hline Nulo & 611 & 38,37 & 593 & 37,24 & 1204 & 75,62 \\
\hline Sintagma nominal & 167 & 10,48 & 60 & 3,68 & 227 & 14,13 \\
\hline Anafórico preposicionado & 63 & 3,95 & 55 & 3,45 & 118 & 7,75 \\
\hline Clítico & 15 & 0,94 & 28 & 1,75 & 43 & 2,69 \\
\hline Total & 856 & 53,84 & 736 & 46,16 & 1592 & 100,16 \\
\hline
\end{tabular}

Fonte: Inquéritos do Porcufort, 1993-1994.

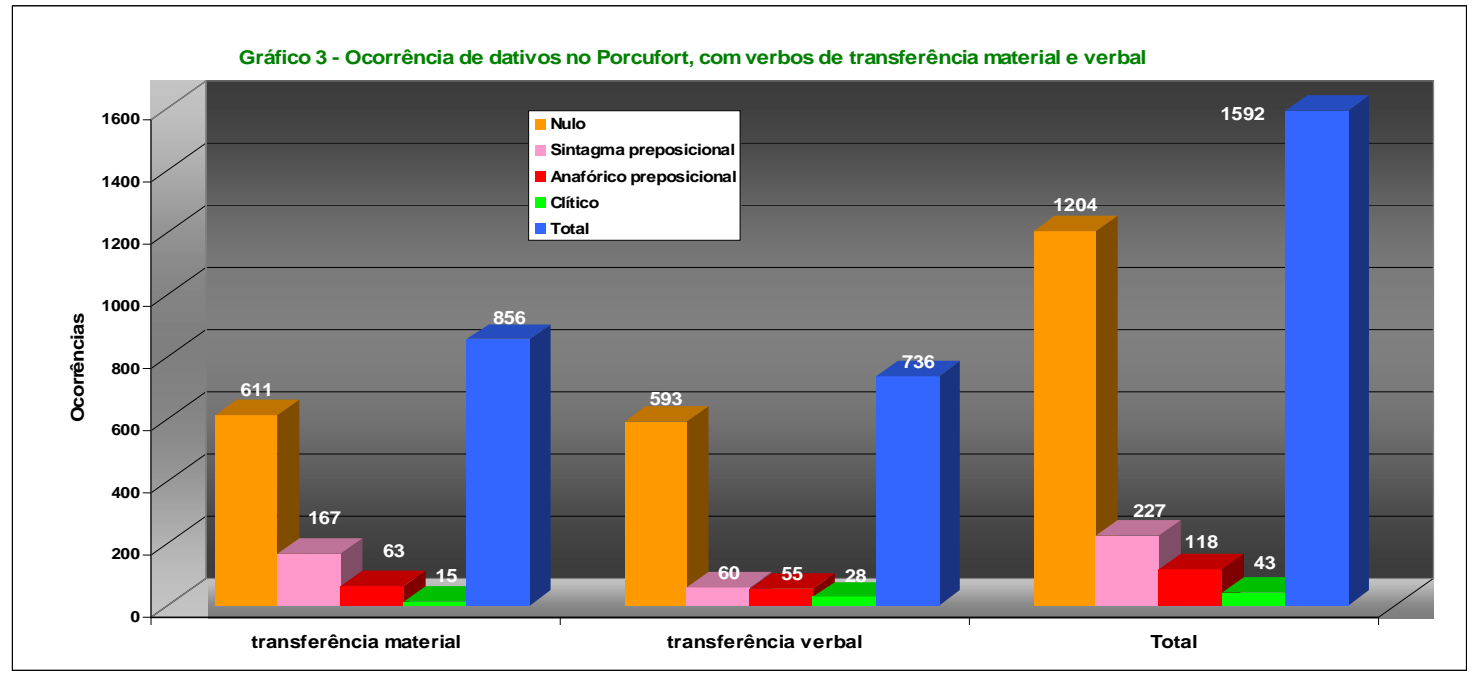

Fonte: Tabela 5

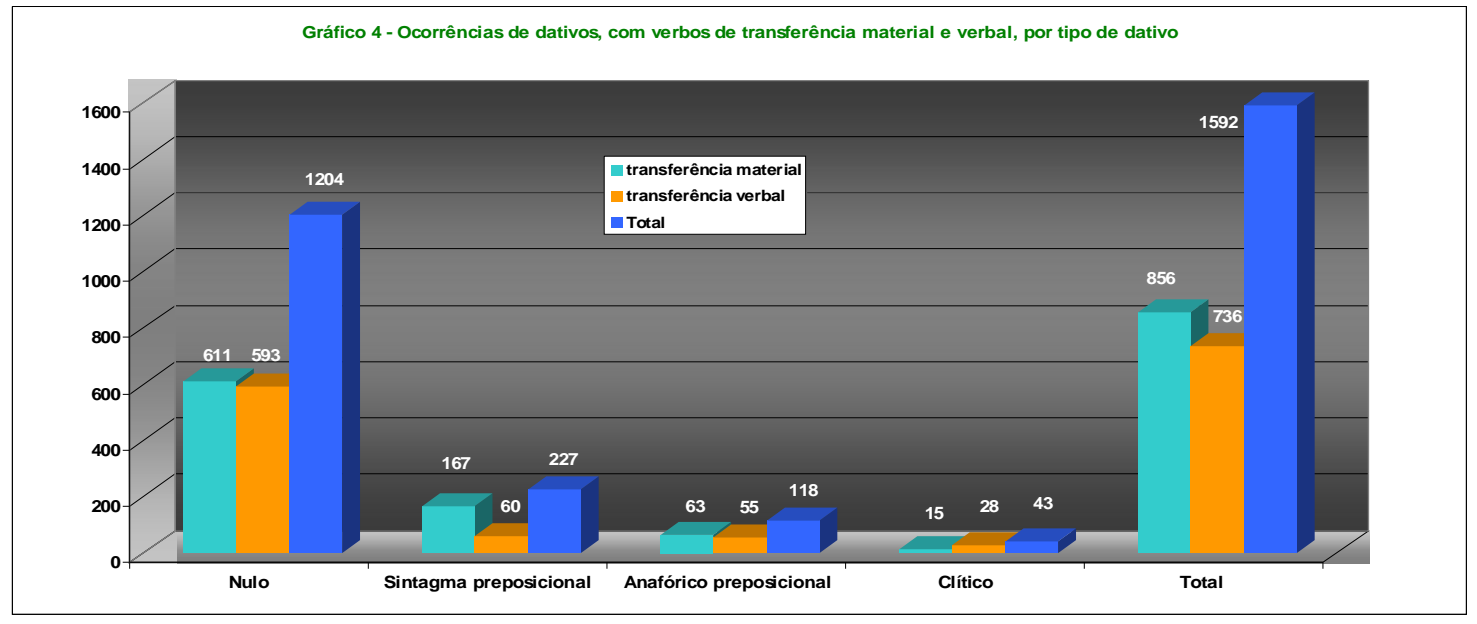

Fonte: Tabela 5 


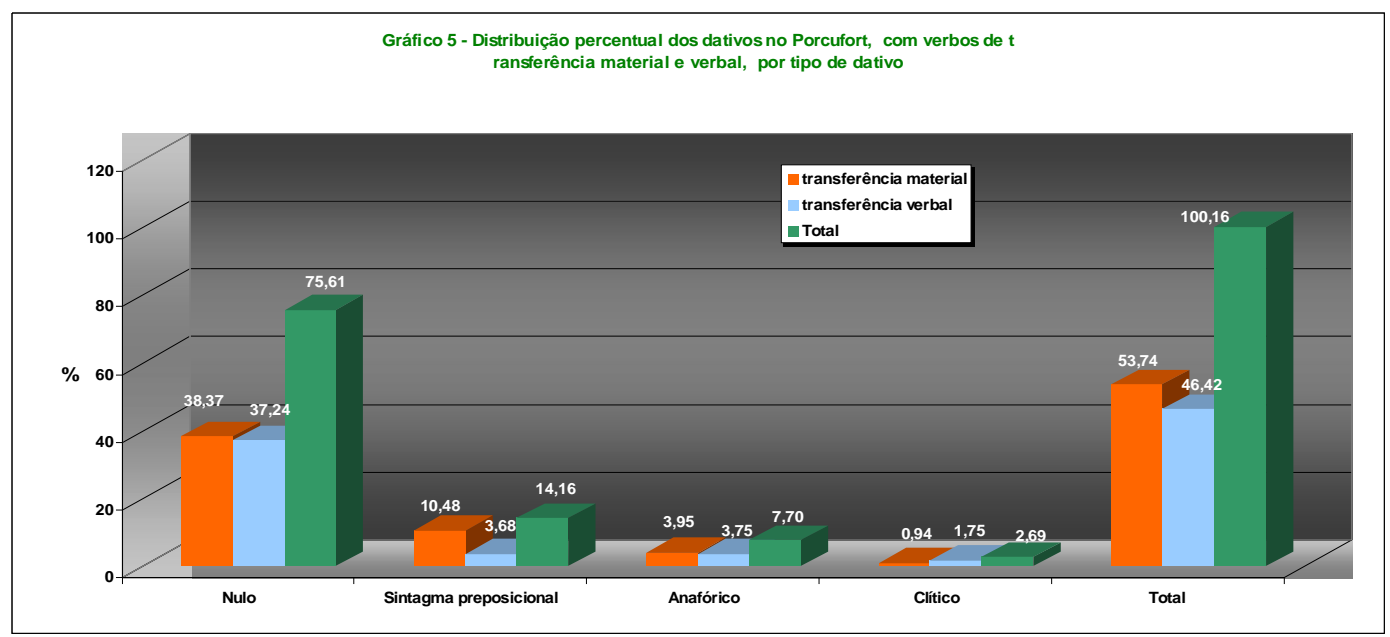

Fonte: Tabela 5

Como podemos observar na Tabela 5 e nos Gráficos 3 e 4, foram quantificadas as várias realizações do dativo com verbos de transferência material e transferência verbal. No Gráfico 5, consta a distribuição percentual de todo os dativos, por tipo de verbo: complementos nulos num total de 1204, dos quais 611 ocorreram com verbos de transferência material, com um, percentual de 38,37\% e 593 com verbos de transferência verbal, num percentual de $37,24 \%$, totalizando um percentual de $75,62 \%$ de complementos nulos. Além dos nulos, observamos os seguintes complementos indiretos realizados fonologicamente: 227 objetos indiretos, representados por sintagmas nominais preposicionais, sendo 167 com verbos de transferência material e 60 com verbos de transferência verbal, num percentual de 10,48\% e 3, 68\% respectivamente. A terceira ocorrência foi dos pronomes tônicos anafóricos preposicionados, que perfizeram um total de 118 realizações, sendo 63 realizados com verbos de transferência material e 55 com verbos de transferência verbal, num percentual de 3,95\% e 3,45\% respectivamente. A realização menos significativa foi dos clíticos: 15 com verbos de transferência material e 28 com verbos de transferência verbal, num percentual de 0,94\% e 1,75\%, respectivamente.

No Gráfico 3, os dativos foram apresentados sob a perspectiva do tipologia semântica do verbo, enquanto no Gráfico 4 a perspectiva de apresentação é o tipo de dativo, com o registro da distribuição percentual desses dativos no Gráfico 5. 
A pouca ocorrência dos clíticos é algo observado em estudos anteriores. Mesmo tendo sido considerados também os clíticos Ihe(s) referentes à segunda pessoa, a sua realização foi muito pequena. A incidência dos verbos com interpretação semântica de transferência material superou um pouco as ocorrências dos de transferência verbal. Entre aqueles, a ocorrência maior foi do verbo dar e entre os de transferência verbal, do verbo dizer, que são os protótipos dentro dessas tipologias semânticas, conforme os exemplos em (1) e (2).

(1) Inf. - o diploma Ihe dá o pergaminho (Ihe=você) (Inq. 05).

(2) aí eu disse "Hernandes eles num vão querer não...". (Inq.02).

O verbo dar em (1) é semanticamente interpretado de transferência material, sendo o argumento interno objeto indireto interpretado como recipiente; em (2) o verbo dizer tem a interpretação de transferência verbal em que um agente animado transfere ao argumento interno objeto indireto, que tem conotação semântica de recipiente, uma informação, um conhecimento ou uma percepção.

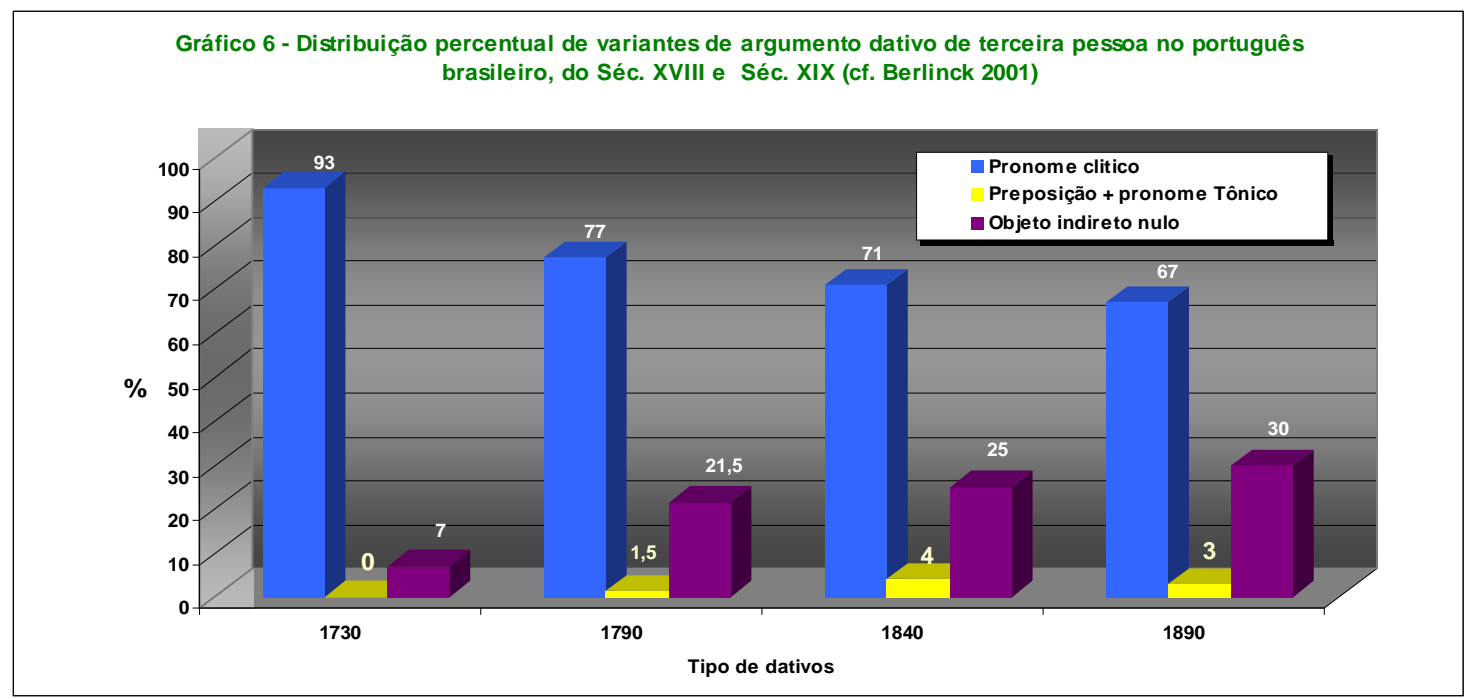

Fonte: Torres Morais e Berlinck (2006)

A comparação do Gráfico 5 em que consta a distribuição percentual de dativos do PBF com o Gráfico 6, que apresenta as ocorrências de dativos de terceira pessoa dos séculos XVIII e XIX Berlinck (2001), demonstra que os clíticos 
dativos de terceira pessoa vêm decrescendo ao longo dos anos, chegando à sua performance atual de inexistência, enquanto os nulos vão ganhando espaço. Se considerarmos que, no PBF, foram contabilizados percentualmente todos os clíticos Ihe(s), mesmo os referentes à segunda pessoa, podemos concluir que sua realização foi praticamente zero. Observa-se que, à proporção, que tais clíticos desaparecem, vão aumentando as formas alternativas para sua substituição. Dentre elas destaca-se a realização do objeto nulo, seguida do anafórico preposicionado, conforme se observa no Gráfico 4.

\subsubsection{Ocorrências de dativos nulos com verbos de transferência material}

Os dativos nulos do PB já foram estudados por Cyrino (1999). Essa autora assinala diferenças entre as realizações dos complementos nulos no PE e no PB, com relação aos contextos de ocorrência desses nulos, pois em PE existem restrições à realização de complementos nulos, nos chamados contextos de ilhas sintáticas. Por exemplo, numa oração adjetiva não é possível em PE ocorrer um objeto nulo, referido na oração anterior. Os objetos nulos analisados no PB se referem a qualquer tipo de objeto indireto, não realizado fonologicamente, tanto aqueles que podem ser recuperados no contexto sintático ou discursivo, como aqueles provenientes de verbos lexicalizados, conforme já referido.

Tabela 6 - Ocorrências do dativo nulo, com verbos de transferência material, por tipo de oração

\begin{tabular}{|c|c|c|}
\hline Tipo de oração & $\mathbf{N}^{\circ}$. de ocorrências & $\%$ \\
\hline Sentença Raiz & 146 & 23,9 \\
\hline Subordinada & 269 & 44,03 \\
\hline Segunda Coordenada & 76 & 12,44 \\
\hline Principal & 78 & 12,77 \\
\hline Primeira Coordenada & 42 & 6,87 \\
\hline Total & 611 & 100 \\
\hline
\end{tabular}

Fonte: Inquéritos do Porcufort, 1993-1994. 


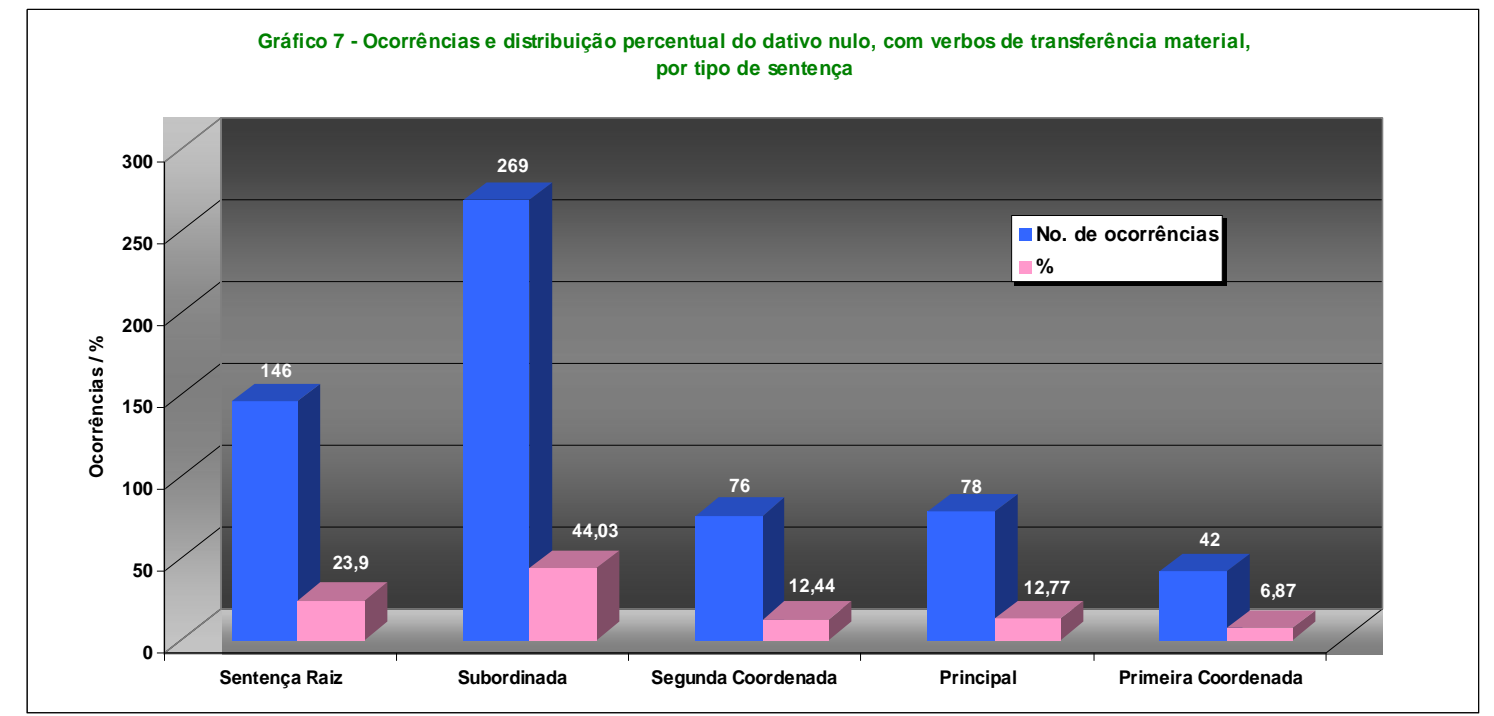

Fonte: Tabela 6.

Na Tabela 6 e no Gráfico 7, evidenciam-se os tipos de orações em que se realizam os objetos indiretos nulos com verbos de transferência material. As orações subordinadas apresentam uma maior porcentagem de realização: 44,03\% (269 ocorrências num total de 611), vêm, em seguida, as sentenças absolutas com 23,90\% de ocorrências (146 num total de 611), as principais com 12,78\% (78 ocorrências num total de 611), a primeira oração coordenada com 6,78\% (42 ocorrências num total de 611), e a segunda coordenada com 12,44\% (76 ocorrências num total de 611).

A análise que se depreende a partir dos dados é que o maior número de subordinadas se deve ao fato de que as pessoas entrevistadas são adultas e cultas; se fossem crianças ou analfabetas, fariam um discurso mais baseado na coordenação, com muito uso de então. Logo, o público alvo da pesquisa explicita mais o pensamento com sentenças complexas: causas, conseqüências, comparações; faz mais uso dos relativos e das formas nominais, o que torna viável mais sentenças encaixadas, conforme se observa nos exemplos abaixo:

(3) Inf. 2 - FIZ um ditado só de palavrinha BESta duma poesia que eu tinha dado... (Inq.16) 
(4) aTÉ a oitava série num me preocupo... de dar de maneira alguma... TEnho certeza que eu dou o recado... (Inq.16)

(5) Inf. 1 porque eu Acho que LÁ dão poucas cadeira... e...Conhecimento Dois... bem LÁ estão oferecendo... Epistemologia...(Inq.33)

(6) Inf. 1 ... mas a condição de ficar era só se:: ele passasse e ninguém pode ficar nessa... ne? nesse PROpósito né?... de deixar matricular:: e dar uma:.... promoção quando a criança num...(Inq.07

Em (3) e (4) temos o verbo dar, semanticamente interpretado de transferência material, em que ocorrem dativos nulos recuperados no contexto discursivo, pois sabemos que a referência é alunos. Em (5), o verbo oferecer é também interpretado semanticamente como de transferência material, pois há um agente que oferece algo (tema) ao argumento interno, o dativo nulo, recuperado no contexto discursivo. Em (6), ocorre uma sentença com o verbo ditransitivo dar semanticamente interpretado como de transferência material, cuja grelha temática é formada por um argumento externo (agente), um argumento interno (tema) e pelo argumento interno objeto indireto semanticamente interpretado como recipiente. $O$ verbo desta sentença sofre um esvaziamento lexical, concentrando-se a sua significação no termo promoção que, juntamente com o verbo, forma o deverbal promover. $\mathrm{O}$ argumento interno objeto indireto é nulo recuperado no contesto (criança).

\subsubsection{Ocorrências de dativos nulos com verbos de transferência verbal}

Na Tabela 7 e no Gráfico 8 observamos, por tipo de oração, como é a ocorrência dos objetos indiretos nulos com verbos de transferência verbal 
Tabela 7 - Ocorrência de dativos nulos, com verbos de transferência verbal, por tipo de oração

\begin{tabular}{|c|c|c|}
\hline Tipo de Oração & $\mathrm{N}^{\mathrm{o} .}$ de ocorrências & $\%$ \\
\hline Sentença Raiz & 74 & 12,48 \\
\hline Subordinada & 170 & 28,67 \\
\hline Segunda Coordenada & 42 & 7,08 \\
\hline Principal & 286 & 48,23 \\
\hline Primeira Coordenada & 21 & 3,54 \\
\hline Total & 593 & 100,00 \\
\hline
\end{tabular}

Fonte: Inquéritos do Porcufort, 1993-1994.

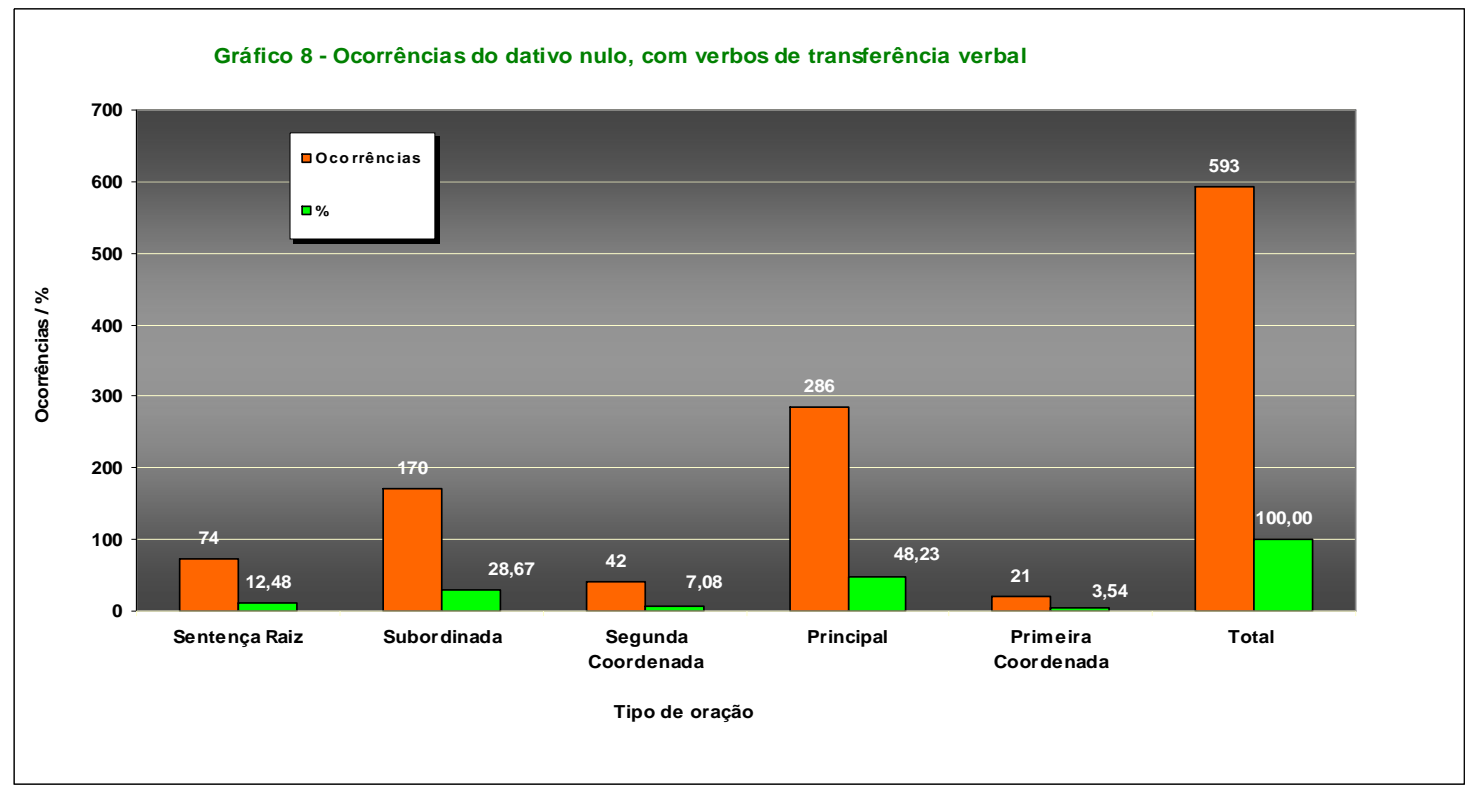

Fonte: Tabela 7

As orações principais tiveram um maior destaque com 48\% (286 em 593 ocorrências), seguidas das subordinadas com 28,67\% (170 sentenças em 593). Em seguida, aparecem as sentenças raiz, que perfazem 12,48\% do total (74 em 593) e, por fim, a primeira e a segunda coordenadas aparecem com os seguintes percentuais: 3,54\% (21 em 593) 7,08\% (42 em 593), respectivamente.

É possível que a maior ocorrência dos nulos nas orações principais deva-se ao fato de os verbos com interpretação semântica de transferência verbal favorecerem a realização de um CP (complemento representado por uma oração) como argumento interno-tema, sendo que a identificação do complemento nulo, às vezes, se acha aclarada em tal CP. Nos exemplos em (7) e (8), (9) e (10) 
percebemos a realização das orações encaixadas com os verbos de elocução perguntar e falar, dizer, com a realização do complemento nulo na oração principal. O exemplo em (11) apresenta também um verbo de elocução, mas o complemento nulo encontra-se na subordinada.

(7) num di/ ((riu)) ... perguntei se ele queria ir pra lá... aí ele pegou:: não:: (Inq.02)

(8) a Nádia lá no escritório... e FAlei né?... se ele num queria ir pra LÁ nã/ nã/ claro que eu num (Inq.02)

(9) o aluno no dia-a-dia né?... eh no dia que fosse passar a prova num dissesse que era prova né?... pra ver comé que SERIA né?.. (Inq.16)

(10) bem aí ele pegou e falou com o Paulo né?... disse que queria ir embora (inq 02)

(11) Inf. 2 - TENta escutar o que vou dizer (Inq 11)

Os objetos nulos com verbos de transferência verbal em orações coordenadas aparecem em menor quantidade provavelmente, pela própria estrutura dos verbos de elocução, conforme já ressaltado.

As sentenças nos exemplos em (6), (7), (8), (9) e 10 realizam-se com verbos de transferência verbal, em que um argumento externo (agente) transfere um conhecimento ou uma percepção (tema) ao argumento interno (objeto indireto) com a interpretação semântica de recipiente, nulo recuperado no contexto.

Curiosamente, dentre essas sentenças apresentam-se 4 casos em que 0 dativo nulo corresponde à terceira pessoa (sentenças de 7 a 10) e somente uma sentença (11) em que o nulo se refere à segunda pessoa (tu), numa evidência de que em contextos em que o the se referiria à terceira pessoa, a principal estratégia de substituição desse Ihe é o uso dos complementos nulos. 
O verbo ditransitivo em (9), disse tem a interpretação semântica de transferência verbal. $O$ argumento externo (sujeito) agente é nulo recuperado no contexto. $\mathrm{O}$ argumento interno objeto indireto também é nulo recuperado no contexto da oração anterior (Paulo). Esse argumento tem a interpretação semântica de recipiente, ou seja, é alguém que toma posse (recebe) a informação veiculada pelo agente, razão por que em tais contextos, tanto o agente como 0 argumento interno Ol são semanticamente +animados.

No exemplo em (11), o verbo dizer é semanticamente interpretado como um verbo de transferência verbal, cuja grelha temática está constituída por um argumento externo nulo, por um argumento interno (tema) e por um argumento interno objeto indireto nulo. Em tal sentença, o uso da forma imperativa tenta na oração principal, referente à segunda pessoa, poderia sugerir que teríamos, na oração encaixada, o clítico te ao invés de lhe, pois percebemos que, nesta sentença, o objeto nulo não se refere à terceira pessoa, mas à segunda pessoa, algo constatado em todo o corpus do PB de Fortaleza. Como a uniformidade de tratamento no PB e também no PBF não é muito rígida, existe a possibilidade de que a forma não explicitada seja realmente the e não te.

\subsubsection{Ocorrências do clítico dativo com verbos de transferência material}

A Tabela 8 apresenta as ocorrências dos clíticos com verbos de transferência material e, no Gráfico 9, podemos verificar a sua distribuição percentual.

Tabela 8 - Ocorrências do clítico dativo com verbos de transferência material, por tipo de oração

\begin{tabular}{|c|c|c|}
\hline Tipo de Oração & Ocorrências & $\%$ \\
\hline Sentença Raiz & 2 & 13,33 \\
\hline Subordinada & 9 & 60,00 \\
\hline Segunda Coordenada & 2 & 13,33 \\
\hline Principal & 2 & 13,33 \\
\hline Primeira Coordenada & 0 & 0,00 \\
\hline Total & 15 & 100 \\
\hline
\end{tabular}

Fonte: Inquéritos do Porcufort, 1993-1994. 


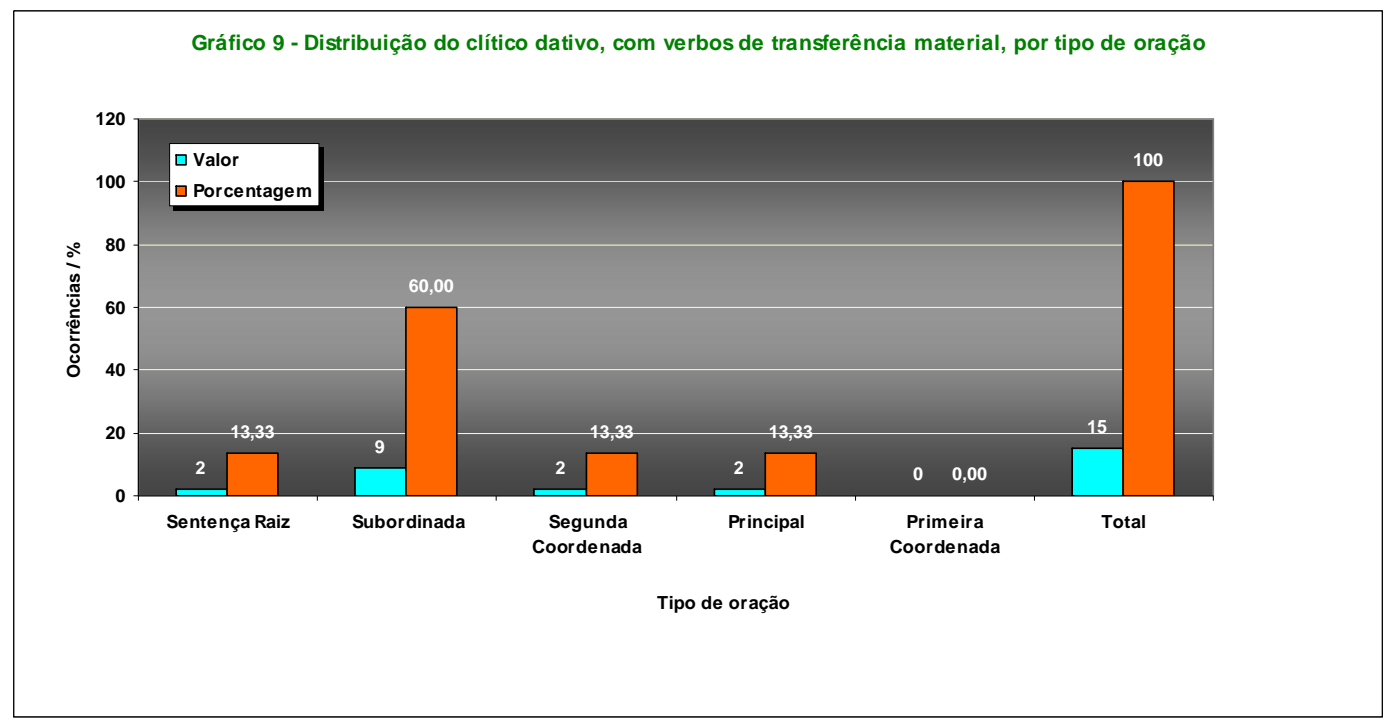

Nestes resultados, percebemos a predominância das orações subordinadas com 60\% (9 sentenças de um total de 15). Em seguida, aparecem as sentenças raiz, as segundas coordenadas e as orações principais com o mesmo percentual 13,33\% (2 ocorrências de cada tipo, no total de 15 sentenças). Não houve ocorrência de clíticos na primeira coordenada.

No Gráfico 9, vê-se uma das características atuais da linguagem falada, que é a quase ausência de clíticos. Mesmo quando eles aparecem, referem-se, em sua maioria, ao interlocutor, não sendo, portanto, um oblíquo de terceira pessoa. Vejamos alguns exemplos retirados do corpus com os clíticos em referência à segunda pessoa, realizados em orações subordinadas.

(12) Inf. 1- exatamente... agora eu não sei você já deve ter visto... um trabalho MEU... aliás até um projeto de monografia sobre Renovação Carismática Católica... num sei se eu.. Ihe Ihe emprestei ( ) (Inq 33)

(13) Inf. 1- eu também acho que mudou para pior SAbe?... PRA Ihe dar um exemplo... eu vou ao Liceu (Inq. 48)

(14) Inf. 2- é parece a idéia dum negócio mesmo me dê me dê isso que eu Ihe dou: (Inq. 33) 
Os exemplos (13) e (14) confirmam que a maioria das sentenças indicativas de transferência material são realizadas com o verbo dar.

A realização do clítico the no PBF ocorre, em sua maioria, em referência à segunda pessoa do singular, conforme o comprovam os exemplos relacionados em (12), (13) e (14).

No exemplo em (12), ocorre o clítico the com o verbo de transferência material emprestar, mas, não se realiza na sentença uma operação reversa conforme referida em Berlinck (1996,p.129), como se observa muitas vezes na fala espontânea de alguns paulistas: Emprestei o livro do José tendo o do José um caráter de fonte/origem. Na sentença (12), o objeto indireto do verbo emprestar tem realmente a interpretação semântica de recipiente, pois realmente o argumento externo sujeito transfere alguma coisa ao argumento interno objeto indireto e não o contrário como ocorreria se fosse empregada a preposição de em que a posse seria do argumento externo. Os falantes do PBF usam o verbo emprestar, geralmente, na acepção de um sujeito possuidor de algo que passa esse algo ao argumento interno objeto indireto. Quando querem dizer o contrário, ou seja, que a posse está com o argumento externo (sujeito), usam a construção: "Tomei emprestado".

\subsubsection{Ocorrências do clítico dativo com verbos de transferência verbal}

A Tabela 9 apresenta as ocorrências e o percentual de realização do clítico Ihe, com verbos de transferência verbal, por tipo de oração; o Gráfico 10 demonstra a distribuição percentual desses clíticos, também por tipo oração.

Tabela 9 - Clítico dativo com verbos de transferência verbal, por tipo de oração

\begin{tabular}{|l|r|r|}
\hline \multicolumn{1}{|c|}{ Tipo de Oração } & \multicolumn{1}{|c|}{ Ocorrências } & \multicolumn{1}{c|}{$\%$} \\
\hline Sentença Raiz & 2 & 7,14 \\
\hline Subordinada & 14 & 50,00 \\
\hline Segunda Coordenada & 2 & 7,14 \\
\hline Principal & 10 & 35,71 \\
\hline Primeira Coordenada & 0 & 0,00 \\
\hline
\end{tabular}




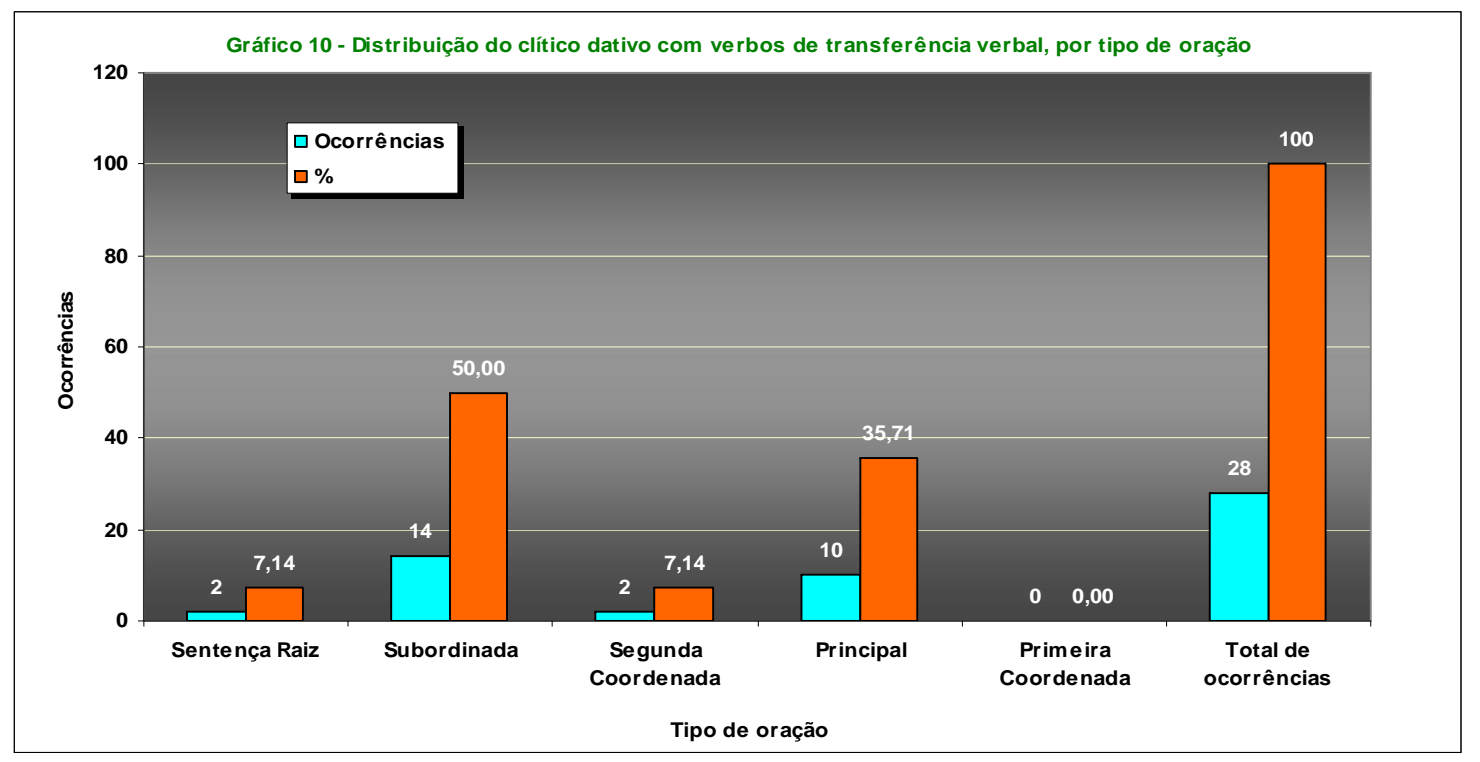

Verificamos que, com verbos de transferência verbal, a realização dos clíticos ocorreu mais em orações subordinadas, que apresentaram um percentual de $50 \%$ (14 em 28). As principais vêm em segundo lugar, com um percentual de 35,71\% (10 em 28); a segunda coordenada exibe um percentual de 7,14\% (2 em 28), tendo a sentença raiz o mesmo percentual. Não houve ocorrência desse clítico nas primeiras coordenadas. O gráfico confirma mais uma vez o pouco uso do clítico Ihe.

Se considerarmos que todos os clíticos - tanto da segunda como da terceira pessoa - foram incluídos no total de ocorrências, os resultados acabam por confirmar a hipótese (já analisada em outros estudos) de que sua realização é mínima, quase inexistente, especialmente no que se refere à terceira pessoa. (ver seção 3.3.10).

Exemplos de clíticos com esses verbos, retirados do corpus:

(15) EU or... PAULO vamo/ mexer nesse computador" o Paulo ele dormia na aula... EU $L H E^{*}$ [juro, recuperado no contexto] [JU/ NA A::ULA ( ${ }^{*}$ Ihe $=2^{a}$ pessoa) (Inq. 2)

(16) Inf. 1 - ...pronto era sobre isso que eu queria Ihe falar né? Inf. 2 - que que ficou acertado?( Ihe $2^{\mathrm{a}}$ pessoa) (Inq.7)

(17) carro ... e NUM DESse /tava esse rapaz que eu Ihe disse (Inq.11) 
(18) Inf. 2 - então mas eu aí aí é onde eu Ihe pergunto a Justiça ... a Justiça não a LEi ... é para ...o pobre ou para o rico? ... a lei (Inq. 11

(19) num... quando você diz assim me DÊ isso que eu:.... Ihe prometo fazer aquilo...(Inq.33)

As sentenças de (15) a (18), realizadas com clíticos num contexto de verbos de transferência verbal confirmam a inexistência dos clíticos dativos de terceira pessoa, pois os exemplos relacionados foram realizados todos com o clítico referente à segunda pessoa, ou seja, ao interlocutor. A sentença em (19) encerra um caráter de indefinição, pois se refere a uma terceira pessoa, que pode ser qualquer pessoa e não alguém especificamente.

A pouca produtividade dos clíticos de terceira pessoa observada no PBF corrobora as conclusões de Torres Morais e Berlinck (2001) ao estudar a sintaxe dos clíticos no PB, de que no conjunto das reanálises (que refletem a perda da expressão morfológica do dativo no PB) está incluída a baixa produtividade dos clíticos:

Em (18), o verbo perguntar, semanticamente interpretado como de transferência verbal, apresenta em sua grelha temática a seguinte configuração: 0 argumento externo -agente (eu), o argumento interno objeto direto - tema representado pela oração encaixada e o argumento interno objeto indireto o oblíquo the em referência à segunda pessoa, com interpretação semântica de recipiente.

O pouco uso do clítico de terceira pessoa, verificado no discurso dos falantes do PBF, sinaliza, como já explicitamos no Capítulo 2, que tais formas não fazem mais parte da gramática interna do falante do PBF. São, portanto, aquisições escolares, que vão ser utilizadas em contextos específicos e formais. Freire (2005) apresenta esse mesmo ponto de vista sobre a aquisição e a realização de tais clíticos. Para esse autor, o uso do clítico de terceira pessoa no PB é uma aquisição escolar, que se manifesta somente em contextos associados a maior grau de formalidade. 


\subsubsection{Dativos representados por sintagmas preposicionais introduzidos por $a$, por para e sem preposição, com verbos de transferência material}

Os dativos realizados com sintagmas preposicionais em PBF são realizados com as preposições a e para ou ainda, sem auxílio de preposição, como no inglês ou como nas realizações verificadas no PB na Zona da Mata de Minas (corpus estudado por Scher,1999).

A Tabela 10 identifica o tipo de oração em que se dá a ocorrência desses complementos, especificando o tipo de preposição usada bem como a sua omissão. O Gráfico 11 apresenta os sintagmas preposicionais enfocando as preposições que introduzem tais complementos, com as respectivas orações e o gráfico 12 apresenta o seu percentual de realização.

Tabela 10 - Ocorrências de sintagmas preposicional e nominal com verbos de transferência material com para, com a e sem preposição, segundo o tipo de oração

material com para, com a e sem preposição, segundo o tipo de oração
\begin{tabular}{|l|c|c|c|c|c|c|}
\hline \multicolumn{2}{|c|}{ Tipo de Oração } & \multicolumn{2}{c|}{ com para } & \multicolumn{2}{c|}{ com a } & \multicolumn{2}{c|}{ sem preposição } \\
\hline & Ocorrências & $\%$ & Ocorrências & $\%$ & Ocorrências & $\%$ \\
\hline Sentença Raiz & 19 & $11,31 \%$ & 11 & $6,55 \%$ & 2 & $1,19 \%$ \\
\hline Subordinada & 34 & $20,24 \%$ & 34 & $20,24 \%$ & 6 & $3,57 \%$ \\
\hline Segunda Coordenada & 9 & $5,36 \%$ & 11 & $6,55 \%$ & 2 & $1,19 \%$ \\
\hline Principal & 13 & $7,74 \%$ & 10 & $5,95 \%$ & 5 & $2,98 \%$ \\
\hline Primeira Coordenada & 4 & $2,38 \%$ & 0 & $0,00 \%$ & 2 & $1,19 \%$ \\
\hline Total & 79 & & 66 & & 17 & \\
\hline
\end{tabular}

Fonte: Inquéritos do Porcufort, 1993-1994 


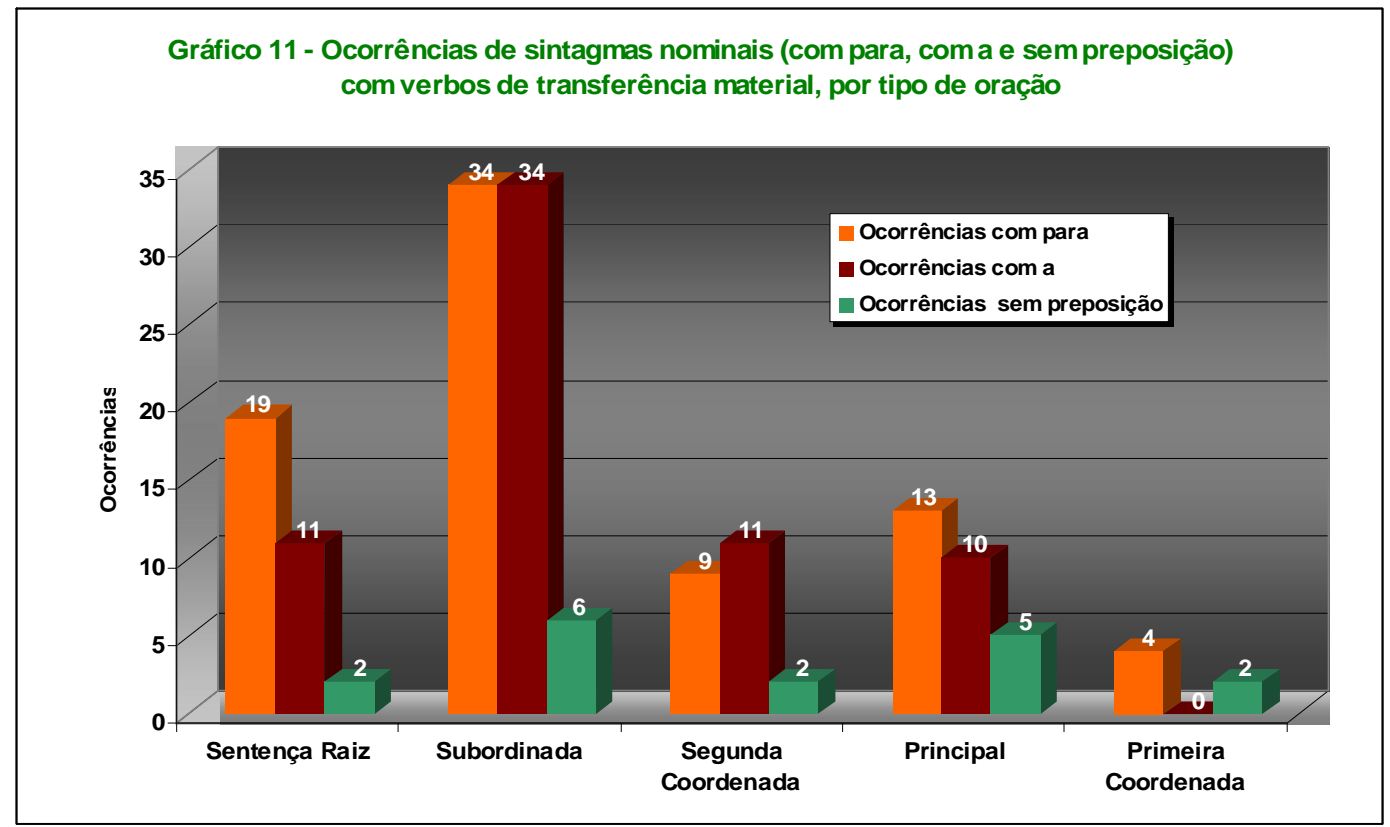

Fonte: Tabela 10

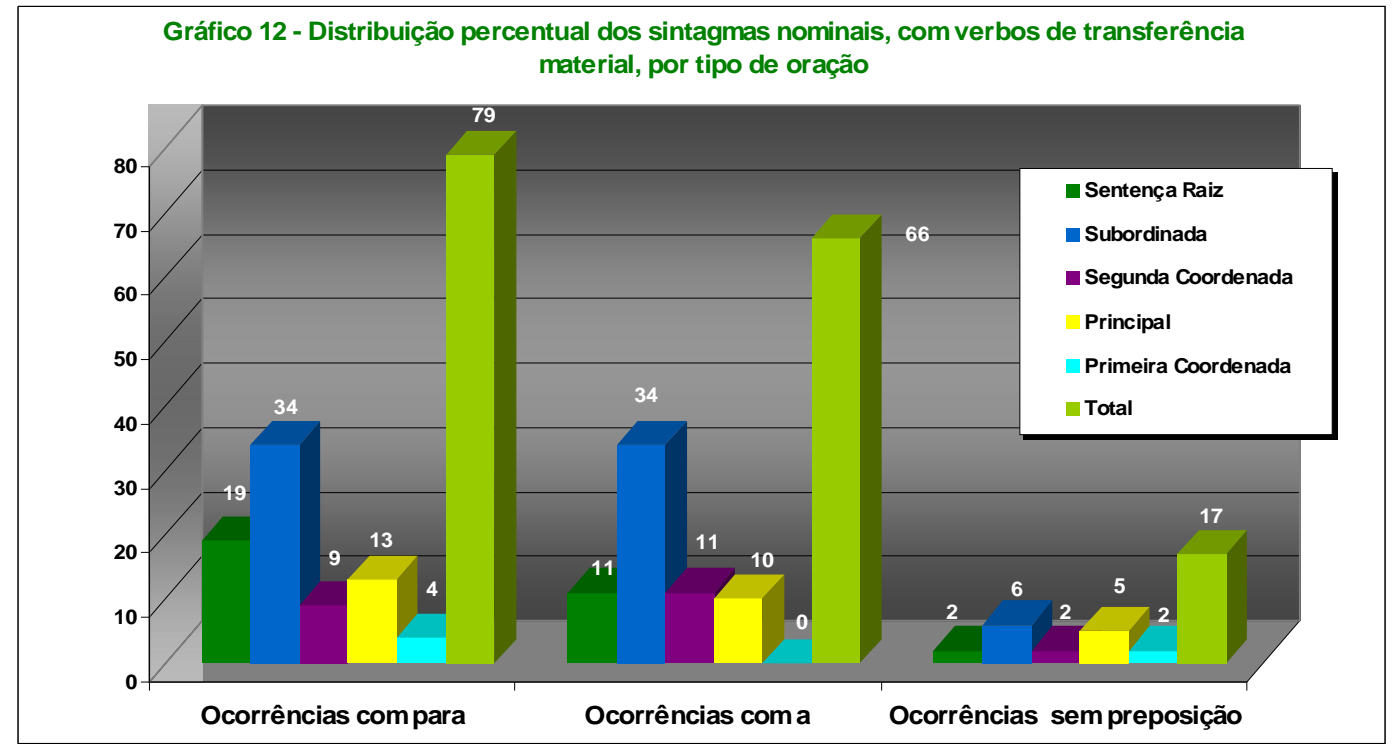

Fonte: Tabela 10

Examinando-se a tabela 10 e o gráfico 11, percebe-se, por exemplo, que a preposição para e a preposição a tiveram o mesmo número de realizações nas orações subordinadas. Nas sentenças raiz, nas orações principais e nas primeiras coordenadas, o uso de para suplantou o uso de a. Somente nas segundas coordenadas, houve uma maior realização da preposição $a$. No gráfico 10 , o 
enfoque apresentado é o tipo de oração em que se deu a realização da preposição a e da preposição para.

O Gráfico 12 apresenta o percentual de realização dos sintagmas preposicionais em relação às orações em que ocorreram. Percebe-se, mais uma vez, o elevado número de objetos indiretos em orações subordinadas 44\% (74 em 162). Em seguida, vêm as sentenças raiz, com 19,05\% de ocorrências (32 em 162). As orações principais e as segundas coordenadas tiveram o mesmo percentual 16,67 (28 em 162) e as primeiras coordenadas perfizeram um total de $3,57 \%$ de ocorrências (6 em 162).

Com esses verbos, houve 167 ocorrências de objeto indireto com sintagmas nominais (conforme apresentado na Tabela 5). $\mathrm{Na}$ tabela 10, só aparecem 162 ocorrências, porque não computamos os cinco casos de uso de outras preposições: em, com, de por se tratar de um número muito pouco significativo de ocorrências.

Das 162 ocorrências consideradas, 45,66\% (79 em 167) são introduzidas pela preposição para, enquanto 41,61\% (72 em 162) pela preposição a, 9,82\% (17 em 162) sem preposição e 05 ocorrências com outras preposições: em, com e de, perfazendo estas últimas um total de 2,89\%.

A grande ocorrência de sintagmas nominais dativos deve-se ao fato de terem sido considerados todos os sintagmas do corpus que apresentavam as características de argumento interno de um verbo ditransitivo, não importando se eram usados como estratégia de substituição aos clíticos ou não. Vale ressaltar que, se houve esse tipo de ocorrência, foi insignificante ou imperceptível. Outra consideração a ser feita é que um dos objetivos do estudo foi observar a preposição introdutória dos dativos, portanto não se poderia deixar de lado qualquer ocorrência esclarecedora nesse sentido.

Vejamos alguns exemplos do corpus, em que aparecem sintagmas nominais, com verbos de transferência material, introduzidos pela preposição para.

(20) Inf. 2 - pequenos negócios assim como ninguém você negocia com eles... /cê pede prum menino daquele lavar um car::ro... \{ou (então) (Inq. 07) 
(21) Inf. 1 ... o novo GOLpe da praça é o seguinte ... eu passo um cheque pro senhor certo?.. (Inq. 11)

(22) Inf. 1 eh... dá pro... dá dinheiro p/os pobre... distribuir esmolas... então... /tá mais dentro... do espírito da igreja... Inf. 1 na minha:: na minha sala... eu tanto dava Teologia da Li\{bertação (Inq. 33)

(23) quando Aristóteles escreveu A Política... já o o governo dele pagava três óbulos... pro cidadão comparecer à reunião da praça... pra homologar as decisões do presidente da (Inq. 10)

Observem-se alguns casos de objetos indiretos introduzidos por outras preposições:

(24) ...de vim aqui p/o colégio eu passei lá... quase todo dia eu passo lá pa/ dar um cheirinho na mamãe no... falar com o papai... dar um beijo nele também quer dizer... eh::... bem Inq. 34

(25) Inf. e eu fui a ela né?... pedi informações de outras pessoas que fizeram operação NÃO da vista mas do do busto ((voz Inq. 13

(26) são... deputado etc. que adquire rádio vende pra um:: compra de outro... quer dizer essa concessão do rádio no Brasil deu Inq. 15

(27) criança (fe/)...((latidos de cão)) primeiro pedia a permissão dos pa::is pra fazer né?... Inq. 21 ( tenho dúvida sobre a classificação desse dos pais)

Vale fazer algumas observações sobre os complementos dativos introduzidos por outras preposições. Em (24), o verbo dar não tem a conotação semântica de transferência material. Sabemos que se trata de um dativo porque podemos substituir dar um beijo nele, por dar-lhe um beijo. Embora, em PBF seja impossível dizer dar um beijo a ela ou dar um beijo pra ela, com a acepção de beijar. 
Em (25) e (27), o verbo pedir tem a conotação semântica de transferência, mas o argumento interno dativo é considerado fonte e não recipiente, como ocorre em muitos desses verbos. Os verbos vender e comprar em (26) trazem também argumentos internos dativos significando fonte.

O emprego da preposição de em argumentos internos dativos (objeto indireto) em substituição à preposição $a$, não é uma realização muito comum na sintaxe do falante cearense. As realizações do corpus levam à confirmação de tal idéia, demonstrando uma aproximação maior com a sintaxe lusitana, conforme observaremos na análise do capítulo 4, que trata do CRPC. Quando dizemos, por exemplo, pedi o carro do José para dar uma volta, o complemento do José tem a conotação semântica de posse; é possível, inclusive, a construção pedimos o carro do José à mãe dele, sendo a expressão à mãe dele, o argumento interno objeto indireto.

A alternância a/para, no $P B F$, se aproxima do resultado obtido por Torres Morais e Berlinck (2002) em pesquisa feita em anúncios de jornal dos últimos cinco anos do século XIX. Se levarmos em conta que os contextos geográficos e lingüísticos são outros, até que há uma aproximação bem razoável entre os dois resultados, especialmente se considerarmos que os anúncios em questão não contavam, seguramente, com o percentual de $10 \%$ de ausência da preposição. O certo é que ambas as pesquisas sinalizam para uma gradual substituição da preposição a pela preposição para. Considerando que o cearense, como já foi ressaltado, é bem mais conservador e, conseqüentemente mais próximo da sintaxe lusa, podemos propor que tais mudanças atingem o PB em todo o território nacional, conforme já referido.

Detectamos que há uma porcentagem um pouco maior do uso da preposição para (45\%) no objeto indireto, comparado com a porcentagem de $41 \%$ de uso da preposição a. Isso pode significar duas coisas: ou no PBF, diferentemente do PE, as duas formas concorrem paralelamente, (até com maior incidência do para) e não, como assinala Bechara (2003) esporadicamente; ou, então, o PBF também, como argumentam Morais e Berlinck (2006) sobre o PB, está perdendo a capacidade de expressar morfologicamente o caso dativo. 
Torres Morais e Berlinck (2004, p. 12) ressaltam o uso da preposição a na fala dos curutibanos e dos fortalezense, confrontando os dados de pesquisas realizadas por Berlinck e Scherre \& Salles:

[...] Berlinck encontrou apenas 6,5 de casos de objeto indireto introzido pela preposição a em dados da língua falada de curitibanos. Por sua vez, Salles \& Scherre (2003) obtêm um índice bem mais elevado de uso dessa preposição na fala de brasileiros habitantes de Fortaleza, com idade entre 18 e 25 anos e nível de instrução médio - 33\% (25 casos em 76).É importante destacar que as próprias autoras consideram que nessa região a eliminação de a é menos radical.

Mateus et al. (2003, p. 289) consideram como condição sine qua non para a realização do objeto indireto no $\mathrm{PE}$, a presença da preposição a. Para elas, a sentença (26), se for realizada como em (27), não haverá objeto indireto e, sim complemento oblíquo.

(28) A Maria deu [uma pintura] od [às estantes] oi

(29) A Maria deu [uma pintura] od [nas estantes] obl

Aplicando ao PBF a lógica usada por de Mateus et al (2003) em relação ao $\mathrm{PE}$, não haveria objeto indireto em tais variedades, mesmo com complementos mais animados, pois de acordo com estudos do PBF, a preposição para foi mais realizada do que a preposição $a$, havendo possibilidade de permuta de uma pela outra em todos os contextos. Ocorrem, nesse corpus, exemplos da comutação a/para, por um mesmo falante, num mesmo momento, numa demonstração de que seu emprego é um tanto quanto livre, conforme se observa nos exemplos apresentados em (30) e (31)

De acordo com Torres Morais (2007), A substituição da preposição a pela preposição para em todos os contextos de fala do $\mathrm{PB}$, confirmam a idéia de que preposição a perdeu a capacidade de marcar o Caso dativo, ou seja, passou a ser uma preposição lexical, assim como a preposição para, sendo o complemento 
introduzido por tais preposições considerados como PP. Tal fato inviabiliza as construções de núcleo aplicativo no PB/PBF, por essa via.

(30) A eu perguntei ao Alexandre que é um engenheiro amigo amigo meu amigo da gente (Inq.02)

(31) (Inf. 1 - aí eu perguntei né? pro Alexandre ele Acha que o colorit quartz é mais barato eu (Inq.02).

(32) DÊ terra pro nordestino... dê... dê condição pra ele... tire os juros bancários... ajude a econo-mia nordestina a crecer (Inq. 17)

No exemplo em (32) temos um verbo ditransitivo com interpretação semântica de transferência material, em que há um argumento externo que tem um certo caráter de indefinição, podendo ser você, mas com emprego indefinido; um argumento interno, o DP tema - e um argumento interno, o PP objeto indireto pro nordestino, com conotação semântica de recipiente. Nessa estrutura, o agente transfere ao argumento interno objeto indireto algo material, que no caso seria representado pelo sintagma nominal terra.

(33) arrematava...TODAS as prendas que tinha ele arrematava...e doava \{pra igreja...né?...então ele num levava nenhuma ele (Inq.45)

No exemplo em (33), o verbo ditransitivo doar, semanticamente interpretado como de transferência material, possui a seguinte estrutura argumental: o argumento externo agente nulo (recuperado no contexto) e os dois argumentos internos: o tema (objeto direto) todas as prendas e o recipiente da ação, o objeto indireto pra igreja. Vemos que a expressão pra igreja está personificada, significando instituição, ou seja, as pessoas que fazem parte dela.

(32) Inf. ela ... eu tinha pedido o rapaz ... nove mil mas deixa esse che-que pra segunda-feira ... NÃO o Moacir ... 1 cabe-ça" (inq 11) 
Em (32), o verbo pedir, com interpretação semântica de transferência material, apresenta a seguinte configuração argumental: argumento externo sujeito $e u, o$ argumento interno tema - objeto direto nove mil e o argumento interno objeto indireto o rapaz. Tal argumento ocorre sem a presença da preposição, fato constatado também em estudos realizados com falantes do PB em outras regiões do Brasil. Nesta sentença, o argumento interno objeto indireto não é semanticamente interpretado como recipiente da ação, mas sim como fonte.

Em (35) ocorre o verbo ditransitivo trazer, semanticamente interpretado como de movimento psicológico, pois há uma aproximação abstrata entre duas entidades, conforme Berlinck (1999, p. 133).

(35) Inf. 1 - a chamada medida antipática ((ruído)) papai num traz benefício a nin \{guém (Inq 11)

A sentença (35) apresenta a seguinte estrutura argumental: o argumento externo sujeito medida antipática, o argumento interno objeto direto benefício e $o$ argumento interno objeto indireto a ninguém. $\mathrm{O}$ objeto indireto foi introduzido pela preposição $a$, que está em competição com a preposição para. $O$ verbo da sentença demonstra também um caráter de verbo leve, podendo ser substituído juntamente com o substantivo benefício, pelo deverbal beneficiar.

Embora este trabalho esteja centrado mais em verbos de transferência material e de transferência verbal, selecionamos as sentenças em que tais verbos aparecem e codificamos com M. M é o código de movimento psicológico.

Berlinck (1999) considera que o verbo trazer pode indicar movimento físico ou movimento psicológico.

(36) Inf. 2 - e é incrível E. porque o ministro vem à... televisão todos os Dlas e PEde... aos consumidores que PArem de consumir porque o a inflação vai baixar... tudo bem a gente (Inq. 28) 
Em (36), o verbo ditransitivo pedir, com interpretação semântica de transferência material, tem sua grelha temática constituída pelo argumento externo $\mathrm{O}$ ministro, pelo argumento interno objeto direto, representado pelo $\mathrm{CP}$ que parem de consumir, e pelo argumento interno objeto indireto aos consumidores, que tem a conotação semântica de fonte. (Berlinck, 1999, p.129-131).

\subsubsection{Dativos de terceira pessoa realizados com sintagmas nominais introduzidos pelas preposições a e para ou sem preposição com verbos de transferência verbal}

A Tabela 11 traz as ocorrências de sintagmas nominais com verbos de transferência verbal, segundo a preposição e por tipo de oração.

Os Gráficos 13 e 14 apresentam as ocorrências do objeto indireto realizado com sintagmas nominais preposicionais introduzidos por a ou para, ou com omissão da preposição., com verbos de transferência verbal .

O Gráfico 15 apresenta as mesmas ocorrências, com ênfase para a distribuição por preposição (a ou para) ou pela sua ausência, com vistas a proporcionar melhor visualização do fenômeno alternância a/para.

Tabela 11 - Ocorrências de sintagmas nominais com verbos de transferência verbal, segundo a preposição e por tipo de oração

\begin{tabular}{|l|r|r|r|}
\hline \multicolumn{1}{|c|}{ Tipo de Oração } & \multicolumn{3}{|c|}{ No. de Ocorrências } \\
\hline Sentença Raiz & \multicolumn{1}{|c|}{ com para } & \multicolumn{1}{c|}{ com $\mathbf{a}$} & sem preposição \\
\hline Subordinada & 1 & 6 & 0 \\
\hline Segunda Coordenada & 11 & 3 & 6 \\
\hline Principal & 4 & 3 & 4 \\
\hline Primeira Coordenada & 14 & 6 & 2 \\
\hline & 0 & 0 & 0 \\
\hline
\end{tabular}

Fonte: Inquéritos do Porcufort, 1993-1994. 


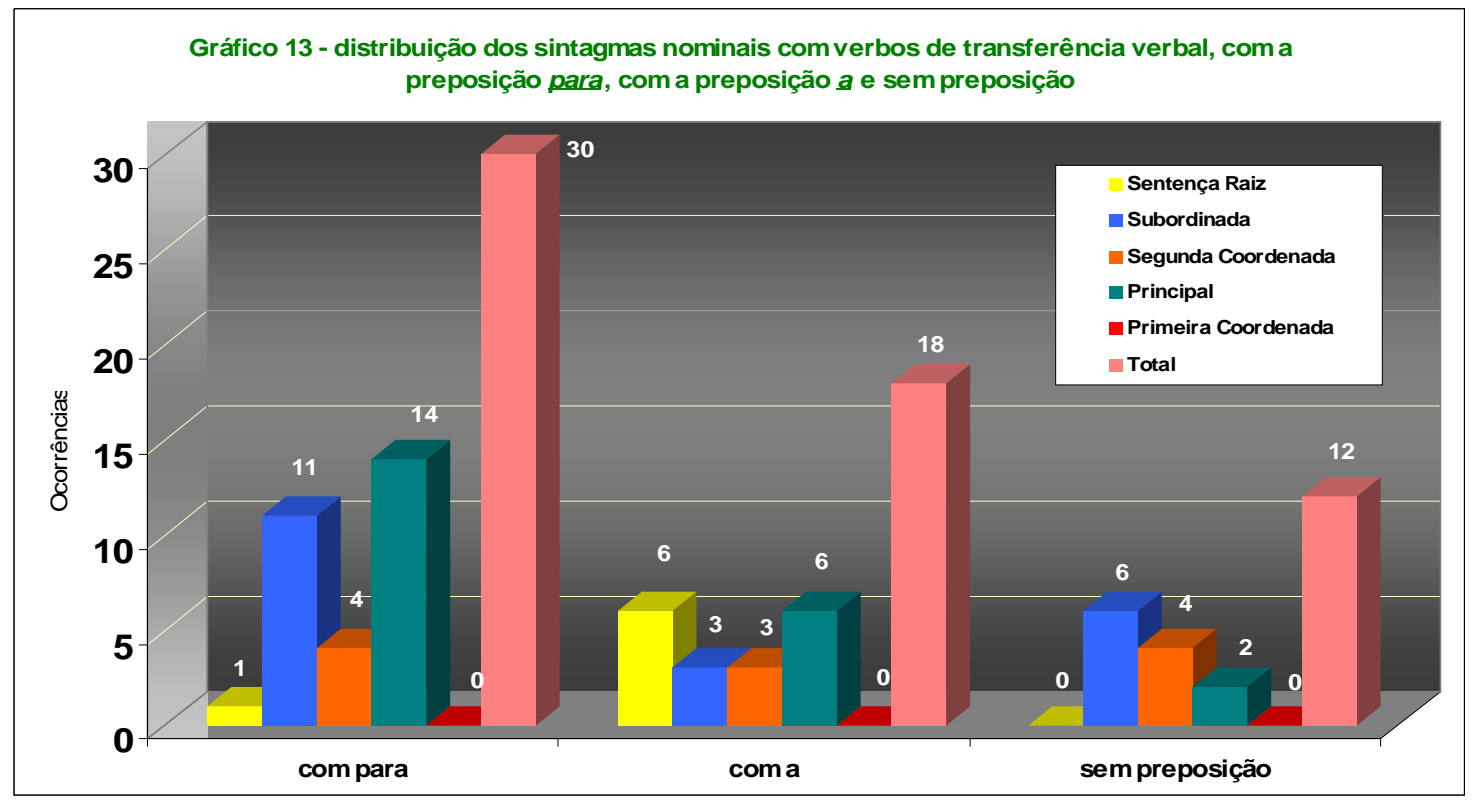

Fonte: Tabela 11

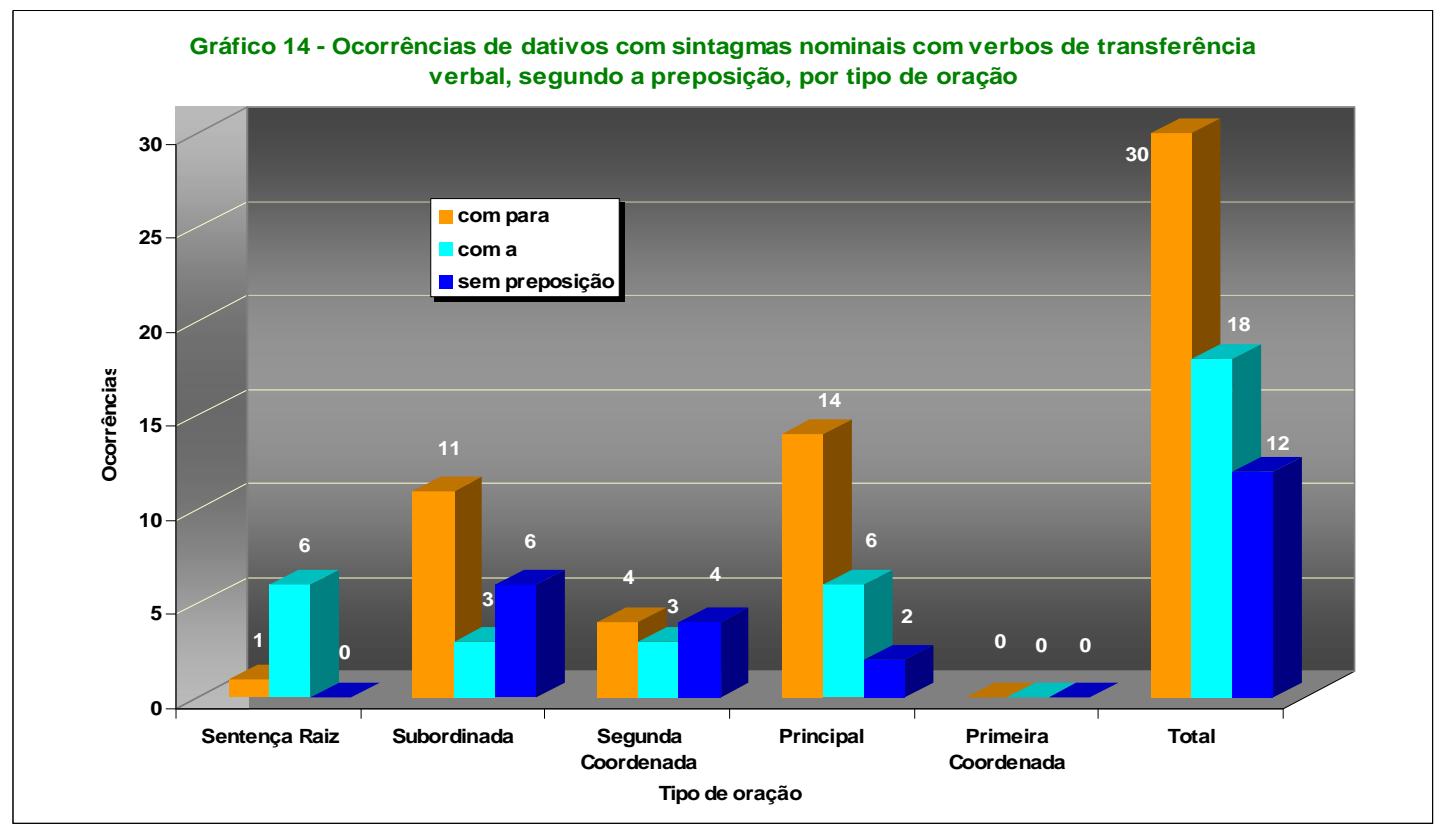

Fonte: Tabela 11 


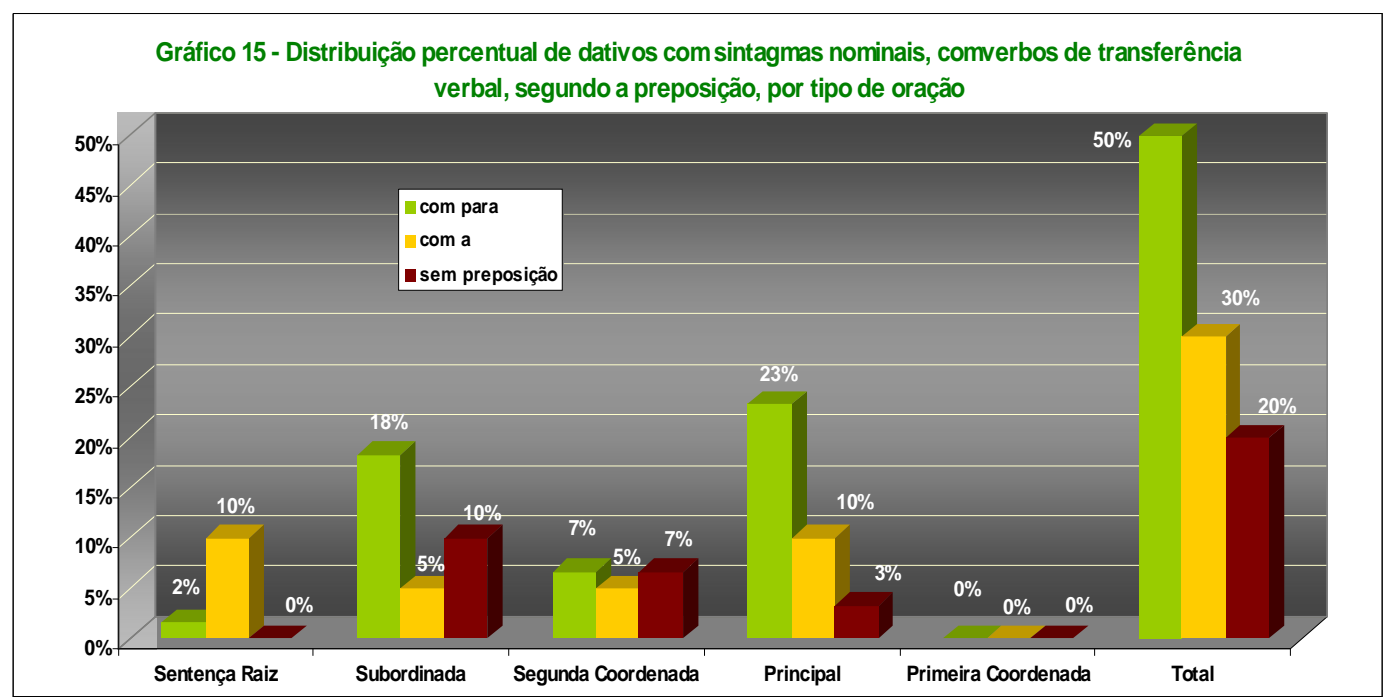

Fonte: Tabela 11

Verifica-se no corpus, nas realizações com verbos de transferência verbal, uma grande incidência do verbo dizer, com mais de $70 \%$ das realizações.

Percebe-se, no Gráfico 15, a preponderância do uso da preposição para em relação ao uso da preposição a. Num total de 60 ocorrências, há 30 ocorrências de objetos indiretos com a preposição para (50\%), 18 com a preposição a (30\%) e 12 (20\%) sem presença da preposição. Os objetos indiretos, nesse tipo de verbo, apareceram mais em orações principais 22 em 60 (36,6,\%), provavelmente por conta de a maioria desses verbos introduzir as encaixadas dos discurso direto ou indireto, conforme já referido. Os objetos indiretos nas orações subordinadas vêm em segundo lugar 20 em 60 (33,3\%), e finalmente os que se realizaram na segunda coordenada 11 em 60 (18,3\%). As realizações das sentenças raiz foram de 7 em 60 $(11,60 \%)$, sendo nula a realização desses sintagmas nas orações coordenadas iniciais.

Comprova-se assim a maior incidência da preposição para, com 50\% das ocorrências. O emprego do a está bem próximo da omissão da preposição, com uma diferença de $6 \%$ a mais, somente.

Vejamos alguns exemplos desses complementos encontrados no corpus: 
(37) a) Inf. 1 - num é?... num chega a ser uma sagração até o padre M.... na santa missa de domingo... ele explicou ao... o povo... aos paroquianos o que iri/ o que seRIA o que É... ser... (Inq. 39)

b) Inf. 1- aí eu aviso aqui ao pandeirista... eu digo "doutor doutor A. P.... doMINgo por motivo de força maior não vai haver o progra::ma coisa e tal" aí (Inq. 45)

(39) ...não MOStram aos alunos... não explicam pra eles... quais os objetivos... do ensino de língua estrangeira... porque basicamente eu digo aos meus alunos (Inq. 47)

(40) g) ...adiantado eu digo sempre para o meu aluno... é o objetivo cultural... o que é o (Inq. 47).

É interessante observar que, mais uma vez, o mesmo informante alterna o uso da preposição, conforme se observa em (39) e (40). É possível argumentar que o contexto sintático teve influência nessa realização, pois em (39) o sintagma nominal dativo com a preposição a ocorreu numa oração coordenada, enquanto que em (40), o sintagma realiza-se numa oração principal. Para se confirmar tal idéia é necessário que se faça maior estudo sobre tal assunto.

(39) Inf. 2- é como eu dizia eu estava dizendo pra minha cunhada que é professora de Letras... que no tempo que estudei no Hilza Diogo (Inq . 48.)

Em (39), o verbo ditransitivo dizer com a conotação semântica de transferência verbal apresenta em sua grelha temática: um argumento externo agente eu, um argumento interno objeto direto o CP que no tempo que estudei no Hilza Diogo - tema (objeto direto) e o argumento interno objeto indireto pra minha cunhada, semanticamente interpretado como recipiente.

(42) Inf. 2- porém um grande mestre nunca ensina aos seus alunos todos os truques.(Inq 45) 
Em (42) o verbo ditransitivo ensinar, semanticamente interpretado como de transferência verbal, apresenta a seguinte estrutura argumental: um argumento externo agente - um grande mestre, que transmite um conhecimento todos os truques (tema) ao argumento interno objeto indireto aos alunos, interpretado semanticamente como recipiente da ação.

\subsubsection{Dativos pronomes anafóricos preposicionados com verbos de} transferência material com a preposição para, com a preposição a ou com omissão da preposição, por tipo de oração

A realização de dativos com pronomes anafóricos é uma estratégia bastante produtiva, em substituição aos clíticos dativos de terceira pessoa (Ihe, Ihes) no PB. No PBF, essa realização ocorreu de forma moderada, se comparada às realizações observadas no gráfico da fala dos jovens curitibanos localizado em (3.3.1).Tais dativos ocorrem não só com a preposição a, mas também com a preposição para e até sem preposição.

A Tabela 12 traz as ocorrências de dativo representado por pronomes anafóricos tônicos com verbos de transferência material realizados com a preposição para, com a preposição a e com omissão da preposição. Observa-se ainda a distribuição percentual das preposições por tipo de oração.

Tabela 12 - Ocorrências de dativos realizados com pronomes tônicos anafóricos com verbos de transferência material, com a preposição para, com preposição a e sem preposição, por tipo de oração,incluindo distribuição percentual

\begin{tabular}{|c|c|c|c|c|c|c|}
\hline & $\begin{array}{l}\text { Com } \\
\text { para }\end{array}$ & $\begin{array}{c}\text { Com } \\
\underline{a}\end{array}$ & $\begin{array}{c}\text { Sem } \\
\text { preposição }\end{array}$ & $\begin{array}{l}\text { Com } \\
\text { para }\end{array}$ & $\begin{array}{c}\text { Com } \\
\underline{a}\end{array}$ & $\begin{array}{c}\text { Sem } \\
\text { preposição }\end{array}$ \\
\hline Sentença Raiz & 10 & 3 & 1 & 15,87 & 4,76 & 1,59 \\
\hline Subordinada & 10 & 9 & 0 & 15,87 & 14,29 & 0 \\
\hline Segunda Coordenada & 9 & 6 & 0 & 14,29 & 9,52 & 0 \\
\hline Principal & 5 & 3 & 1 & 7,94 & 4,76 & 1,59 \\
\hline Primeira Coordenada & 4 & 2 & 0 & 6,35 & 3,17 & 0 \\
\hline Total & 38 & 23 & 2 & 60,32 & 36,5 & 3,18 \\
\hline
\end{tabular}


O Gráfico 16 não teve como fonte realizações do PBF mas, realizações do PEUL que expressam o uso das preposições a e para em contextos com o verbo de transferência material dar.

Nos Gráficos 17, 18 e 19 estão representadas as realizações do PBF com pronomes anafóricos preposicionados como objetos indiretos em verbos de transferência material, com as preposições $a$, para e sem preposição.

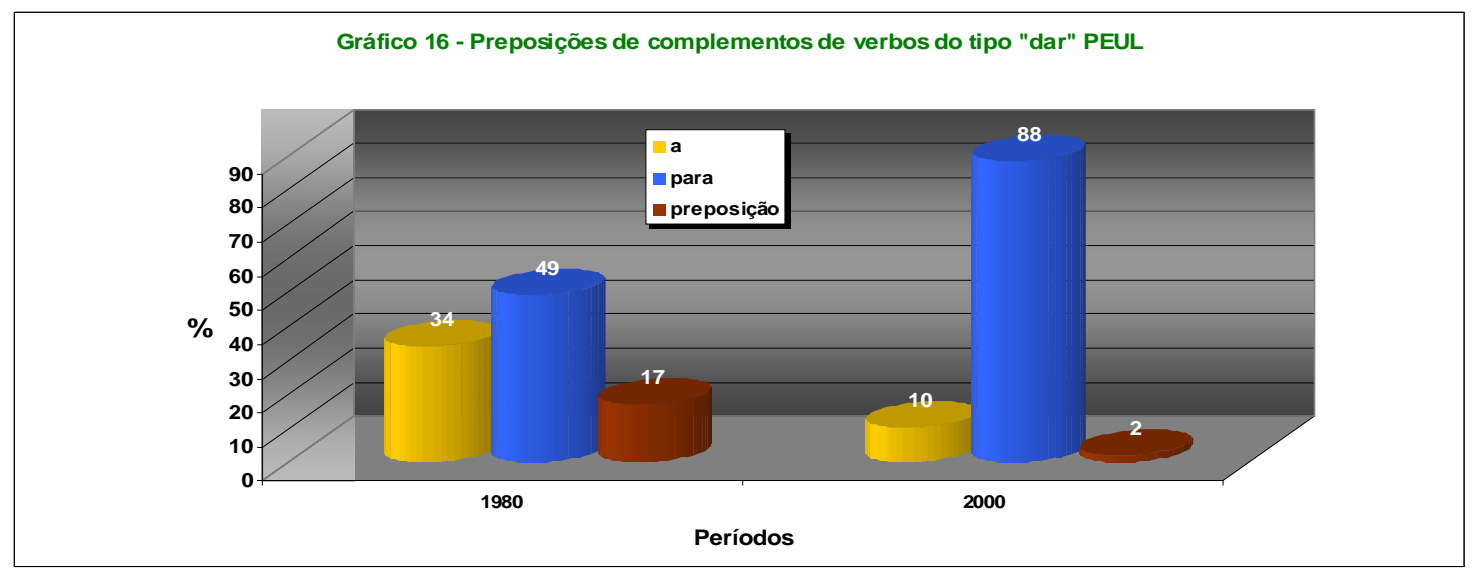

Fonte: Torres Morais e Berlinck (2002)

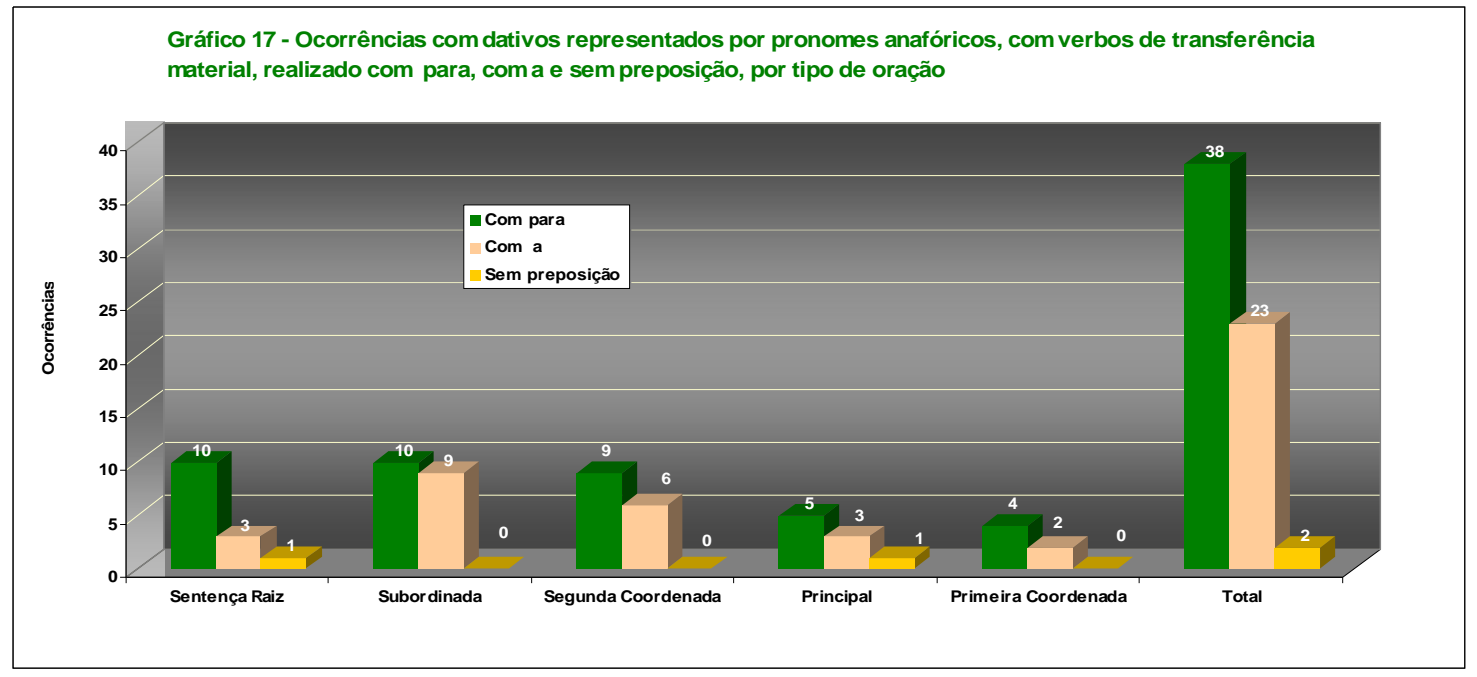

Fonte: Tabela 12 


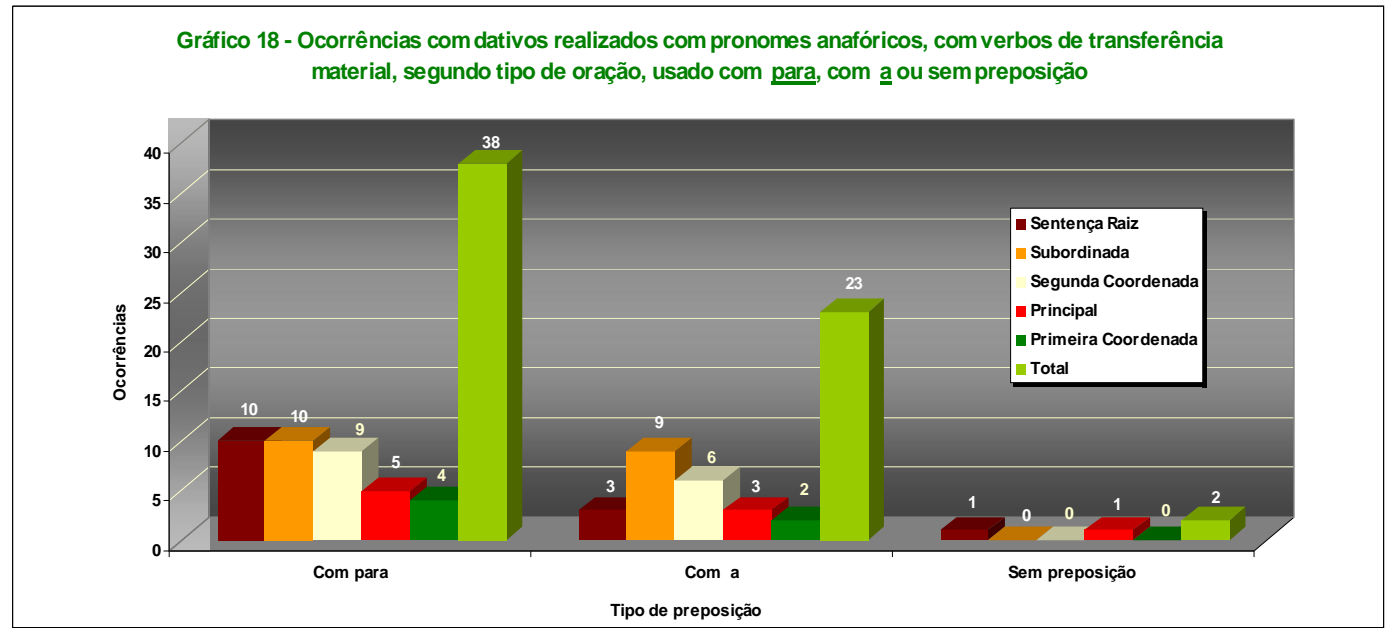

Fonte: Tabela 12

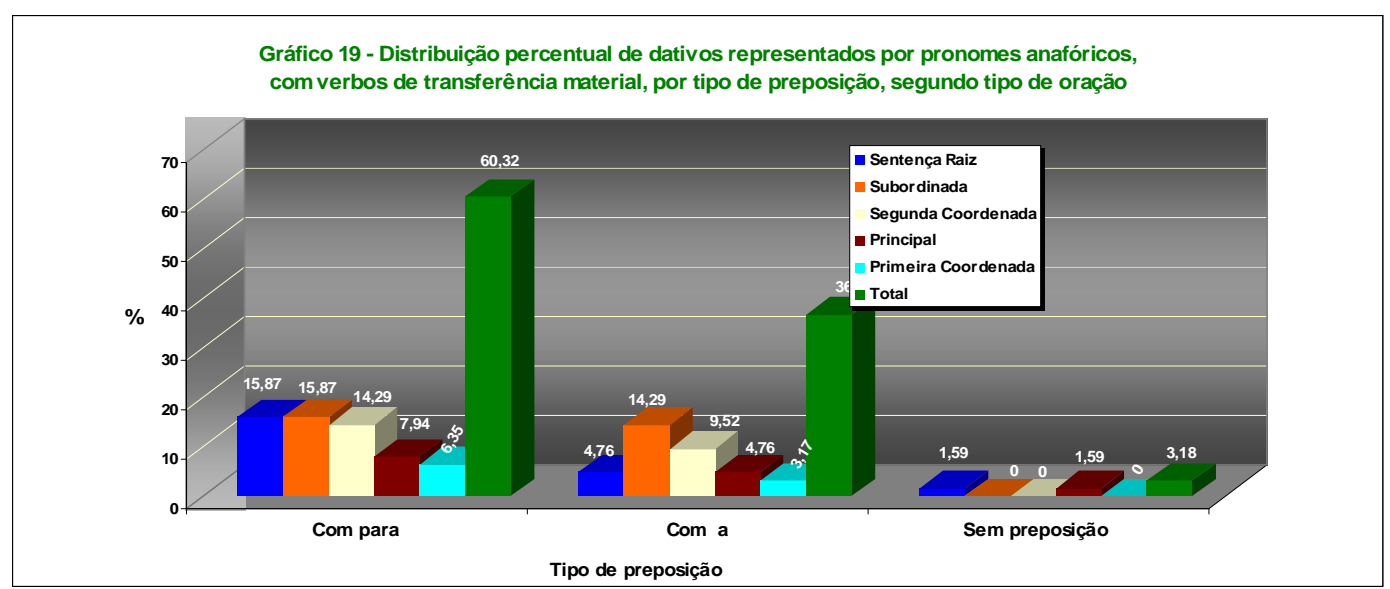

Fonte: Tabela 12

No Gráfico 17, o enfoque é dado ao tipo de preposição em que se realizam as sentenças. Observamos, através desse gráfico, a preponderância da preposição para em todos os tipos de sentenças. Ocorre também o uso da preposição a, que, embora em menor escala, pode significar que na região Nordeste tal preposição é mais realizada, especialmente se considerado em termos de alguns contextos nacionais em que tal realização é insignificante.

No Gráfico 18, o enfoque das realizações com os complementos dativos centra-se no ripo de oração em que se observa o uso da preposição novamente a grande incidência de complementos introduzidos pela preposição para, num total 60,31\% (38 em 63), a preposição a apresenta resultado inferior, com 36,50\% 
apenas (23 em 63) ocorrências, com uma diferença bem significativa. A omissão da preposição teve um percentual de 3,18\%, (2 em 63) das ocorrências.

O Gráfico 19 evidencia a distribuição percentual das preposições, por tipos de oração. Quanto à percentagem de ocorrência nas orações em que tais complementos se realizam, observamos que, nas sentenças raiz, há um percentual de 15,87\% de realizações com a preposição para, 4,76\% com a preposição a e 1,59\% sem uso de preposição; nas orações subordinadas, constata-se que os percentuais de realizações com para e a são quase equivalentes: $15,87 \%$ e $14,29 \%$ respectivamente; as segundas coordenadas apresentam um percentual de $14,29 \%$ de uso de para e $9,52 \%$ de uso da preposição a; nas orações principais constatam-se as seguintes realizações : 7,29\% de para, $4,76 \%$ de a e $1,59 \%$ de anafórico tônico sem preposição. As primeiras coordenadas apresentam um menor percentual inferior ao das outras orações: $6,35 \%$ da preposição para e $3,17 \%$ da preposição $a$.

Vejamos alguns exemplos que ocorrem no corpus:

(43) 0 psiquiatra e ele já tinha algumas noções sobre a terapia ocupacional e eu pedi muito ajuda... pra ele... pra (ele) sabe (Inq. 21)

(44) lá no CAMpo... que esse agricultor vai produ-ZIR... e reproduzir dando condições pra ele... sem juros... sem:: (Inq. 17)

(45) Inf. 1 - ninguém tem a obrigação de dar dinheiro a ele \{não (Inq. 11)

(46) DÊ terra pro nordestino... dê... dê condição pra ele... tire os juros bancários... ajude a econo-mia nordestina a crescer (Inq. 17)

(47), Lúcia o que que ela poderia dar... /tô pensando em pedir [ ] ela os refrigerantes...(Inq.07)

No exemplo em (45), o verbo ditransitivo dar, com interpretação semântica de transferência material, satura a sua grelha temática com os seguintes elementos 
um argumento externo agente - nulo recuperado no contexto (ninguém), um argumento interno com interpretação semântica de tema - dinheiro e um argumento interno o objeto indireto o anafórico tônico (a ele )

Em (46), o verbo ditransitivo dar, com interpretação semântica de transferência material, apresenta na sua grelha temática os seguintes argumentos: o externo nulo, (você), recuperado através da forma verbal imperativa dê; o argumento interno objeto direto - tema: condição e o argumento interno objeto indireto- pra ele, que é interpretado semanticamente como recipiente da ação.

Em (47), ocorre uma sentença em que o dativo não foi introduzido por preposição. O verbo pedir, semanticamente interpretado como de transferência material, apresenta a seguinte configuração argumental: um argumento externo nulo, recuperado no contexto - eu, o argumento interno tema - o objeto direto os refrigerantes e o argumento interno objeto indireto - ela, com a interpretação semântica de fonte, uma vez que ocorre aí uma operação inversa, em que o sujeito é o recipiente da ação

Retomando o gráfico de número 16, com dados do PEUL, realizado com habitantes do Rio de Janeiro vê-se o aumento da preposição para em relação à preposição a no decorrer de duas décadas, em verbos de transferência material (dar). Observa-se nesse gráfico um aumento em torno de quase $50 \%$ de uso da preposição para, enquanto houve um decréscimo em maior proporção das outras alternativas de uso como a preposição a e ausência de preposição.

Esse aumento da realização da preposição para em substituição à preposição a, dia-a-dia, não parece um fato isolado, pois acontece em termos de Brasil em maior ou menor proporção, conforme se observa em estudos realizados sobre o tema. 


\subsubsection{Dativos realizados com pronomes tônicos anafóricos com verbos de transferência verbal}

A Tabela 13 e os Gráficos 20, 21 e 22 exibem as ocorrências relativas aos complementos dativos representados por anafóricos tônicos preposicionados com verbos de transferência material, levando-se em conta a preposição usada e o tipo de sentenças em que tais anafóricos ocorreram.

Tabela 13 - Dativos realizados com pronomes tônicos anafóricos com verbos de transferência verbal com a preposição para e a preposição a, por tipo de oração

\begin{tabular}{|l|r|r|}
\hline \multicolumn{1}{|c|}{ Tipo de sentença } & Com para & Com aA \\
\hline Sentença Raiz & 2 & 1 \\
\hline Subordinada & 9 & 9 \\
\hline Segunda Coordenada & 3 & 0 \\
\hline Principal & 24 & 5 \\
\hline Primeira Coordenada & 2 & 0 \\
\hline & Total & $\mathbf{4 0}$ \\
\hline
\end{tabular}

Fonte: Inquéritos do Porcufort, 1993-1994.

Gráfico 20 - Ocorrências de dativos representados por pronomes anafóricos, com verbos de transferência verbal, realizados com a preposição para e preposição $a$, por tipo de oração

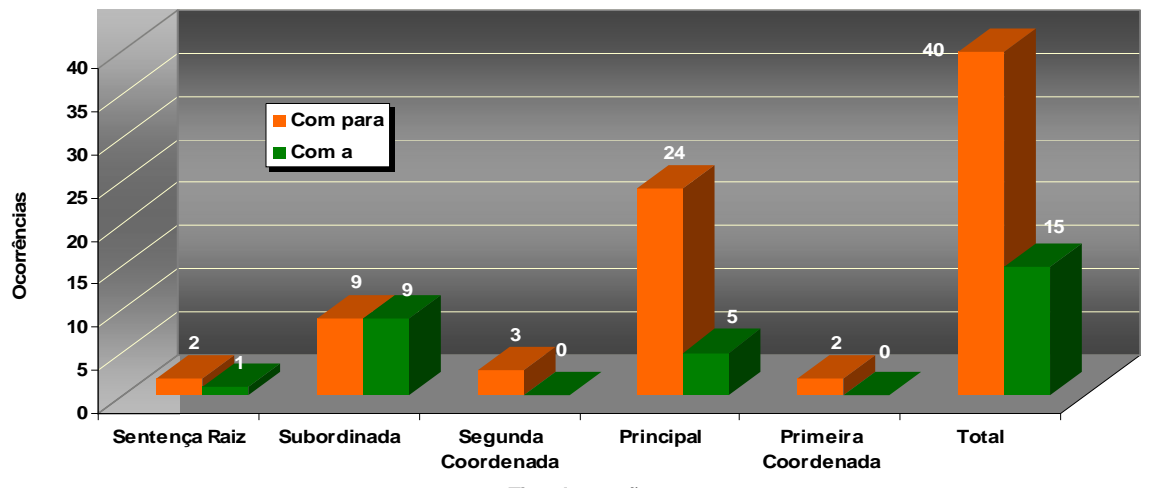

Tipo de oração

Fonte: Tabela 13 
Gráfico 21 - Ocorrências de dativos realizados com pronomes anafóricos, com verbos de transferência verbal, por tipo de preposição,segundo tipo de oração,

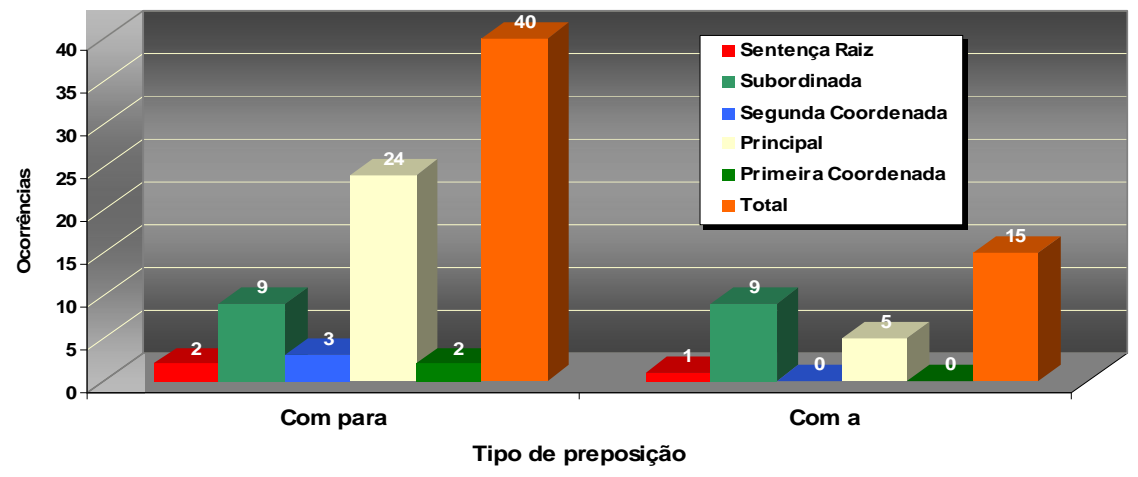

Fonte: Tabela 13

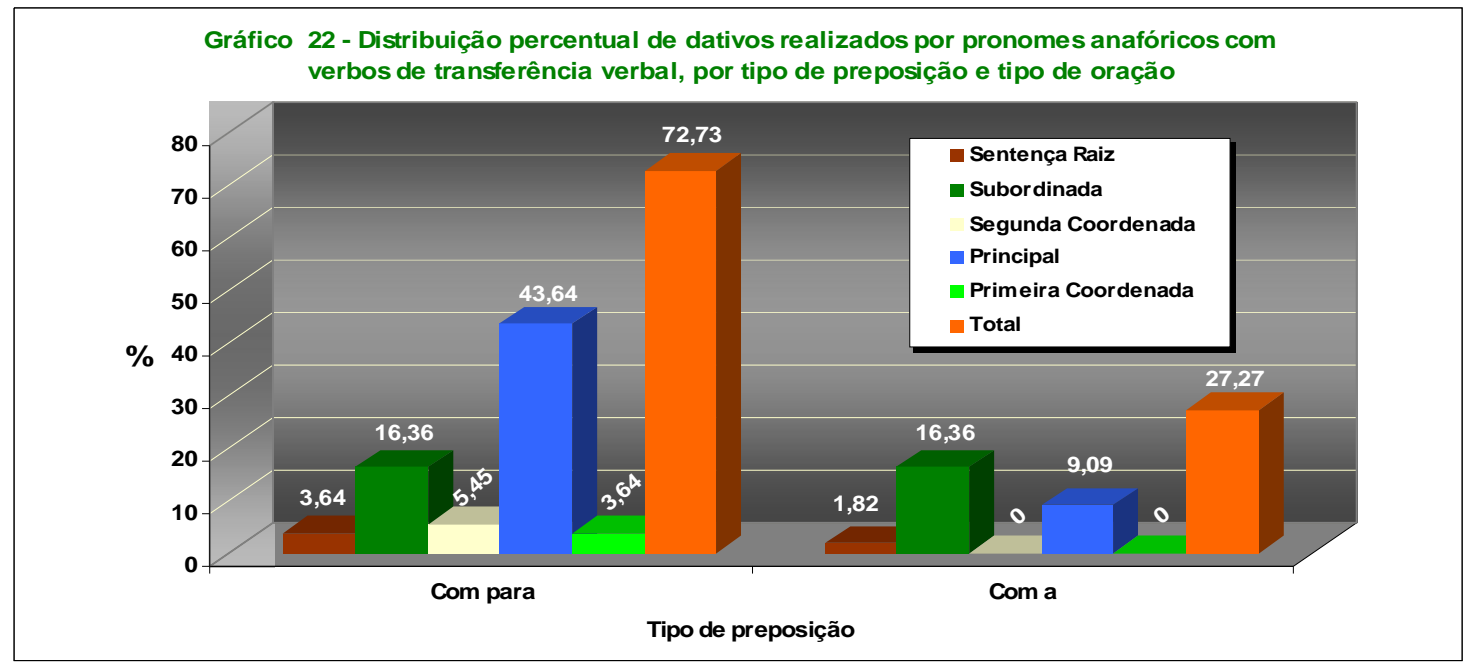

Fonte:Tabela 13

Nas realizações com anafóricos tônicos em verbos com conotação semântica de transferência verbal, observa-se que a preposição para teve 72,73 de ocorrência (40 em 55) contra 27,27\% (15 em 55) da preposição a. Isso só confirma a preferência do falante do PB por essa preposição especialmente na fala. Não houve ocorrência de anafóricos introduzidos sem preposição.

Em relação ao tipo de oração em que se deram as ocorrências, computandose as realizações com a preposição para e a preposição a constata-se que a maior incidência de realização desses anafóricos recaiu sobre as orações principais com $52,72 \%$ (29 em 55); em seguida aparecem as subordinadas, com 32,72\% (18 em 
55), As sentenças raiz e as segundas coordenadas apresentaram o mesmo número de ocorrências, com 5,45\% (3 em 55). As primeiras coordenadas tiveram o menor número de ocorrências, com 3,60\% (2/55) de realizações.

No que tange ao uso da preposição, constata-se que a preposição para, no cômputo geral, apresentou maior ocorrência: $72,73 \%$ das realizações (40 em 55), enquanto a preposição a apresentou $27,27 \%$ das ocorrência (15 em 55). Não houve realização de anafóricos tônicos com verbos de transferência material, sem uso de preposição.

Observa-se que as orações principais evidenciam maior realização da preposição para, ao passo que as subordinadas tiveram o mesmo número de realizações de para e de $a$.

Observe as sentenças abaixo:

(48) Olha eu posso porque eu/ to lá no PA::ULO...mas..já to saindo eu digo pra ele que eu.../to arranjei outro emPREg (Inq.02)

Em (48), o verbo ditransitivo dizer, com interpretação semântica de transferência verbal, apresenta a seguinte estrutura argumental: um argumento externo agente - sujeito eu, um argumento interno objeto direto - tema representado pelo CP: que eu.../ to arranjei outro emprego; um argumento interno objeto indireto, com a conotação semântica de recipiente, representado pelo pronome anafórico ele - antecedido da preposição para.

(49) Inf. 1 quê!... qual é a diferença que existe... eles num têm... ninGUÉM disse a eles que ele é gente nin \{guém disse isso (Inq 39)

Observa-se que, em (49), ocorre o verbo ditransitivo dizer com interpretação semântica de transferência verbal, em cuja grelha temática encontram-se o argumento externo agente ninguém, que transfere uma informação ou conhecimento (tema), representado pelo CP: que ele é gente ao argumento interno objeto indireto, 
com interpretação semântica de recipiente ou meta, representado lexicalmente pelo pronome forte ele, precedido pela preposição $a$.

Vejamos outros exemplos de objetos indiretos realizados com pronomes tônicos anafóricos:

(50) Inf. 1 - são muitos operários... então ninguém fala pra Eles que eles têm uma dignidade se a gente vai falar pra eles... da digniDAde de...(Inq.39)

(51) Inf. 1 orientação:.... da da turma... e eles gostavam... agora eu sempre dizendo pra eles com muita honestidade que EU não era professora daquela matéria ((ruído)

Nos anafóricos tônicos preposicionados com verbos de transferência verbal, ocorre uma maior incidência de realização da preposição para. O mesmo falante alterna as duas formas, conforme se observa em (49) e (50).

O gráfico 20 não apresenta nenhum caso de complemento com omissão da preposição.

\subsubsection{Uso do Ihe em relação às pessoas do discurso}

Observa-se, na Tabela 14 e nos Gráficos 23 e 24, a ocorrência do clítico Ihe em relação às pessoas do discurso, bem como sua distribuição percentual, em verbos com interpretação semântica de transferência material e de transferência verbal

Tabela 14 - Ocorrências do uso do clítico Ihe em relação às pessoas do discurso, com verbos de transferência material e verbal

\begin{tabular}{|l|r|r|r|r|r|r|}
\hline \multicolumn{1}{|c|}{ Tipo de verbo } & \multicolumn{2}{|c|}{ Segunda Pessoa } & \multicolumn{2}{c|}{ Terceira Pessoa } & \multicolumn{2}{c|}{ Total } \\
\hline & \multicolumn{1}{|c|}{ Ocorrências } & \multicolumn{1}{c|}{$\%$} & Ocorrências & $\%$ & Ocorrências & $\%$ \\
\hline Verbos de transferência material & 12 & 27,9 & 3 & 6,98 & 15 & 34,88 \\
\hline Verbos de transferência verbal & 28 & 65,12 & 0 & 0 & 28 & 65,12 \\
\hline Total & $\mathbf{4 0}$ & $\mathbf{9 3 , 0 2}$ & $\mathbf{3}$ & $\mathbf{6 , 9 8}$ & $\mathbf{4 3}$ & $\mathbf{1 0 0}$ \\
\hline
\end{tabular}

Fonte: Inquéritos do Porcufort 1993-1994. 


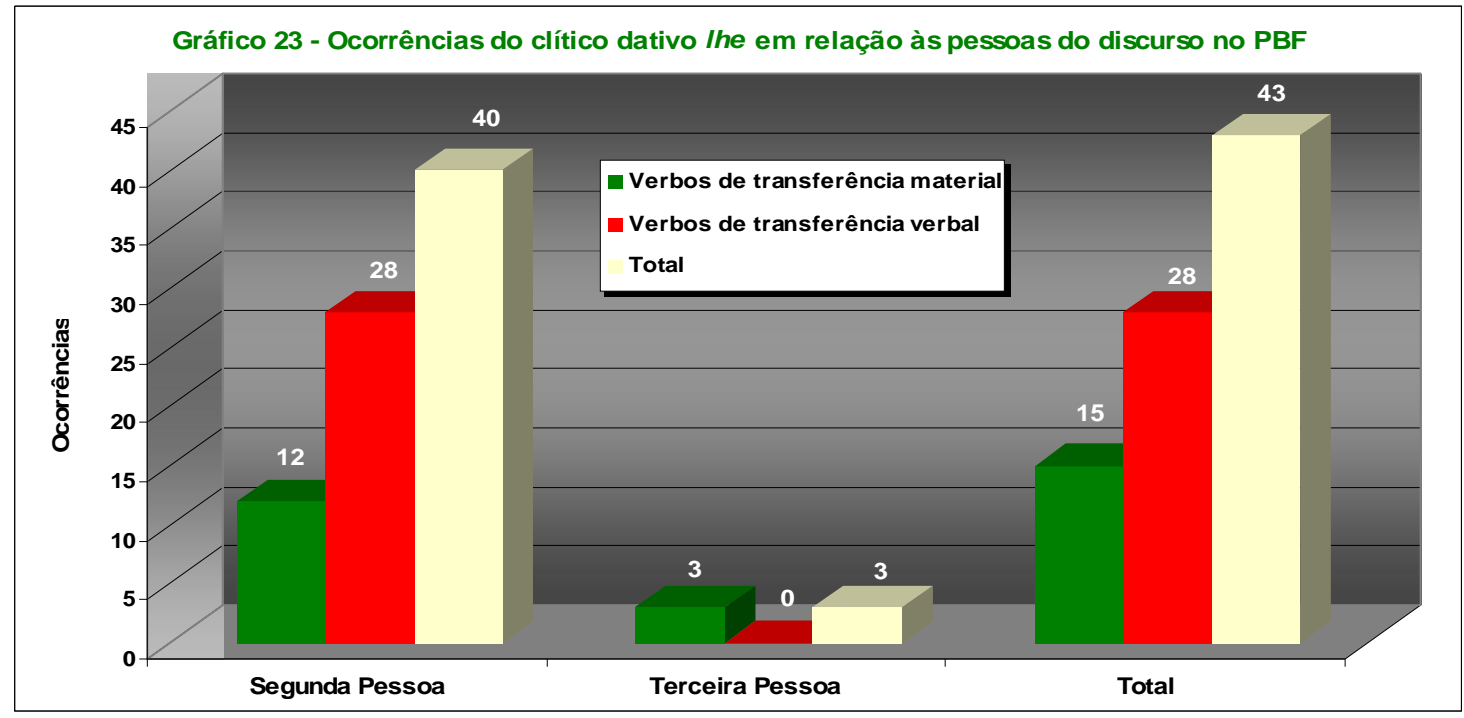

Fonte: Tabela 14

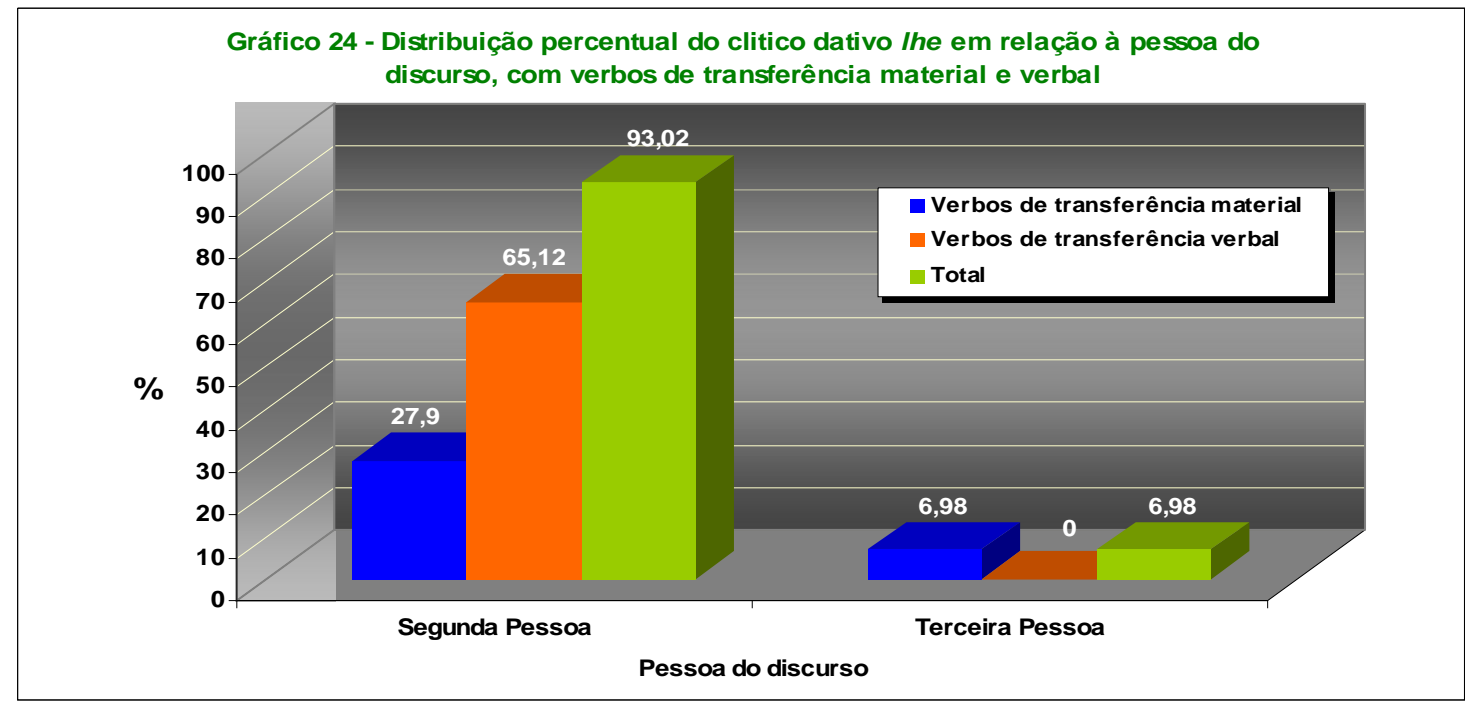

Fonte: Tabela 14

Na Tabela 14 e nos Gráficos 23 e 24, comprova-se o uso quase exclusivo do clítico the em referência à segunda pessoa, decorrência evidentemente de o pronome você ser para nós o tratamento familiar. No corpus é de Fortaleza, o uso do clítico the foi privilegiado em detrimento do te. Parece existir certa rejeição em se usar o pronome te concordando com você, optando-se pelo uso do the, numa sintaxe próxima da lusitana. Aparece o Ihe (segunda pessoa) num percentual de 
93,02\% (40 realizações em 43 ocorrências), enquanto o the, dativo de terceira pessoa aparece apenas 3 vezes, num percentual de $6,98 \%$.

A ocorrência do clítico Ihe, em referência à segunda pessoa, evidenciou-se mais com verbos de transferência verbal, o que se justifica por conta do diálogo estabelecido entre os interlocutores, no qual se usam verbos como dizer, jurar, afirmar, perguntar.

Comprova-se, através dos gráficos acima, que houve uma maior realização dos verbos de transferência verbal num percentual de $65,12 \%$, enquanto, os de transferência material apresentaram um percentual bem inferior, com $27,90 \%$ das realizações.

A não-ocorrência do the dativo de terceira pessoa sinaliza uma efetiva mudança do PB. Segundo Torres Morais e Berlinck (a ser publicado):

a baixa produtividade dos clíticos de terceira pessoa inclui-se no conjunto das reanálises que refletem a perda da expressão morfológica do dativo no $P B$. Tais tendências, porém, não parecem se manifestar no PE.

Exemplos de uso do clítico Ihe em referência à terceira pessoa:

(53) Inf.- por muito tempo... há o quê? uma carteira de estudante que:: Ihe dá o direito ((ruído)) de pagar a MEla. (Inq. 7) ( falando sobre estudantes)

(54) Inf. - é pode fica às vezes assim... Ihes dá desvio na boca né? a pessoa fica com a boca torta ... é o popular ( Inq. 01)

(55) refinamento era desejado... pelo próprio público... ou seja porque:: Ihe daria sTAtus... uhn? ((ruído)) outra característica é:: a figuração... uhn ou seja em vez i) argentino ser REalmente hospitaleiro... ( Inq. 28)

Conforme já referido, as realizações do clítico Ihe em referência à terceira pessoa são bem insignificantes. Em todo o corpus dos falantes cultos de Fortaleza, encontram-se, apenas, os três exemplos que estão transcritos acima.

Seguem-se alguns exemplos com o clítico Ihe, usado para a segunda pessoa: 
(56)_ Inf. 1 - ...pronto era sobre isso que eu queria Ihe falar né? Inf. 2 - que que ficou acertado?( Ihe usado na $2^{\text {a }}$ pessoa) (Inq.7)

(57) carro ... e NUM DESse /tava esse rapaz que eu the disse ...(interlocutor) (Inq.11)

(58) Inf. 1 é... foi... Ihe pedi ajuda... ( Ihe segunda pessoa) você me emprestou um livro ( verbo emprestar sujeito agente) (Inq. 33)

(59) só é "vó eu the prometi que eu ia passar no vestibular na primeira vez"... e eles FAzem também viu ( Inq. 33)

(60) Inf. 1- e me diga uma coisa e EU:: eu posso... eu posso:: The perguntar se você... canta alguma coisinha pra nós? (Inq. 48)

Os exemplos em (57), (59) e (60) apresentam verbos ditransitivos com conotação semântica de transferência verbal; em todos eles, o argumento externo é um sujeito de primeira pessoa. Nessas sentenças, o tema é representado por um CP (oração subordinada) e o argumento interno dativo se refere à segunda pessoa. $\mathrm{O}$ exemplo em (58) é o único em que ocorre um verbo de transferência material: pedir. 


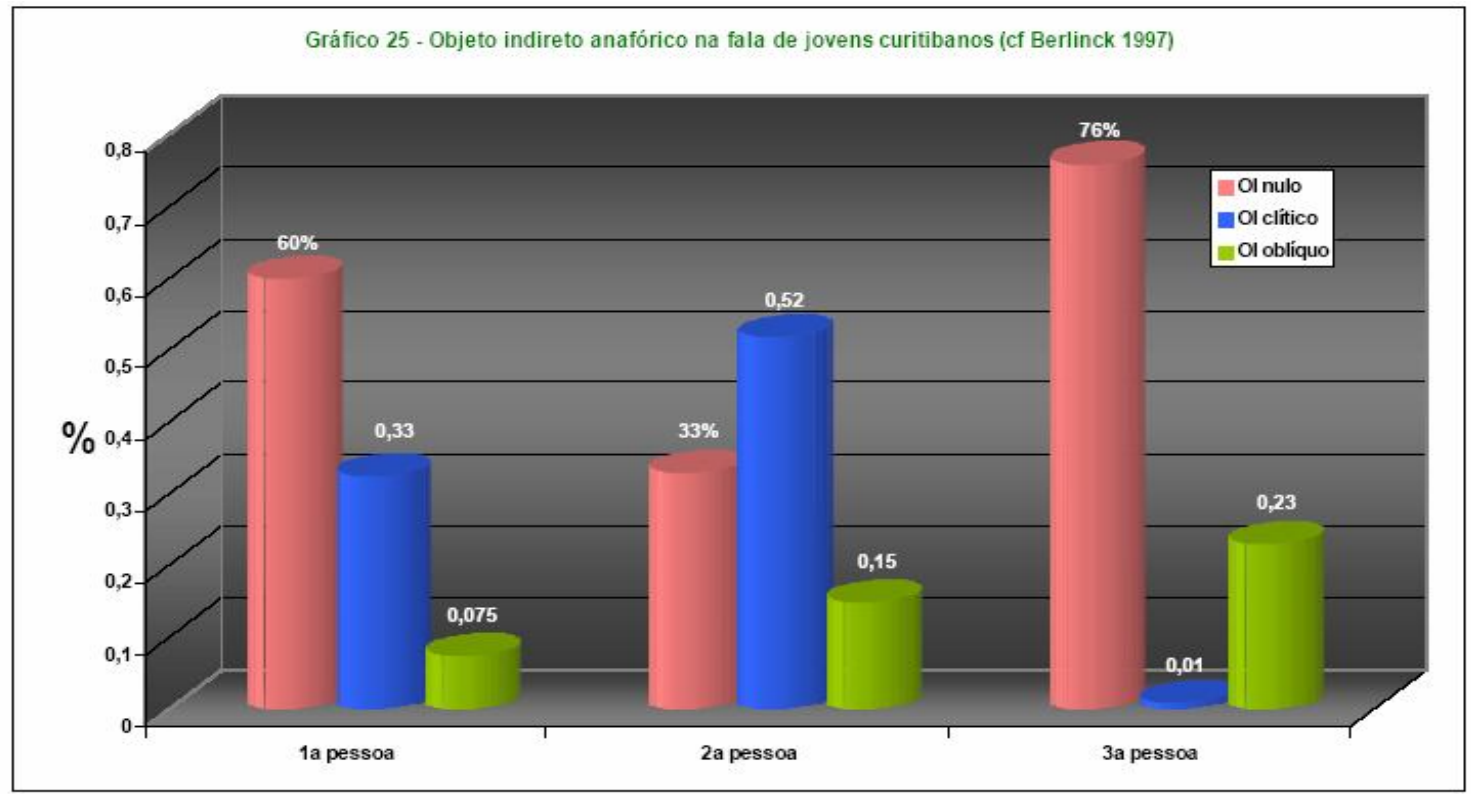

Fonte: Torres Morais \& Berlinck (2006)

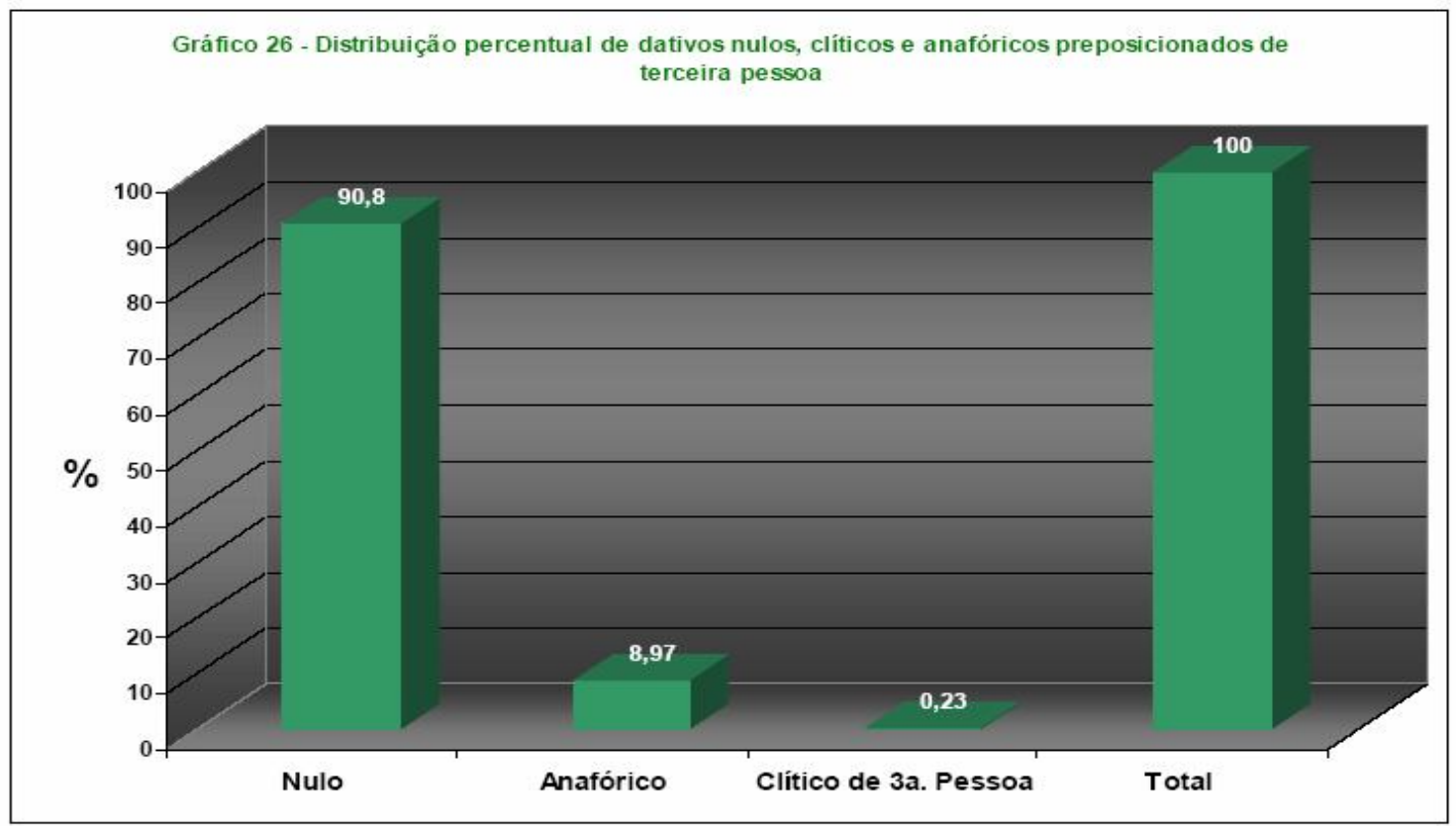

Fonte: Tabela 5 (sem inclusão dos sintagmas nominais e os clíticos de segunda pessoa)

O Gráfico 25 apresenta os resultados de estudos da fala de jovens curitibanos, confirmando que o desaparecimento do clítico de terceira pessoa e a grande incidência dos dativos nulos não são fenômenos isolados no PB. Eles ocorrem em todo o Brasil, independentemente de quaisquer circunstâncias. O 
percentual de nulo neste gráfico, em substituição ao clítico lhe foi quase igual ao percentual observado em Fortaleza, onde se verificou 75,64 de nulos.

O Gráfico 26 apresenta dados parciais extraídos da Tabela 5, incluindo apenas dativos nulos, clíticos, e anafóricos tônicos preposicionados referentes à terceira pessoa.

Comparando-se o Gráfico 25 (fala dos jovens curitibanos) com o gráfico 26 (realizações do PBF), observa-se, em relação às estratégias de substituição dos clíticos de terceira pessoa, que houve mais ocorrências de dativos nulos no PBF que na fala dos jovens curitibanos; em contrapartida, o pronome anafórico preposicionado foi mais realizado pelos jovens curitibanos do que pelos falantes cultos de Fortaleza. Em relação aos clíticos, a ocorrência nos dois grupos foi insignificante: Os gráficos demonstram que, tanto os jovens curitibanos, como os falantes cultos de Fortaleza, eliminaram, de suas realizações de fala, o clítico dativo em relação à terceira pessoa.

Para Torres Morais e Berlinck (2002, p. 10), o desaparecimento dos clíticos dativos de terceira pessoa e a substituição deles pelas forma tônicas ele(s), ela(s), sem o redobro, antecedidas pelas preposições a/para é um fato marcante que expressa claramente a diferença entre o PB e o PE.

Vale esclarecer que a grande ocorrência de nulos no PBF, talvez seja explicada por termos considerado, como já ressaltado, todos os nulos que poderiam ser argumento de um verbo ditransitivo, mesmo aqueles que não puderam ser recuperados no contexto do discurso ou da sentença; outrossim, a discrepância que ocorre entre a Tabela 5 e a Tabela 26 no que se refere ao número de realizações dos nulos e dos clíticos, decorre de terem sido considerados na Tabela 5 todos os dativos, inclusive os sintagmas nominais, que não estavam substituindo clíticos. A diminuição da porcentagem de clíticos ocorreu por conta de terem sido retirados da tabela 26 os clíticos referentes à segunda pessoa. Tais rearranjos tiveram o propósito de mostrar uma situação mais real das estratégias de substituição dos clíticos no PBF. 


\subsubsection{Colocação do c lítico dativo lhe em relação aos verbos no PBF}

A Tabela 15 e o Gráfico 27 demonstram a colocação do clítico em relação ao verbo no PBF; o Gráfico 28 evidencia diferenças na colocação do clítico entre o PBF e o PE, na modalidade oral.

Tabela 15 - Ocorrências da colocação do clítico dativo lhe em relação ao verbo no PBF

\begin{tabular}{|c|c|c|c|c|c|}
\hline \multirow[b]{2}{*}{ Tipo de colocação } & \multirow[b]{2}{*}{ Verbo } & \multicolumn{2}{|c|}{ Ocorrências } & \multirow[b]{2}{*}{ Total } & \multirow[b]{2}{*}{$\%$} \\
\hline & & $\begin{array}{c}\text { Transferência } \\
\text { material }\end{array}$ & $\begin{array}{c}\text { Transferência } \\
\text { verbal }\end{array}$ & & \\
\hline \multirow{3}{*}{ Próclise } & ao verbo finito & 12 & 20 & 32 & $74,4 \%$ \\
\hline & ao verbo principal & 03 & 08 & 11 & $25,6 \%$ \\
\hline & ao verbo auxiliar & 0 & 0 & 0 & $0 \%$ \\
\hline \multirow{3}{*}{ Ênclise } & ao verbo finito & 0 & 0 & 0 & $0 \%$ \\
\hline & ao verbo principal & 0 & 0 & 0 & $0 \%$ \\
\hline & ao verbo auxiliar & 0 & 0 & 0 & $0 \%$ \\
\hline Total & & 15 & 28 & 43 & $100,00 \%$ \\
\hline
\end{tabular}

Fonte: Inquéritos do Porcufort, 1993-1994.

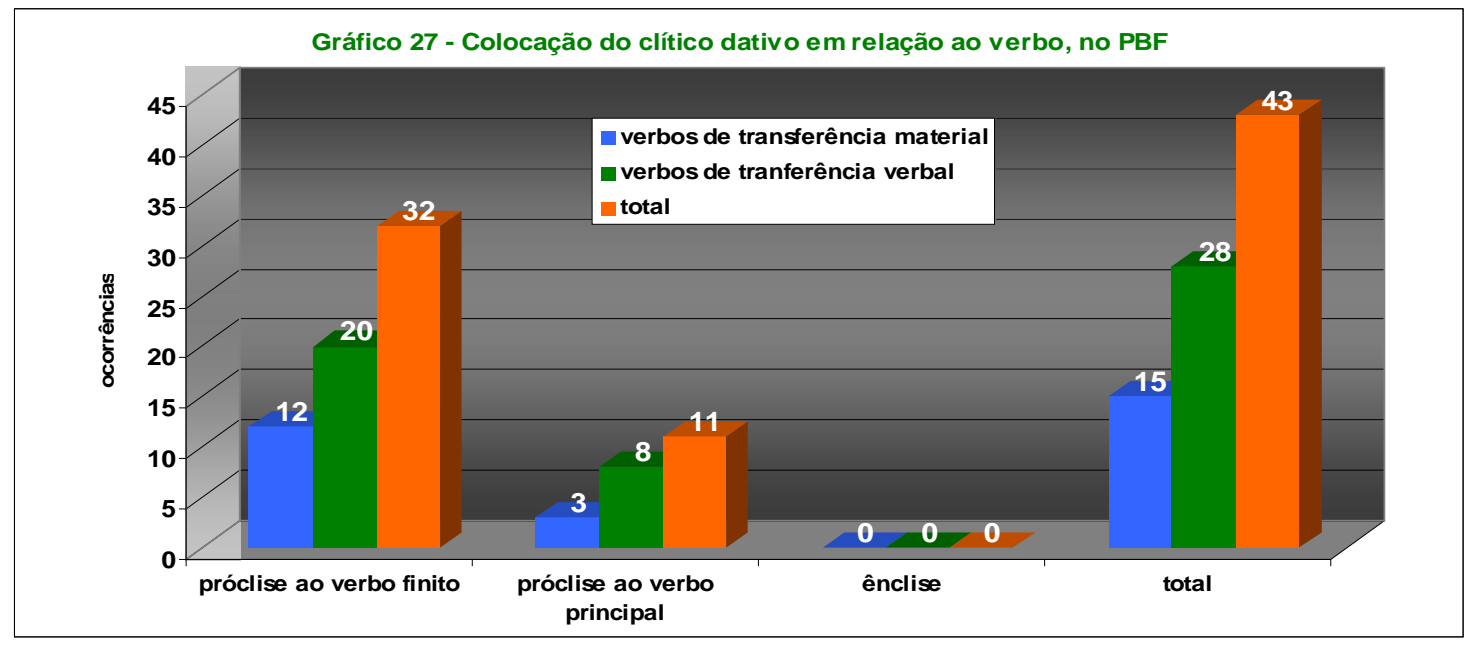

Fonte: Tabela 15

O Gráfico 27 confirma uma característica do $\mathrm{PB}$, que é a prioridade da próclise em qualquer situação da fala. Vimos que, mesmo nas elocuções mais formais, é essa a colocação que prevalece.

Percebe-se, em todos os exemplos do corpus analisado, a colocação do clítico antes do verbo, tanto nas formas finitas como nas formas infinitivas, diferentemente do que ocorre no PE e do que preconizam as gramáticas normativas 
do PB. Os exemplos em (61), (62), (63) e (64) demonstram o uso da próclise no PBF:

(61) Inf. 1- e me diga uma coisa e EU:: eu posso... eu posso:: The perguntar se você... canta alguma coisinha pra nós? (Inq. 48)

(62) só é "vó eu the prometi que eu ia passar no vestibular na primeira vez"... e eles FAzem também viu ( Inq. 33)

(63) o diploma Ihe dá o pergaminho... (Inq 5)

(64) carro... e num desse tava esse rapaz que eu the disse (Inq 11)

Conforme Galves (2001, p.38), a ênclise no PE é derivada de um movimento do verbo para uma categoria mais alta, no caso COMP. (sobre COMP ver Raposo, 1993). Considerando que o clítico deve ficar no mesmo núcleo do verbo, que é seu atribuidor de caso e que, segundo proposta de Chomsky toda relação casual envolve um núcleo funcional de concordância, entende-se por que o PB, com a sua concordância fraca inviabiliza a ênclise, uma vez que tal concordância não permite a chegada do verbo nem até a AGR, (concordância) muito menos a COMP que é uma categoria superior. Assim sendo o clítico também não pode realizar tal movimento. $O$ português europeu, ao contrário, como língua de concordância forte, realiza esses movimentos sem qualquer problema. Explica-se, portanto, porque a ênclise é encontrada no PE com tanta freqüência, sendo esta a sua colocação padrão.

Mateus et al, (2003, p. 849-851) falando a respeito da ênclise como padrão básico não marcado dos clíticos no $\mathrm{PE}$, justificam tal hipótese com dados da aquisiçã: as primeiras produções com pronomes clíticos das crianças portuguesa exibem generalizadamente o padrão enclítico e as gerações mais jovens usam a ênclise, em contextos em que a variedade padrão exigiria a próclise.

Parece que o falante do PB sente-se pouco à vontade para usar a ênclise, pois tal colocação encerra um quê de pedantismo, que não combina com a descontração da oralidade, sem contar que já há alguns escritores que usam tal 
recurso mesmo na escrita, conforme já demonstramos através de Bandeira e Drummond no capítulo 1.

Tais comprovações coincidem com as afirmações de Torres Morais e Ribeiro (2005, p.25):

Estudos lingüísticos atuais referentes à colocação dos clíticos na gramática vernacular, incluindo aí o falante letrado, e realizado em diferentes corpora, revelam que a próclise tornou-se o padrão básico nos domínios finitos e não finitos, quer se trate de orações independentes ou coordenadas, orações subordinadas e imperativas. A próclise generalizada ao verbo principal manifesta-se também nos casos em que a ordem cl-V resulta em pronome na posição inicial absoluta.

A despeito dessas comprovações, alguns gramáticos tradicionais, por exemplo, Cunha e Cintra (2001, p.309) afirmam que: "sendo o pronome átono objeto direto ou indireto do verbo, a sua posição lógica, normal é a ênclise." Embora Cunha e Cintra, nesse parecer, demonstrem o quanto suas normas afinam-se com as lusitanas, fazem uma concessão às preferências dos brasileiros, pois colocam em sua gramática alguns casos considerados como realizações próprias do BP, entre eles o uso de sentenças iniciadas por pronomes clíticos, em especial o clítico me

Já Bechara (2003, p.591), após relacionar todas as regras de colocação pronominal baseadas, em sua maioria, na sintaxe lusitana, faz a seguinte ressalva:

\footnotetext{
Nos princípios anteriormente comentados vimos certas tendências brasileiras que nem sempre a Gramática agasalha como dignas de imitação, presa que está a um critério de autoridade que a lingüística moderna pede seja revisto.
}

De acordo com Nunes (1996, p. 214 e 220), as diferenças de colocação entre o PE e o PB ocorrem por conta da direção da cliticização. A direção da esquerda para a direita, um traço inovador do PB, permite que os clíticos apareçam em início de sentença, com exceção dos clíticos acusativos de terceira pessoa, por não possuírem material fonológico que os preceda.

O espanhol apresenta uma colocação diferente dos clíticos, em alguns aspectos, tanto do PE como do PB/PBF. Assim, nas formas verbais finitas sempre se usa a 
próclise e com gerúndio, infinitivo e imperativo, a ênclise é a colocação obrigatória. Vejamos como se coloca a respeito do assunto Soriano (1999, p.1260-1261):

\begin{abstract}
La posición superficial de los clíticos no es siempre la misma, sino que pueden variar dependiendo da las propiedades de la flexión del verbo al que se adjuntan. Así, en español, cuando se trata de verbos conjugados, el pronombre aparece delante (proclisis), mientras que con infinitivos, gerundios e imperativos afirmativos se obtiene la posición posverbal (énclisis). Los participios no admiten nunca la adjunción de un clítico.
\end{abstract}

(65) Lo \{admiro/admiré/admiraré/admiraba\} mucho. (Soriano, 1999, p.1261, aqui renumerado)

(66) No es bueno admirarlo tanto. (Soriano, 1999, p.261, aqui renumerado)

Portanto, em espanhol as sentenças (65) e (66), se fossem construídas com os pronomes enclíticos e proclíticos, respectivamente, seriam agramaticais, ou seja, não seriam consideradas como sentenças pertencentes a essa língua. Evidentemente, um falante nativo do espanhol nunca realizaria tal construção, mas um aprendiz desse idioma poderia formulá-la, especialmente, se sua língua-mãe usasse um paradigma diferente em relação à colocação dos clíticos.

Vimos, até agora que todas as observações e estudos referidos a respeito do objeto indireto em suas várias formas de manifestação sinalizam para inovações que estão ocorrendo na fala dos usuários do PBF. Dentre elas, algumas já vêm ocorrendo há bastante tempo, mas continuam disputando espaço com outras formas. Outras já adquiriram, por assim dizer, "carta de brasilidade", como diz Tarallo. É o caso da colocação pronominal proclítica e a não-realização do clítico Ihe, em referência à terceira pessoa. 


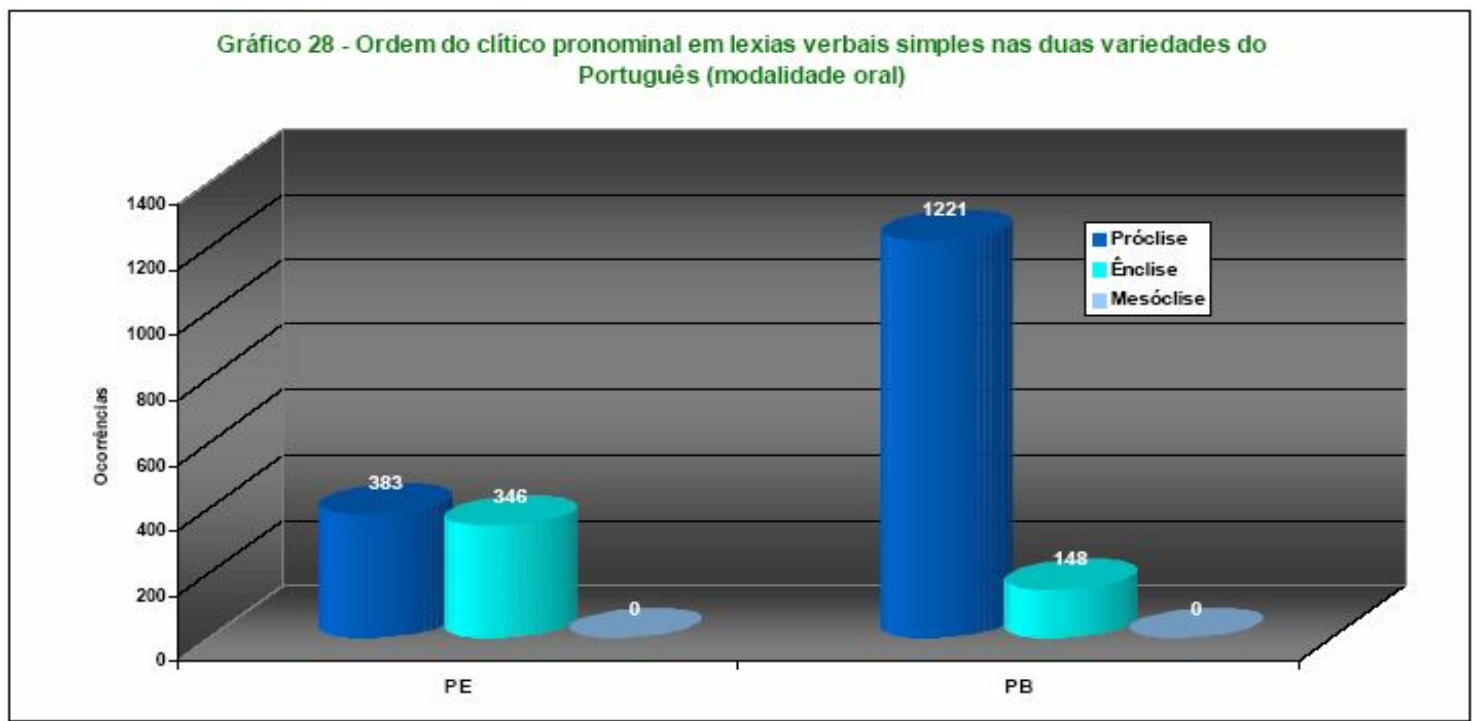

Fonte: (Vieira, 2004)

O Gráfico 28 apresenta a quantificação das ocorrências da colocação pronominal em formas finitas no PE e no PB na modalidade oral. Percebe-se no PB a próclise como uma realização bem superior à ênclise. No PE já existe certo equilíbrio entre essas duas colocações. Vale esclarecer que o uso da próclise no PE sempre ocorre mediante a presença de elementos atratores.

Quanto à mesóclise apesar de a maioria dos gramáticos do PB fazer constar tal colocação em suas gramáticas, não houve ocorrência dessa colocação, que segundo Mateus et al (2003) é vestígio de uma gramática muito antiga.

Viera (2004, p. 189) apresenta um gráfico sobre a colocação pronominal em textos escritos do PE e do PB, em que se verifica uma similaridade expressiva, havendo diferenças de 2 a 3 pontos percentuais para mais ou para menos entre o PE e o PB no que tange à próclise e à ênclise. Tal fato confirma a hipótese de Galves de que as duas variedades apresentam competências gramaticais distintas. Essas diferenças interferem nas realizações orais, ocorrendo flagrante contraste entre PE e PB; nas realizações escritas, aflora a competência lingüística dos falantes do PB, competência essa adquirida via escolarização, fazendo com que as duas variedades se aproximem bastante. 


\subsection{Realizações sintáticas do PBF que merecem destaque}

Este item trata de algumas ocorrências verificadas no PBF dignas de destaque, mas que não oferecem muitas possibilidades de serem demonstradas através de gráficos e tabelas.

\subsubsection{O pronome ele como acusativo no PBF}

Todos os estudiosos do PB se preocupam ou se preocuparam com o uso do pronome ele em função acusativa, seja para explicar a sua ocorrência, seja para ressaltar a inadequação de seu uso.

Em relação ao uso da forma tônica ele como complemento de verbo transitivo direto, Neves (2000, p.457) afirma que a gramática normativa só admite o uso dessa forma como complemento, se preposicionada. Ressalta, no entanto, que especialmente na linguagem falada, embora também na escrita, ocorrem sentenças como (61) e (62) transcritas de Neves (2000, p.457), aqui renumeradas:

(67) Benê levou ele. Levou quase à força.

(68) Quando Ludmila chegou, encontrou ele morto no banheiro.

Para Cyrino (1999, p. 605), o fato de as formas pronominais acusativas o(s), $\mathrm{a}(\mathrm{s})$ e suas variações parecerem esnobes faz com que as pessoas busquem alternativas de substituição dessas formas, encontrando-se entre essas alternativas o uso do pronome ele em função acusativa.

Segundo Nunes (1993, p.207), outro fator que propicia o uso do pronome ele na função acusativo é o não-uso do clítico acusativo de terceira pessoa motivado por questões da colocação pronominal. No PE, a colocação do pronome se faz da direita para a esquerda (privilegiando a ênclise). No PB, a colocação do pronome se dá da esquerda para a direita, prevalecendo a próclise. Tal fato torna inviável o uso dos oblíquos acusativos de terceira pessoa no PB, já que a sua pobreza fonológica 
(falta de um consoante de apoio) faz com que se dê preferência ao seu apagamento ou o uso do ele(s), ela(s) em substituição a tais clíticos.

A respeito do assunto, Câmara Júnior (2004, p.96) faz referência também à colocação pronominal, enfatizando os problemas fonológicos que adviriam da colocação proclítica dos oblíquos o(s) e a(s), por conta de tais partículas serem sílabas vocálicas sem consoante pré-vocálica, afirmando que "[...]. há, pois uma força de natureza expressiva contra o emprego do pronome oblíquo o e suas variantes do feminino e do plural."

Sobre o uso do ele em função acusativa, Câmara Júnior (2004, p.96) afirma:

É, todavia, um traço geral típico do português oral de todos os níveis sociais no Brasil; só o evitamos em certas situações, nas quais aquele que fala sente toda sua responsabilidade de homem instruído e, mesmo assim, ele não chega a eliminá-lo de todo.

Câmara Júnior (2004, p.96) enfatiza ainda que o uso de ele como acusativo não diz respeito ao caso-sujeito na função acusativa, mas ao emprego do ele como uma forma sintática invariável, como os nomes e os demonstrativos, podendo, portanto, exercer as mesmas funções sintáticas que os nomes e os demonstrativos.

A dissociação dos casos fez com que o ele passasse a exercer todas as funções gramaticais, podendo ocorrer como argumento externo, como argumento interno objeto direto e objeto indireto, como oblíquo e como predicativo.

Duarte (1989, p.19), ao analisar os gráficos de sua pesquisa com falantes do PB da periferia do Rio de Janeiro, demonstra que os jovens não usam os clíticos e que os adultos analfabetos também não o fazem. Tais formas, segundo a autora, vão aparecer na fala das pessoas, à proporção que se eleva o seu nível de escolaridade. Refere-se também às estratégias de substituição de tais clíticos, sendo uma delas o uso da forma nominativa ele ao invés do acusativo.

Não resta dúvida de que tal emprego é uma tentativa de fuga aos clíticos acusativos, no entanto, essa ocorrência no corpus analisado foi relativamente baixa, 
apenas 14 ocorrências, com certeza pelo estigma que sofrem essas formas, nas realizações de falantes com nível superior de escolaridade.

No âmago da questão está o fato de a terceira pessoa ser a não-pessoa (Benveniste, 1976, p.283) possibilitando flexibilidade no exercício de várias funções. Estamos, na verdade, falando do PB, pois no PE uma sentença com ele na função de objeto direto é considerada agramatical.

Apresentamos, abaixo, alguns exemplos do PBF com o uso do pronome ele como objeto direto

(69) a) Inf. 1 - o salário as condições o Hernandes num queria trabalhar todo dia queria uma pessoa que ajudasse ele (Inq. 2).

(70) tavam fazendo e que num /tava a fim de mudar então o que vamo/ fazer?vamo/ tirar esse cara...aí vamo/vamo/ tirar exatamente ele por quê?.Porque todo mundo já sabe que.(Inq. 28).

(71) promessa são essas... num é que num acredite em São Francisco ave Maria eu acho ele assim... uma... pra mim eh:.... um grande santo são \{Francisco (Inq.33)

(72) Inf. 1 DEle... mas sei que eu admirava ele às vezes eu ia pra /li... não pra comprar nada viu? (Inq. 4)

(73) Doc. - a senhora quer olhar ele?(Inq. 13)

(74) Doc. - por que... /tão apostando mais no Rubinho... né? o pessoal lá?... a Willians /tá querendo chamar Ele ( Inq.20)

(75) exemplo econômico né?... Aí Ela diz que... na probabiliDAde exemplo... JÁ dando as probabilidades--... deix/ eu ver se coloquei aqui se eu trouxe eles... /tá /qui...( é Inq. 38) EF 


\subsubsection{O uso do pronome the como objeto direto: o "leísmo" brasileiro}

O clítico the com função acusativa é um emprego bastante usual no PB, com - PBF tal realização ocorre de forma relativamente acentuada, uma vez que nas interlocuções dos falantes de Fortaleza, tal clítico é usado ao invés de te, conforme se observa no corpus analisado. Considerando-se que o uso das formas acusativas: o, a, os, as oferecem algumas restrições já referidas no item anterior, o the surge como uma alternativa ao uso dessa formas.

Neves (2000, p.454) faz referência ao emprego de the na função de objeto direto, nos seguintes termos: "construções com o pronome the funcionando como complementos de verbos que se constroem com objeto direto não são aceitas na norma culta".

Os exemplos abaixo foram extraídos de Neves (2000, p. 454) página 454 e aqui renumeradas como (76) e (77).

(76) Nunca Ihe vi desse jeito. Que foi, afinal? (DZ).

(77) Ora, delegado... o senhor tava era perdido no mato quando eu the encontrei...(PD).

Além de Neves (2000), outros gramáticos normativos e descritivos fazem considerações sobre o uso de Ihe acusativo, geralmente numa postura prescritiva, desaconselhando-o. Apesar dessas sanções, o uso do Ihe em função acusativa é bem produtivo no $\mathrm{PB}$, especialmente em dialetos em que se evita a concordância você/te, como ocorre no PBF.

Para explicar o emprego do pronome Ihe na função acusativa, como objeto direto, Monteiro (1994, p.86) relaciona alguns motivos que podem ocasionar tais usos:

- estratégia de fuga ao emprego do clítico acusativo, em fase de extinção;

- manutenção de uma simetria morfossintática com outros pronomes (me, te, se) que funcionam também como objetos diretos; 
- ausência da preposição, o que desestabiliza a oposição entre os dois tipos de complemento verbal; e

- recurso para desfazer a ambigüidade entre as referências à segunda ou à terceira pessoa.

Moreira da Silva (1983), citado por Monteiro (1994, p.86), menciona ainda que o Ihe passou a ser empregado como acusativo em paralelo com o tratamento respeitoso o senhor, caso em que o pronome te soa inadequado.

Ao lado dessas justificativas, por sinal, todas aceitáveis, é preciso considerar também que 0 Ihe usado na segunda pessoa, como ocorre no PBF, evidentemente, é uma forma mais conhecida, não é necessário que se vá à escola para usá-lo, faz mais parte do vernáculo do PBF. ${ }^{33}$

Além disso, tal fenômeno não é exclusivo do PB, é observada, também, em Espanhol, ocorrência conhecida por "leísmo"34. Sobre o "leísmo", Llorach (2003, p. 251) afirma:

\begin{abstract}
El llamado leísmo ofrece variedades. Consiste en el empleo de le, con menor frecuencia de su plural les, como referente de la función de objeto directo. El leísmo más extendido, y con mayor aceptación en la tradición literaria, es el que establece distinción entre la alusión a persona (o ente personificado) y lo que no es persona, cuando el sustantivo eludido comporta masculino y singular. A veces, la distinción de la persona y la no persona del masculino se extiende al plural, y se emplea les para masculino plural personal y los para masculino de cosa. Otra veces, la preferencia de le y les como directo para el masculino se deriva de la distinción entre seres animado e inanimados. En fin, especialmente en Castilla la Vieja, el leísmo se refleja en las referencias a seres contables ( como niño, perro, árbol, coche, etc), en tanto que los sustantivos no contables o continuos (como vino, trigo, carbón, barro, etc) siguen siendo referidos por las formas lo, los.
\end{abstract}

Tudo indica que o "leísmo" espanhol é mais complicado do que os usos do Ihe (de segunda pessoa), no $\mathrm{PB}$,-sendo tal forma realizada, em alguns dialetos

\footnotetext{
${ }^{33}$ Referimo-nos ao lhe segunda pessoa, pois o de $3^{\text {a }}$ parece nem mais existir.

${ }^{34}$ Refere-se ao emprego do clítico le, objeto indireto, realizado com verbos transitivos diretos, como em: le vi a Juan en la playa.
} 
brasileiros, com bastante freqüência, talvez por ser de uso simples, fácil, sem contar que não é uma forma estigmatizada como o ele acusativo

Outra consideração a ser feita em relação ao PBF refere-se ao fato de que o cearense oferece algumas restrições do uso do te em concordância com o você da comunicação informal, havendo a opção pelo lhe. O uso do Ihe dativo é facilmente transferido para o lhe acusativo.

Vejamos alguns exemplos do Ihe empregado como acusativo no PBF:

(78) Inf. 1 - porque se você der uma rata minha filha é pra vida toda...é pra vida vida toda se a criatura_lhe ver*.. A vida toda to \{da vai ... (Inq. 02)

(79) Inf. 1 ...rindo)) "você saia daí porque se não eu Ihe mato" o cara "meu amigo" (Ihe=objeto direto) (Inq. 30)

(80) Inf. 1 - dizer... mas por exemplo quando o professor tem boa vontade... /tá entendendo?... eu escute bem eu Lógico que eu eu Ihe conheço num é o seu caso... quando se todo professor (Inq. 34)

(81) assim:: até meio ... chato porque... muitas vezes o ... os parentes lhe procuram muito porque sabe que você é MÉ::dico e que você é da (Inq.1)

(82) espirrando direto né?... na UNIFOR não se você num encontrar o livro tem alguém pra Ihe auxiliar... sabe? várias (Ihe usado como objeto direto) (Inq. 05)

(83) na sua pergunta ((falou sorrindo))... e que eu num /tô the censurando não porque isso... de modo geral a Sociologia ( Ihe objeto direto ) (Inq. 10)

Não importa sob que ângulo se encare a questão, quando se comparam realizações de falantes e as normas prescritivas, o que se evidencia é que a fala, de 
certa forma, "atropela" a norma, ensejando inovações que asseguram o caráter dinâmico da língua.

\subsubsection{As realizações de DOC (Double Object Constructions) no PBF}

Conforme vimos no capítulo 1, as gramáticas normativas e descritivas, tanto do PB como do PE, caracterizam o objeto indireto como um complemento introduzido por meio de uma preposição. No que tange a esse ponto, os gramáticos apresentam uma unanimidade, surgindo algumas divergências, apenas, em relação à preposição a ser usada.

A força da preposição emergiu da desestruturação dos casos latinos, pois no latim a identificação das funções das palavras era feita mediante os casos, então além da organização da sentença ser mais livre, nexos como preposições quase não eram usados. O desaparecimento desses casos ensejou a que se buscassem estratégias para sua substituição, entre essas, destacam-se uma ordem mais rígida dos constituintes no sentença e a adoção das preposições para evidenciar os casos, dos quais só restam vestígios nas formas clíticas, especialmente nas de terceira pessoa em que ocorre a oposição acusativo/dativos.

A importância da preposição se acentuou com as idéias da Gramática Gerativa de que elas são capazes de não só marcar caso (preposições funcionais), mas também de deter um valor predicativo, ou seja, marcar tematicamente os seus próprios argumentos (preposições lexicais).

Segundo Mioto, Figueiredo Silva e Vasconcelos Lopes (2005, p.131), as preposições lexicais possuem carga semântica e são predicados, pois têm capacidade de s-selecionar argumentos, ou seja, de atribuir papel $\theta$. As funcionais, ao contrário, não possuem carga semântica e não são predicados. Quando elas aparecem, a seleção do argumento é feita pelo verbo ou pelo nome, ou seja, é o verbo ou o nome que atribui o papel $\theta$. Embora as preposições funcionais não possam atribuir papel $\theta$, elas têm uma função, como o próprio nome indica, que é a 
de atribuir caso, indica, entre esses, o caso dativo aos complementos verbais. Os autores (2003, p.130-131) apresentam os exemplos de preposições e lexicais e funcionais aqui renumerados como (85) e (86) respectivamente.

(85) Meu chefe viajou para Curitiba.

(86) A conquista da lua pelo homem

Em (85), o verbo viajar não seleciona complemento, mas a palavra Curitiba possui um pape $\theta$, que é atribuído pela preposição lexical para.

Em (86), a palavra conquista seleciona o complemento, que é a palavra lua, no entanto, para que tal complemento adquira visibilidade, é necessária a presença da preposição funcional de, que, embora seja apenas marcador de caso, é fundamental para garantir a gramaticalidade da sentença

Diante de quadro em que se evidencia a importância da preposição, torna-se interessante discutir a sua ausência em construções em que sua presença seria um tanto quanto obrigatória. $\mathrm{Na}$ verdade, essa ausência ocorre em inglês nas construções de DOC, uma das faces da alternância dativa nessa língua.

O português oral culto de Fortaleza não foi o primeiro dialeto a apresentar as construções com objetos indiretos sem preposição. Scher (1996), detectou tal fenômeno em realizações de falantes da Zona da Mata Mineira, objeto de estudo em sua dissertação de mestrado As Construções com Dois Complementos no Inglês e no Português do Brasil. Portanto, tais construções, embora inovadoras, não são inéditas em termos de PB.

Segundo Scher (1996), existem três tipos de complementos verbais que na realização com a preposição a/para apresentam comportamentos diferentes: os que só admitem a preposição para, sendo tal preposição responsável pela atribuição de papel $\theta$ ao sintagma nominal, ou seja, s-seleciona tal complemento. Entre esses verbos destacam-se: buscar, cantar, comprar, conseguir, desenhar, descrever e fazer. 
Scher(1996) menciona ainda alguns verbos que, embora admitam a alternância a/para, também não admitem a omissão da preposição: deixar, descrever, endereçar, escrever, insinuar, mentir, trazer. Com tais verbos, o papel $\theta$ seria atribuído ao sintagma nominal também pela preposição, razão por que sua presença é obrigatória.

Ainda de acordo com Scher (1996), os verbos anunciar, comunicar, contar, dar, dizer, emprestar, ensinar, entregar, enviar, explicar, mandar, mostrar, oferecer e pedir admitem a alternância a/para antes dos sintagmas nominais, mas permitem a omissão da preposição. Baseando-se em Larson, Scher (1996) diz que [...] isso ocorre porque tanto o verbo como a preposição atribuem papel $\theta$ ao complemento. Tal redundância de papel $\theta$ possibilita a omissão da preposição.

Vale a pena observar que, nessas ocorrências, como na língua inglesa, o objeto indireto vem logo após o verbo e o DP tema vem depois, ou seja, o objeto indireto c-comanda assimetricamente o DP tema. Os exemplos (87), (88) e (89) foram retirados de Scher (1996) e aqui renumerados:

(87) Anunciar a decisão (para/a) os filhos. (Anunciar os filhos a decisão)

(88) Comunicar a decisão (para/a) os amigos. (Comunicar os amigos a decisão)

(89) Pedir (um favor(para/a)) o pai. (Pedir o pai um favor)

O interesse em fazer referência ao estudo de Scher (1996) reside no fato de haver, no corpus do PBF, algumas ocorrências de objetos indiretos ligados diretamente ao verbo, sem auxílio de preposição, ou seja, construções de objetos duplos.

Observem-se os exemplos abaixo retirados do PBF:

(90) Inf: e pediu [ ] o aluno pra perguntar à diretora e a diretora (Inq. 07) 
(91) Inf. 2 - ah agora eu vou te perguntar tu que é... tu que ensina literatura... que literatura vai dar [ ] esses aluno da quinta série? que tipo de literatura? (Inq.116)

(92) Doc. - aí a professora perguntou [ ] cada um né?_ "que que vai fazer?"... aí eu disse assim:: eu sabia... que ia fazer Letras né?...(Inq. 12)

(93) Inf. 1 - é justamente esse texto que eu disse que ia levar pa/ mostrar [ ] o Simões (Inq. 16)

(94) Inf. 2 quer dizer que você diz [ ] o outro a... você você::.... você tem direitos você::... tem que lutar pelo seus direitos... você tem direito ... (Inq. 33)

$\mathrm{Na}$ sentença em (90), aparece o verbo ditransitivo pedir, semanticamente considerado de transferência material, o argumento interno (objeto indireto) - 0 aluno apresenta o papel temático fonte. Tal argumento interno ocorre também sem auxílio de preposição e não resta dúvida de que a expressão em destaque é realmente argumento do verbo. Na sentença, ocorre uma operação reversa, em que o complemento verbal objeto indireto é a fonte e não o recipiente da ação verbal.

Em (91) o verbo ditransitivo dar apresenta o interpretação semântica de transferência material. A grelha argumental do verbo é assim constituída: argumento externo (agente) $t u, o$ argumento interno objeto direto- que literatura e argumento interno objeto indireto - esses alunos de quinta série, que apresenta a interpretação semântica de recipiente e é introduzido sem auxílio de preposição.

Em (92), temos o verbo ditransitivo perguntar com papel semântico de transferência verbal, em que há um argumento externo +animado/humano - a professora, um argumento interno objeto indireto com papel temático de recipiente cada um, que se realiza sem a presença da preposição a e um argumento interno tema representado por um CP - que é que vai fazer. 
Em (93), o verbo ditransitivo de movimento mostrar apresenta a seguinte configuração sintática: argumento interno eu (nulo recuperado no contexto sintático), o argumento interno tema ( objeto direto nulo recuperado também no contexto sintático- o texto) e o argumento interno objeto indireto o Simões, com interpretação semântica de recipiente. Tal argumento foi ligado ao verbo sem auxílio de preposição, numa construção de objeto duplo.

No exemplo em (94), o verbo ditransitivo dizer, com conotação semântica de transferência verbal, apresenta a seguinte grelha temática: um argumento externo que realiza a ação - você e dois argumentos internos: o argumento interno objeto indireto, com interpretação semântica de recipiente- o outro, que se liga ao verbo sem auxílio de preposição e o tema representado pelo CP- você tem direto...

Observando as cinco sentenças acima pertencentes ao corpus analisado, constatamos que os verbos, cujas preposições foram omitidas, já constam da relação dos que admitem tal omissão, de acordo com Scher: dar, dizer, ensinar, mostrar e pedir. Aparecem, no corpus, outros verbos com realização de objeto indireto sem preposição, entre eles: pagar e perguntar, que são da mesma natureza que dar e dizer, inclusive com o mesmo papel semântico (cf. Berlinck, 2001) e grelha temática, portanto, os motivos da perda da preposição podem ser os mesmos.

Com base nos estudos de Torres Morais (2006), é possível afirmar que os complementos verbais objetos indiretos introduzidos sem auxílio de preposição encontrados no dialeto da Zona da Mata Mineira (PBM) e no dialeto dos falantes cultos de Fortaleza (PBF) colocam tais dialetos do PB no contexto de alternância dativa. Tal fenômeno, considerado anteriormente, como uma realização somente do inglês, deixou de ser considerados uma exclusividade dessa língua, mapós estudos realizados com as línguas bantas. Descobriu-se, após tais estudos, que muitas línguas podem apresentar alternância dativa, inclusive o espanhol, o PE e o PB, este último através das construções com objeto duplo, ao lado do inglês. Nesse caso, o $\mathrm{PB}$, assim como o inglês, admite construções com o núcleo aplicativo, ou seja, construções em que ocorre um núcleo que licencia argumentos. 
As realizações de DOC do PBF comprovam a hipótese levantada por Torres Morais (2007) de que o argumento interno objeto indireto realiza-se dialetalmente no PB através de um núcleo aplicativo baixo, nas construções de objeto duplo, aos moldes do inglês, em que um núcleo aplicativo licencia o argumento interno objeto indireto, o qual se realiza com omissão da preposição.

Neste capítulo, chegamos a conclusões bem interessantes a respeito do PBF, as quais confirmam alguns estudos já realizados anteriormente, com base em outros corpora. Comprovaram-se, entre outros, os seguintes fenômenos:

a) a extinção do clítico dativo Ihe em referência à terceira pessoa;

b) o uso do complemento nulo seguido dos anafóricos tônicos preposicionados como alternativas mais usuais de substituição de tais clíticos;

c) o emprego do clítico the em referência à segunda pessoa, ou seja, nas interlocuções;

d) o uso da preposição a na introdução do objeto indireto em concorrência com a preposição para, favorecendo a realização das construções ditransitivas preposicionadas;

e) a perda da realização da preposição a como marcador de caso dativo e, conseqüente impossibilidade de realização dos a-DPs, fato que inviabiliza a alternância dativa e, conseqüentemente, as construções aplicativas aos moldes do PE;

f) construções de objeto duplo e conseqüente inserção do PBF nos dialetos do PB que apresentam realização de núcleo aplicativo aos moldes do inglês;

g) o uso da próclise como alternativa exclusiva de colocação pronominal, tanto nas formas finitas, como nas não-finitas. 
Verificamos que o PBF apresenta também outras inovações que ocorrem no $\mathrm{PB}$, tais como o uso do pronome tônico ele como objeto direto e o emprego do clítico dativo Ihe na função acusativa. 


\section{CAPÍTULO 4 - O CRPC E AS REALIZAÇÕES DO COMPLEMENTO DATIVO}

Este capítulo, além de apresentar o Corpus de Referência do Português Contemporâneo (CRPC), tem o objetivo descrever as realizações dos falantes do $\mathrm{PE}$, identificadas nos inquéritos orais do referido Corpus, em que ocorre o complemento dativo na terceira pessoa, considerando as seguintes variáveis: complementos nulos, sintagmas preposicionados, pronomes tônicos anafóricos preposicionados e clíticos.

As variáveis já referidas são analisadas levando-se em conta os seguintes fatores: tipologia semântica do verbo, (transferência material e transferência verba), o tipo de preposição que antecede o complemento, bem como as orações em que tais complementos ocorrem. Em se tratando de clíticos, atenta-se para a pessoa a que tais clíticos se referem e para a sua colocação em relação aos verbos. Além da descrição tecemos também alguns comentários sobre alguns aspectos do PE, considerados relevantes na pesquisa.

Vale esclarecer que, em relação ao complemento nulo, foram considerados dentro dessa categoria, todos os possíveis complementos de verbos ditransitivos, mesmo daqueles verbos que aparentam uma certa intransitividade. Todos os sintagmas nominais foram codificados e considerados na pesquisa, independentemente de serem ou não estratégias de substituição dos clíticos.

Estamos trabalhando com a hipótese de Torres Morais (2006), de que o PE realiza a alternância dativa da seguinte forma: através das construções com os aDPs em que há um dativo puro introduzido pela preposição dummy a, ou seja, um marcador de Caso dativo e das construções ditransitivas preposicionadas, em que o argumento internos PP é s-selecionado por uma preposição lexical. O licenciamento do argumento a-DP ocorre através de um núcleo aplicativo, que não se realiza fonologicamente. 


\subsection{Apresentação do CRPC e justificativa de sua escolha}

O Corpus de Referência do Português Contemporâneo (CRPC) foi organizado em 1978, por iniciativa do Centro de Lingüística da Universidade de Lisboa.

É um corpus eletrônico formado por 334 milhões de palavras, composto por discursos orais e por várias modalidades de discurso escrito, indo do literário ao jurídico, passando pelo jornalístico e pelo didático, entre outros. Os discursos orais contemplam tanto as elocuções formais como as informais. O raio de ação desse corpus não se limita a Portugal, mas alcança muitos outros países de fala portuguesa como: Brasil, Angola, Cabo Verde, Guiné Bissau, Moçambique, São Tomé e Príncipe, Macau, Timor Leste e Goa.

O período de abrangência do corpus vai da segunda metade do século XIX até 2006, mas a sua maior parte é posterior a 1970, década à qual pertencem os textos estudados neste trabalho.

Os inquéritos orais, objeto desse estudo, foram realizados inteiramente em Portugal e se acham disponíveis na Internet ${ }^{35}$.

A parte do Corpus de Referência do Português Contemporâneo (CRPC) objeto do presente estudo compreende os inquéritos com registro da linguagem oral espontânea, realizados com pessoas de vários níveis de instrução, níveis esses catalogados de acordo com escala crescente de escolaridade:

0 - analfabetos;

1 - nível primário de escolarização;

2 - 1ํㅗㅇㅣ

3 - $2^{\circ}$ ciclo liceal ou equivalente;

4 - 3ํo ciclo liceal, curso médio;

${ }^{35}$ Para consultar o corpus ver www.clul.pt/sectores/corpus oral pf publicado zip (consultado em abril de 2003). 
5 - freqüência universitária; e

6 - curso superior completo.

Não há exatamente a mesma quantidade de pessoas entrevistadas em cada nível. Assim, foram entrevistadas apenas 7 pessoas analfabetas ${ }^{36}$, 30 pessoas com nível primário, 17 pessoas com o primeiro ciclo, 21 pessoas com o segundo ciclo, 27 pessoas com o ensino médio e 28 pessoas, com nível superior. Assim como o nível de instrução, a faixa etária dos entrevistados também varia, indo dos 16 aos 61 anos.

As entrevistas, num total de 140, contendo 112.053 palavras, foram realizadas no período de 1970 a 1974, em várias localidades de Portugal: Aveiro, Coimbra, Beja, Braga, Bragança, Castelo Branco, Évora, Faial, Faro, Funchal, Guarda, Leiria, Portalegre, Porto, Santarém, São Miguel, Setúbal, Viana de Castelo, Vila Real e Viseu.

Embora em alguns aspectos os corpora do português oral culto de Fortaleza e o do português europeu pareçam díspares, é perfeitamente viável a comparação entre os dois.

Uma das diferenças verificadas entre eles diz respeito à quantidade de inquéritos investigada no PE (CRPC) e no PBF (Porcufort). Tal diferença ocorre em virtude de as entrevistas do PB serem bastante longas, enquanto as do PE serem muito breves, o que se pode perceber pela quantidade de palavras dos dois corpora. Contudo, tal desproporção não causa prejuízo ao estudo, tendo em vista que a comparação entre os dois conjuntos é feita em níveis percentuais.

Por outro lado, a diferença de nível dos entrevistados também não compromete a pesquisa, uma vez que no PE o clítico Ihe (terceira pessoa) e o objeto

\footnotetext{
${ }^{36}$ A pequena quantidade de inquéritos realizados com pessoas sem nenhuma escolaridade poderia ser atribuída a um eventual baixo contingente de analfabetos em Portugal; contudo, pesquisas na Internet não corroboram essa hipótese, pois há notícia de um percentual de $20 \%$ a $30 \%$ de analfabetos, entre homens e mulheres, na faixa dos 65 anos. Esses dados foram colhidos através de artigo de Ana Rodrigues, veiculado através da Rádio Renascença , em 16-09-2004. Segundo Ana Rodrigues, há, ainda em Portugal, um percentual geral de $9 \%$ de analfabetos.
} 
indireto introduzido pela preposição a fazem parte do vernáculo do falante, portanto, todas as pessoas podem realizar tais construções, independentemente do grau de instrução. Tal fato se observa dentro do próprio corpus, pois as pessoas analfabetas realizam com certa freqüência o uso do clítico dativo de terceira pessoa, numa demonstração de que não o ignoram, bem como utilizam a preposição $a$, introduzindo o objeto indireto.

Selecionamos alguns exemplos do CRPC que corroboram a idéia que defendemos de que no PE, mesmo as pessoas analfabetas realizam os clíticos dativos de terceira pessoa com certa familiaridade, uma vez que eles fazem parte da sua competência gramatical, nos dizeres de Galves (2001).

Outra consideração a ser feita sobre os exemplos do CRPC é que ocorre no corpus o uso do clítico Ihe, referindo-se não só à terceira pessoa, mas também à segunda pessoa, embora no PE o tratamento familiar na interlocução seja o $t u, o$ uso do the nos inquéritos, referindo-se à segunda pessoa, justifica-se por haver muitas vezes um tratamento cerimonioso entre o entrevistador e o entrevistado, seja por diferença de idade, seja por falta de familiaridade entre eles.

\subsection{Complementos dativos no CRPC e construções paralelas}

As construções com dativos no CRPC seguem, geralmente, a tradição gramatical portuguesa: o dativo é introduzido pela preposição a com estatuto de marcador de caso; o clítico the em referência à terceira pessoa é usado normalmente, sem que haja a sua substituição pelos anafóricos tônicos a ele (s), a ela (s). Convém lembrar que a realização do complemento nulo como estratégia de substituição do clítico Ihe é também bastante produtiva no CRPC. 


\subsubsection{Exemplos de complementos dativos no CRPC}

Destacam-se, abaixo, sentenças do CRPC com o dativo representado por clíticos referentes à terceira pessoa, por serem esses clíticos mais condizentes com os objetivos da nossa proposta de trabalho, por sintagmas nominais introduzidos pela preposição a, por complementos nulos e por pronomes tônicos anafóricos.

\section{Clíticos dativos (terceira pessoa):}

(1) E eu disse-Ihes assim: «então como é? domingo é que eu vou ter folga, vós ides cozinhar... ( inq. 75) (falante analfabeto)

(2) [,,,]e ao depois ele dizia sempre que eu que nunca era mulher para ganhar um tostão. e eu dizia-Ihe a ele: «não tenhas medo que eu também não...( inq. 839) (falante analfabeto)

(3) Conheço mais ou menos os nomes de, de... das comidas, conheço, não é verdade, explico-Ihe... (inq.41) (falante de baixa escolaridade)

\section{Dativos representados por sintagmas nominais}

(4) x: pessoas que têm fé, a prometem ao senhor são Brás, (inquérito 1055) (falante analfabeto)

(5) D: Há uma coisa que vocês. d: há uma coisa que que vocês têm de perguntar aí ao doutor x.( inq. 236) ( falante com curso superior)

\section{Dativos representados por complementos nulos}

(6) Telefonei para cima e disse [ ]: «menina, o senhor NP não está?» (Inq. 22) (falante de baixa escolaridade)

(7) $\mathrm{x}$ : e, e ele vai recebendo de, de pessoas, voluntariamente que queiram dar [] dinheiro( inq. 111) (falante com curso superior) 


\section{Dativos representados por pronomes tônicos anafóricos ${ }^{37}$}

(8) c: eu assim chego a casa, faço o chá para ele e para mim (Inq.1383) ${ }^{38}$ (construção ditransitiva preposicionada) (baixa escolaridade)

(9) x: e essa gente bordou coisas para ela inquérito (Inq.816) (construção ditransitiva preposicionada ${ }^{39}$ ) nível superior

\subsubsection{Realizações de complementos verbais com a preposição para e outras ocorrências do CRPC}

Relacionamos, neste item, algumas ocorrências de fatos curiosos do PE em relação ao uso da preposição. Algumas dessas ocorrências verificadas no CRPC são consideradas marginais, mesmo pelas gramáticas descritivas do PE. Incluímos, dentre os exemplos considerados marginais, uma sentença do Cordial- $\operatorname{Sin}^{40}$, extraída de em Torres Morais e Berlinck (2004).

É possível que a maioria dos falantes do PE considere as sentenças abaixo como realizações não possíveis no $\mathrm{PE}$, ou seja, são sentenças agramaticais. A outra possibilidade é de que, no PE, já comece a delinear-se alguma mudança em termos dos dativos puros, que entraram em competição com as ditranstivas preposicionadas, fato já consumado no PB. Vale ressaltar que Torres Morais e Berlinck (2005, p.9), ao comentarem o exemplo do Cordial-Sin, aqui renumerado como 10 , teceram a seguinte observação:

Observe-se que o exemplo é duplamente interessante uma vez que além da preposição para, temos também o redobro do clítico sem a topicalização do argumento dativo. Ambas as possibilidades parecem não fazer parte dos usos cultos do PE atual. Essas ocorrências sugerem que a expressão do argumento dativo pode apresentar diferenças importantes no PE, segundo se analise a norma padrão e variedades com menor prestígio.

\footnotetext{
${ }^{38}$ Os anafóricos preposicionados em (9) e (10) não são realmente dativos. São PPs como conotação semântica de beneficiário; o para é uma preposição lexical. Esses são exemplos de ditransitivas preposicionadas

${ }^{38}$ As construções ditransitivas preposicionadas são a outra face das construções dativas, pois os dativos só podem ser a-DPs, ou seja, a preposição que o introduz é o $a$, marcador de caso dativo.

${ }^{40} \mathrm{O}$ Cordial -Sin é um corpus do PE com objetivo de investigar os dialetos do PE, no que se refere à sintaxe.
} 
(10) E então,(...) dizia-Ihe $o$ avô para o neto, dizia: é a coisa mais fácil que há" ( exemplo transcrito de Torres Morais e Berlinck (2005)

(11) ia dizendo para a minha mãe:"olhe isto aqui tem uma vista linda" (inq.109)

(12) vai lá buscar uma caralhota para a avó!» sem, sem nada, (Inq. 248)

(13) e fui tolhida de medo. mas quando cheguei ao meio do caminho, eu disse assim para uma senhora que ia do meu lado: " o avião já subiu?" ( Inq.894)

(14 ) a: mas quais são os tipos de artigos que tu vendes mais? X: eu? Para os espanhóis ou para os portugueses? (Inq.1093)

(15) acabam de comer e diz o pai para o filho: «rapaz, vai lavar a a boca (Inq.22)

(16) x: não quer, inclusivamente, dar um tostão para os filhos (inq.53)

Observe-se, nos exemplos acima que tanto os verbos ditransitvos de transferência verbal como os de transferência material são introduzidos pela preposição para.

\subsection{Descrição e análise das ocorrências do CRPC referentes aos complementos dativos em suas várias formas de representação}

Além da descrição das realizações verificadas no levantamento de dados e a análise do que representam esses resultados em termos dos fenômenos lingüísticos avaliados, decidimos incluir sua representação por meio de tabelas e gráficos, visando a uma maior clareza.

Desta forma, optamos pela representação gráfica dos resultados, sob várias perspectivas, como: tipologia semântica de verbos, tipo de oração em que se verificaram os eventos, tipo de preposição utilizada etc.

Assim, cada tabela referente aos dados numéricos encontrados deu origem a um ou mais gráficos para cada fenômeno. Esse procedimento foi realizado com a função de evidenciar enfoques diversos de um mesmo dado. Por vezes, optamos 
por separar, em gráficos distintos, ocorrências (valores absolutos) e percentuais relativos. No rodapé de cada gráfico está indicada a tabela da qual foi extraído.

\subsubsection{Complementos dativos em todas as suas formas de representação com verbos de transferência material e de transferência verbal}

Nas Tabelas 16 e 17 evidenciam-se todas as realizações de dativo do CRPC (representados por objetos nulos, sintagmas nominais preposicionados, anafóricos tônicos e clíticos) com verbos de transferência verbal e material, apresentando-se os níveis percentuais de ocorrências. Os gráficos 29 e 30 oferecem uma interpretação visual do número de ocorrência do dativo em suas várias realizações e o registro do seu percentual respectivamente.

Tabela 16 - Ocorrências de dativos encontrados no CRPC, com verbos de transferência material e verbal, por tipo de dativo

\begin{tabular}{|c|c|c|c|}
\hline & $\begin{array}{l}\text { Verbos de } \\
\text { transferência } \\
\text { material }\end{array}$ & $\begin{array}{c}\text { Verbos de } \\
\text { transferência } \\
\text { verbal }\end{array}$ & Total \\
\hline Nulo & 56 & 99 & 155 \\
\hline Sintagma preposicional & 57 & 39 & 96 \\
\hline Anafórico & 1 & 0 & 1 \\
\hline Clítico & 60 & 68 & 128 \\
\hline Total & 174 & 206 & 380 \\
\hline
\end{tabular}

Fonte: Inquéritos do corpus CRPC

Tabela 17 - Distribuição percentual de dativos encontrados no CRPC, com verbos de transferência material e verbal, por tipo de dativo

\begin{tabular}{|l|r|r|r|}
\hline & \multicolumn{1}{|c|}{$\begin{array}{c}\text { Verbos de } \\
\text { transferência } \\
\text { material }\end{array}$} & $\begin{array}{c}\text { Verbos de } \\
\text { transferência verbal }\end{array}$ & \multicolumn{1}{|c|}{ Total } \\
\hline Nulo & 13,17 & 28,29 & 41,46 \\
\hline Sintagma preposicional & 15,00 & 10,26 & 25,26 \\
\hline Anafórico & 0,26 & 0,00 & 0,26 \\
\hline Clítico & 15,79 & 17,89 & 33,68 \\
\hline Total & $\mathbf{4 4 , 2 2}$ & $\mathbf{5 6 , 4 4}$ & $\mathbf{1 0 0 , 6 6}$ \\
\hline
\end{tabular}

Fonte: Inquéritos do corpus CRPC 


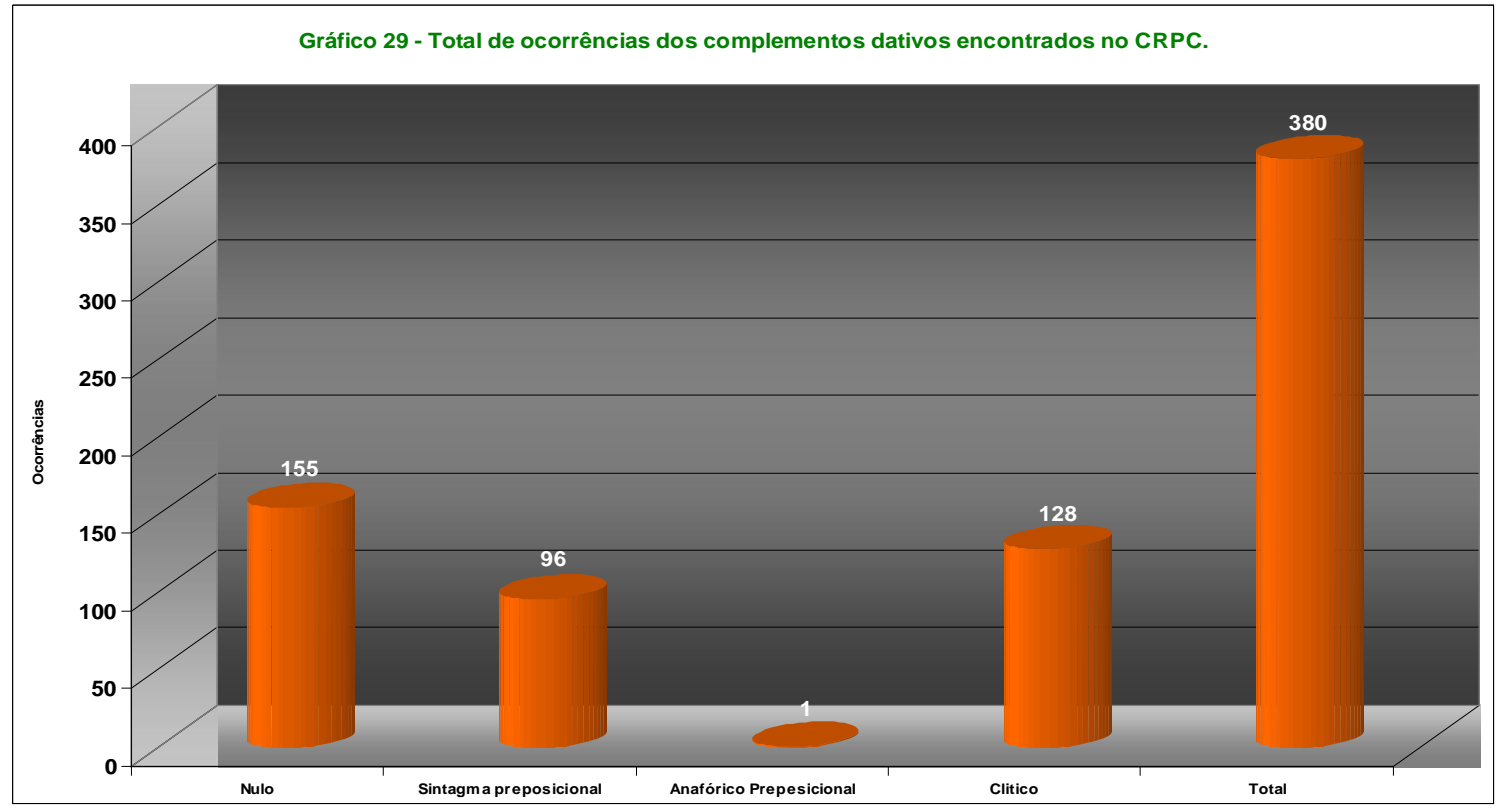

Fonte: Tabela 16

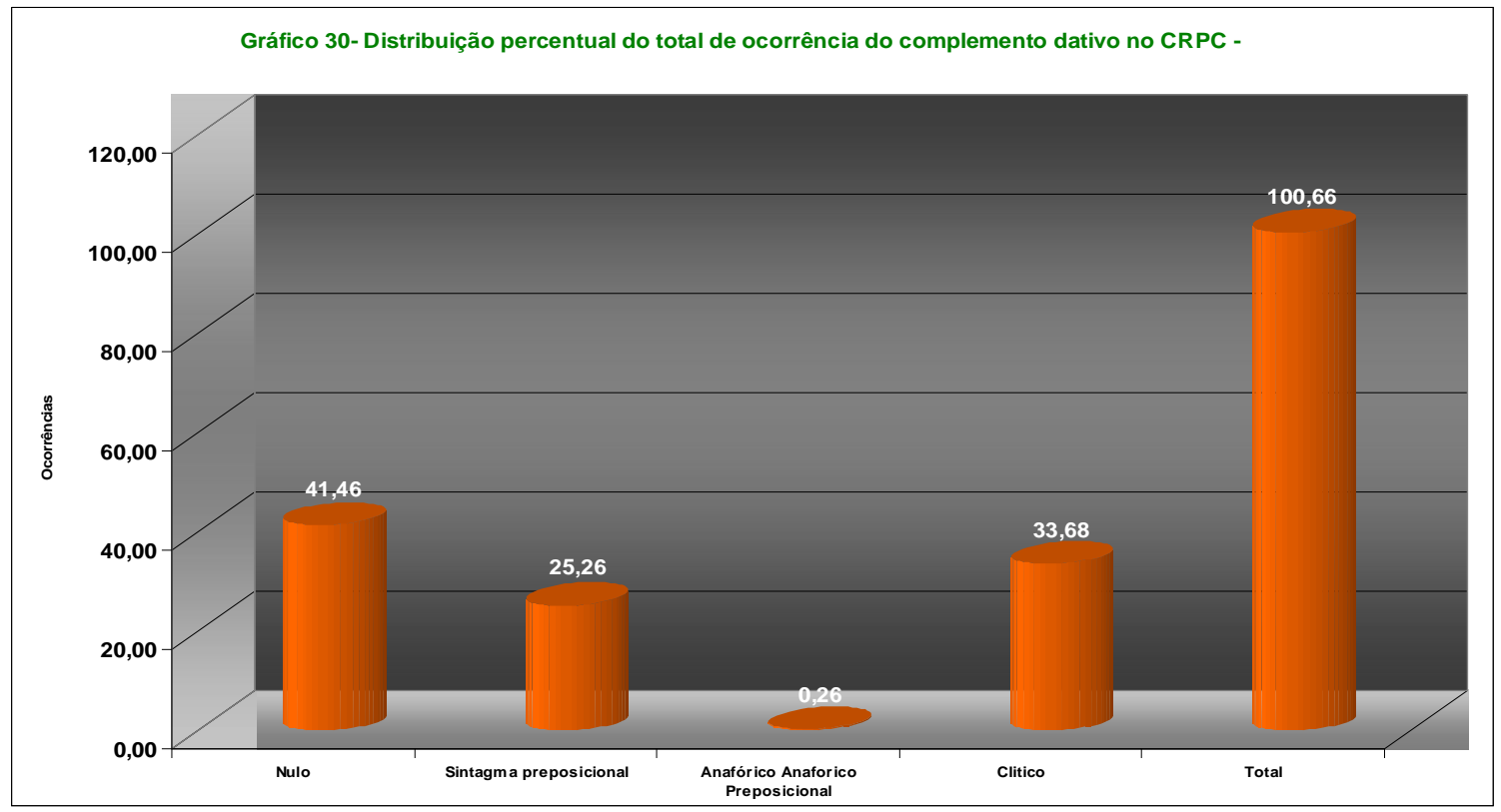

Fonte: Tabela 17 


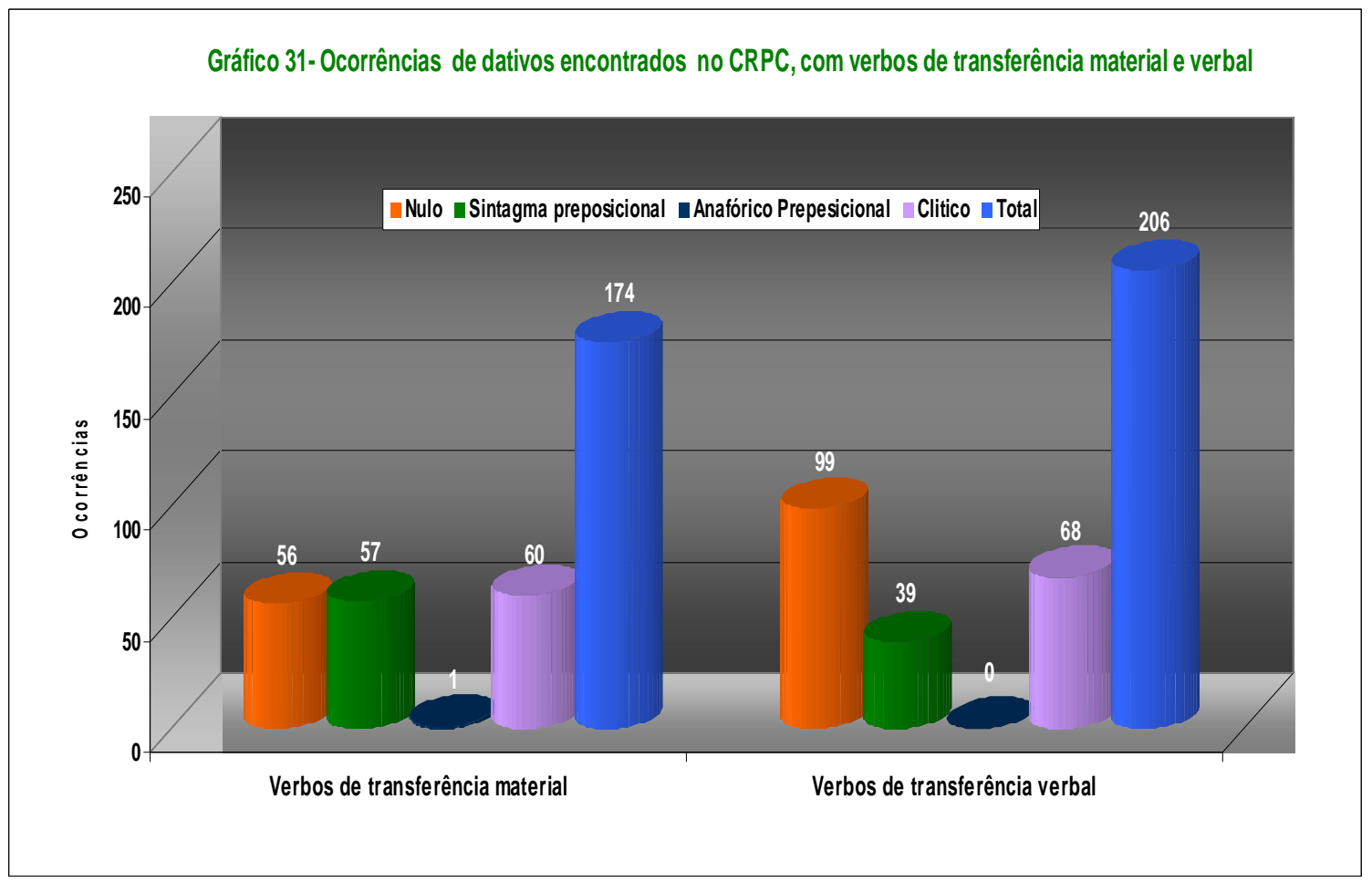

Fonte: Tabela 17

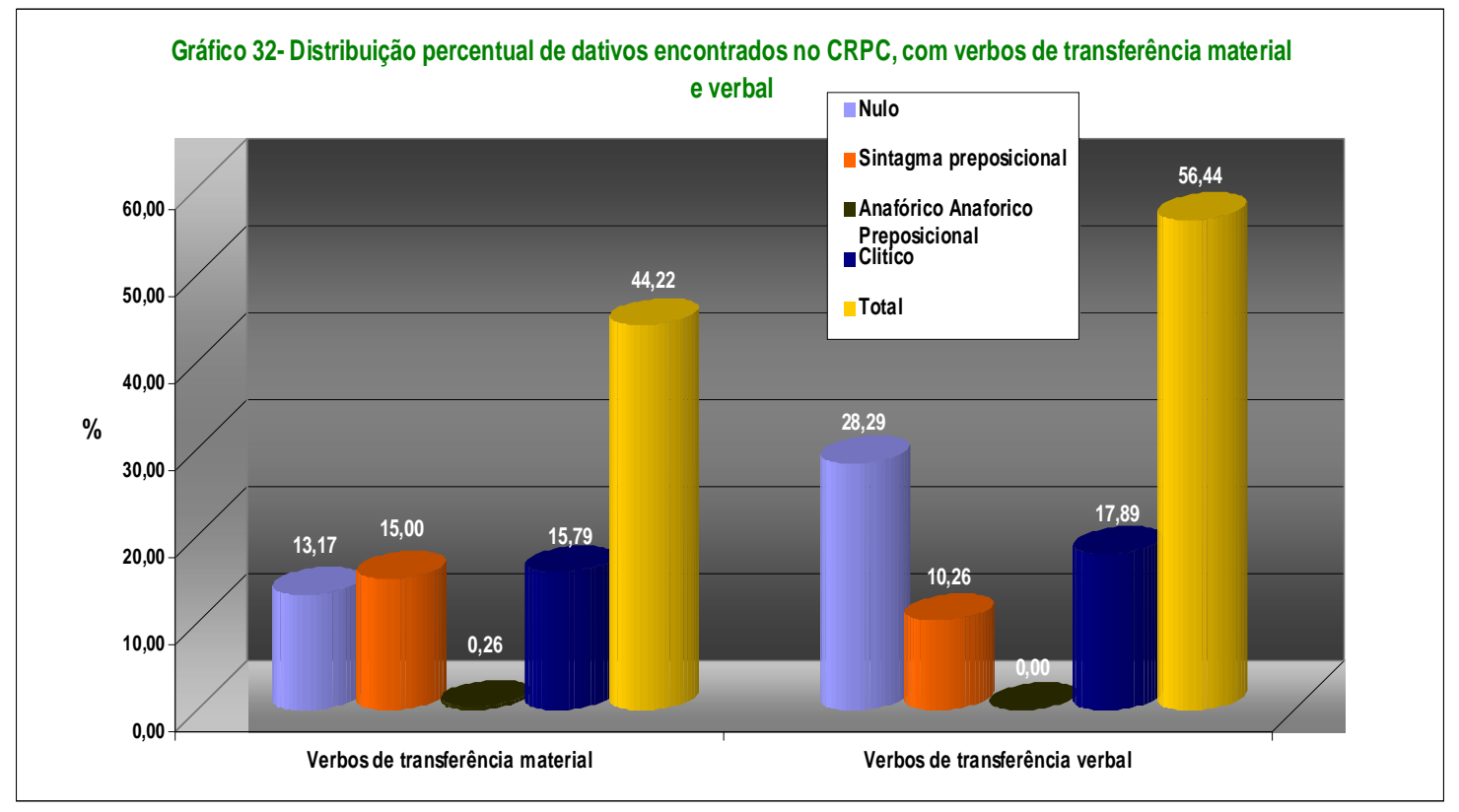

Fonte: Tabela 17 
A despeito de Mateus et al (2003, p.47) considerarem as realizações de objeto nulo como uma das diferenças entre PE e PB, nos gráfico 29 e 30 nota-se uma significativa presença de complementos nulos: 41,46\% (155 em 380), com uma realização maior do que as observadas nos clíticos: 33,68\% (128 em 380).

Os anafóricos tônicos foram as únicas realizações insignificantes, quase nulas (apenas 1 ocorrência em 380).

Os sintagmas nominais, cujas ocorrências totalizaram 96, com percentual de $25,26 \%$, apresentam realização significativa. Tal fato ocorre porque foram considerados todos os sintagmas nominais preposicionados como complemento de verbos ditransitivos.

Os Gráficos 31 e 32 revelam maior realização dos verbos ditransitivos com interpretação semântica de transferência verbal 56,44\% (206 em 380). Os verbos semanticamente interpretados como de transferência material tiveram um percentual de $44,22 \%$ (174 em 280).

Os dativos nulos e os clíticos tiveram maior realização nos verbos de transferência verbal, enquanto os sintagmas nominais ocorreram mais em verbos de transferência material. $O$ único caso de anafórico tônico preposicionado ocorreu com um verbo de transferência material.

\subsubsection{Ocorrências de complementos dativos com objetos nulos}

A Tabela 18 e o Gráfico 33 apresentam o número de ocorrência dos dativos nulos com verbos de transferência material e de transferência verbal, considerandose o tipo de oração em que tais dativos se realizam. A tabela 19 e o Gráfico 34 apresentam a distribuição percentual dessas mesmas ocorrências. 
Tabela 18 - Ocorrências de dativos nulos encontrados no CRPC, com verbos de transferência material e verbal, segundo o tipo de oração

\begin{tabular}{|l|r|r|r|}
\hline & \multicolumn{1}{|c|}{$\begin{array}{c}\text { Verbos de } \\
\text { transferência material }\end{array}$} & $\begin{array}{c}\text { Verbos de } \\
\text { transferência verbal }\end{array}$ & \multicolumn{2}{|c|}{ Total } \\
\hline Sentença Raiz & 9 & 3 & 12 \\
\hline Subordinada & 19 & 26 & 45 \\
\hline Segunda Coordenada & 16 & 10 & 26 \\
\hline Principal & 7 & 56 & 63 \\
\hline Primeira Coordenada & 5 & 3 & $\mathbf{1 5 4}$ \\
\hline Total & $\mathbf{5 6}$ & $\mathbf{9 8}$ & \\
\hline
\end{tabular}

Fonte: Inquéritos do corpus CRPC

Tabela 19 - Distribuição percentual de dativos nulos encontrados no CRPC, com verbos de transferência material e verbal, segundo o tipo de oração

\begin{tabular}{|l|r|r|}
\hline & \multicolumn{1}{|c|}{$\begin{array}{c}\text { Verbos de } \\
\text { transferência material }\end{array}$} & \multicolumn{1}{c|}{$\begin{array}{c}\text { Verbos de } \\
\text { transferência verbal }\end{array}$} \\
\hline Sentença Raiz & 16,07 & 3,06 \\
\hline Subordinada & 33,93 & 26,53 \\
\hline Segunda Coordenada & 28,57 & 10,21 \\
\hline Principal & 12,50 & 57,14 \\
\hline Primeira Coordenada & 8,93 & 3,06 \\
\hline Total & $\mathbf{1 0 0}$ & $\mathbf{1 0 0}$ \\
\hline
\end{tabular}

Fonte: Inquéritos do corpus CRPC 


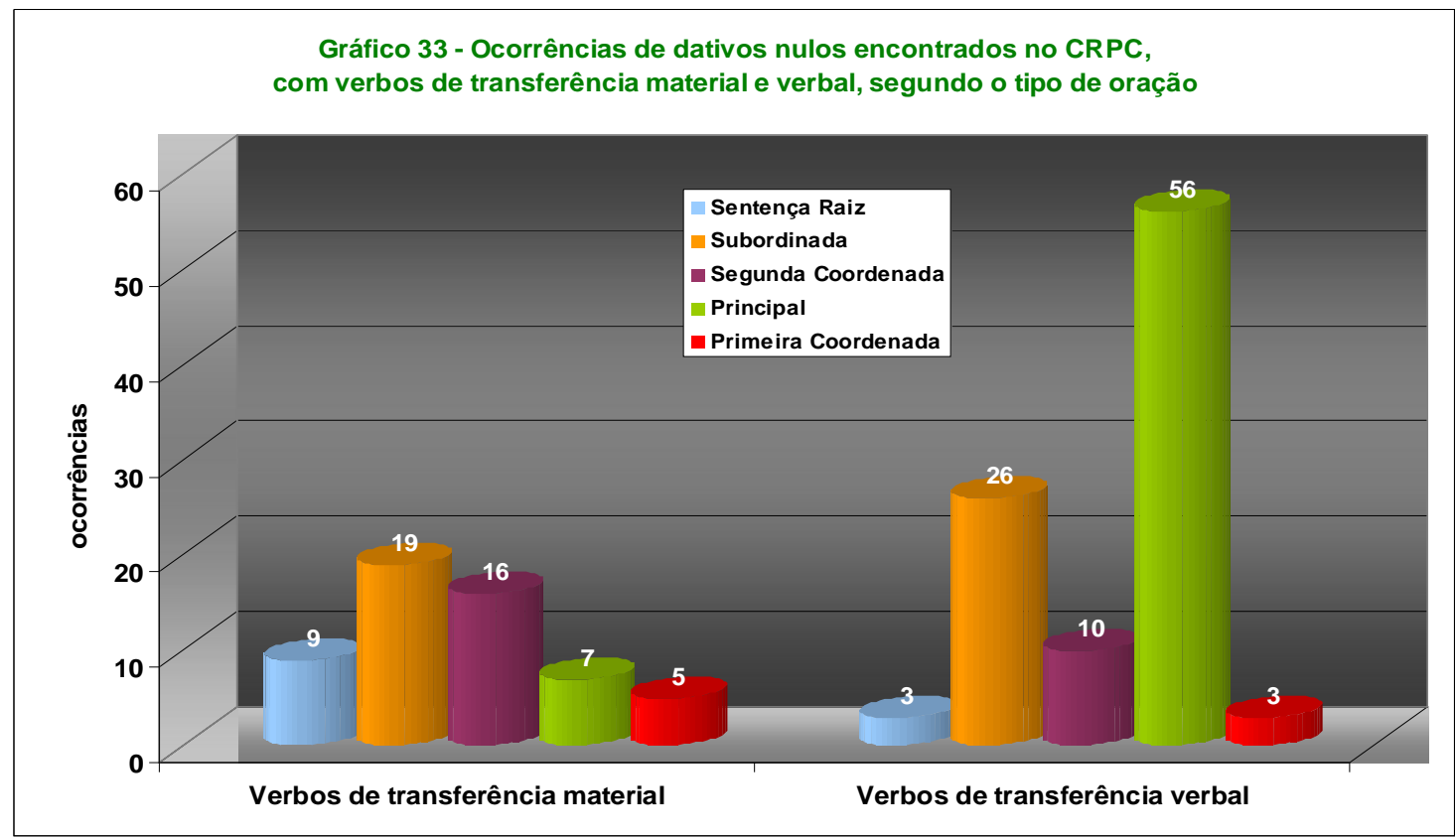

Fonte: Tabela 18

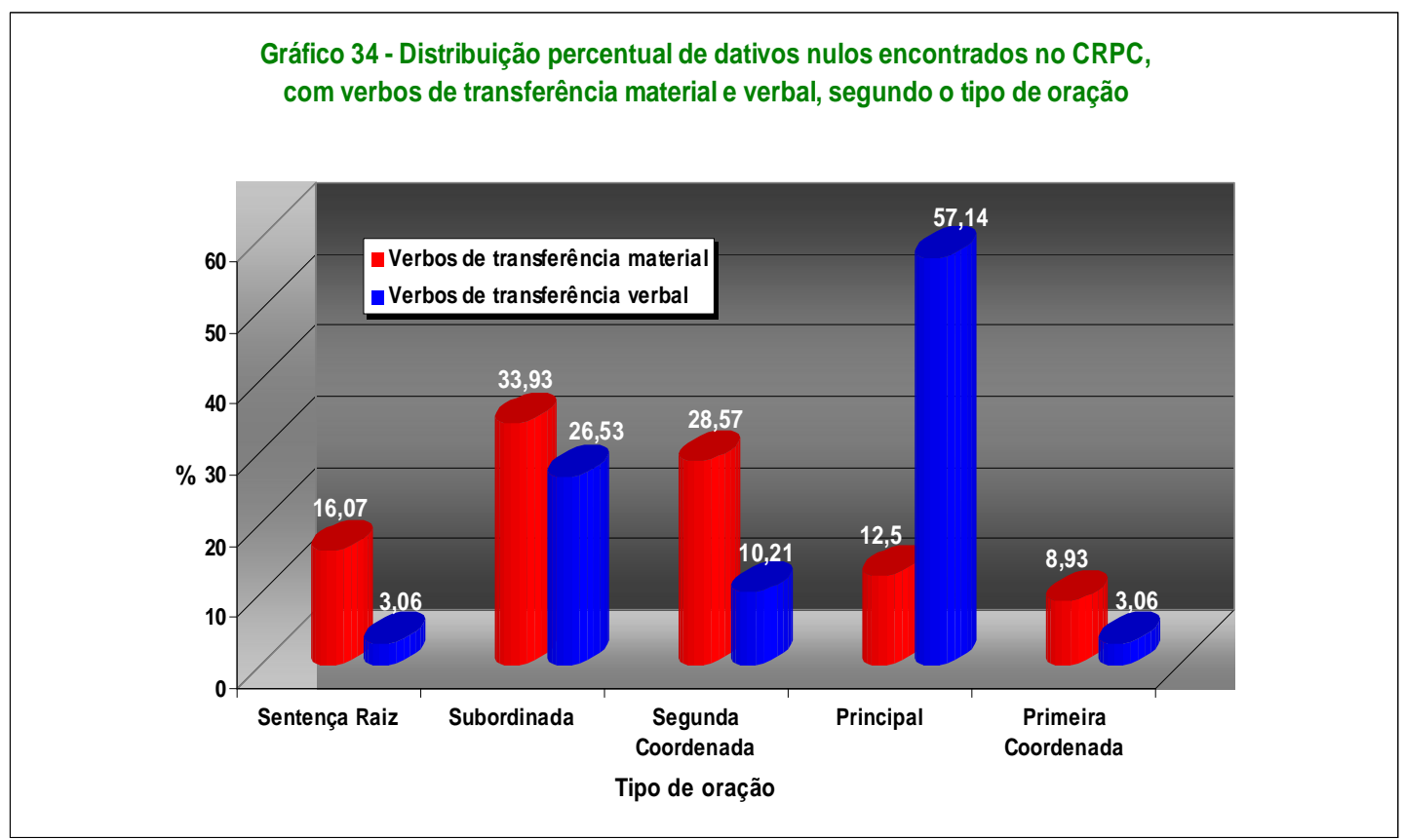

Fonte: Tabela 19

Percebe-se, nas Tabelas 18 e 19 e nos Gráfico 32 e 34, maior incidência de dativos nulos com verbo de transferência verbal, num percentual de $28,29 \%$. Os 
dativos nulos com verbo de transferência material apresentam um percentual de $13,17 \%$ de realizações.

Observem-se os exemplos de 17 a 31 retirados do CRPC:

(17) Eles gostam, principalmente a gente damos [ ] aqui um cabrito que eles adoram (inq.41)

(18) Inclusivamente chegava-se ao apuro de ter que pedir [ ] autorização, se fosse necessário uma operação (inq.53 )

(19) X: praticamente é mais serviço de escritório embora às vezes também vá para a rua entregar carros. (inq.109)

(20) X: e, e ele vai recebendo de, de pessoas, voluntariamente que queiram dar dinheiro (inq. 111)

(21) X: não, os jornais, apesar de ter encarecido, cada vez se vendem [ ] mais, cada vez se vendem [ ] muitos jornais (Inq. 502)

(22) X: que eles têm mobílias e têm umas coisas e têm os pais que [ ] dão as mobílias e mais não sei quê, tal.( Inq . 377)

(23) $\mathrm{x}$ : pois tem que apresentar,[ ] mas se ela não voltar a vacinar-se )novamente, (inq. 529)

(24) x: eles dão uma opinião e eu dou[ ] outra, gosto de sugerir e, e, e...

Claro, normalmente, nem concordo - (inquérito 832)

(25) leites e depois até dos três meses começa-se a dar[ ] umas farinhas simples,(inquérito 1009)

(26) Telefonei para cima e disse[ ]: «menina, o senhor np não está?» (inq. 22)

(27) Eu portanto eu dizia[ ] que neste mundo frio, engessado, cheio de máquinas, que nós não podíamos

(28) E, então, eu disse[ ]: «espera aí um bocado.» ( inq.106 ) 
(29) X: tava uma mesa completa de senhoras e senhores e eu olhei para ele e disse[ ]: «Olhe! A sua salvação é estar a sua senhora em frente e tar aqui mais umas senhoras; inq. 248

(30) que a mãe tinha medo. E eu dizia:[ ] «mas como é que é possível tu teres medo duma coisa que é tua?» inq. 455

(31) que foi lá uma vez lá um, um frade perguntar se eu queria assinar a revista eu disse[ ] que não inq. 479

As sentenças dos exemplos de (17) a (31) representam ocorrências do complemento dativo nulo, realizadas com verbos tanto de transferência material como de transferência verbal. Em quase todas as sentenças, o complemento nulo é identificado na própria sentença ou no contexto. A sentença de número (19) apresenta o complemento nulo lexicalizado, ou seja, não há, no contexto do discurso ou da sentença, nenhuma expressão à qual o verbo entregar possa se referir. No entanto, sabemos que a grelha temática do verbo comporta; (i) um argumento externo (sujeito agente),(ii) um argumento interno objeto direto, semanticamente interpretado como tema e(iii) um argumento interno objeto indireto, semanticamente interpretado como recipiente. Vale ressaltar que esse exemplo não é um caso isolado; há outras ocorrências semelhantes no corpus como em (21).

As realizações com dativos nulos com verbos de transferência verbal ocorrem, muitas vezes, em orações principais, sendo o argumento interno - objeto direto representado por um CP, conforme se observa nos exemplos de (26) a (31). Tal fato foi observado também no Português Oral Culto de Fortaleza.

As Tabelas 18 e 19 apresentam as realizações dos dativos nulos não só em referência aos verbos de transferência material e transferência verbal, mais também em relação aos tipos de sentença em que tais complementos ocorrem. Através dos Gráficos 33 e 34 visualizamos a quantificação das ocorrências, considerando as sentenças de sua realização, bem como sua distribuição percentual.

Os resultados evidenciam que ocorreram objetos nulos em todos os tipos de oração. Tal fato foi também observado por Cyrino (1999, p 617) ao estudar objetos diretos e indiretos nulos no PB. 
No cômputo geral, os dativos nulos tiveram uma realização expressiva nas orações principais, com 40,90\% das ocorrências. (63 em 154); Tal resultado coincide também com os de Cyrino (1999 p. 617) em estudos de complementos nulos no PB. A segunda maior realização de complementos nulos ocorreu em orações subordinadas $29,22 \%$ (45 em 154). A menor quantidade de dativos nulos ocorreu nas primeiras coordenadas, num percentual de 7,69\% (8 em 154). Esses resultados diferem um pouco das tabelas e dos gráficos porque estamos falando de resultados gerais, ou seja, o percentual da soma das realizações dos verbos de transferência material e transferência verbal.

Em relação ao objeto indireto nulo, Mateus et al (2003, p.211 e 886-889) observam que os objetos indiretos também podem ser nulos, em determinados contextos. Afirmam, também, que tais objetos só podem ser realizados em frases principais coordenas ou não e em frases subordinadas complementos de verbos, ou seja, nas subordinas substantivas, esclarecendo que esses complementos não podem ser realizados em orações subordinadas adjetivas ou adverbiais.

Outra consideração feita pelas autoras é que o português aceita mais o uso de complementos nulos que outras línguas românicas, em construções sentidas como ligeiramente marginais no PE padrão.

Na "ótica" de Mateus et al, as sentenças (20) e (22) seriam mal construías em PE porque estão violando princípio referente ao tipo de oração em que se permitem tais complementos. O interessante é que Mateus et al dizem ser "não-normativas".

\subsubsection{Ocorrências de dativos realizados com sintagmas nominais com verbo de transferência material, segundo o tipo de oração}

As Tabelas 20 e 21 apresentam as ocorrências os dativos realizados com sintagmas nominais com verbos de transferência material, bem como sua distribuição percentual, considerando-se o tipo de oração em que tais dativos se 
realizam. Através dos gráficos 35 e 36, temos uma melhor visualização dessas ocorrências, com a respectiva distribuição percentual.

Tabela 20 - Ocorrências de sintagmas nominais encontrados no CRPC, com verbos de transferência material, com preposição a para e a preposição a, segundo o tipo de oração

\begin{tabular}{|l|r|rr|r|}
\hline & \multicolumn{2}{|c|}{$\begin{array}{c}\text { Preposição } \\
\text { para }\end{array}$} & \multicolumn{1}{c|}{$\begin{array}{c}\text { Preposição } \\
\text { a }\end{array}$} & \multicolumn{2}{c|}{ Total } \\
\hline Sentença Raiz & & 4 & 9 & 13 \\
\hline Subordinada & 2 & 21 & 23 \\
\hline Segunda Coordenada & 1 & 7 & 8 \\
\hline Principal & & 8 & 2 \\
\hline Primeira Coordenada & 0 & 2 & $\mathbf{5 4}$ \\
\hline Total & 0 & $\mathbf{4 7}$ & \\
\hline
\end{tabular}

Fonte: Inquéritos do corpus CRPC

Tabela 21 - Distribuição percentual de sintagmas nominais encontrados no CRPC, com verbos de transferência material, com a preposição para e a preposição a, segundo o tipo de oração

\begin{tabular}{|c|c|c|c|}
\hline & $\begin{array}{l}\text { Preposição } \\
\text { para }\end{array}$ & $\begin{array}{c}\text { Preposição } \\
\underline{a}\end{array}$ & Total \\
\hline Sentença Raiz & 7,41 & 16,67 & 24,08 \\
\hline Subordinada & 3,7 & 38,89 & 42,59 \\
\hline Segunda Coordenada & 1,85 & 12,96 & 14,81 \\
\hline Principal & 0 & 14,81 & 14,81 \\
\hline Primeira Coordenada & 0 & 3,7 & 3,7 \\
\hline Total & 12,96 & 87,03 & 100 \\
\hline
\end{tabular}

Fonte: Inquéritos do corpus CRPC

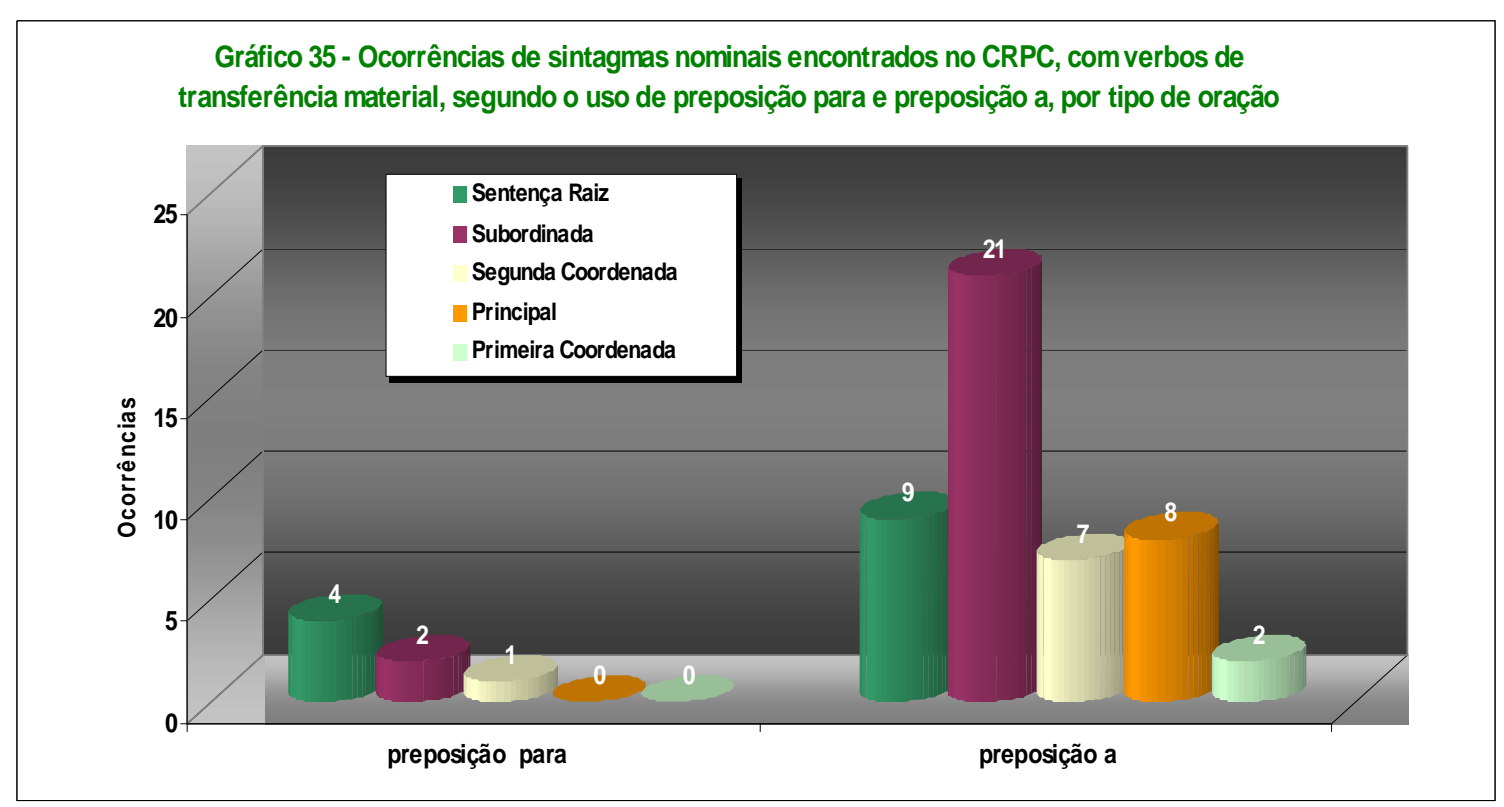

Fonte: Tabela 20 


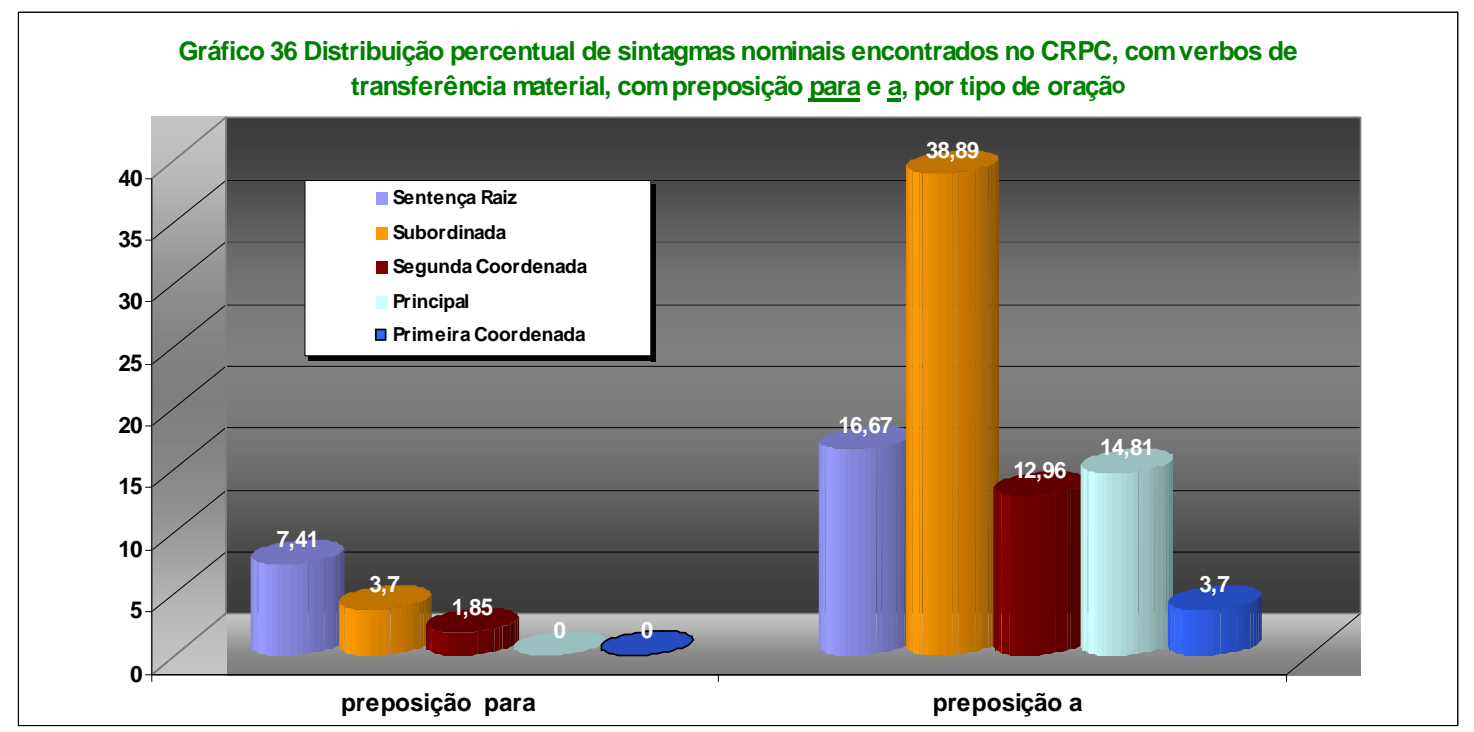

Fonte: Tabela 21

Observando-se as tabelas e os gráficos acima, percebe-se que os sintagmas nominais introduzidos pela preposição a apresentam uma realização de 87,03\% (47 em 54). Já os sintagmas nominais introduzidos pela preposição para apresentam uma realização bem inferior (7em 54), mesmo sendo considerado nesse cômputo sentenças, como nos exemplos em (44) e (49), em que o verbo apresenta uma conotação semântica de realização, sendo tais complementos considerados como PPs interpretados como beneficiários. Segundo Torres Morais (2006) essas ocorrências é que possibilitam a inserção do PE no contexto das realizações de alternância dativa.

Esses resultados confirmam a preferência do falante do PE pelo uso da preposição a, nos complementos dativos, apontando para o fato de que essa preposição faz parte de sua gramática interna, já que, conforme frisamos anteriormente, as realizações com PP não são complementos dativos. Os dativos, ou seja, os a-DPs realizam-se somente com a preposição funcional $a$.

No que tange ao tipo de oração, os complementos dativos denotam maior realização em orações subordinadas, com 42,59\% das ocorrências. Nas sentenças raiz, verificou-se uma realização também significativa, com um percentual de $24,08 \%$. 
Abaixo estão relacionados exemplos de ocorrências com sintagmas nominais dativos com verbos de transferência material introduzidos pelas preposições a e para:

(32) x:, ao domingo de manhã, o pai vai à fábrica dar de comer à bicharada (inq. 22)

(33) X: mas é que no meu tempo - agora já não, está tudo muito; (...) os catecismos, a gente dá os catecismos às crianças, (inq. 31 )

(34) a mãe, contudo, tem que pedir autorização ao pai, para tudo! em relação aos filhos. (inq.53)

(35) Tem que pedir autorização do pai para averbar os filhos no passaporte, (inq.53)

O exemplo em (34) apresenta uma sentença comum verbo ditransitivo de transferência material em que ocorre um dativo representado pela expressão ao pai em que o a é uma preposição funcional, ou seja, um marcador de caso dativo. $O$ complemento dativo é semanticamente interpretado como fonte. Em (35), ocorre uma ditransitiva preposicionada em que o PP apresenta conotação semântica também de fonte.

Os dois exemplos apresentam a alternância dativa identificada no PE por Torres Morais (2006), conseqüentemente, a construção em (34) é uma construção aplicativa, em que o argumento dativo é licenciado por um núcleo aplicativo e não pelo verbo. É interessante observar que o mesmo falante alterna a construção de complemento dativo com a ditransitiva preposicionada.

(36) x: não é? por outro lado, o juiz também pela sua alta moralidade é uma pessoa que procura exigir insensivelmente dos outros um comportamento demasiadamente perfeito. (inq.108)

Observe-se em (36) mais um exemplo de alternância dativa: a sentença apresenta o verbo ditransitivo exigir, em que há um PP introduzido pela preposição de, o qual apresenta a interpretação semântica de fonte: dos outros. 
(37) x: é pena, é pena. sempre dão aos pobres, mas já não é aquela quantia, (inq. 111)

(38) $x$ : ou então, a pessoa não... outra pessoa qualquer pede ao mordomo, «eu gostava que minha filha (inq.111)

(39) x: sabes que a gente só tem jeito é para arranjar noivas aos outros! (inq 122)

(40) a querer meter conversa e, e nós demos logo trela à miúda (inq 122)

(41) vai lá buscar uma caralhota para a avó!» sem, sem nada, (inq. 248)

(42) ou chova ou faça sol, se não ganhar tenho que pagar sempre aquele dinheiro ao, ao café, ao dono do café (inq.328)

(43) Era um bocado do Sebastião da Gama do «Diário», que ele diz: «eu não gosto de impingir versos aos meus alunos, ( inq.93 )

Observe-se que em (43), temos um verbo ditransitivo, com tipologia semântica de movimento psicológico, em que há uma aproximação abstrata entre duas entidades, no caso o argumento externo $(E u)$ que representa o poeta e o argumento interno dativo os alunos. A preposição introdutória de tal complemento é o a, que detém aí o estatuto de marcador de caso dativo, não tendo, portanto, um caráter lexical.

(44) por exemplo, dar força ao cão, dar força, isto é, açodá-lo, para esse cão ser útil, inq. 564

Em (44) o verbo ditransitivo dar encerra a idéia de transferência em que o argumento externo transfere algo para o argumento interno a-DP (uma situação eventiva de posse, segundo Mateus et al. (2003). Embora o verbo conserve a sua grelha temática, ou seja, tem um argumento externo e dois argumentos internos: um DP-tema e um DP-dat, tal verbo apresenta um certo esvaziamento lexical ${ }^{41}$ que permite a centralização semântica na expressão nominal força, podendo, neste caso, o verbo e o argumentos interno (objeto direto) serem substituídos pelos verbos reforçar ou fortificar.

${ }^{41}$ Mateus et alii faz referência a tal esvaziamento lexical. 
(45) x: O lagarto é que não faz mal ao homem. inq. 564

Em (45), o verbo fazer, interpretado semanticamente como de construção é um também um verbo leve (sofreu esvaziamento lexical, com a transferência semântica para o DP-tema mal), podendo a expressão fazer mal ser substituída pelo verbo maleficiar. A grelha temática do verbo foi preservada, pois existe o argumento externo- agente, o DP-tema mal, sendo o DP-dat ao homem interpretado como beneficiário da ação.

(46) X: e essa gente bordou coisas para ela (inquérito 816)

No exemplo em (46), temos um verbo ditransitivo de criação ou construção, (segundo Torres Morais, 2006, p.252) havendo aí um exemplo de ditransitiva preposicionada. Embora estejamos trabalhando só com os verbos de transferência, especialmente os de transferência material e verbal, achamos oportuno referir essa realização do PE, O PP para ela tem conotação semântica de beneficiária. Esta sentença infringe um dos cânones lingüísticos da gramática portuguesa, pois no PE, só é possível preposicionar um anafórico com a preposição a e, em contexto de redobro do clítico ou em sentenças em que haja expressões como só, até, mesmo, ou em construções de tópico.

(47) a: mas quais são assim os tipos de artigos que tu vendes mais? (inquérito 1093) X: eu? para espanhóis ou para portugueses?

(48) c: eu assim chego a casa, faço o chá para ele e para mim, ( Inq.1383)

Em (48), temos também uma ditransitiva preposicionada em que o verbo apresenta uma conotação semântica de construção, tendo o PP para ele e para mim tem uma conotação semântica de beneficiário. Embora esse tipo de verbo não seja escopo do nosso trabalho, estamos fazendo referência a ele, sobretudo pelo emprego do pronome ele realizado como complemento verbal. Sabemos que o PE faz restrição a tal uso, permitido nesta sentença, por conta do caráter contrastivo entre ele e mim. 


\subsubsection{Ocorrências de dativos realizados com sintagmas nominais com verbo de transferência verbal}

$\mathrm{Na}$ Tabela 22, apresenta-se o número de ocorrência dos complementos dativos representados por sintagmas nominais com verbos de transferência verbal, por tipo de oração, com a preposição que os introduz. A Tabela 23 apresenta 0 percentual de realização desses dativos. Nos Gráficos 37 e 38 visualizamos a quantificação das ocorrências desses complementos e a sua distribuição percentual.

Tabela 22 - Ocorrências de sintagmas nominais encontrados no CRPC, com verbos de transferência verbal, com preposição para e preposição a, segundo o tipo de oração

\begin{tabular}{|l|cr|r|r|}
\multicolumn{1}{c}{ Tipo de oração } & $\begin{array}{c}\text { Preposição } \\
\text { para }\end{array}$ & $\begin{array}{c}\text { Preposição } \\
\text { a }\end{array}$ & Total \\
\hline Sentença Raiz & & 0 & 2 & $\mathbf{2}$ \\
\hline Subordinada & 0 & 11 & $\mathbf{1 1}$ \\
\hline Segunda Coordenada & 0 & 5 & $\mathbf{5}$ \\
\hline Principal & 5 & 15 & $\mathbf{2 0}$ \\
\hline Primeira Coordenada & 0 & 1 & $\mathbf{1}$ \\
\hline Total & $\mathbf{5}$ & $\mathbf{3 4}$ & $\mathbf{3 9}$ \\
\hline
\end{tabular}

Fonte: Inquéritos do CRPC

Tabela 23 - Distribuição percentual de sintagmas nominais do CRPC, com verbos de transferência verbal, com preposição para e preposição a, segundo o tipo de oração

\begin{tabular}{|c|c|c|c|}
\hline Tipo de oração & $\begin{array}{l}\text { Preposição } \\
\text { para }\end{array}$ & $\begin{array}{c}\text { Preposição } \\
\underline{\underline{a}}\end{array}$ & $\begin{array}{c}\text { Total } \\
\%\end{array}$ \\
\hline Sentença Raiz & 0 & 5,12 & 5,12 \\
\hline Subordinada & 0 & 28,21 & 28,21 \\
\hline Segunda Coordenada & 0 & 12,82 & 12,82 \\
\hline Principal & 12,82 & 38,46 & 51,28 \\
\hline Primeira Coordenada & 0 & 2,56 & 2,56 \\
\hline Total & 12,82 & 87,17 & 100 \\
\hline
\end{tabular}

Fonte: Inquéritos do CRPC 


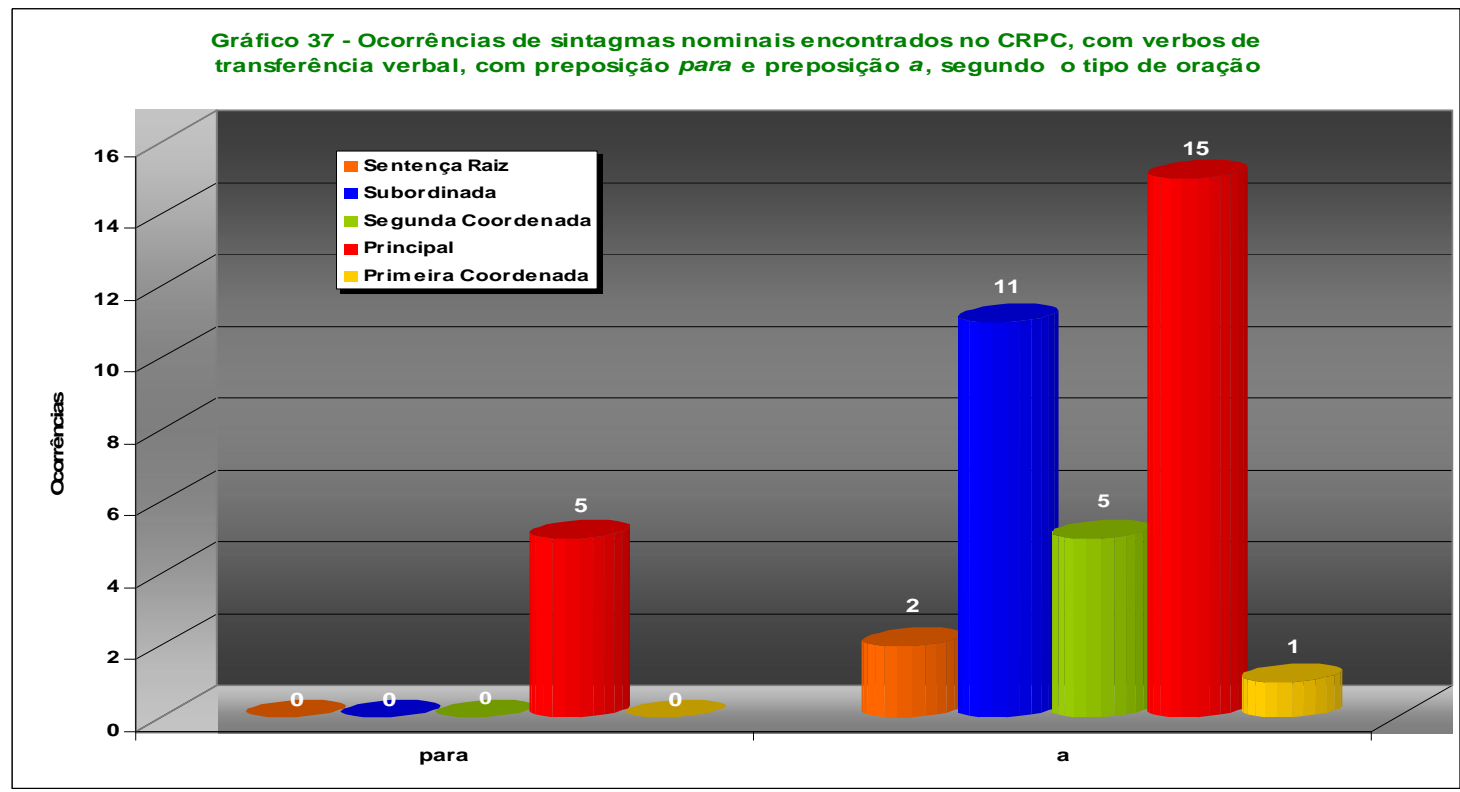

Fonte: Tabela 22

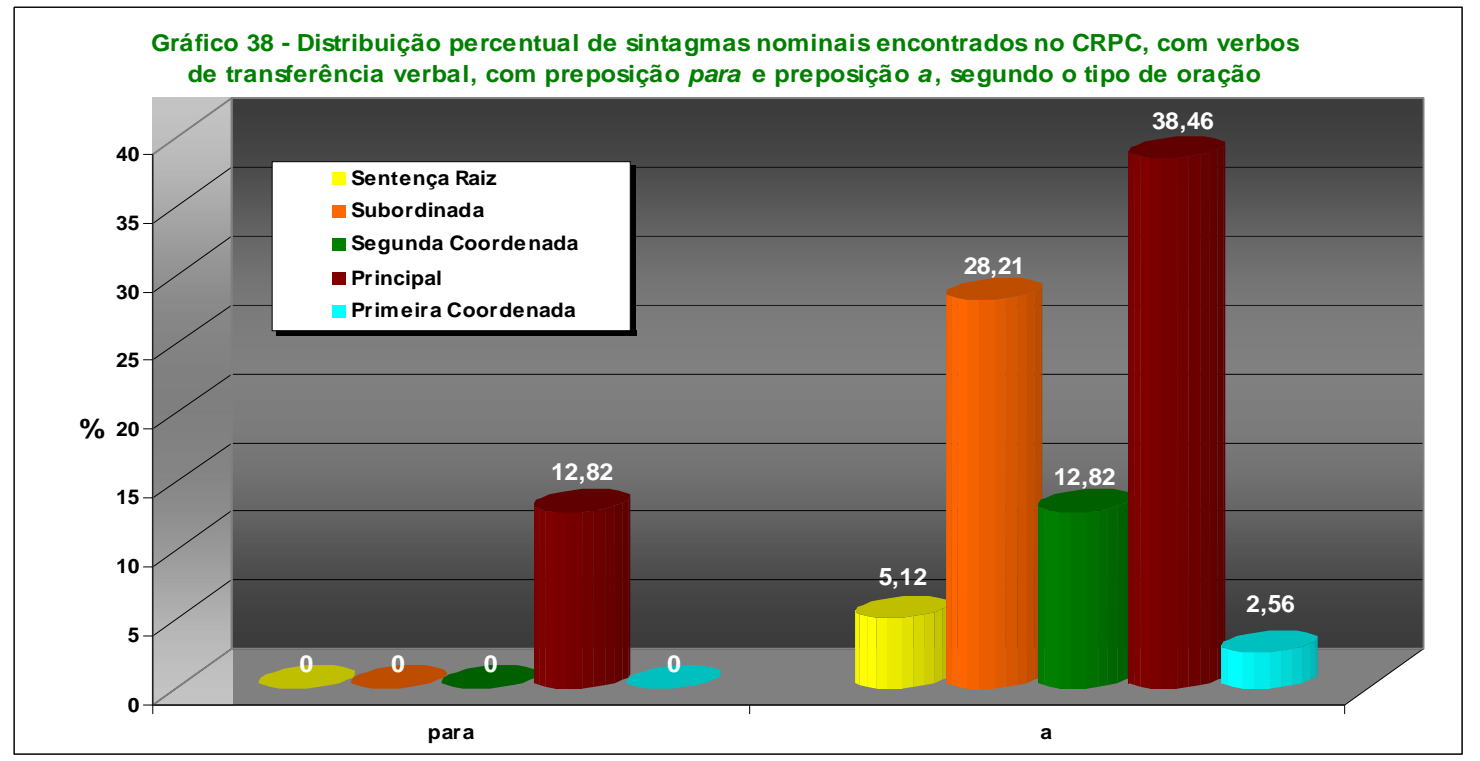

Fonte: Tabela 23

As ocorrências e percentuais de realização dos complementos visualizadas nas tabelas 22 e 23 e demonstradas nos gráficos 37 e 38 apresentam uma significativa realização da preposição a, com um percentual de 87,17\% "(34 em 39). As realizações com a preposição para se limitaram a um percentual de $12,82 \%$ (5 
em 39) Tal fato demonstra que, diferentemente do PB, a preposição a é bastante produtiva

Os complementos dativos tiveram uma realização bastante significativa nas orações principais, com um percentual de 51,28\% (20 em 39); a segunda realização dos dativos ocorreu nas orações subordinadas, com um percentual de 28,21\% (11 em 39). O tipo de oração em que se deu menor ocorrência dos dativos foi a primeira coordenada. Tal fato já foi observado em vários contextos deste estudo.

As sentenças dos exemplos de (49) a (56) apresentam o argumento dativo com conotação semântica de recipiente realizado com o uso da preposição para, construção considerada marginal no PE. Torres Morais e Berlinck (2004) citam um exemplo extraído do Cordial-Sin (aqui renumerado de como 49) dativo introduzido pela preposição para também com o verbo dizer, conforme se observa em (49).

(49) "E então, (...) dizia-Ihe o avô para o neto, dizia: é a coisa mais fácil que há" (extraído do Cordial-Sin conf. Torres Morais e Berlinck, 2004)

(50) acabam de comer e diz o pai para o filho: «rapaz, vai lavar a boca», (inq. 22)

(51) E fui tolhida de medo. Mas quando cheguei ao meio do caminho, com certeza, eu disse assim para uma senhora que ia do meu lado: «0 avião já subiu?» (Inquérito 894)

(52) X: e à vinda para cá, quando foi ali a bucelas, digo eu assim para um colega meu: «olha, vai andando que eu agarro-te já.» Inquérito 913

(53) Anda que se farta, eu ia muito devagarinho no meu morrizinho todo engalinhado, ia dizendo para a minha mãe: «olhe isto aqui tem uma vista linda!» ( inq.109 )

(54) um dos $s(.$.$) um deles, ou o \mathrm{np}$, ou lá um dos camaradas, disse para os soldados, tomem cuidado,( inq 1071

(55) - eles diriam de certeza, ainda não têm aquela... medo de dizer à professora que, que não gostaram. ( inq.93 ) 
Em (55), temos o verbo dizer ditransitivo, com interpretação semântica de transferência verbal e com a mesma configuração sintática: um argumento externo agente, um argumento interno tema e um argumento interno recipiente. $O$ argumento interno (objeto indireto) recipiente da ação é representado por um sintagma nominal pleno a professora, introduzido pela preposição $a$, marcadora de Caso dativo.

(56) ...e depois relatava [ ] exactamente uma experiência pessoal. ( inq.93 ) a palavra ao aluno recuperada no contexto.

Em (56), o verbo relatar é um verbo de três lugares (ditransitivo), cuja grelha temática é saturada com um argumento externo sujeito (agente), um argumento interno objeto direto (tema) e um argumento interno objeto indireto. Tal verbo é considerado semanticamente como de transferência verbal, pois existe um agente que transmite um conhecimento a um recipiente da ação verbal. Ocorre que esse argumento interno (objeto indireto) não está realizado foneticamente na sentença, sabe-se que é ao aluno, recuperado no contexto.

(57) x: pessoas que têm fé, aprometem ao senhor são Brás, inquérito 1055

Em (57), o verbo ilocutório ${ }^{42}$ prometer é um verbo de três argumenots, com conotação semântica de transferência verbal, em que o argumento externo as pessoas que têm fé faz uma transferência verbal, através do ato de fala de prometer a garganta, embora no discurso indireto, tal ato seja representado pelo DP-tema garganta (nulo recuperado no contexto). Tal transferência é feita para o DPdat argumento internos a São Brás. Em relação ao argumento interno DP-tema garganta, que consideramos como um nulo recuperado no contexto, pode ter havido um erro de grafia, pois aparece no inquérito como aprometem. É possível que esse a seja um clítico acusativo referente à palavra garganta

\footnotetext{
42 Segundo Dubois et al (1973, p. 330), na perspectiva de Austin, verbo ilocutório é aquele que realiza ou tende a realizar a ação nomeada. O verbo prometer é considerado um verbo ilocutório de atitude.
} 


\subsubsection{Ocorrências de dativos realizados com anafóricos tônicos com verbo de transferência material}

Considerando que a realização de anafóricos tônicos foi quase nula, não se elaboraram gráficos e tabelas com registro.

Em PE, o argumento dativo geralmente é introduzido pela preposição a, que é uma preposição funcional, que tem o papel de marcar o Caso dativo. $\mathrm{O}$ uso da preposição para indica a ocorrência de uma ditransitiva preposicionada, sendo o para, nesse caso, uma verdadeira preposição com conteúdo semântico, ou seja, é uma preposição lexical e não um simples marcador de Caso dativo.

Observamos no corpus que os pronomes anafóricos tônicos preposicionados não representam uma estratégia para a substituição aos clíticos dativos de terceira pessoa. Esses anafóricos no PE só podem ser usados em contextos em que ocorre o redobro do clítico ou com expressões como só, até, mesmo. Também, admite-se seu uso no PE, com deslocamento para esquerda da sentença (construções de tópico). Nesses dois últimos casos, o redobro do clítico não é obrigatório. Outro fato a considerar é que em tais casos, a preposição a ser usada é sempre $a$.

O redobro do clítico no PE é pouco usado, razão por que expressões como a ele(s) a ela(s) são pouco encontradas neste corpus.

(58) Esta até é fornecedora de frangos, que eu compro a ela. (inq. 75 )

Em (58), observa-se uma oração relativa com uso do pronome ressumptivo, referido em Kato (1999). Existe aí um deslocamento à esquerda (construção de tópico), sendo o pronome ressumptivo co-referente não só à variável em LD, mas também ao pronome relativo, ou seja, a ela é co-referente à vendedora de frango e ao que relativo. É provável que tal construção seja considerada marginal no PE. Encontra-se também na literatura a denominação pronome lembrete em relação a esse a ela. É possível que haja aí uma construção de foco contrastivo (compro a ela, não a outra pessoa). 
O verbo comprar, no caso, é semanticamente um verbo de transferência material, só que tal transferência ocorre de forma diferente do verbo dar, uma vez que em comprar o argumento interno dativo (objeto indireto) é a fonte do benefício. Postulando-se a idéia de que, em (58), existe um verbo de transferência material, admite-se que existe um argumento interno (objeto), embora nulo-, algo a ser comprado. Tal elemento elíptico é o objeto nulo, que, no caso, é recuperado no contexto, pois se existe uma vendedora de frango e alguém compra a ela, deve ser frango o objeto comprado. Vale ressaltar que o pronome relativo que adquire uma interpretação meio dúbia, pois não fica muito claro se o que se refere realmente à vendedora de a frangos ou a frangos.

\subsubsection{Ocorrências de clíticos dativos realizadas com verbos de transferência material e verbal.}

Observem-se as Tabelas 24 e 25 que demonstram a realização do clítico no CRPC em verbos de transferência material e de transferência verbal, em relação às pessoas do discurso, representadas visualmente nos Gráficos 39 e 40.

Tabela 24 - Ocorrências do clítico dativo Ihe, em relação às pessoas do discurso, no CRPC, com verbos de transferência material e verbal

\begin{tabular}{|l|r|r|r|}
\hline \multicolumn{1}{|c|}{ Tipo de verbo } & Segunda pessoa & Terceira pessoa & \multicolumn{2}{|c|}{ Total } \\
\hline verbos de transferência material & 1 & 59 & 60 \\
\hline verbos de transferência verbal & 4 & 64 & 68 \\
\hline total & 5 & 123 & 128 \\
\hline
\end{tabular}

Fonte: Inquéritos do CRPC

Tabela 25 - Distribuição percentual do clítico dativo Ihe, encontrado no CRPC, em relação às pessoas do discurso, com verbos de transferência material e verbal

\begin{tabular}{|l|r|r|r|}
\hline \multicolumn{1}{|c|}{ Tipo de verbo } & Segunda pessoa & \multicolumn{1}{c|}{$\begin{array}{c}\text { Terceira } \\
\text { pessoa }\end{array}$} & \multicolumn{1}{c|}{ Total } \\
\hline verbos de transferência material & 0,78 & 46,09 & 46,88 \\
\hline verbos de transferência verbal & 3,13 & 50,00 & 53,13 \\
\hline total & 3,91 & 96,09 & 100,00 \\
\hline
\end{tabular}

Fonte: Inquéritos do CRPC 


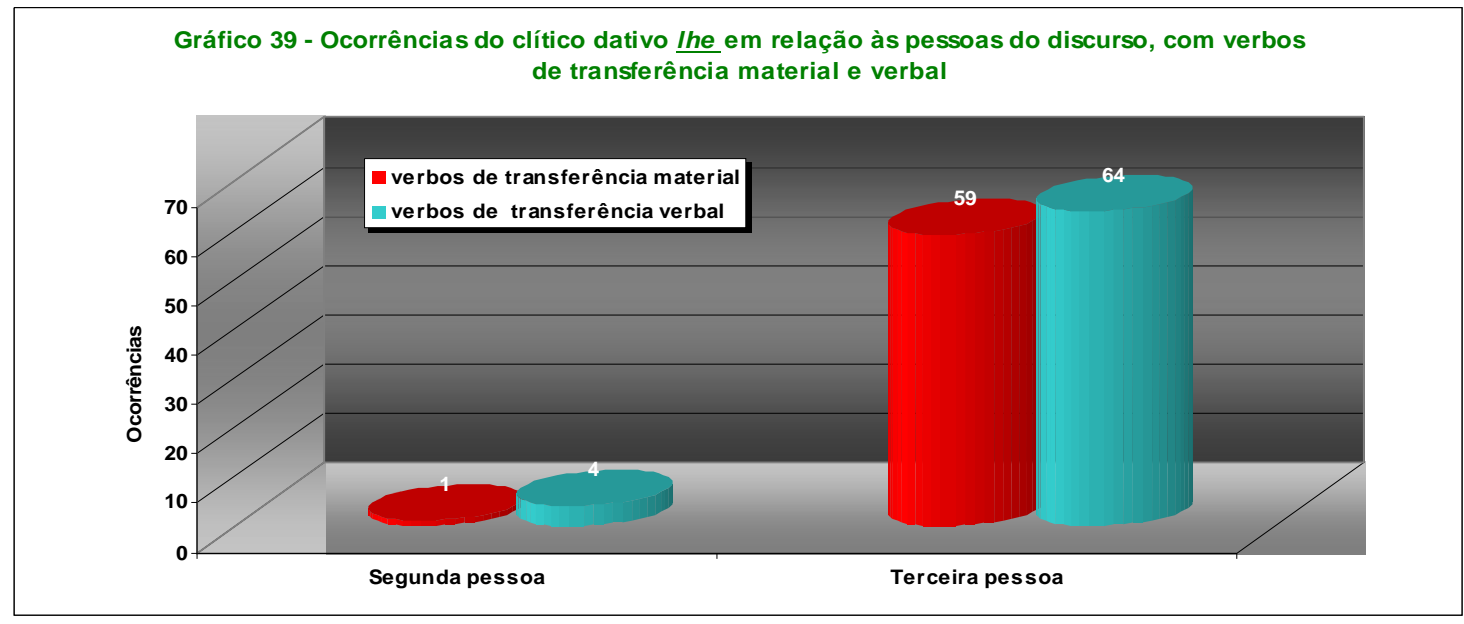

Fonte: Tabela 24

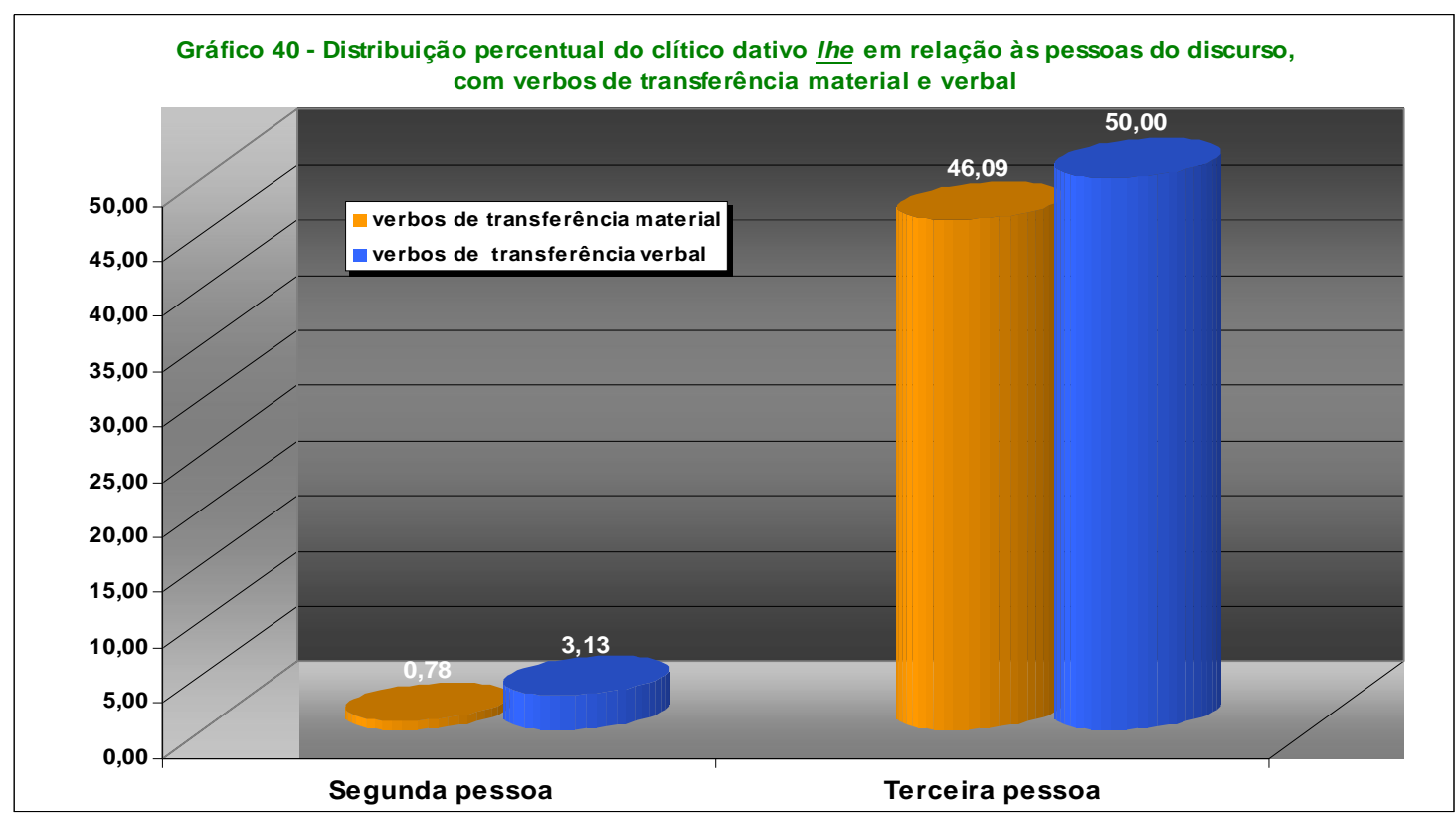

Fonte: Tabela 25

Os clíticos dativos estão sendo analisados em relação à interpretação semântica do verbo e à pessoa do discurso a que se referem. Nas tabelas 24 e 25 observa-se o número de realizações dos clíticos $/ h e(s)$ em referência à $2^{a}$ e $3^{\text {a }}$ pessoas, bem como sua distribuição percentual, considerando a tipologia semântica dos verbos de sua realização. Os Gráficos 39 e 40 oferecem uma visualização das realizações de tais clíticos com sua distribuição percentual. 
Das 128 ocorrências com clíticos, apenas 5 se referiram à segunda pessoa. Essa realização insignificante do clítico lhe em referência à segunda pessoa se deve ao fato de o tratamento familiar no PE ser o tu. Como não há essa confusão na concordância, pois o verbo, os oblíquos, os possessivos todos vão, via de regra, concordar com o tu, não há essa mescla de te e the, que possibilitaria muitas realizações de the em referência ao interlocutor.

Se comparado com o PB percebemos que o clítico dativo apresenta uma realização expressiva, no entanto em alguns contextos verbais tal clítico já é substituído pelos complementos nulos, esses últimos com vantagem, embora ,pequena.

Considerando que as realizações dos nulos no PE, além de sofrerem restrições contextuais ainda são consideradas meio marginais, estamos realmente diante de um fato surpreendente.

As ocorrências do clítico nos verbos de transferência material e verbal foram muito próximas: 60 realizações com os verbos de transferência material e $68 \mathrm{com}$ os verbos de transferência verbal, com uma distribuição percentual de 46,88\% e $53,13 \%$ respectivamente.

Observem-se algumas sentenças com o clítico the realizado com verbos de transferência material e verbal: da sentença 59 até a 63 os verbos apresentam conotação semântica de transferência material; da sentença 64 até 66 , os verbos possuem conotação semântica de transferência verbal.

(59) X: a gente pode encarar com um bicho desses se tiver deitado dá-Ihe uma pancada e matá-lo. (inq. 564)

$\mathrm{Na}$ sentença (59), o verbo ditransitivo dar, embora conserve a sua grelha temática, ou seja, tem um argumento externo e dois argumentos internos: um DP e um clítico com função argumental, apresenta certo esvaziamento lexical, é um verbo leve, referido em Mateus et alii (2003), que permite a centralização semântica na 
expressão nominal uma pancada, podendo, neste caso, o verbo e o argumento interno objeto direto serem substituídos pelo verbo espancar.

Esses fatos não invalidam, contudo, a função do clítico lhe como dativo, pois, como referido, a grelha temática do verbo foi conservada.

(60) x É. Queria que Ihe eles dessem trezentos escudos e ele dizia que não valia a pena porque o serviço que ele fez não valia esse dinheiro. (Inq. 1055)

A sentença em (60) realiza-se com verbo de transferência material, ou seja, um verbo que tem um argumento externo sujeito, semanticamente interpretado como agente, um argumento interno objeto direto (trezentos escudos) com papel semântico tema, e um argumento interno representado pelo clítico Ihe (objeto indireto), com papel semântico de recipiente. Nesse tipo de verbo, o argumento externo transmite ao argumento interno a posse de algo, estando esse algo contido no tema. Nesta sentença há uma realização curiosa: a colocação do clítico antecedendo o pronome forte eles e antes do verbo, referido por Martins (s.d.), como uma característica do português medieval, que não pertence mais à variedade padrão, mas é conservada em dialetos portugueses de Norte a Sul, fato observado pela autora no Corpus Dialectal com Anotação Sintáctica (Cordial - Sin).

(61) X: mas abrir-Ihes a janela da poesia» por aí adiante(inq.93 )

Em (61), aparece o dativo referido por Bechara (2003) como dativo livre ou de interesse, (dativo mediante o qual se indica de maneira secundária a quem aproveita ou prejudica a ação). Para Torres Morais (2007), a sentença em (45) realiza-se com um verbo causativo, em que o argumento interno objeto indireto tem a conotação semântica de afetado. Embora os verbos estudados neste trabalho sejam preferencialmenrte os ditransitivos com interpretação semântica de transferência material e verbal, tal dativo nos interessa por conta de ser representado por um clítico.

(62) Porque tenho que Ihes pagar escola... (inq.476)

(63) Porque tenho que Ihes pagar... cursos... (inq.476). 
As sentenças em (62) e (63) apresentam a mesma estrutura sintática e a mesma grelha temática: um argumento externo com papel temático agente e dois argumentos internos com papel temático tema e recipiente; portanto, temos mais uma vez um verbo ditransitivo com papel semântico de transferência material, em que o agente transfere a posse de algo ao beneficiário da ação, que no caso são os rapazes que trabalham com certo senhor. Esse clítico parece apresentar uma conotação de posse, pois é possível fazer a sua substituição por a escola deles. Em PB tal interpretação semântica e sintática seria possível, pois poderíamos arriscar a construção: Tenho que pagar a escola deles ao diretor.

(64) Conheço mais ou menos os nomes de, de... das comidas, conheço, não é verdade, explico-Ihe... (inq.41)

Em (64), o verbo explicar é um ditransitivo com interpretação semântica de transferência verbal.Sua grelha temática exige três argumentos: um argumento externo, entidade humana, que transmite ao argumento interno objeto indireto semanticamente interpretado como recipiente, um conhecimento ou uma percepção. O que vai ser transmitido, ou seja, o conhecimento (o tema) não está realizado fonologicamente, trata-se de um objeto nulo recuperado no contexto (as comidas).

(65) E eu disse-lhes assim: «então como é? Domingo é que eu vou ter folga, vós ides cozinhar... (inq. 75)

A sentença em (65) realiza-se com um verbo dizer considerado semanticamente de transferência verbal ou perceptual. Em tais verbos, o argumento externo (sujeito) transfere ao argumento interno objeto indireto (recipiente) certo conhecimento, certa idéia ou percepção, que se acha contida no argumento interno (objeto direto), motivo por que tanto o argumento externo como o interno (objeto indireto) envolvidos no processo são sempre [+animados]. A sentença em (65) corrobora a idéia, já apontada no início do capítulo, de que os clíticos de terceira 
pessoa fazem parte da competência gramatical dos falantes do PE, uma vez que a entrevistada é analfabeta.

...e ao depois ele dizia sempre que eu que nunca era mulher para ganhar um tostão. e eu dizia-Ihe a ele: «não tenhas medo que eu também não...( inq. 839)

A sentença em (66) realiza-se com verbo considerado semanticamente de transferência verbal ou perceptual, ou seja, verbos que têm um argumento externo agente, um argumento interno com papel semântico tema (objeto direto), e um argumento interno PP (ou a-DP) (objeto indireto), com papel temático de recipiente. Em tais verbos, o argumento externo sujeito (agente) transfere ao argumento interno objeto indireto (recipiente) um certo conhecimento, uma certa idéia ou percepção que se acha contida no argumento interno objeto direto (tema), motivo por que tanto o argumento externo como o interno (objeto indireto) envolvidos no processo devem ter um caráter [+animado] que viabiliza não só a transferência mas também a recepção de tais conhecimentos ou percepções. Vale ressaltar que nesta sentença, ocorre o redobro do clítico (diazia-lhe a ele), recurso ainda em uso em PE, muito produtivo em espanhol, mas em desuso em PB. Segundo Tores Morais, 2006), esse clítico redobrado tem uma função de núcleo no PE, tal qual como no espanhol e é considerado como a realização lexical do núcleo aplicativo, como no espanhol.

Importa relembrar que segundo a proposta de Cuervo (2003), mencionada por Torres Morais (2006) já referida neste estudo no capítulo 2, o redobro do clítico permite considerar-se o espanhol como uma língua de construção de objeto duplo, - que possibilita a sua inserção no conjunto das línguas que apresentam a realização do núcleo aplicativo. Torres Morais (2006) propõe também a inserção do PE entre as línguas que possuem a realização do núcleo aplicativo, mas,incluindo outra alternativa, , uma vez que o PE, além de realizar de forma muito reduzida o 
redobro do clítico, faz restrições quanto ao seu uso em relação aos sintagmas nominais plenos, algo que não se verifica no espanhol.

\subsubsection{Ocorrências de colocação do clítico dativo Ihe em relação aos verbos}

A Tabela 26 demonstra as ocorrências de próclise, ênclise e mesóclise do clítico dativo lhe, bem como as formas verbais em que tais clíticos se realizam. $\mathrm{Na}$ Tabela 27 encontra-se a descrição dos percentuais dessas realizações. Os gráficos 41 e 42 oferecem uma melhor visualização dessas ocorrências e da sua distribuição percentual.

Tabela 26 - Ocorrências do clítico dativo $\underline{\text { lhe }}$, com relação ao verbo, no Português europeu

\begin{tabular}{|c|c|c|c|}
\hline 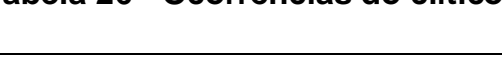 & Próclise & Ênclise & Total \\
\hline verbo finito & 33 & 47 & 80 \\
\hline verbo auxiliar & 13 & 9 & 22 \\
\hline verbo principal & 10 & 16 & 26 \\
\hline Total & 56 & 72 & 128 \\
\hline
\end{tabular}

Fonte: Inquéritos do CRPC

Tabela 27 - Distribuição percentual do clítico dativo $\underline{\text { Ihe, }}$, com relação ao verbo, no Português europeu

\begin{tabular}{|l|r|r|r|}
\hline & \multicolumn{1}{|c|}{ Próclise } & Ênclise & \multicolumn{2}{|c|}{ Total } \\
\hline verbo finito & 25,78 & 36,72 & $\mathbf{6 2 , 5 0}$ \\
\hline verbo auxiliar & 10,16 & 7,03 & $\mathbf{1 7 , 1 9}$ \\
\hline verbo principal & 7,81 & 12,50 & $\mathbf{2 0 , 3 1}$ \\
\hline \multicolumn{1}{|r|}{ Total } & $\mathbf{4 3 , 7 5}$ & $\mathbf{5 6 , 2 5}$ & $\mathbf{1 0 0 , 0 0}$ \\
\hline
\end{tabular}

Fonte: Inquéritos do CRPC 


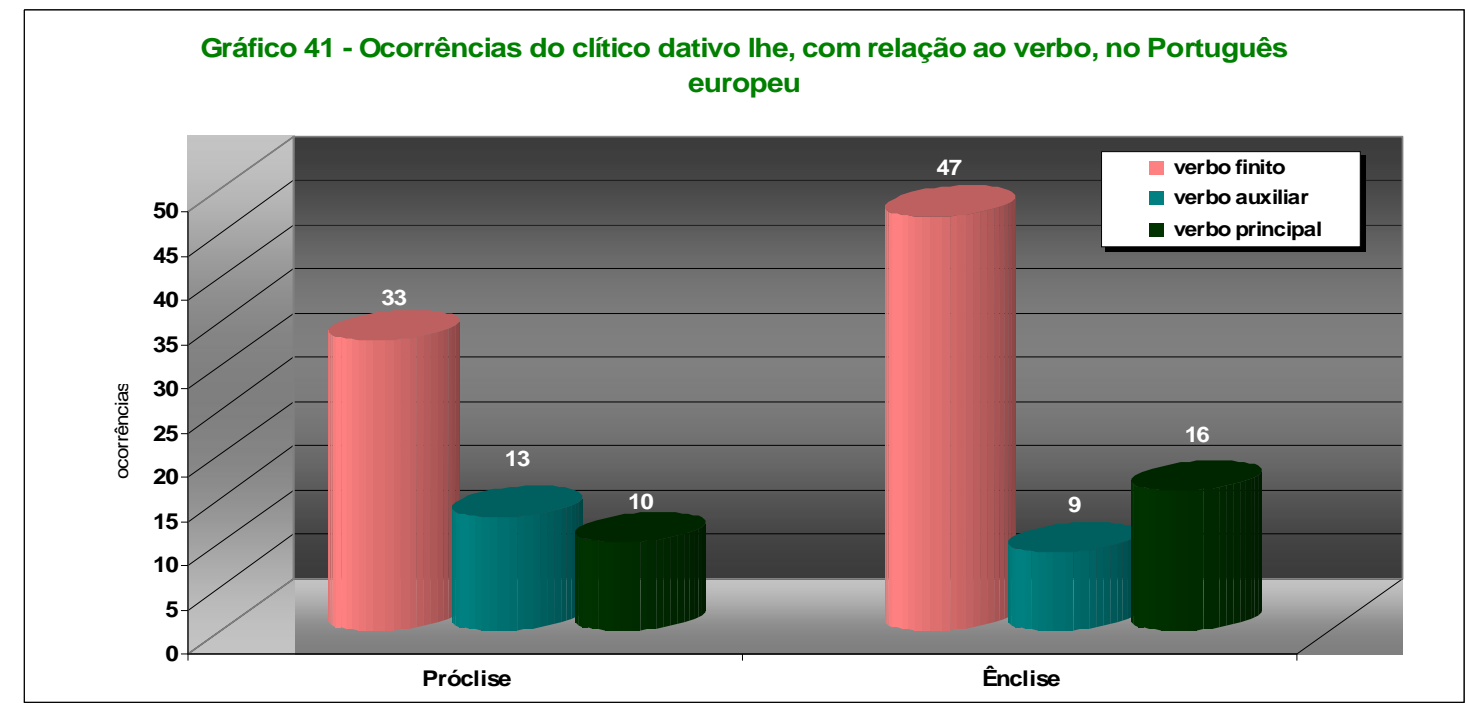

Fonte: Tabela 26

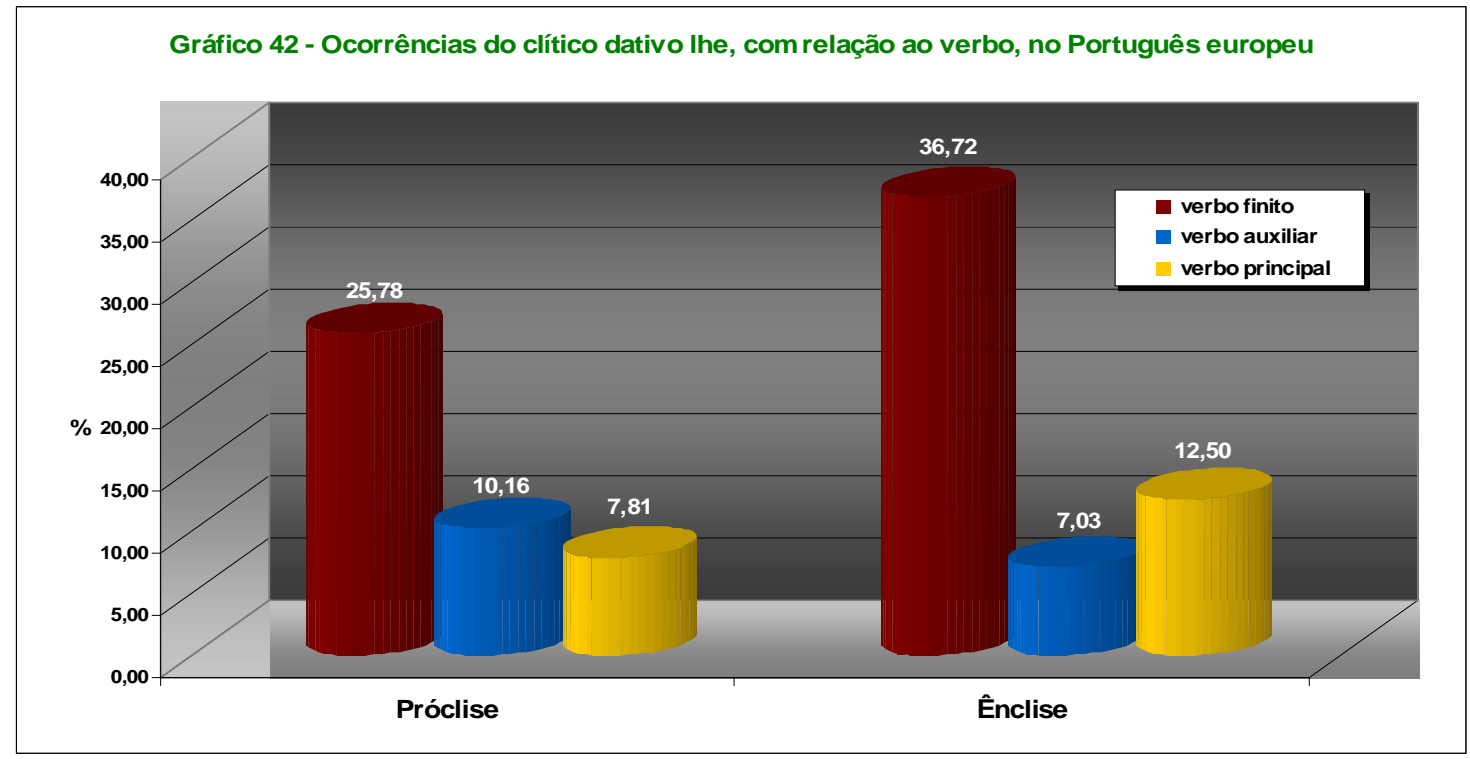

Fonte: Tabela 27

Mateus et al. (2003, p. 856) tecem as seguintes considerações sobre a colocação dos clíticos no PE:

No português moderno, os padrões de colocação dos pronomes clíticos são uma das propriedades sintácticas que distingue as gramáticas de diferentes variedades nacionais da língua portuguesa. 
Comprovamos nesse estudo que existem diferenças consideráveis entre o $\mathrm{PE}$ e o PB em relação à colocação pronominal, especialmente no que se refere à colocação desses clíticos nas locuções verbais.

Mateus et $\operatorname{AL}(2003)$ afirmam, ainda, que a ênclise é o padrão básico, não marcado, e que a próclise ocorre mediante a existência de alguns fatores que a determinam, mas, assinalam as autoras (op. cit.) que as gerações mais jovens tendem a produzir a ênclise mesmo em casos em que a variedade padrão exige a próclise.

A ênclise é a colocação por excelência no PE, talvez por uma obediência à Lei de Tobler Mussafia, já referida no capítulo 3, que proíbe um pronome clítico de aparecer em posição inicial de frase.

A análise das Tabelas 26 e 27 e dos Gráficos 41 e 42 evidencia a preferência do PE pela ênclise, com $36,72 \%$ de ocorrências com o verbo finito, 7,03\% com o verbo auxiliar e $12,50 \%$ de ocorrências com o verbo principal. Isso demonstra uma diferença flagrante com o PB, o qual privilegia a próclise, haja vista que o corpus do PBF analisado tem $100 \%$ de uso da próclise: (68,97\% em relação ao verbo principal e $31,03 \%$ em relação ao verbo auxiliar).

Vale ressaltar que quase todos os casos de próclise no PE $(43,75 \%)$ são justificados, inclusive, pela gramática normativa (negações, conjunções subordinativas, pronomes interrogativos etc.). Já os falantes do PBF não seguem regras para usar a próclise: vão falando e vão colocando o pronome antes do verbo.

Em relação à colocação pronominal, a nossa gramática parece estar mais próxima do espanhol, em que a colocação privilegiada é a próclise. Mas, no espanhol, a ênclise é obrigatória com o infinitivo, o gerúndio e o imperativo, sob pena de a sentença ser considerada agramatical, caso se faça outra colocação. $O$ PBF, ao contrário, não tem amarras, nada tolhe o uso da próclise, a não ser problemas de ordem fonológica que impedem, por exemplo, os clíticos acusativos de iniciarem as sentenças, conforme referido por Nunes (1996, p.209-215). 
(67) X: (...) Outro também uma vez tava muito zangado com o santo porque ue tinha-lhe pedido qualquer coisa e o santo não fez porque nem sempre...(Inq.31)

(68) X: aqui não há nada, nada! Estou-Ihe a dizer, só agora, o que tá a aguentar sesimbra é esses pescadores que andam nesses barcos grandes ( Inq. 764).

(69) X Porque se o senhor não sabe vou-lhe dizer, que é uma das primeiras lotas do país em peixe grosso é esta Sesimbra. (Inq.764)

(70) X: mas também, mas também tenho-lhe dito uma coisa muitas vezes. Senhora dona b conhece-me há meia dúzia de dias, praticamente...(Inq.796)

Os exemplos em (67), (68), (69) e (70) evidenciam o fenômeno referido por Mateus et al. (2003, p 857), como subida do clítico, que consiste na seleção de um verbo do qual o pronome clítico não é dependente, mas hospedeiro verbal.

(71) O de fato macaco não, não , na, embora faça, não Ihe dá jeito fazer ( Inq.290)

(72) $\mathrm{X} E$ ao depois ele só dizia que eu não, que eu não aprendia a cozinhar. E eu disse, e eu só Ihe respondi... (Inq.839).

Nos exemplos em (71) e (72) ocorre próclise nos verbos finitos determinada por fatores que atraem os clíticos:

Os exemplos das sentenças em (73), (74) e (75) demonstram as seguintes situações em relação à colocação pronominal:

(73) O homenzinho vinha em sentido contrário, estava a dar-lhe o sol nos olhos, despistou-se e veio-me cair em cima do capot, (Inq.109).

(74) X: já não sabe! Tou fartinha de Ihe dizer. Ouça (376) 
Em (73) ocorre uma locução verbal em que o verbo principal está no infinitivo não flexionado. Existe na sentença a preposição $a$, mas essa não é elemento que justifique a próclise, então a ênclise é a colocação exata nos moldes do PE

Em (74) há a presença da preposição para que viabiliza a colocação da próclise na ocorrência de um infinitivo não flexionado. Esse fato ocorre com todas as preposições, com exceção de a, segundo informa Mateus et al. (2003, p.865,866) Vale ressaltar que esses contextos admitem também a realização da ênclise.

Em (75), a ocorrência da ênclise ao verbo no infinitivo seria substituída no PB pela próclise ao auxiliar, como se observa em (78).

(76) eu disse-lhes assim:" então como é? Domingo é que eu vou ter folga, vos ides cozinhar (Inq.75)

(77) Eu preguei-lhe um enxerto na porrada..( Inq.482).

(78) A isso eu ia lhe perguntar. (sentença reconstruída em PB)

(79) Eu me calei.( Exemplo da gramática normativa de Cunha \& Cintra), aqui renumerado.

As sentenças em (76), (77) e (78) seriam sempre construídas com o pronome proclítico ao verbo no $\mathrm{PB}$, mesmo por falantes da variedade padrão e talvez até em textos escritos. Cunha (2001, p. 309) dá como exemplo de colocação pronominal adequada no PB, a sentença em em (79)

Neste capítulo, descrevemos as várias formas de realização de dativo no PE e observamos fatos interessantes sobre essas ocorrências. Constatamos emprego da preposição para introduzindo argumentos dativos (poucos casos) tanto com verbos de transferência material, como com verbos de transferência verbal. Se considerarmos que, segundo Mateus et al (2003) e Torres Morais (2007), o que 
caracteriza o dativo no PE é a preposição dummy ${ }^{43}$ a, estamos nesses casos, diante de um PP ou de um desvio da língua (construção agramatical) observada em alguns dialetos e, que não fazem uso do padrão do PE.

Em relação à colocação pronominal, o corpus seguiu o que se espera do $\mathrm{PE}$ : o uso da ênclise na maioria das construções e a realização da próclise na presença de elementos que a determinam. As colocações dos clíticos nos tempos compostos soa bem estranha a nós brasileiros, acostumados que estamos a colocar o pronome antes do verbo principal.

Outro fato merecedor de destaque é o uso dos complementos nulos quase equiparados ao do clítico dativo de terceira pessoa. (não averiguamos se todos os nulos obedecem às regras impostas às suas construções pelo $P E)$ porque se assim não for, tais realizações serão consideradas agramaticais no PE.

Observamos também os contextos oracionais em que ocorreram alguns dos fenômenos estudados. Comprovamos as formas de realização da colocação pronominal em face de verbos finitos e não finitos. Vimos também a insignificante realização dos pronomes tônicos anafóricos preposicionados, que segundo Torres Morais (2006) é uma das maiores diferenças entre o PE e o PB, já que no PB essa é uma estratégia bem produtiva para substituição do clítico lhe, enquanto no PE só se encontram tais formas no redobro do clítico ou em outros contextos específicos e, introduzidos pela preposição $a$.

\footnotetext{
${ }^{43}$ É uma preposição, cujo objetivo é marcar, em nosso estudo, Caso dativo. Não apresenta interpretação semântica.
} 


\section{CONCLUSÃO}

Depois de concluída a pesquisa e analisados os resultados encontrados, constatamos que os falantes do PBF usam todas as inovações que permeiam a fala dos brasileiros, em maior ou em menor escala, confirmando resultados de estudos realizados, já analisados por um número considerável de estudiosos, como Nunes (1993), Câmara Júnior (2004), Duarte (1989), Monteiro (1994), Scher (1996), Cyrino (1999).

Essas inovações vão levando cada vez mais ao distanciamento dos nossos falares dos falares lusitanos, cujas regras são descritas exaustivamente nas nossas gramáticas normativas.

Se nós nos distanciamos tanto do PE nos aspectos fonológicos e lexicais, a ponto de se tornar difícil a comunicação com falantes dessa variedade lingüística, é de se esperar que tais diferenças também ocorram no domínio da morfossintaxe.

Muitas das ocorrências verificadas na pesquisa confirmam a idéia de que os falantes do PE e do PB possuem competências gramaticais distintas.

Em relação ao uso dos complementos dativos de terceira pessoa em suas várias formas de representação no PBF e no CRPC, em verbos ditransitivos de transferência material e transferência verbal, verificamos algumas oposições: o clítico the no PBF apresentou realização insignificante, pois foram encontradas somente três sentenças com tal uso. Em relação às estratégias de substituição desse clítico, a forma mais usada foi o complemento nulo, com $75 \%$ das realizações. O português europeu também usou o complemento nulo para substituir os clíticos, e embora os clíticos tenham tido realização expressiva, foi superada pelo uso dos nulos.

Outro fato a considerar é que os falantes do PORCUIFORT utilizam o pronome ele na função de objeto direto, o que não se verificou no PE. É de se notar que uma das maiores diferenças entre as duas variedades encontra-se na colocação pronominal. No corpus do PB houve $100 \%$ de realização de próclise, enquanto no PE houve o equilíbrio entre a próclise e a ênclise, sendo a primeira usada geralmente quando havia algo que justificasse seu uso. 
Uma das estratégias do PB de substituição dos clíticos dativos foi o uso dos pronomes tônicos anafóricos ele(s) ela(s), antecedidos da preposição a ou para. Essa estratégia teve uma realização de $7,75 \%$ em todo o corpus do PB. No PE, essa realização foi praticamente zero, pois tais formas só podem ser realizadas em contextos específicos. O que podemos ressaltar em relação ao uso dos anafóricos preposicionados no PORCUFORT é que o percentual de $7,75 \%$ de realização foi inferior à terça parte do que se observou na fala dos jovens curitibanos (Berlinck, 2001)

Outro aspecto que se destacou em nossa pesquisa foi o uso da preposição introdutora do argumento dativo. Embora no PB tenha havido maior realização de dativos introduzidos pela preposição para, a preposição a apresentou realização considerável: $45,66 \%$ das 173 realizações com preposição no PB ocorreram com a preposição para, enquanto a preposição a apresentou percentual de 41,61\%.

No PB encontramos também $9,82 \%$ de dativos introduzidos sem auxílio de preposição, ou seja, construções de objeto duplo, que configura o núcleo aplicativo no PB aos moldes do inglês, segundo Torres Morais e Salles (2007). Essa realização considerada expressiva na fala do fortalezense culto não nos anima a imaginar que nesse contexto geográfico existam as construções dativas que viabilizariam inserir o PBF como uma variedade do PB que exibe as condições de apresentar argumentos aplicados. Sabemos que tal fato não ocorre porque, como já frisamos no segundo capítulo, através da fala das crianças de Fortaleza e, no terceiro capítulo, na descrição e análise das sentenças do PBF, a preposição a desses contextos não pode ser considerada marcador de Caso dativo, uma vez que alterna com o para em todos os contextos, sem que haja nenhuma modificação semântica, sinalizando que a preposição a adquiriu um caráter lexical, ou seja, está introduzindo PPs, aliás, licenciando-os, segundo o enfoque gerativista.

O núcleo aplicativo não pode, então, ser realizado com tais complementos, pelo simples fato de lhes faltar as condições mínimas para sua realização, que é a presença de um a-DP. Como conseqüência da perda dos dativos, os clíticos deixam de existir no PB, pois ocupam no PE posição argumental, estando em distribuição complementar com os aDPs. Se não existe dativo, não existirá clítico referindo-se à 
terceira pessoa. As realizações de clíticos observadas no Porcufort referem-se à segunda pessoa e são usadas na interlocução e correspondem à expressão a você, cf. Galves (2001)

Em PE, a preposição usada com exclusividade na introdução do argumento dativo é a preposição $a$. Tal fato viabiliza a inserção do PE entre as línguas que detêm a capacidade de realização do núcleo aplicativo, cf.proposta de Torres Morais (2006). Verificamos também que o PE apresenta, no contexto estudado, a construção ditransitiva preposicionada, que, embora não fazendo parte da nossa proposta de estudo, foi verificada e comentada, por ser a outra face das construções de objeto duplo (alternância dativa).

A realização dos clíticos dativos de terceira pessoa foi expressiva no PE e quase nula no PBF, sinalizando uma possível mudança em vias de consolidação. Para Galves (2001), a falta de legitimidade dos clíticos de terceira pessoa como núcleo traz implicância com relação à colocação pronominal, inviabilizando a ênclise, pois esta surge com o movimento do verbo e, conseqüentemente, do clítico para uma posição mais alta que AGR, que seria COMP. Como os verbos no PB não chegam a AGR, detendo-se em T, por causa da concordância fraca, não se realiza a subida nem do verbo, nem do clítico. Já no PE, a sua concordância forte viabiliza a subida tanto do verbo como do clítico a uma categoria superior no caso, COMP. Tal fato justifica a freqüência com que a ênclise se realiza no $\mathrm{PE}$, sendo, segundo Mateus et al. (3003), a colocação pronominal padrão no PE.

Por tudo isso, podemos concluir que as competências gramaticais dos falantes do PE e do PBF são distintas, considerando-se como competência gramatical a sugerida por Galves (2001) que tem a ver com a fixação de parâmetros da gramática universal.

Todas essas constatações a respeito das diferenças entre o PE e PBF podem ter também uma repercussão positiva para os nossos professores que estão nas salas de aula. Ou seja, a de que a tarefa de familiarizar os alunos com os fatos das normas urbanas de prestígio, em uso na fala e escrita dos brasileiros escolarizados é de grande valia. Não é na gramática tradicional que se encontra o apoio para esta tarefa. A gramática tradicional, de cunho normativo, valoriza a língua escrita dos 
escritores, escolhidos a priori como aqueles que mais de perto servem para ilustrar os padrões dos usos cultos lusitanos. 


\section{REFERÊNCIAS BIBLIOGRÁFICAS}

ARAGÃO, M.S.S. \& SOARES, M.E. Org (1996) Projeto Dialetos Sociais

Cearenses- A Linguagem Falada em Fortaleza. Fortaleza. Imprensa

Universitária. Universidade Federal do Ceará.

BAGNO, M. (2004) Português ou brasileiro? Um convite à pesquisa. São Paulo, ed. Parábola. Pág.173-174

BANDEIRA, M. (1970) Estrela da vida inteira: poesias reunidas. Rio de Janeiro, José Olympio/INL, p. 331).

BECHARA, E. (2003) Moderna gramática portuguesa. Ed. rev. e ampl. Rio de Janeiro, Lucerna. Pág 421-423

BECHARA, E. (2005) Lições de Português pela análise sintática. 17ª̣. ed. rev. e ampl. Rio de Janeiro, Lucerna. p.39

BENVENISTE, E. (1976) Problemas de lingüística geral. ed. São Paulo, Ed.

Nacional. p.283

BERLINCK, R. (1996) The dative. In: VAN BELLE, W. \& VAN LANGENDOMCK, W. (org.) Case and grammatical relations across languages. Amsterdan, John Benjamins Publ.Co. (V.1: Descriptive studies)

BERLINCK , R.(1999) O objeto indireto no portugués brasileiro do séc. XIX . IN: CONGRESSO NACIONAL DA ABRALIN, 2. Anais. Florianópolis, 2000.

BOSQUE, I. \& DEMONTE, V (1999).Gramática Descriptiva de la Lengua

Española 2: Las construcciones sintácticas fundamentales. Relaciones. temporales, aspectauales y modales. Madrid, Real Academia Espanhola. P.1861-72.

CÂMARA JR., J. M. (1972). Dispersos. Rio de Janeiro, FGV/ Instituto de Documentação.

CÂMARA JR. J. M. (1980). Princípios de lingüística geral. Rio de Janeiro, Ed. Padrão.

CÂMARA JR., J. M. (2004) Dispersos; org. por C.E.F. Uchoa. Rio de Janeiro, Lucerna. p. 96.

CASTILHO, A.T. (2005). Estudos de Língua Falada: uma entrevista com Ataliba Teixeira de Castilho. Revista Virtual de Estudos da Linguagem - ReVEL. Ano 
3, n.4,março de 2005. ISSN1678-8931.

[http://paginas.terra.com.br/educacao/revel/index.htm].

CUNHA, C. \& CINTRA, L.F. (2001) Nova gramática do Português contemporâneo. Rio de Janeiro, Nova Fronteira.

CYRINO, S.M.L. (1999) Elementos nulos pós-verbais no Português brasileiro contemporâneo. 2a ${ }^{\text {a }}$ ed. São Paulo; Campinas, Humanitas/FFLCH/USP; Ed. Unicamp.

DELLINGER, M. et al. (2002) Padrões de complementação no português falado. In: KATO, M. A. (2002) (org) Gramática do Português Falado; vol. 5: convergências. Campinas, Ed. Da Unicamp. p. 28.

DICIONÁRIO DE LINGÜÍSTICA, por Jean Dubois et alii. Direção e coordenação geral de tradução de Izidoro Blikstein. São Paulo, Cultrix, 2004.

DRUMMOND DE ANDRADE, C. (1974) Dez livros de poesia: reunião. Rio de Janeiro, José Olympio. p.12

DUARTE, M. E. L. (1986) Variação e sintaxe: clítico acusativo, pronome lexical e categoria vazia no Português do Brasil. São Paulo, PUC/SP. (Dissertação de mestrado)

DUARTE, M. E. (1989) Clítico acusativo, pronome lexical e categoria vazia no Português do Brasil. In: TARALLO, F. (org.) Fotografias Sociolingüísticas. Pontes,Campinas, pp.19.

FARIA, E. (1958) Gramática Superior da Língua Latina,Ed. Livraria Acadêmica, Rio de Janeiro (Pag. 62)

FREIRE, G. (2005) A realização do acusativo e do dativo anafóricos de terceira pessoa na escrita brasileira e lusitana. Tese de doutorado. UFRJ, Rio de Janeiro. p.56.

GALVES, G. (2001) Ensaios sobre as gramáticas do Português. Campinas, Editora Unicamp. (pág.13-14;19; 140; 142; 146)

GALVES, G. \& ABAURRE, M.B.M. Os clíticos do português brasileiro: elementos para uma abordagem sintático-fonológica. In: CASTILHO, A.T. \& BASILIO, M. (2002) (org) Gramática do Português Falad; vol.4: estudos descritivos. Campinas, Ed. Da Unicamp (p. 267). 
HOUAISS, A. (2004) Dicionário Houaiss da língua portuguesa. Rio de Janeiro, Editora Objetiva.

LOBATO, L. (1986) Sintaxe gerativa do Português: da teoria padrão à teoria da regência e ligação. Belo Horizonte, Ed. Vigília. p.29.

LLORACH, E. A. (2003) Gramática de la lengua española. Madrid, Espasa.

LUCCHESI, D. \& ARAUJO, S. (2006) A sociolingüística variacionista: fundamentos teóricos e metodológicos. Consultado no endereço:

http://www.vertentes.ufba.br/socio.htm

MARROQUIM, MARIO.(1945) A língua do Nordeste (Alagoas e Pernambuco). São Paulo: Ed. Nacional. (Prefácio de Gilberto Freyre).

MARTINS, A. M. (2003). Variação e mudança no português; a língua portuguesa.

In: Actas dos IX Cursos Internacionais de Verão de Cascais. Cascais: Câmara Municipal de Cascais e Instituto de Estudos Sociais.

MATEUS, M.H.M. et al. (2003) Gramática da língua portuguesa. Lisboa, Caminho.

MIOTO, C.; FIGUEIREDO SILVA, M.C. \& LOPES, R.E.V. (2005) Novo Manual de Sinaxe. Florianópolis, Ed. Insular.

MOLLICA, M. C. M. \& BRAGA, M. L. (org.) (2003) Introdução à sociolingüística: o tratamento da variação. São Paulo, Contexto.

MOLLICA, M. C. M. \& RONCARATI, C. N. (2001) Questões teórico-descritivas em sociolingüística e em sociolingüística aplicada e uma proposta de agenda de trabalho. Revista DELTA, vol.17, número especial, p.45-55.

MONTEIRO, J. L. (1994) Pronomes pessoais: subsídios para uma gramática do Português do Brasil. . Fortaleza, EUFC. Pág 86-89

NEVES, M. H. (2000) Gramática de usos do Português. São Paulo, Ed. Unesp.

NUNES, J. (1996) Direção de cliticização, objeto nulo e pronome tônico na posição de objeto em português brasileiro. In: ROBERTS I. \& KATO, M. A (orgs.) Português brasileiro: uma viagem diacrônica. Campinas, Unicamp, pp. 207220.

OLIVEIRA, M., (2006) Adjuntos e complementos verbais introduzidos pela preposição 'A'. Acessado em: www.fflch.usp.br/dlcv/iport/moliveira001.pdf 
ORDOÑEZ, S.G. (1999). Los dativos. In: BOSQUE, I. \& DEMONTE, V. (dir.) Gramática descriptiva de la lengua española; v. 2, las construcciones sintácticas fundamentales; relaciones temporales, aspectuales y modales. Madrid, Espasa, p.1860-1876.

PAREDES DA SILVA, V. L. (2003). Relevância das variáveis lingüísticas. In: MOLLICA, M.C. \& BRAGA, M.L. Introdução à sociolingüística: o tratamento da variação. São Paulo, Contexto.

RAPOSO, E. (1978) Teoria da gramática: a faculdade da linguagem. Lisboa, Ed. Caminho.

RAPOSO, E. P. (1998) Teoria da Gramática: a faculdade da linguagem. Lisboa, Ed. Caminho, pp.54-55.

ROBERTS I. \& KATO, M. A (1987) Harmonia transistêmica: variação inter e intralingüística. In: ROBERTS I. \& KATO, M. A (1996) (orgs.) Português brasileiro: uma viagem diacrônica. Campinas, Unicamp. p.16

ROCHA, L (1978) Gramática normativa da língua portuguesa. Rio de Janeiro, José Olympio.

SCHER, A.P.(1996) As Construções com Dois Complementos no Inglês e no Português do Brasil. Dissertação de Mestrado. UNICAMP

SCHERRE, M.M.P.(1993) Introdução ao pacote VARBRUL para microcomputdores. Rio de Janeiro, UFRJ.

SOREANO, O. F (2000) El pronombre personal: Formas y distribuciones. Pronombres átonos y tônicos. In: BOSQUE, I.\& DEMONTE, V. (dir.). Gramática descriptiva de la lengua española; v.1: Sintaxis básica de las clases de palabras. Madrid: Espasa.

TORRES MORAIS, M.A. C. R. (2006). Argumentos dativos: um cenário para o núcleo aplicativo no português europeu. Revista da ABRALIN, vol.5, n.1/2, p.239-266.

TORRES MORAIS, M.A. C. R. \& BERLINCK, R. de A. (2002) Caracterização do objeto indireto no português. Trabalho apresentado no V encontro do PHPB, Ouro Preto.

TORRES MORAIS, M.A.C. R. \& BERLINCK, R.A (2006). "Eu disse pra ele"ou "Disse-lhe a ele": a expressão do dativo nas variedades brasileira e européia do português. São Paulo, Ed. da UNESP.

TORRES MORAIS, M.A.C. R. \& SALLES, M.M.L. (2007) Parametric change in the grammatical encoding of indirect objects in Brazilian Portuguese; paper presented at University of Pittsburgh, march 15/18, 2007. (integra o Projeto para a História do Português Paulista - PHPB)

TORRES MORAIS, M.A.C. R; RIBEIRO, I (2005). Contraste da sintaxe dos clíticos no português europeu e português brasileiro. São Paulo, Linha D'Água, Ed. Humanitas. p. 21-48.

VIEIRA, S. R. (2004) O ensino da colocação pronominal: prescrição e uso. In: VIEIRA, S.R. e BRANDÃO, S.F., (org) Morfossintaxe e ensino de Português: reflexões e propostas. Rio de Janeiro, Faculdade de Letras/UFRJ 
CORPORA UTILIZADOS NA PESQUISA

Corpus Referencial do Português Contemporâneo - CRPC (1970-1973)

(Acessível em www.clul.pt/sectores/corpusoralpfpublicadozip

Corpus do Português Oral Culto de Fortaleza PORCUFORT (1994). Coordenado por José Lemos Monteiro, UECE, Fortaleza. www.geocities.com/jolemos.geo/ 